\title{
Archeological and Geomorphological Investigations at Prehistoric Sites 41WY50 and 41WY60, Willacy County, Texas
}

Karl W. Kibler

Cross Timbers Geoarcheological Services

Follow this and additional works at: https://scholarworks.sfasu.edu/ita

Part of the American Material Culture Commons, Archaeological Anthropology Commons, Environmental Studies Commons, Other American Studies Commons, Other Arts and Humanities Commons, Other History of Art, Architecture, and Archaeology Commons, and the United States History Commons

Tell us how this article helped you.

This Article is brought to you for free and open access by the Center for Regional Heritage Research at SFA ScholarWorks. It has been accepted for inclusion in Index of Texas Archaeology: Open Access Gray Literature from the Lone Star State by an authorized editor of SFA ScholarWorks. For more information, please contact cdsscholarworks@sfasu.edu. 
Archeological and Geomorphological Investigations at Prehistoric Sites 41 WY50 and 41WY60, Willacy County, Texas

\section{Creative Commons License}

\section{(c) (1) $\Theta(9$}

This work is licensed under a Creative Commons Attribution-NonCommercial-No Derivative Works 4.0 International License. 


\section{ARCHEOLOGICAL AND GEOMORPHOLOGICAL INVESTIGATIONS AT PREHISTORIC SITES \\ 41WY50 AND 41WY60,}

\section{WILLACY COUNTY, TEXAS}

Prewitt and Associates, lne.

Consulting Archeologisto

7701 N. Lamar, Suite 104

Austin, Texas 78758

(5.12) 4593349

by

Karl W. Kibler

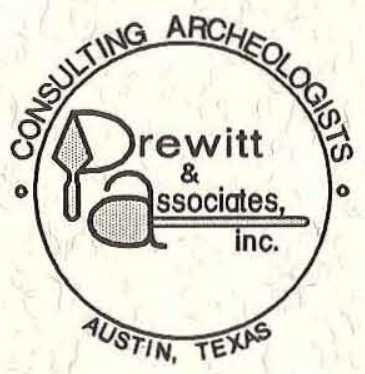




\title{
ARCHEOLOGICAL AND GEOMORPHOLOGICAL INVESTIGATIONS AT PREHISTORIC SITES 41WY50 AND 41WY60, WILLACY COUNTY, TEXAS
}

by

\author{
Karl W. Kibler \\ with Contributions by \\ J. Philip Dering \\ Paul Goldberg \\ and \\ James W. Westgate
}

Co-Principal Investigators: Elton R. Prewitt and Steve A. Tomka

REPORTS OF INVESTIGATIONS, NUMBER 95

Prewitt and Associates, Inc.

Consulting Archeologists

Austin, Texas

March 1994 


\section{TABLE OF CONTENTS}

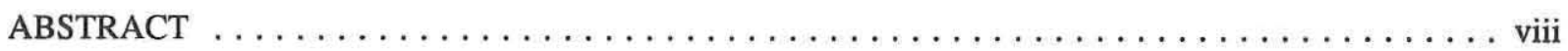

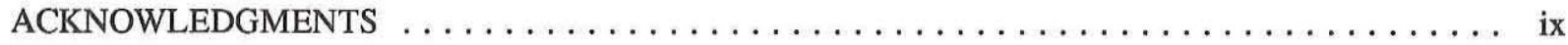

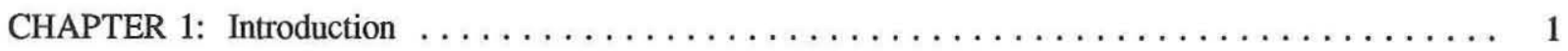

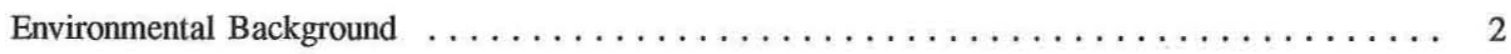

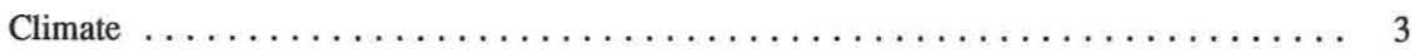

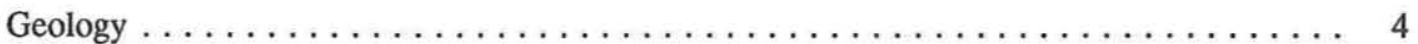

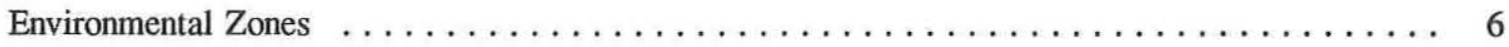

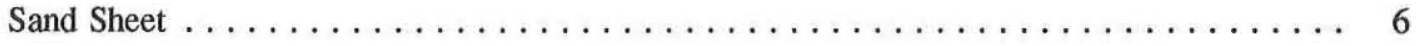

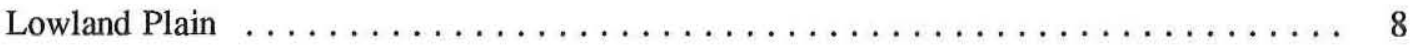

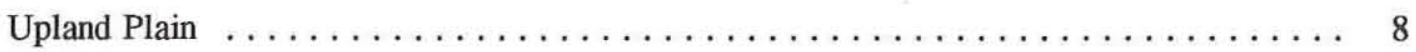

Rio Grande Floodplain and Delta $\ldots \ldots \ldots \ldots \ldots \ldots \ldots \ldots \ldots \ldots \ldots \ldots \ldots \ldots \ldots \ldots \ldots \ldots \ldots$

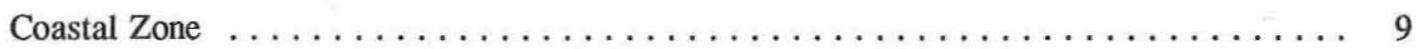

Geology and Holocene Geomorphology . . . . . . . . . . . . . . . . 9

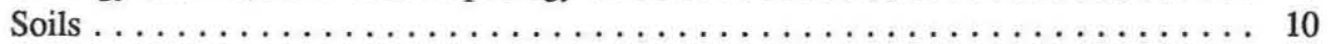

Fauna and Flora $\ldots \ldots \ldots \ldots \ldots \ldots \ldots \ldots \ldots \ldots \ldots \ldots \ldots \ldots \ldots \ldots \ldots \ldots \ldots \ldots$

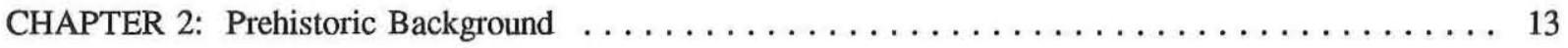

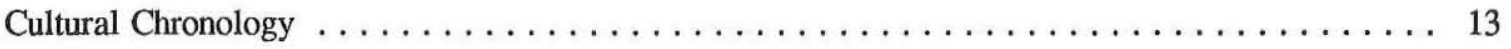

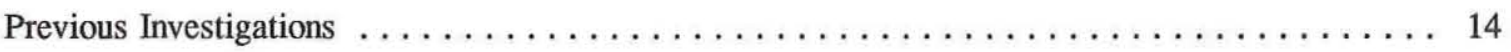

CHAPTER 3: Objectives and Methods of Investigations $\ldots \ldots \ldots \ldots \ldots \ldots \ldots \ldots \ldots \ldots$

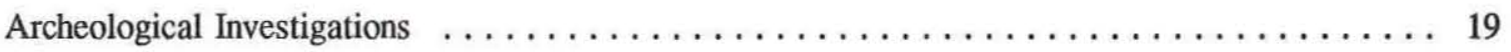

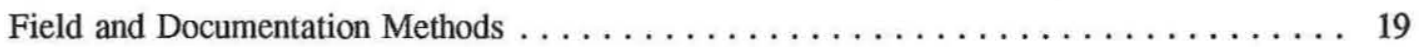

Feature Designation, Documentation, and Excavation $\ldots \ldots \ldots \ldots \ldots \ldots \ldots \ldots \ldots \ldots \ldots \ldots$

Geomorphological and Paleoenvironmental Investigations $\ldots \ldots \ldots \ldots \ldots \ldots \ldots \ldots \ldots \ldots$

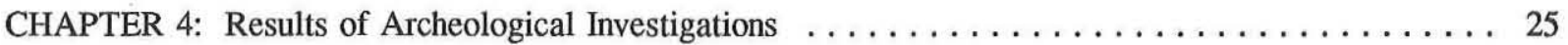

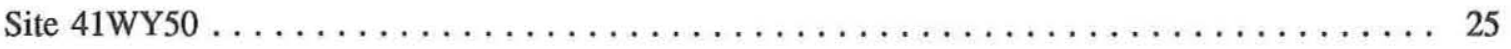

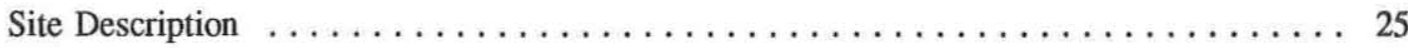

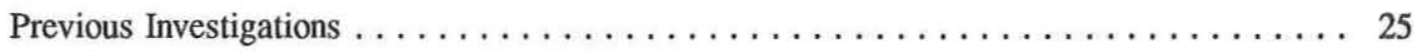

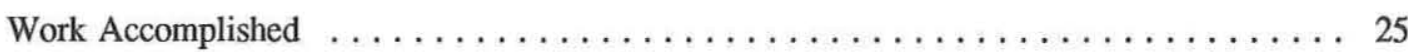

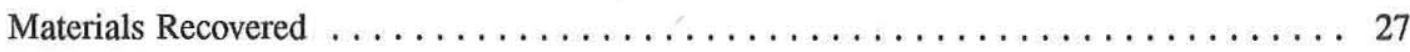

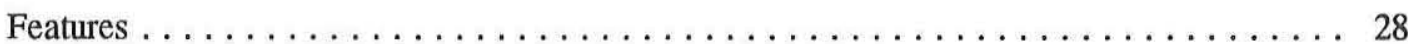

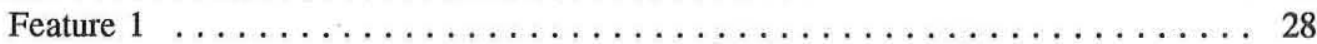

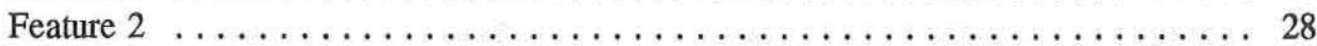

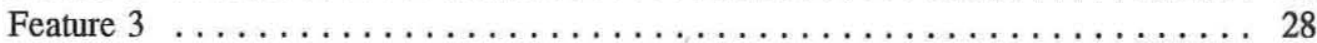

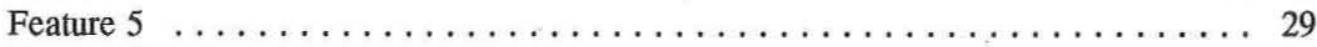

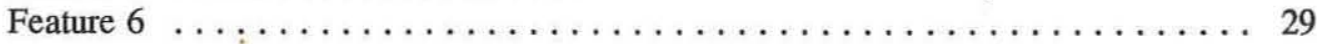

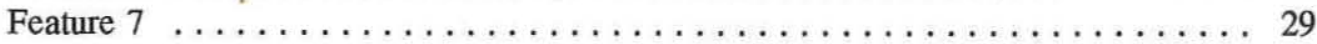

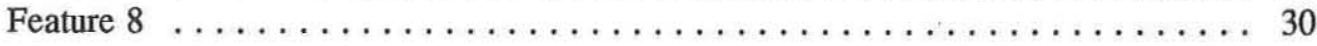




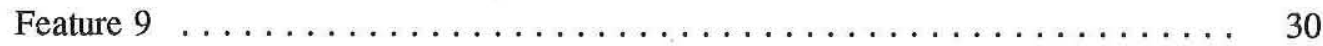

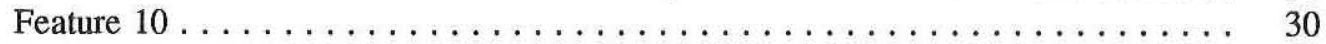

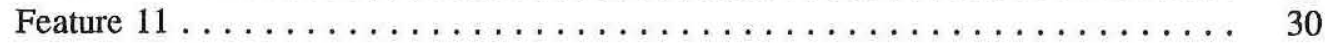

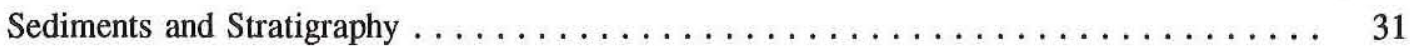

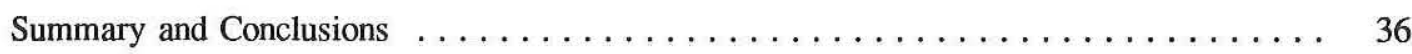

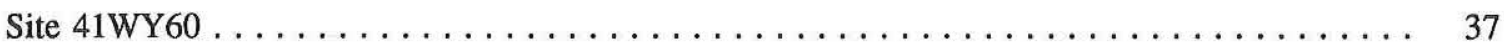

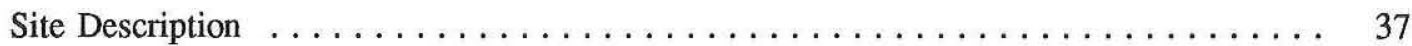

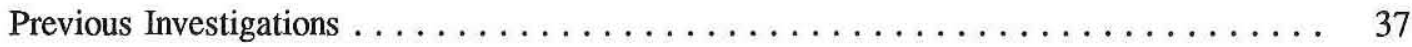

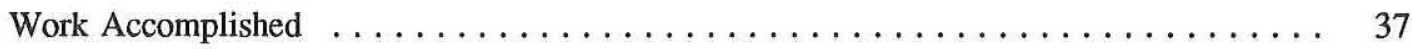

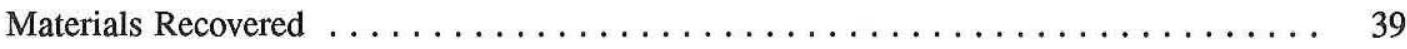

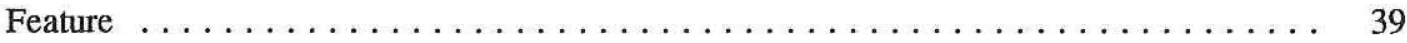

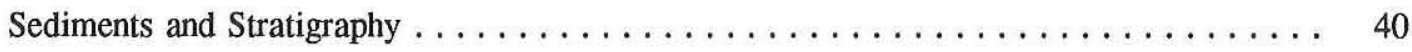

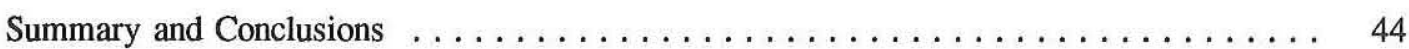

CHAPTER 5: Results of Geomorphological and Paleoenvironmental Investigations $\ldots \ldots \ldots \ldots 4$

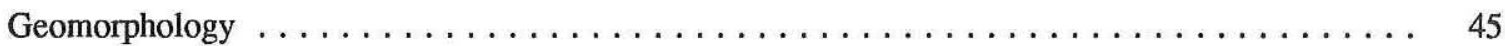

Clay Dune Formation and Sedimentology $\ldots \ldots \ldots \ldots \ldots \ldots \ldots \ldots \ldots \ldots \ldots$

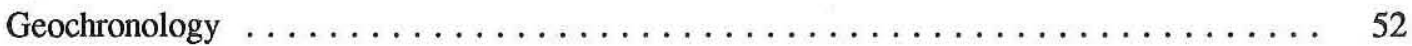

Evidence of a Late Holocene High Sea Stand $\ldots \ldots \ldots \ldots \ldots \ldots \ldots \ldots \ldots \ldots \ldots$

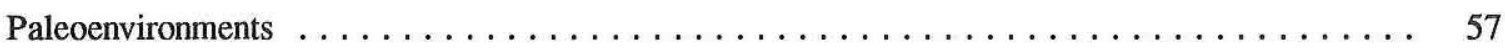

Landscape Stability and Resource Availability $\ldots \ldots \ldots \ldots \ldots \ldots \ldots \ldots \ldots \ldots \ldots \ldots \ldots \ldots \ldots \ldots$

The Archeological Record of the Coastal Zone $\ldots \ldots \ldots \ldots \ldots \ldots \ldots \ldots \ldots \ldots \ldots$

CHAPTER 6: Human Adaptation and the Archeological Record of the Lower Rio Grande Valley: A Review and Assessment for

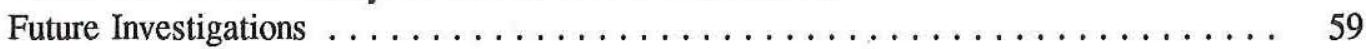

Models of Human Adaptation and Land-Use for the Lower Rio Grande Valley . . . . . . . . . 59

Research Goals and Assessment of the Archeological Record for the Lower Rio Grande Valley $\ldots \ldots \ldots \ldots \ldots \ldots \ldots \ldots \ldots \ldots \ldots \ldots \ldots \ldots \ldots \ldots \ldots$

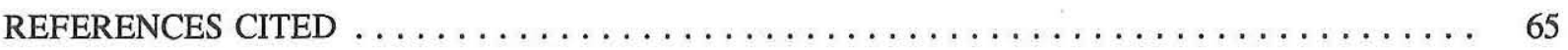

APPENDIX A: Geomorphic Profile Descriptions

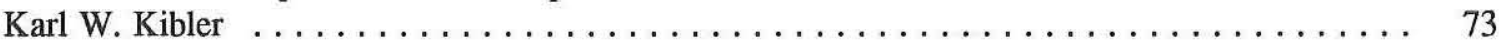

APPENDIX B: Textural and Chemical Analyses of Sediment Samples, 41WY50

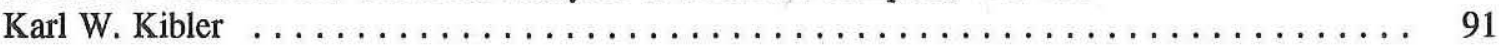

APPENDIX C: Analysis of Vertebrate Faunal Remains from 41WY50 and 41 WY60

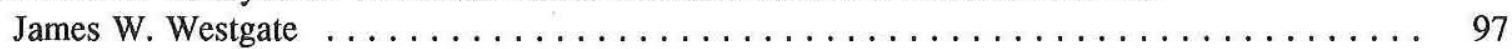

APPENDIX D: Pollen and Phytolith Analysis

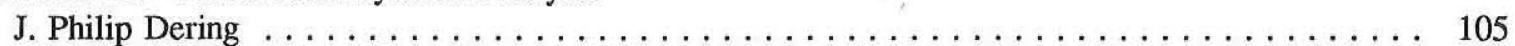

APPENDIX E: Micromorphological Analysis of Features, 41WY50

Karl W. Kibler and Paul Goldberg $\ldots \ldots \ldots \ldots \ldots \ldots \ldots \ldots \ldots \ldots \ldots \ldots \ldots \ldots$ 


\section{LIST OF FIGURES}

1. Willacy County and project location map $\ldots \ldots \ldots \ldots \ldots \ldots \ldots \ldots \ldots \ldots \ldots \ldots \ldots \ldots \ldots \ldots \ldots$

2. Mean monthly temperatures for Brownsville, Raymondville, and McAllen $\ldots \ldots \ldots \ldots$

3. Mean monthly precipitation for Brownsville, Raymondville, and McAllen $\ldots \ldots \ldots \ldots \ldots \ldots$

4. Bedrock geological formations and Holocene landforms

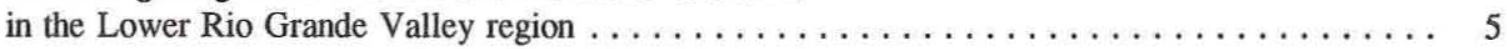

5. Map of environmental zones of the Lower Rio Grande Valley $\ldots \ldots \ldots \ldots \ldots \ldots \ldots \ldots$

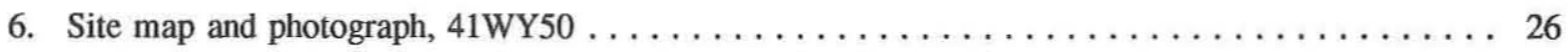

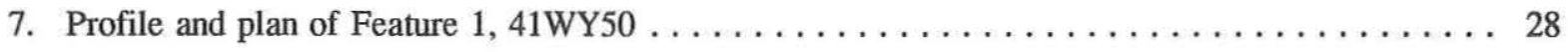

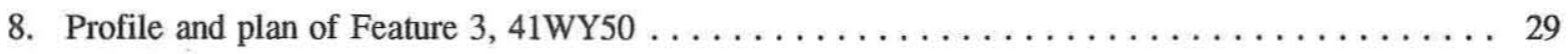

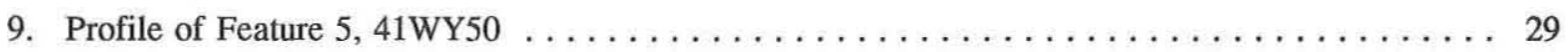

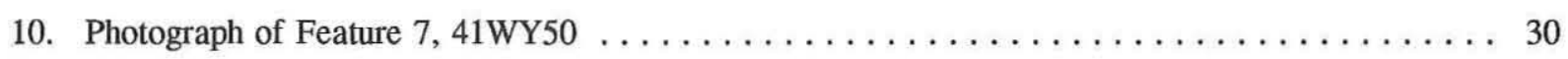

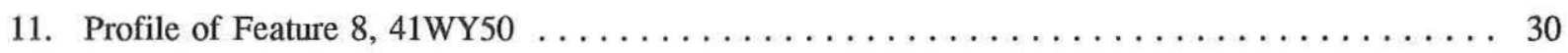

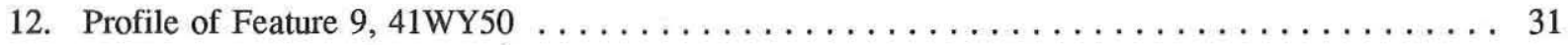

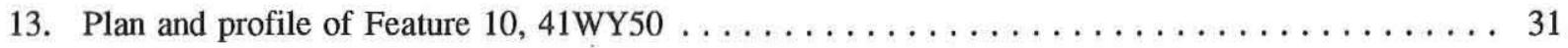

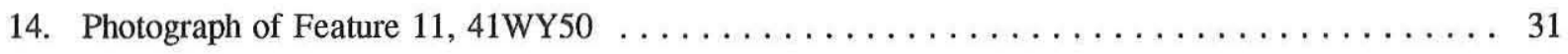

15. Profiles of Backhoe Trenches 2 and 8 and Backhoe Trench Localities

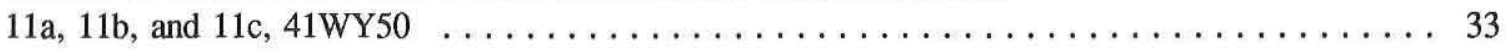

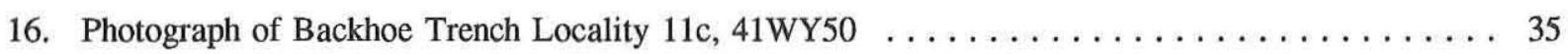

17. Sequence of deposits at $41 \mathrm{WY} 50$ as seen in the profiles of Backhoe Trench Trench Localities 11a, 11b, and 11c and Backhoe Trench $8 \ldots \ldots \ldots \ldots \ldots \ldots \ldots \ldots$

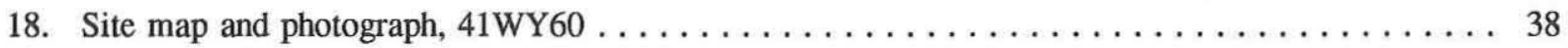

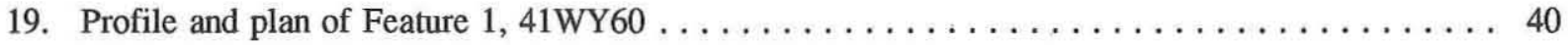

20. Profiles of Backhoe Trenches 8, 9, and 12 and Geomorphic Locality No. 1, 41WY60 . . . . . 42

21. Photograph of north wall of Backhoe Trench 10 showing Beaumont Formation

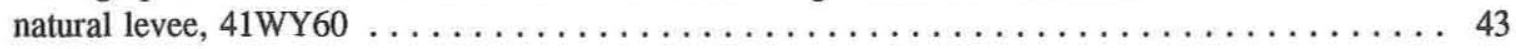

22. Grain-size distributions of wind-tidal flat sediment samples, 41 WY50 $\ldots \ldots \ldots \ldots \ldots \ldots .46$

23. Log probability graphs for wind-tidal flat sediment samples, 41 WY50 $\ldots \ldots \ldots \ldots \ldots$

24. Photograph of desiccation cracks and polygons on wind-tidal flat at 41 WY50 $\ldots \ldots \ldots \ldots 48$

25. Photograph of clay pellets in thin section of sediment sample from 41 WY50 $\ldots \ldots \ldots \ldots .48$

26. Grain-size distributions of selected clay dune sediment samples, 41 WY50 $\ldots \ldots \ldots \ldots \ldots .49$

27. Log probability graphs for selected dune sediment samples from $41 \mathrm{WY} 50 \ldots \ldots \ldots \ldots \ldots \ldots$

28. Sequence of deposits at 41 WY50 showing radiocarbon assays $\ldots \ldots \ldots \ldots \ldots \ldots \ldots \ldots \ldots$

29. Photograph of truncated windward face and escarpment at the 41 WY50 clay dune $\ldots \ldots \ldots \ldots 54$

30. Log probability graph of the $41 \mathrm{WY} 50$ clay dune sediment samples

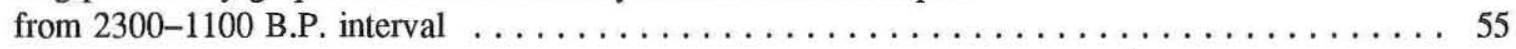


31. Estimates of $C_{3}$ plant percentages from soil humate samples, $41 \mathrm{WY} 50$ and $41 \mathrm{WY} 60 \ldots \ldots \ldots 57$

32. Thin section of Feature 9 sediments showing wood charcoal and underlying

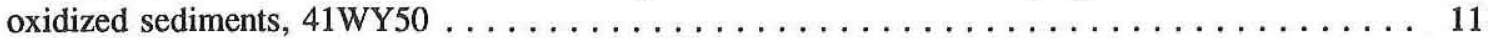

33. Thin section of Feature 10 sediments showing grass charcoal and underlying oxidized sediments, $41 \mathrm{WY} 50$ 


\begin{abstract}
In January through March 1993, archeological and geomorphological investigations were conducted at two clay dune sites, 41WY50 and 41WY60, in the outfall area of the Hidalgo-Willacy Drainage Ditch system. This work represents the final investigations of a cultural resource management program conducted for the U.S. Army Corps of Engineers and the local sponsors, Hidalgo County Drainage District No. 1 and Willacy County Drainage District No. 1, by Prewitt and Associates, Inc.

The results of the archeological investigations were poor. Neither site yielded materials of unquestionable cultural origin, although several small basin-shaped hearth features were encountered. Based on radiocarbon assays from soil humates and the stratigraphic provenience of the features, it is speculated that the occupation(s) at 41WY50 is late Archaic and the occupation(s) at 41 WY60 is Late Prehistoric to Historic. Both sites represent very short term occupations and most likely do not represent repetitive use on a seasonal or yearly basis. These investigations suggest that, since the development of the modern coastal environments approximately 3,000 to 4,000 years ago, the south Texas coast between Baffin Bay and the Holocene delta of the Rio Grande has been a resource-poor and inhospitable area that probably was utilized only sparsely or intermittently.

The geomorphological investigations were more successful, adding valuable data about paleoenvironments and the formation of the modern coastal environments of the Lower Rio Grande Valley. The clay dunes formed through the eolian transport of fine to very fine quartz sand and fine to very fine sand-sized aggregates of clay from adjacent wind-tidal flats during the late Holocene. Stable carbon isotope studies of soil humates suggest that the clay dune plant community was and still is dominated by $\mathrm{C}_{4}$ and/or CAM plants. These investigations also disclosed fluctuations in sea level during the late Holocene. An abandoned wind-tidal flat, encountered at 41WY50, indicates that sea level was at least $1 \mathrm{~m}$ higher than present mean sea level between 2300-1100 B.P.
\end{abstract}




\section{LIST OF TABLES}

1. Faunal remains and pieces of pumice recovered, 41 WY50 $\ldots \ldots \ldots \ldots \ldots \ldots \ldots \ldots \ldots \ldots \ldots$

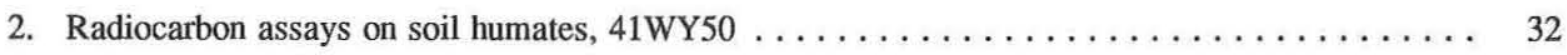

3. Faunal remains and pieces of pumice recovered, $41 \mathrm{WY} 60 \ldots \ldots \ldots \ldots \ldots \ldots \ldots \ldots$

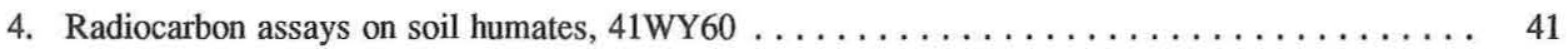

5. Sand percentages of clay dune samples, 41 WY50 $\ldots \ldots \ldots \ldots \ldots \ldots \ldots \ldots \ldots \ldots \ldots \ldots \ldots \ldots \ldots \ldots \ldots$

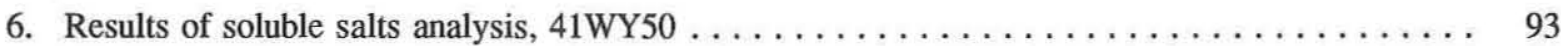

7. Results of sediment grain-size analysis, $41 \mathrm{WY} 50 \ldots \ldots \ldots \ldots \ldots \ldots \ldots \ldots \ldots \ldots \ldots \ldots \ldots \ldots \ldots \ldots$

8. Composite faunal list and preferred Texas habitats $\ldots \ldots \ldots \ldots \ldots \ldots \ldots \ldots \ldots \ldots \ldots \ldots \ldots \ldots \ldots \ldots \ldots \ldots$

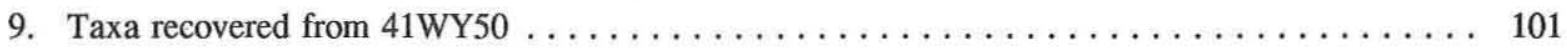

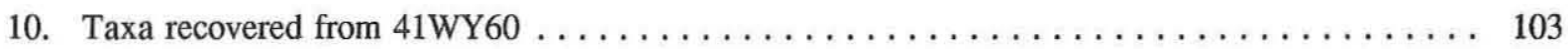




\section{ACKNOWLEDGMENTS}

Many people contributed to the completion of these investigations. El Sauz Ranch supervisor Jerry Taylor graciously provided access to both sites via the El Sauz Ranch roads. Mr. Taylor's helpfulness, cordial personality, and interest in history are greatly appreciated and noted. Representatives of the local sponsors, Vona Walker of the Hidalgo County Drainage District No. 1 and Jim Riggan of the Willacy County Drainage District No. 1, helped obtain access and provided a backhoe and operator. Ernesto Hernandez, a Willacy County Drainage District backhoe operator, was more than helpful excavating trenches, repairing impassable ranch roads, and coordinating access to the sites after several heavy rains. His hard work and friendly personality are duly noted. Carolyn Good Murphy of the U.S. Army Corps of Engineers, Galveston District, took time to visit the sites and gave the author advice and suggestions for this report.

The field crew consisted of David Villarreal, Todd Reynolds, Roman Clem, Leigh Ann Garcia, Tina Leshley, and Wayne Chesser. The commitment and dedication of this crew were first rate, especially when one considers the many days of inclement weather, swarming clouds of DEET-resistant mosquitos, and cabin fever that all endured. The author served as Project Archeologist and Geomorphologist.

Individuals offering assistance and advice to the author include Dr. C. Britt Bousman and Dr. Paul Goldberg of the Texas Archeological Research Laboratory, The University of Texas at Austin, and Dr. Jeffrey G. Paine of the Bureau of Economic Geology, The University of Texas at Austin. Dr. Thomas R. Hester, Director of the Texas Archeological Research Laboratory, provided trace element data for two obsidian flakes recovered from $41 \mathrm{WY} 72$ in 1981 as part of the Texas Obsidian Project. These data were not available for earlier publication and are presented in this report for the first time.

As always, the staff of Prewitt and Associates, Inc. played a vital role in the completion of this project. Elton R. Prewitt and Steve A. Tomka served as Co-Principal Investigators, mapped 41WY50, and provided the author with advice and help throughout the investigations. Wayne Klement helped map 41WY60 and collected hearth and sediment samples for analysis. Ross C. Fields provided help with the sedimentological and statistical analyses. Karen M. Gardner supervised the laboratory processing of materials, while Sandra Hannum skillfully produced the maps and graphs. Linda $\mathrm{N}$. Foster edited and helped produce a much more readable report. 

This report presents the results of the archeological and geomorphological investigations at two prehistoric sites, $41 \mathrm{WY} 50$ and $41 \mathrm{WY} 60$, in Willacy County, Texas. Both sites are located on the mainland coast of the Laguna Madre within the outfall area of the Hidalgo-Willacy Drainage Ditch system constructed by the Hidalgo County Drainage District No. 1 and the Willacy County Drainage District No. 1 to minimize the impact of hurricane-related floodwaters over much of the area (Figure 1).

Sites 41WY50 and 41WY60 were originally recorded by Day et al. (1981) during Phase I work sponsored by the U.S. Army Corps of Engineers in 1980. In 1987, Hall et al. (1987:76-77) recommended that both sites undergo testing to determine their eligibility for listing on the National Register of Historic Places. Although not directly impacted by ditch construction, the outfall area and sites $41 \mathrm{WY} 50$ and $41 \mathrm{WY} 60$ were determined to be in a zone of potential secondary impacts due to discharge from the ditch and channelization of flow debouching into the lagoonal inlet. Since construction of the Main Floodwater Channel and the North Ditch, sedimentation of bayheads and wind/tidal flats and channelized flow are readily noticeable in the outfall area.

In 1992, a work plan was submitted to the Hidalgo County Drainage District No. 1 and Willacy County Drainage District No. 1 for further investigations at 41WY50 and 41WY60. The plan called for 5 weeks of testing to further define site boundaries, determine site integrity, and determine placement of block excavations at both sites. The results of the testing were to be evaluated at the end of the 5-week period, and if favorable, work was to proceed into a 12-week-or-less period of block excavations and data recovery at one or both of the sites.

The archeological test excavations commenced on January 25 and continued to March 10, 1993. Fieldwork was halted a number of times at the beginning of the testing period due to heavy rains and impassable two-track ranch roads; however, the test excavations were completed in approximately 154 person days. At the end of the testing period, it was determined through meetings with representatives of the Hidalgo and Willacy County drainage districts, the U.S. Army Corps of Engineers, and the Texas Historical Commission that further work at 41WY50 and 41WY60 was not warranted due to the extreme paucity of cultural materials.

The results of the 5-week archeological testing and geomorphological investigations are presented in the following chapters. These investigations were conducted under the regulations of the State of Texas Antiquities Code (Texas Natural Resource Code of 1977, Title 9, Chapter 191, VTCS 6145-9) in conformance with Texas Antiquities Committee Permit No. 1199 and under the special conditions of U.S. Army Corps of Engineers Permit No. 11374 issued by the Galveston District Office. The cultural resources are considered under the provisions of 33 CFR 325 , Appendix C; 36 CFR 800; and 36 CFR 36. Authorizing legislation includes the National Historic Preservation Act of 1966, P.L. 89-665, P.L. 96-515 (as amended); Executive Order 11593 (Protection and Enhancement of the Cultural Environment 1971); and the Archeological and Historical Preservation Act of 1974, P.L. 93-291 (as amended).

The remaining portion of Chapter 1 presents 


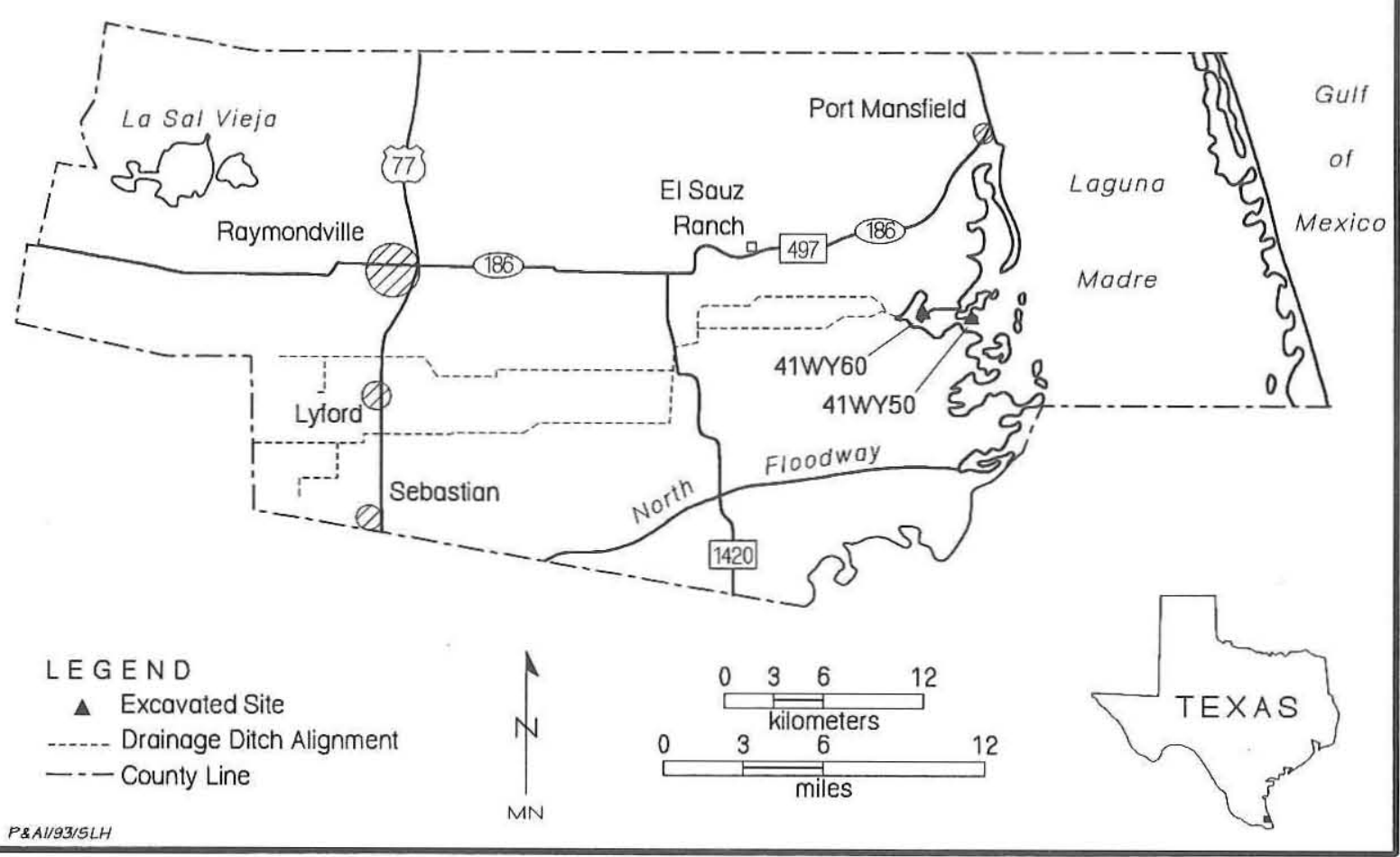

Figure 1. Willacy County and project location map.

environmental background information and a discussion of the different environmental zone designations put forth by Mallouf et al. (1977), Day et al. (1981), Hall et al. (1987), and Bousman et al. (1990), with a particularly detailed discussion of the coastal zone. Chapter 2 presents the cultural chronology and previous archeological investigations in the Lower Rio Grande Valley, along with a review of all cultural resources investigations related to the Hidalgo-Willacy Drainage Ditch system. Chapter 3 presents the methods of investigation that were utilized during the project. Chapter 4 discusses the results of the archeological investigations, while Chapter 5 presents the results of the geomorphological and paleoenvironmental investigations and their geoarcheological and resource-base implications. The final chapter, Chapter 6 , reviews the human adaptation and land-use model proposed by Bousman et al. (1990) and the effects of the present results on that model. New concepts and proposals about human adaptations in the Lower Rio Grande Valley are presented, and the expecta- tions of the archeological record are discussed. Finally, research strategies and goals for future archeological investigations in the Lower Rio Grande Valley are addressed. Five appendixes follow Chapter 6 presenting the methods and data on the geomorphic profiles, sediment textural and chemical analyses, and faunal, pollen, phytolith, and micromorphological analyses.

\section{ENVIRONMENTAL BACKGROUND}

The Lower Rio Grande Valley is characterized by unique climatic conditions, floral communities, and wildlife that combine to form a distinctive ecosystem found nowhere else in the United States (Jahrsdoerfer and Leslie 1988:1). The biotic community, referred to as the Matamoran District of the Tamaulipan biotic province (Blair 1950:103) or the Tamaulipan brushland (Jahrsdoerfer and Leslie 1988), consists mainly of dense thorny brush, which provides food and habitat for many wildlife species. Many neotropical genera of mammals, snakes, lizards, and salamanders reach 
the northern limits of their distributions in the Lower Rio Grande Valley (Blair 1950). The Lower Rio Grande Valley also represents the northernmost extent of 21 bird species that are found in Mexico and Central America (Winckler 1976). The region also provides important feeding, nesting, and cover habitats for many species of migratory birds.

Human impacts on native vegetation have been severe throughout this century and continue to threaten the survival of this unique ecosystem. Since the 1920 s, more than $95 \%$ of the original native vegetation in the Lower Rio Grande Valley has been converted to agricultural or urban use (U.S. Fish and Wildlife Service 1980). More than $90 \%$ of the riparian zone on the United States side of the Rio Grande has been removed (Collins 1984). It is estimated that $98 \%$ of the lush, subtropical region of the delta has been cleared in the United States (U.S. Fish and Wildlife Service 1980) and that a similar percentage has been cleared in Mexico (Collins 1984).

Loss of wildlife habitat through land-clearing activities related to agriculture, ranching, and development has had a profound impact on many animal and plant species. Eighty-six animal species, including the ocelot (Felis pardalis) and jaguarundi (Felis yagouaroundi), are considered endangered, threatened, or placed on notice of review or watch-list by the U.S. Department of the Interior, the State of Texas, or the Texas Organization for Endangered Species (Jahrsdoerfer and Leslie 1988:9, Table 3). Fifty-five plant species also are on the list of endangered, threatened, or watch-list in the Lower Rio Grande Valley (Jahrsdoerfer and Leslie 1988:Table 1).

Land-clearing practices also have had a profound effect on the cultural resources (see Bousman et al. 1990:17-18; Day et al. 1981:170; Mallouf et al. 1977:23-26). The archeological record of the region is characterized as one of sites in disturbed contexts with scattered artifacts.

\section{Climate}

The climate of the Lower Rio Grande Valley is classified as semiarid-subtropical with hot and humid summers and mild winters (Natural Fibers Information Center 1987:16). The region's climate is considered to be one of the most unique in the world (see Norwine and Bingham 1986). Temper- atures are fairly uniform over the entire Lower Rio Grande Valley, although means tend to be a few degrees warmer on the coast than inland during the winter and vice versa in the summer (Figure 2). Modified polar air masses occasionally reach the area during the winter months and interrupt the warm flow of air from the Gulf of Mexico, but the region may go several years without a freeze, especially near the coast.

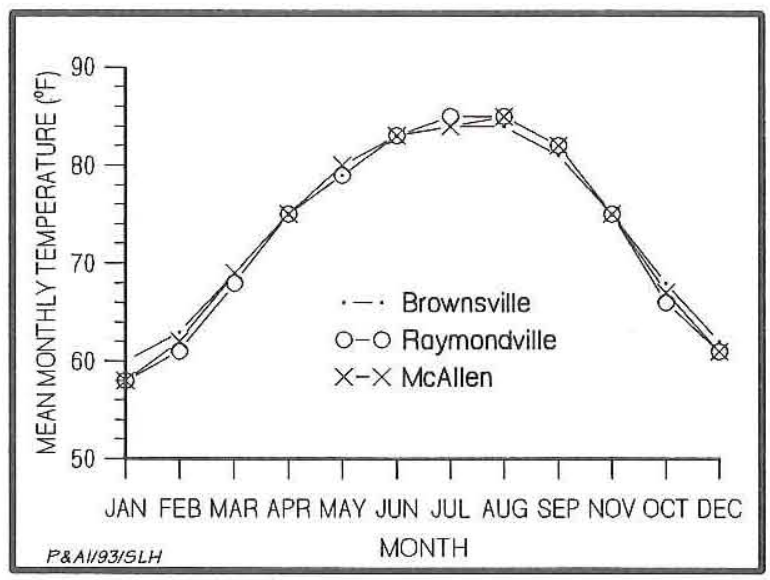

Figure 2. Mean monthly temperatures for Brownsville, Raymondville, and McAllen (data from Natural Fibers Information Center 1987:84, 238, 516).

Although the Lower Rio Grande Valley receives humid air masses from prevailing southeasterly winds from the Gulf of Mexico, the region is semiarid. Precipitation varies across the Valley from about 48.0 to $68.5 \mathrm{~cm}$ a year (Figure 3 ), although it is common for some years to deviate greatly from the mean, especially when hurricanes bring intense rainfall (Natural Fibers Information Center 1987:16; Norwine and Bingham 1986). The effects of the low rainfall are intensified by a high potential evapotranspiration rate of 1,525 mm per year (Norwine and Bingham 1986:3). Cycles of drought have occurred at erratic intervals throughout the twentieth century, with episodes lasting an average of 4 to 7 years (Norwine and Bingham 1986:4). Drought episodes most likely correspond to the frequency of hurricanes, whose absence is a factor in the protraction of drought conditions in south Texas (Bousman et al. 1990:5).

The average relative humidity is high, around $60 \%$ at midday and higher at night (Turner 1982:2). Relative humidity increases during the winter months (Natural Fibers Information Center 1987: 16). 


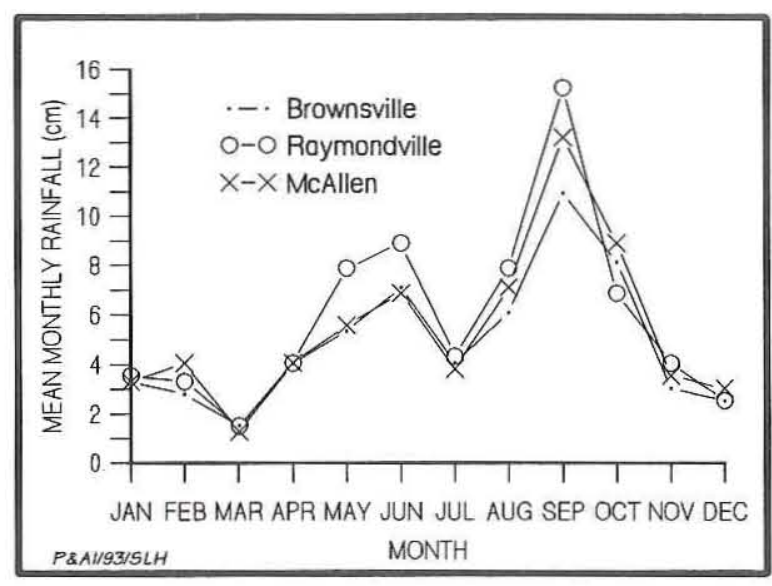

Figure 3. Mean monthly precipitation for Brownsville, Raymondville, and McAllen (data from Natural Fibers Information Center 1987:84, 238, 516).

\section{Geology}

The Lower Rio Grande Valley is part of the West Gulf Coastal Plain section of the Coastal Plain geomorphic province (Hunt 1974:725). The bedrock geology of the province consists of a series of stacked and tilted beds that dip and become progressively younger Gulfward. The Lower Rio Grande Valley is actually a fluvialdeltaic environment consisting mainly of Quaternary channel fill and distributary sands and floodplain and interdistributary muds. Deposition and incision of these sediments have been dictated by cyclical changes in sea level during the Quaternary glacial and interglacial periods (Figure 4).

The earliest deposits in the Lower Rio Grande Valley are Tertiary and are represented by the Goliad Formation, which consists of Pliocene sands, sandstones, marls, and limestones (Barnes 1976). Pleistocene-age deposits consist of fluvial-deltaic sediments of the Lissie and Beaumont formations. The age of these deposits is unclear, although they probably were deposited during the high sea stand of the Sangamon Interglacial period (Brown et al. 1980:17). Morerecent Beaumont Formation deposits are the result of fluvial deposition during a later Pleistocene (Peorian?) interglacial stage (Brown et al. 1980: 18). These more-recent Beaumont Formation deposits formed the Raymondville alluvial plain and its delta in the northern portion of the Lower Rio Grande Valley. The Pleistocene fluvialdeltaic formations consist of meanderbelt sands surrounded by floodbasin muds.

Toward the end of the Pleistocene, climatic and environmental changes led to dramatic developments and the establishment of the modern environments of the Lower Rio Grande Valley. At the peak of the Last Glacial Maximum around 18,000 B.P., sea level dropped significantly and the Rio Grande cut a deep valley into the Beaumont Formation. Irregular rising sea levels during the Holocene caused the valley to fill through meanderbelt (point bar) and floodbasin mud deposition. Basinward, the valley was flooded, forming an estuary. Erosion along the margins of the Rio Grande estuary and valley walls widened the original Pleistocene valley. Tidetransported marine sediments were deposited over the earlier estuarine deposits. Around 10,000 to 7000 B.P., this transgressive period ceased (Brown et al. 1980:19). The estuary eventually filled with estuarine, deltaic, and aggrading fluvial sediments after which at least three different Holocene deltas formed in the open waters of the Gulf of Mexico (Brown et al. 1980:19).

By 4500 B.P., sea level reached its approximate modern level, and the Rio Grande prograded a large, wave-dominated delta into the open Gulf at least $16 \mathrm{~km}$ east of the present shoreline (Brown et al. 1980:20). Due to a decrease in the sediment load of the Rio Grande between 3400 and 1900 B.P., delta progradation ceased and marine transgression, which continues today, commenced (Brown et al. 1980:22). As the last major delta of the Rio Grande subsided and waves reworked its delta-front sand sheet, discontinuous offshore bars eventually merged forming South Padre Island, a sandy peninsula attached to the transgressive Rio Grande delta. The peninsula eventually linked with the offshore barriers of middle and northern Padre Island, and the Laguna Madre was formed between the island chain and the mainland shoreline. South Padre Island and the inner shelf continue to move landward, gradually filling the Laguna Madre with washover fan and eolian sediments. Wind-tidal flats and associated clay dunes along the western margin of the Laguna Madre mark the gradual subsidence and transgression of the Rio Grande deltaic plain (Brown et al. 1980:23).

Farther inland, beyond the influence of estuarine and marine transgression, the Rio Grande Pleistocene valley slowly filled throughout the early and middle Holocene by meanderbelt (point bar) and floodplain deposition (Brown et al. 


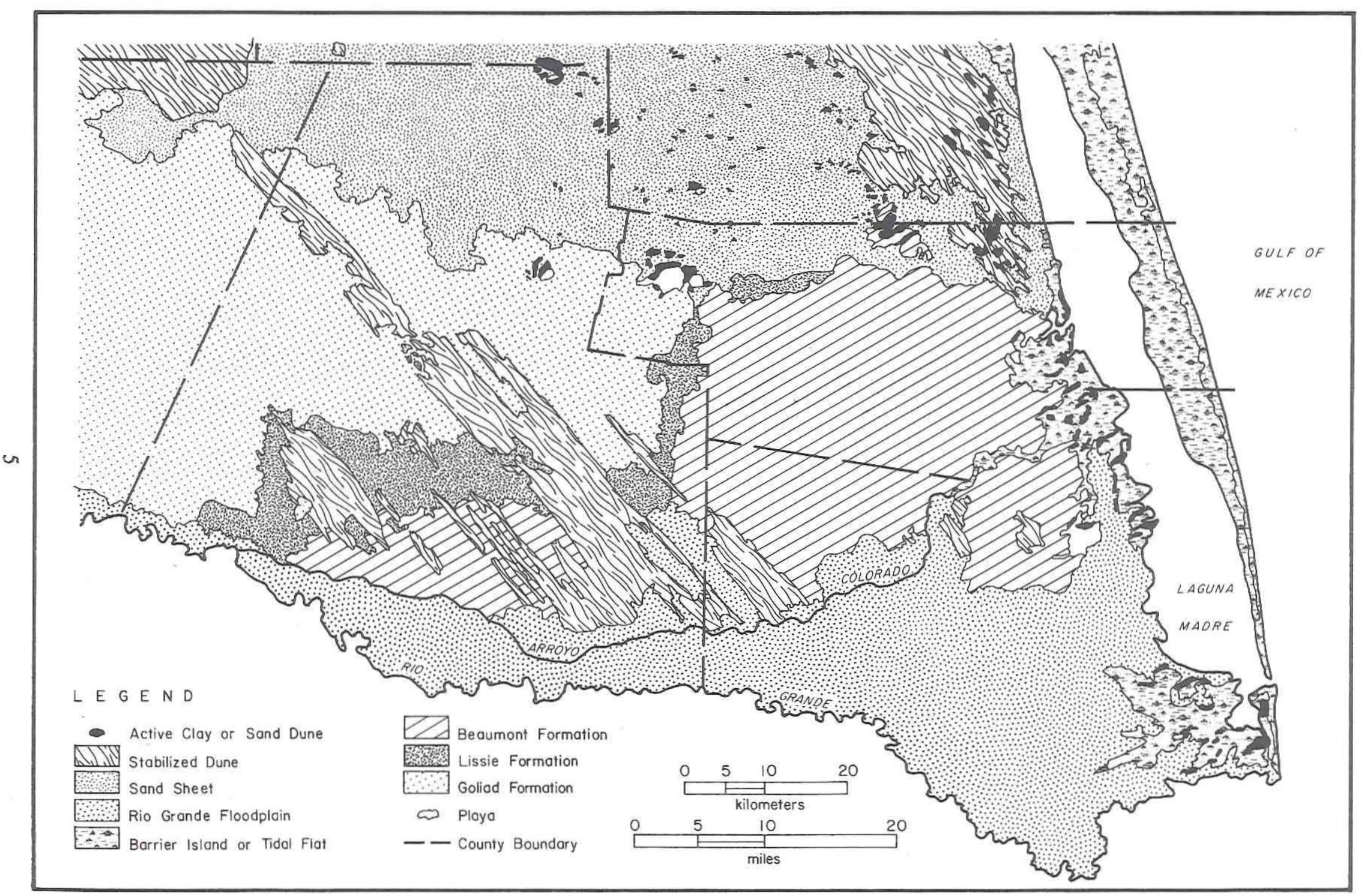

Figure 4. Bedrock geological formations and Holocene landforms in the Lower Rio Grande Valley region (after Bames 1976). 
1980:19). By 4500 B.P., channel incision and terrace formation had occurred (Boyd et al. 1994), possibly triggered by a dwindling sediment supply that culminated between $3400-1900$ B.P. (Brown et al. 1980:22). Continuing decreases in the sediment load of the Rio Grande throughout the late Holocene and the onset of more-xeric climatic conditions (Kibler and Freeman 1993:33; Bousman et al. 1990) has transformed the Rio Grande into an underfit stream within the Pleistocene valley.

Holocene environments of the Rio Grande valley consist of meanderbelt sands and silts, floodbasin muds, distributary sands and silts, interdistributary muds, crevasse splays, abandoned channels and resacas, local marshes, and headward-eroding streams (Brown et al. 1980:56). Most of these environments are inactive or ephemeral, abandoned by the shifting course of the river. Today, only the present Rio Grande channel periodically floods and deposits sediment. Point bar accretion, levee and crevasse splay building, and the flooding of floodbasins and interdistributary areas only occur during periods of heavy rainfalls and run-offs related to tropical storms and hurricanes.

Eolian environments also formed in the Lower Rio Grande Valley at the end of the Pleistocene and throughout the Holocene. Increased aridity during the Holocene resulted in the formation of the south Texas sand sheet and other eolian formations, such as the Faysville-Edinburg stabilized dune field. These eolian deposits and dune trains display southeast-northwest axes, mirroring the modern prevailing wind pattern. Eolian sediments were derived from Pleistocene Lissie and Beaumont formation deltaic and fluvial deposits and were deposited along the northern periphery of the Lower Rio Grande Valley as the south Texas sand sheet. Bousman et al. (1990) produced a series of radiocarbon assays between 12,780 and 4300 B.P. from deflated soils of the Raymondville alluvial plain, suggesting that formation of the sand sheet occurred at this time. It is also suggested that finer materials such as silts were deposited farther inland along the Balcones Escarpment (Bousman et al. 1990:136138).

\section{ENVIRONMENTAL ZONES}

The Lower Rio Grande Valley can be divided into several environmental zones based on different geological, geomorphological, hydrological, topographical, and biotic patterns and characteristics (e.g., Bousman et al. 1990; Brown et al. 1980; Day et al. 1981; Jahrsdoerfer and Leslie 1988; Mallouf et al. 1977). Such divisions were an integral part of some of the initial archeological investigations in the region (e.g. Day et al. 1981; Mallouf et al. 1977). The division of the region into zones was a response to the need for manageable units for sampling cultural resources and for establishing research objectives, which involved predicting site locations according to different environmental/geographical variables. Mallouf et al. (1977:102) divided the Lower Rio Grande Valley into seven environmental zones, based on geographical, topographical, hydrological, and floral characteristics, and to a lesser extent on data believed to be meaningful for the determination of prehistoric land-use patterns and the present archeological record. Ensuing cultural resources investigations by Day et al. (1981) and Hall et al. (1987) fashioned models of environment-site location relationships after Mallouf et al. (1977) with the addition of two more environmental zones that were not part of Mallouf's sampling universe. Later archeological research, focusing on human adaptations in the Lower Rio Grande Valley, used a less-complex set of environmental zones by combining the nine zones into five (Bousman et al. 1990:10-17). The five zones are the sand sheet, the lowland plain, the upland plain, the Rio Grande floodplain and delta, and the coast (Figure 5). These five zones are employed in this report for a discussion and study of human adaptations and resource accessibility and availability (see Chapter 6). Sites $41 \mathrm{WY} 50$ and $41 \mathrm{WY} 60$ are in the coastal zone. A detailed discussion of the environment of the coastal zone follows a summary of the other four zones.

\section{Sand Sheet}

This zone is a stabilized and active dune area that sustains a savanna habitat of grasslands and scattered oak mottes. The sand sheet includes all of Kenedy and Brooks counties and parts of Jim Hogg, Starr, Kleberg, Duval, and Jim Wells counties. The southern periphery of the sand sheet, consisting of the Norias sand lobe and Rudolph sand/loess plain, extends into northern Hidalgo and 


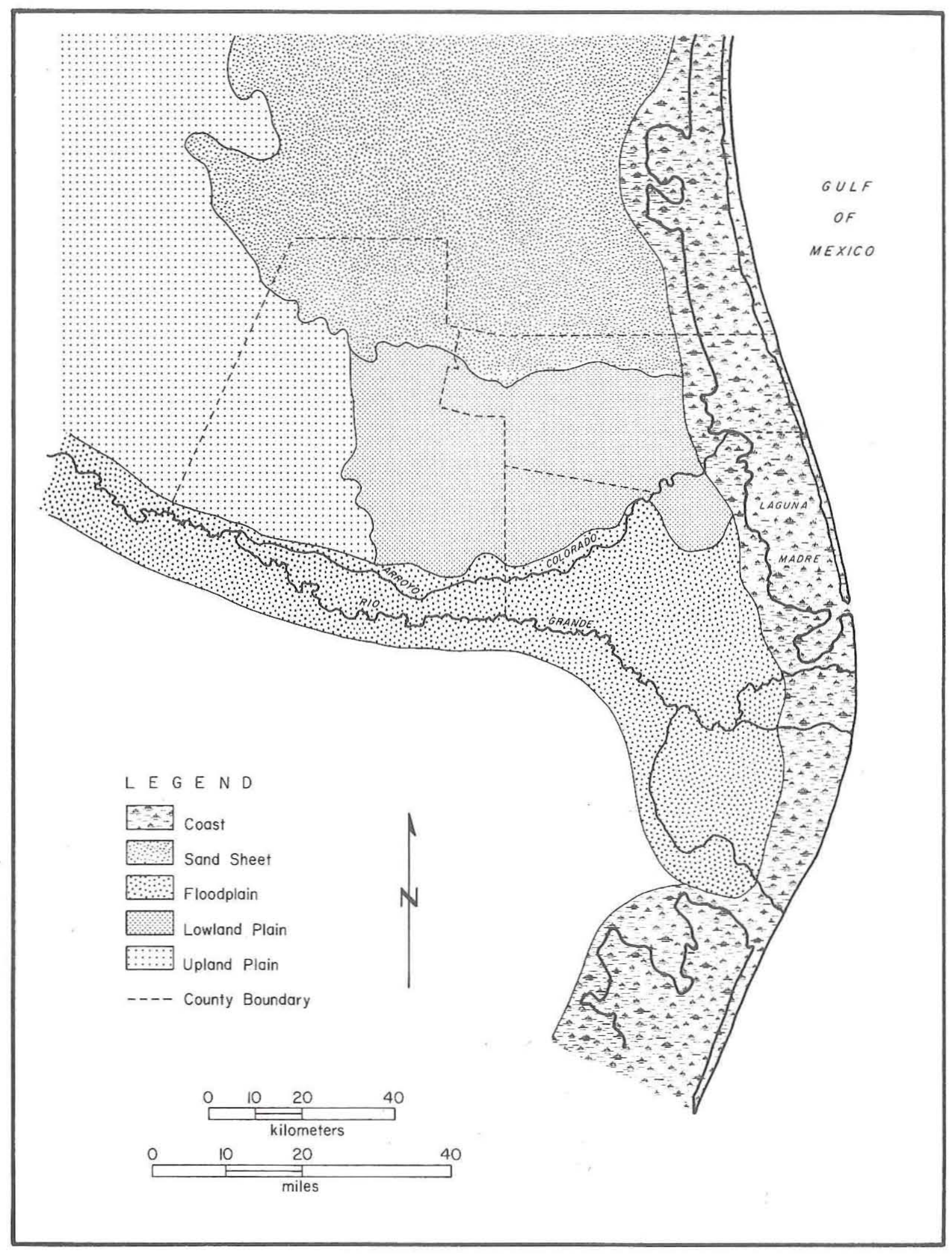

Figure 5. Map of environmental zones of the Lower Rio Grande Valley (from Bousman et al. 1990). 
Willacy counties.

The dune fields probably formed when climatic conditions became increasingly arid and surfaces were deflated by southeasterly prevailing winds (Brown et al. 1980). While only one chronometric date (11,450 B.P., Brown et al. 1980:21) is available from the dunes of the sand sheet, Bousman et al. (1990:136, 218) note several radiocarbon assays between 12,780 and 4300 B.P. from a deflated late Pleistocene soil upwind of the sand sheet. This suggests that the sand sheet accumulated during a more-xeric period in the early to middle Holocene.

Oak mottes within the sand sheet are most common on the higher sand hills and are replaced by prairie grasses or brush on lower ground surfaces and near the coast. The oak mottes consist predominantly of live oak, Quercus virginiana or $Q$. oleoides quaterna. Prairie communities consist of Andropogon sp., Panicum sp., Paspalum sp., Elyonurus sp., Brachiaria sp., Cenchrus sp., and Chloris sp. (Johnston 1955:95106). Mesquite and thorny brush thickets are present but not common. The oak mottes provide habitat for many animals, including deer, turkey, javelina, turtles, snakes, and rodents.

\section{Lowland Plain}

This zone consists of a featureless landscape with no natural drainages. Dispersed over the surface are shallow blowouts which form seasonal playas surrounded by thin eolian deposits on the Pleistocene Beaumont Formation, an abandoned delta of the Rio Grande. The lowland plain zone is analogous to the Raymondville Alluvial Plain noted by Mallouf et al. (1977:Figure 19). Within the southwestern portion of the zone, dunes of the Fayesville-Edinburg and Hargill conical dune fields commonly overlie the Beaumont Formation.

Land-clearing activities related to agriculture and ranching have decimated much of the natural vegetation in the lowland plain. Indigenous floral communities include prairies, brush thickets, and rare oak mottes. Greater plant diversity occurs around the playas and blowouts, where species with greater water requirements, including sugar hackberry (Celtis laevigata), sweet acacia (Acacia farnesiana), and Eragrostis spicata, a coarse bunch grass, thrive. These "wooded potholes and basins" provide important habitat for migratory birds and other terrestrial fauna as well (Jahrsdoerfer and Leslie 1988:8).

Prairie communities consist commonly of perennial grasses (Cenchrus, Eragrostis, Chloris, Aristida, and Sporobolus) and forbs (Desmanthus virgatus depressus, Cassia fasciculata, Croton spp., and Eriogonum multiflorum) (Johnston 1955: 107-109). Jahrsdoerfer and Leslie (1988:8) refer to the brush thickets as the mid-delta thorn forest. The mid-delta thorn forest community consists of xerophytic short trees and shrubs, including mesquite (Prosopis juliflora), spiny hackberry (Celtis pallida), Texas ebony (Pithecellobium flexicaule), anacua (Ehretia anacua), yucca, (Yucca treculeana), prickly pear (Opuntia spp.), and Texas lantana (Lantana horrida). These species often grow in dense, impenetrable thickets.

\section{Upland Plain}

The upland plain is characterized by low, rolling, calcareous, gravelly hills of the Goliad Formation and an increase in perennial and ephemeral streams. Elevations increase to over $120 \mathrm{~m}(400 \mathrm{ft})$ westward from a small escarpment bordering the lowland plain. Stabilized dunes of the Faysville-Edinburg dune field are present along the eastern and southern margins of the zone. One major distinction between the upland plain and lowland plain, at least presumably to the prehistoric inhabitants of the region, is the presence of knappable lithic materials in the upland plain.

The characteristic plant community is a low, dense chaparral which Johnston (1955:67-68) terms "short brush." Isolated riparian strips of dense brush occur along streams and arroyos. Defined as the ramadero biotic community, these riparian zones include such woody plant species as spiny hackberry $(C$. pallida), sweet acacia (A. farnesiana), retama (Parkinsonia aculeata), bluewood condalia (Condalia obovata), and mesquite $(P$. juliflora) (Jahrsdoerfer and Leslie 1988:8). The ramaderos provide habitat for many animals, including white-winged dove and deer.

\section{Rio Grande Floodplain and Delta}

This zone consists of the Rio Grande floodplain and its modern delta. The Rio Grande is a major source of perennial water in the region, and its significance cannot be overestimated. The 
topography of the zone is flat or gently sloping due to the very low stream gradient. Scattered throughout the zone are many oxbow lakes or resacas which hold freshwater. The delta is an active wetlands formed by many small and large distributary channels which constantly change course. Clay dunes are common along the Gulfward margin of the delta. Both environments provide habitat for numerous terrestrial and aquatic vertebrates (Jahrsdoerfer and Leslie 1988:8).

Much of the indigenous plant community has been removed due to agriculture and urban development. Biotic communities within the Rio Grande floodplain and delta include, from the upper valley to the delta, the Chihuahuan thorn forest, the upper valley flood forest, the midvalley riparian woodland, and the sabal palm forest (Jahrsdoerfer and Leslie 1988:7-8). Tree species common in all of the communities include black willow (Salix niger), cedar elm (Ulmus crassifolia), Berlandier ash (Fraxinus berlandieriana), western soapberry (Sapindus drummondii), sugar hackberry $(C$. laevigata), Texas ebony $(P$. flexicaule), and thickets of mesquite ( $P$. juliflora) and spiny hackberry $(C$. pallida). Limited to the sabal palm forest are Mexican palmettos (Sabal mexicana) or sabal palms. Beneath these forested canopies thrive several different types of shrubs and vines, including Barbados-cherry malpighia (Malpighia glabra), short-fruited serjania-vine (Serjania brachycarpa), and saw greenbrier (Smilax bona-nox).

\section{Coastal Zone}

This zone consists of a strip of land parallel to the coastline. A number of diverse environments are present, including the Gulf of Mexico, barrier islands, lagoons, wind-tidal flats, clay dunes, rare salt marshes, and sand dunes. The number of and interplay between both aquatic and terrestrial environments and freshwater and saline environments make parts of the coastal zone highly productive and complex but at the same time very fragile. Hurricanes and prolonged droughts, which affect the salinity, precipitation, and other climatic conditions of this zone, can have devastating consequences on the biological communities of the coast.

\section{Geology and Holocene Geomorphology}

The coastal zone is characterized by Holocene deposits of the Laguna Madre, Padre Island, lagoonal deltas, wind-tidal flats, and clay dunes overlying the Pleistocene Beaumont Formation. The Beaumont Formation in this part of the Lower Rio Grande Valley is a part of the Raymondville fluvial system, the most recent and most basinward occurrence of the Beaumont Formation. Although undated in south Texas, it probably was deposited prior to $60,000-50,000$ B.P. during a brief Wisconsin interglacial high sea stand (Brown et al. 1980:47). Deltaic deposits of the Raymondville system are assumed to lie buried under the Laguna Madre, Padre Island, and the inner shelf (Brown et al. 1980:47). The Raymondville fluvial system consists of intertwined meanderbelt sands and floodplain muds. To the north the sand sheet overlies the meanderbelts, and basinward the meanderbelts underlie the wind-tidal flats and clay dunes between Cayo Atascosa and Fourmile Slough. The southern margin of the Raymondville meanderbelt system was eroded by the late Pleistocene entrenchment of the Rio Grande during the Last Glacial Maximum (Brown et al. 1980:51). This portion of the mainland shore consists of Holocene deltaic deposits of the Rio Grande.

The end of the Pleistocene initiated many changes to the south Texas coast. Sea level began to rise, which included periods of initial rapid rise, stand stills, and a possible maximum high stand of $1.5 \mathrm{~m}$ above current sea level between 45003000 B.P. (Frazier 1974; Prewitt and Paine 1987). Compactional subsidence, lack of run-off from the mainland, and increasing aridity have resulted in the formation of extensive wind-tidal flats along the shoreline and hypersaline conditions in the Laguna Madre. Saltwater and freshwater marshes, which are present farther north along the Texas coast, are virtually absent along the south Texas coast due to arid climatic conditions, lack of drainage or run-off into the Laguna Madre, and prevailing southeasterly winds (Brown et al. 1980: 72). The wind-tidal flats of the mainland are predominantly mud with minor amounts of sand, algal-bound mud, and algal mats. The surfaces of these flats are usually covered with blue-green algae and desiccation cracks and polygons. 
Associated with the wind-tidal flats are numerous clay dunes, which form as a result of sand-sized aggregates of clay being transported from the surface of the wind-tidal flat to its leeward margin (Price 1963). Often clay dunes accrete on remnants of delta-plain distributary levees (Brown et al. 1980:73; Huffman and Price 1949:124). It is estimated that the clay dunes along the south Texas coast started to accrete around $4500-5000$ B.P. (Prewitt and Paine 1987; Price and Kornicker 1961). Many of the presumably older and more basinward clay dunes that formed on the Holocene delta of the Rio Grande in Cameron County are now inactive islands, as their wind-tidal flats have been drowned due to compactional subsidence of the delta and encroachment of the Laguna Madre.

The shoreline also experienced the headward erosion of streams, most notably the Arroyo Colorado which has been eroding headward throughout the Holocene. It has pirated run-off from a portion of the northern Holocene Rio Grande floodplain. The Arroyo Colorado debouches directly into the Laguna Madre and formerly built a large lagoonal delta upon which wind-tidal flats and clay dunes have formed (Brown et al. 1980:21). Flow and discharge through the Arroyo Colorado is limited, with peak discharge associated with floods from tropical storms. The Mercedes-Raymondville floodway was a similar headward-eroding floodway that discharged into the Laguna Madre near Fourmile Slough during the Holocene (Price 1958:53). The Mercedes-Raymondville floodway, which is now abandoned, also formed a lagoonal delta on which wind-tidal flats and clay dunes formed (Brown et al. 1980:63).

As sea level reached its approximate modern level, offshore bars and spits developing from a marine-transgressive Holocene Rio Grande delta merged with discontinuous offshore barriers to form Padre Island and the Laguna Madre between 3400 and 1900 B.P. (Brown et al. 1980:22). Broad wind-tidal flats developed along the eastern margin of the Laguna Madre, where washover fan and eolian sediments from Padre Island filled the lagoon. South Padre Island formed from the longshore transport of sediment delivered to the Gulf by the Rio Grande. However, for the last few thousand years the sediment load and discharge of the Rio Grande have decreased, leaving the barrier islands starved for sediment (Brown et al. 1980:
20). This has left the south Texas coast in a state of marine transgression. The mainland shore subsides and retreats, marked by wind-tidal flats, while South Padre Island moves landward and the Laguna Madre fills. At the same time, the Laguna Madre has moved westward to a lesser extent over the subsiding Pleistocene and Holocene coastal plain. As a result, the Laguna Madre has become narrower and parts of the lagoon have become shallower, while South Padre Island has become thinner and increasingly erosional (Brown et al. 1980:22). More importantly, this process has accelerated due to even more decreases in the sediment load of the Rio Grande as a result of dam construction and agricultural irrigation upstream (Brown et al. 1980:32).

\section{Soils}

The soils of the coastal zone consist of various nonsaline and saline, sandy and clayey Aridisols and Entisols. The soils belong to three different soil associations that include the GalvestonMustang-Dune land, the Barrada-Lalinda-Arrada, and the Satatton-Tatton (Turner 1982).

Soils of the Galveston-Mustang-Dune land association are nearly level to rolling, nonsaline, sandy soils formed on the beach, fore dunes, and mid-barrier flat of barrier islands and coastal mainland sand dunes. Galveston series soils are predominant in this association (Turner 1982:10). Galveston soils are classified as Typic Udipsamments, which are sandy Entisols of humid climates (Buol et al. 1980:230).

Barrada-Lalinda-Arrada soils consist of nearly level to gently sloping, saline and nonsaline, clayey and loamy soils formed on mainland windtidal flats (Barrada and Arrada soils) and clay dunes (Lalinda soils). Barrada and Lalinda soils make up the majority of the Barrada-LalindaArrada association (Turner 1982:13). Barrada soils are Aquollic Salorthids, Aridisols with shallow salic horizons and thin, wet mollic epipedons. Arrada soils are classified as Typic Salorthids, Aridisols with shallow salic horizons. Lalinda soils are classified as Ustollic Camborthids, which are Aridisols with cambic horizons and dry, thin mollic epipedons and/or gypsic or calcic horizons below the cambic horizon. Buried soils are common (Buol et al. 1980:253, 264).

The third soil association, Satatton-Tatton, 
includes nearly level, saline, sandy soils formed on the backside of barrier islands and wind-tidal flats. Satatton and Tatton soils are the predominant soils (Turner 1982:12). Satatton soils are Typic Salorthids, which are Aridisols with shallow salic horizons. Tatton soils are Typic Psammaquents, wet, sandy to loamy sand Entisols (Buol et al. $1980: 230,253)$.

\section{Fauna and Flora}

Three distinctive plant communities occur within the coastal zone, with their distributions controlled by their varying tolerances to windborne salt and saline soils and, to a lesser extent, by surface elevations (Johnston 1955). The most inland community is dominated by Gulf cordgrass or sacahuista (Spartina spartinae) with rare occurrences of Houstonia nigricans and Hybanthus verticillatus platyphyllus (Johnston 1955:112-116).

Among the more saline soils of the wind-tidal flats and clay dunes and closer to the saltwater is the Borrichia-Batis-Monanthochloe community (Johnston 1955:117-118). The dominants of this herbaceous community are bushy sea-oxeye (Borrichia frutescens), salt-flat grass (Monanthochloe littoralis), and maritime saltwort (Batis maritima). This community commonly occurs on low-lying coastal clay soils and frequently flooded, algal-mat-covered wind-tidal flats surrounding clay dunes. Many of the clay dunes support dense thorny brush, such as mesquite $(P$. juliflora), prickly pear (Opuntia spp.), trecul yucca ( $Y$. treculeana), common lantanta ( $L$. horrida), Texas ebony ( $P$. flexicaule), and Berlandier fiddlewood (Citharexylum berlandieri). Grasses, like the bunch grass Sporobolus wrightii, are also common on the dunes (Brown et al. 1980:108).

Nearest the strand in the most saline conditions is the Batis-Salicornia-Suaeda community, a community of succulent halophytes (Johnston 1955: 118-120). The dominant plants include $B$. maritima, Salicornia perennis, Salicornia bigelovii, Cakile lanceolata geniculata, Suaeda conferta, and Suaeda linearis.

A number of salt-tolerant grasses grow on the mid-barrier flats and fore dunes of barrier islands, including seacoast bluestem (Schizachyrium scoparium var. littoralis), switchgrass (Panicum virgatum), seaoats (Uniola paniculata), marshhay cordgrass (Spartina patens), and gulfdune paspalum (Paspalum monostachyum). The beaches and backbeaches of the barrier islands are largely barren.

Plants from the coastal zone provide little in the way of food resources; rather, shellfish, fish, and waterfowl provide the greatest economic opportunities, involving lesser risks and greater returns. Larger game such as deer, javelina, rabbit, and turkey are available along the coast but involve greater risks to obtain.

Species diversity and distribution depend largely on salinity levels throughout the different environments. The hypersaline conditions of the Laguna Madre preclude many species from occupying this environment. Generally, species diversity decreases away from the tidally influenced inlets and bays of the Laguna Madre, such as Brazos Santiago Pass. Shellfish that can tolerate the hypersaline conditions include Laevicardium mortoni, Tellina tampaensis, and Anomalocardia auberiana (Andrews 1981; Brown et al. 1980:108). Fish, including black drum (Pogonias cromis), speckled sea trout (Cynoscion nebulosus), and redfish (Sciaenops ocellatus) also are able to tolerate the waters of the Laguna Madre. Inlets and bays of lower salinities, due to tidal influences from the open Gulf or freshwater run-off from the mainland, are inhabited by many more shellfish species including Crassostrea spp., Ostrea spp., Crassinella spp., and Tellidora spp. (Andrews 1981; Brown et al. 1980:108). Species diversity and number are also higher in the surf zone of the barrier islands. Shellfish include Arca spp., Anadara spp., Busycon spp., Donax spp., and a diverse number of crustaceans and fish (Brown et al. 1980:108).

The coastal zone is inhabited by abundant waterfowl which increase in availability seasonally due to the many migratory birds, especially ducks and geese, that winter on the south Texas coast. The distribution and number of waterfowl are less restricted by differences in salinities, and they certainly were an important food source prehistorically in all environments of the coastal zone. 



\section{PREHISTORIC BACKGROUND}

This chapter presents an overview of the prehistory and cultural chronology of the Lower Rio Grande Valley and a summary of previous archeological investigations associated with the Hidalgo-Willacy drainage ditch project.

\section{CULTURAL CHRONOLOGY}

An understanding of the prehistory of the Lower Rio Grande Valley remains elusive. Detailed and extensive archeological investigations prior to 1980 are lacking (Hester 1981:119-128), complexes and tool assemblages are not well defined, and even projectile point chronology (dominated by simple triangular styles) has not been clearly established (although, see Jelks 1978). The lack of an established absolute chronology for the region further hinders an understanding of the region's prehistory, as do the well-documented land modifications and disturbances related to historic agricultural and ranching activities (Bousman et al. 1990:17-18; Day et al. 1981:1012; Mallouf et al. 1977:23-26). Attempts to interpret the cultural chronology of the Lower Rio Grande Valley rely heavily on comparsions of artifact and site types with those from surrounding areas such as the Lower Pecos, Central Gulf Coast, Central Texas, and Northeastern Mexico (e.g., Black 1989; Mallouf et al. 1977).

The prehistoric cultural sequence of the Lower Rio Grande Valley can be divided into three broad periods: Paleoindian, Archaic, and Late Prehistoric. The Paleoindian period $(11,500-$ 7000 B.P.) represents the earliest known cultural manifestation in North America but is poorly known and/or represented in the Lower Rio Grande Valley. The period is often described as having been characterized by small but highly mobile bands of foragers who were specialized hunters of Pleistocene megafauna. However, a more accurate view of Paleoindian lifeways probably includes the utilization of a much wider array of resources. The late Pleistocene and early Holocene environment of the Lower Rio Grande Valley was markedly different than today, offering different resources and subsistence challenges. Paleoenvironmental data from stable isotope studies suggest that temperatures may have been $10^{\circ} \mathrm{F}$ to $15.4^{\circ} \mathrm{F}$ cooler than today at the end of the Pleistocene (Bousman et al. 1990:97-98). Climatic conditions were also probably arid to semiarid. Bousman et al. $(1990: 94,98)$ have suggested that plant communities were dominated by $\mathrm{C}_{4}$ and/or CAM plants, such as prickly pear and agave. Isolated Paleoindian projectile points collected from surface contexts indicate that the area was occupied by Paleoindian groups; however, intact cultural deposits representing Paleoindian occupations are unknown. A Folsom base was collected from a site (41CF54) on Cayo Atascosa, just south of the Laguna Atascosa (Anderson field notes, TARL files). Other projectile points have been collected from eolian dune fields in Willacy County and the La Perdida Site in Starr County (Mallouf et al. 1977:167-168; Weir 1956).

The Archaic period (7000-800 B.P.) is also poorly represented and understood. The Archaic represents a shift to the hunting and gathering of a wider array of animal and plant resources and a decrease in group mobility (Willey and Phillips 1958:107-108). Early to middle Archaic sites are extremely rare in the Lower Rio Grande Valley; this most likely is due to the onset of more-xeric conditions and eolian deflation of occupational 
surfaces during the early and middle Holocene (see Bousman et al. 1990; Hall et al. 1987). Evidence of utilization of the Lower Rio Grande Valley by Archaic peoples again comes from surfacecollected artifacts, "primarily by unstemmed triangular thin bifaces, gouges, and infrequent stemmed dart points" (Hall et al. 1987:17-18). Late Archaic sites are not as infrequent, but often their components are mixed with later Late Prehistoric assemblages, e.g., 41HG118 (see Hall et al. 1987). Human remains recovered from the Lower Rio Grande Valley have yielded late Archaic radiocarbon assays (Bousman et al. 1990: 99-100), providing the earliest conclusive evidence of human occupation of the area. It is probably no coincidence that the apparent increase in sites during the late Archaic is coeval with the beginning of landscape stability and soil development (Hall et al. 1987:57-59). More-mesic conditions are apparent throughout much of Texas around 2500 B.P. and are represented by a predominance of $\mathrm{C}_{3}$ plants in the region (Bousman et al. 1990:9495).

MacNeish (1947) defined two Archaic complexes, Abasolo and Repelo, for northeastern Tamaulipas and the Lower Rio Grande Valley based mainly on surface-collected artifacts. Based on stratigraphic superpositioning, MacNeish (1958: Table 30) estimated that the Repelo Complex dates from 5000-4000 B.P. and the Abasolo Complex from roughly 4000-2000 B.P. However, few sites bearing Repelo and Abasolo components have been excavated, and radiocarbon assays are not available.

The Late Prehistoric ( $800-300$ B.P.) is the best known of the three periods. It is defined by the presence of the bow and arrow and marked by the production of small triangular arrow points beginning around 800 B.P. (Hester 1981:122). The emergence of ceramics and horticulture, which is apparent during the Late Prehistoric period in other parts of Texas, is absent or very nebulous in the region. Increasingly xeric, but modern, conditions emerged at this time. Stable carbon isotope analysis suggests that plant communities were in a state of flux and were marked by a steady increase in $\mathrm{C}_{4}$ grasses (Bousman et al. 1990:94-98).

Sayles (1935) was the first to define a cultural complex - the Brownsville Phase - for the Lower Rio Grande Valley. MacNeish (1947, 1958: 186-192) later defined a Brownsville Complex, based on the collections and work of Anderson (1932), Sayles (1935), and Mason (1935). MacNeish (1958) also defined a Barril Complex beginning around A.D. 1000 and slightly predating the Brownsville Complex. The Brownsville and Barril complexes are characterized by a welldefined shell industry and were determined to be Late Prehistoric based on the presence of small triangular arrow points and Huastecan-like ceramics indicative of the Panuco Periods V and VI (MacNeish 1958:189). Prewitt (1974:62) suggested that the Brownsville Complex was also contemporaneous with the Rockport Phase to the north on the central Gulf Coast of Texas. The Barril Complex is distinguished by the presence of rare conical bone projectile points and abundant shell columella projectile points, while the Brownsville Complex is uniquely associated with conical pumice pipes. Barril Complex sites are largely limited to the south side of the Rio Grande in northeastern Tamaulipas, while Brownsville Complex sites are situated north of the river. MacNeish's assemblages, cultural complexes, and their geographical distributions, however, are based only on surface sites and surface-collected artifacts. A few excavated burials and cemetery sites have been attributed to the Brownsville Complex, even though radiocarbon assays are not available (Collins et al. 1969; Hester and Rodgers 1971; Hester and Ruecking 1969). The Ayala Site is attributed to the Late Prehistoric Brownsville Complex due to its stratigraphic position over an earlier Repelo-Abasolo midden (Hester and Ruecking 1969:147).

Historic aboriginal sites are noted by the presence of materials of European origin, including metal and glass projectile points, trade beads, and wheelmade or glazed ceramics. Four historic aboriginal sites (41CF8 and three other sites discovered by A. E. Anderson) in Cameron County have yielded glass arrow points and wheelmade or glazed sherds (Anderson 1932; Prewitt 1974). The latest record of aboriginal inhabitants in the area was in A.D. 1886 near Reynosa, Mexico (Salinas 1986:258).

\section{PREVIOUS INVESTIGATIONS}

The earliest archeological investigations in the region can be attributed to A. E. Anderson, a civil engineer from Brownsville, Texas. Between 
1908 and 1940, he made extensive systematic surface collections from sites north and south of the river in the Rio Grande delta (Anderson 1932). Later, Sayles (1935), Campbell (1947), Kelley (1947), and MacNeish (1947, 1958) defined cultural complexes for the Lower Rio Grande Valley and surrounding regions based on their own work and Anderson's collections. Ensuing archeological investigations were few and simplistic. Most involved further archeological surveys and revisitation of earlier recorded sites (e.g., Hall and Grombacher 1974; Prewitt 1974) and salvage excavation of human burials (Collins et al. 1969; Hester and Rodgers 1971; Hester and Ruecking 1969; Mallouf and Zavaleta 1979). By far the most intensive and comprehensive archeological investigations have occurred since 1976 and are associated with the Hidalgo-Willacy Drainage Ditch project. These investigations have documented 161 archeological sites, ${ }^{1}$ of which 11 have undergone testing or excavation. Geomorphological and paleoenvironmental studies also have been carried out in association with many of the archeological investigations. These investigations have consistently revealed the unique nature of the archeological record in the Lower Rio Grande Valley-a record characterized by disturbed contexts, widely variable site densities, short-term occupations, and low artifact densities.

The first cultural resources investigation related to the Hidalgo-Willacy Drainage Ditch was an archeological survey conducted by the Office of the State Archeologist for the U.S. Army Corps of Engineers, Galveston District (see Mallouf et al. 1977). Since then, all additional archeological investigations have been conducted by Prewitt and Associates, Inc. for the U.S. Army Corps of Engineers and local sponsors Hidalgo County Drainage District No. 1 and Willacy County Drainage District No. 1. This report represents the final archeological investigations associated with the Hidalgo-Willacy Drainage Ditch project.

The initial survey in 1976 sampled 12 areas, each measuring $2 \times 2 \mathrm{~km}$, and documented 49 sites (Mallouf et al. 1977). The goal of this survey was to provide a predictive assessment of cultural

\footnotetext{
${ }^{1}$ This does not include isolated finds or isolated finds that were given site trinomial numbers during earlier projects.
}

resources expected to be impacted by the construction of the drainage ditch. The project universe was divided into seven environmental zones on the basis of topography, geology, hydrology, and to a lesser extent floral communities. The 12 survey areas sampled the environmental zones that were expected to be traversed (six of seven zones) by the drainage ditch. Examination of the survey results led Mallouf et al. (1977:244-254) to suggest that the intensity of future surveys should vary from zone to zone due to differences in predicted site density and the extent of humaninduced land-surface modification. Mallouf et al. (1977) also provided a review of the Lower Rio Grande's prehistory, ethnohistory, and previous archeological investigations.

In 1980 the U.S. Army Corps of Engineers, along with local sponsors Hidalgo County Drainage District No. 1 and Willacy County Drainage District No. 1, funded archeological surveys of the drainage ditch rights-of-way in Hidalgo and Willacy counties. The investigations included a sample survey of different ditch segments, including the Main Floodwater Channel, the North Main Drain, the South Main Drain, the Edinburg Stub, the East Lateral, the Southwest Lateral, and pumping stations along the North Floodway and the Arroyo Colorado (see Day et al. 1981:2-4). Many of these ditch segments had already been excavated at the time of the investigations, so the survey focused on the exposed banks of the ditches. The local sponsors funded the survey of the proposed North Ditch, which runs parallel to and south of the South Main Drain. In all, the 1980 survey documented 54 new archeological sites, two of which (41WY50 and 41WY60) were selected for limited testing. In addition, 10 previously recorded sites were documented. Day et al. (1981) recommended that 15 of these sites, including 41WY50 and $41 \mathrm{WY} 60$, warranted further investigations and that testing be conducted to determine their eligibility for listing on the National Register of Historic Places.

The investigations by Day et al. (1981) followed the recommendations of Mallouf et al. (1977) by varying the survey intensity of certain channel segments depending on the environmental zone in which the segment was located. Day et al. (1981) also produced the first radiocarbon assay from the Lower Rio Grande Valley. This uncorrected assay of $540 \pm 110$ B.P. was on the bone 
apatite fraction of a human burial recovered from site 41 WY50. A second radiocarbon assay was later obtained from the collagen fraction, revealing a much earlier $\delta^{13} \mathrm{C}$-corrected age of $1415 \pm$ 140 B.P. (Bousman et al. 1990:99).

Two of the 15 sites recommended for National Register testing, prehistoric sites 41 WY71 and 41WY72, were tested in the summer of 1981 (see Day 1981). These investigations were sponsored by the Hidalgo County Drainage District No. 1 and the Willacy County Drainage District No. 1 because they were recorded during the survey of the proposed North Ditch, which also was funded by the local sponsors. Site 41 WY71 did not yield information warranting its nomination to the National Register. However, site 41 WY72 was considered eligible for listing on the National Register, which resulted in a southward shift of the ditch alignment to avoid any significant impacts to the site. Site 41 WY72 was interpreted as a stratified, semipermanent campsite containing a relatively high density of cultural materials (Day 1981:34). Artifact distributions suggested that discrete activity areas were present. Within the artifact assemblage were obsidian debitage and ceramic sherds, indicating that the site is Late Prehistoric in age (Day 1981:34). Obsidian source data, which was not available at the time of publication (i.e., Day 1981), is presented here for the first time. Two obsidian flakes recovered from 41 WY72 were submitted to Dr. Thomas R. Hester for trace element analysis as part of the Texas Obsidian Project (TOP). Based on the $x$-ray fluorescence trace element analysis performed by the Lawrence Berkeley Laboratory, Berkeley, California, the likely source of the two flakes is Cerro de las Navajas (Pachuca), in the State of Hidalgo, Mexico (TOP specimen 166, BA $<15 \mathrm{ppm}, \mathrm{Ce}=119 \pm 12 \mathrm{ppm}$; TOP specimen 167 , BA <26 ppm, Ce = $120 \pm 13$ ppm [Hester 1993]).

In 1982, archeological investigations sponsored by the Willacy County Drainage District No. 1 were conducted along the Main Floodwater Channel, consisting of proposed and existing ditch segments (see Mercado-Allinger 1983). The investigations included a survey during which 10 sites were recorded. Five of these sites (41WY84, 41WY86, 41WY89, 41WY90, and 41WY91) were assessed as being potentially eligible for listing on the National Register of Historic Places. Testing was recommended for these sites prior to construc- tion of the proposed channel segments. All five sites were similar in terms of integrity, topographic location, and cultural materials present. Due to these similarities, one site (41WY84) was selected for initial testing to better assess the integrity and nature of these resources. The testing of 41 WY 84 revealed that the site consists of thinly dispersed cultural materials in a highly disturbed context and did not warrant further investigations; therefore, testing of the remaining sites was canceled.

In November 1985, excavated segments of the ditch in Hidalgo and Willacy counties were surveyed and 13 sites were documented (see Hall et al. 1987). Many of these sites had not been visible before ditch construction, and many could be discovered only after prolonged exposure of the excavated ditch slopes to the elements. Thus, postconstruction survey actually increased the discovery rate of the region's cultural resources.

Archeological investigations recommenced in the spring and summer of 1986 and included survey and testing and assessments of previously recorded sites (Hall et al. 1987). Geomorphological and paleontological studies also were conducted. Surveys were conducted along existing and proposed ditch segments in Hidalgo and Willacy counties. In all, 43 sites, including the 13 sites recorded in November 1985, were documented. One of these, the Sardinas Resaca Site (41HG118), was intensively investigated through the excavation of backhoe trenches and test pits and a controlled surface collection. Artifacts recovered from the site suggest that it was occupied during the late Archaic and possibly the Late Prehistoric periods. Deposits containing cultural materials were found to be severely disturbed due to recent landscape modifications. Geomorphological studies and radiocarbon assays from soil humates provided useful insights into the age and development of the landforms associated with the site.

Paleontological studies focused on the recovery of seven Pleistocene tortoise (Gopherus hexagonatus) specimens. Although the specimens apparently were not associated with human activity, they did provide important paleoenvironmental information (Westgate 1987).

Hall et al. (1987:76) also reviewed the status of all of the sites and isolated finds documented through the various cultural resources investigations associated with the Hidalgo-Willacy Drainage Ditch. At the time, recommendations for 
32 sites were considered complete, either through testing, monitoring, or avoidance. Two sites, 41WY72 (Day 1981) and the Sardinas Resaca Site (Hall et al. 1987) had undergone testing and were declared eligible for listing on the National Register of Historic Places. Two other sites, 41WY71 (Day 1981) and 41WY84 (MercadoAliinger 1983) had been tested and were determined to be ineligible for listing on the National Register, along with four other sites (41WY86, $41 \mathrm{WY} 89,41 \mathrm{WY} 90$, and $41 \mathrm{WY} 91$ ) on the basis of similarities to $41 \mathrm{WY} 84$. Recommendations for the other 24 sites were considered complete because the sites were either avoided or monitored, revealing that further work was not necessary.

Recommendations for 56 sites, at that time yet to be completed, included National Register testing of 26 sites and monitoring of 30 sites. Eighteen of the 26 sites recommended for testing were recorded during work sponsored by the Hidalgo County Drainage District No. 1 and the Willacy County Drainage District No. 1. Hall et al. (1987:77) suggested that a sample of seven sites initially be tested and that the research strategies include four specific approaches: (1) geomorphological and stratigraphic studies of sites as they are exposed in the ditch walls; (2) obtaining chronometric dates from culturally relevant strata through radiocarbon assays of soil humates or other organic materials; (3) hand excavation of an average of $4 \mathrm{~m}^{2}$ for each site and utilizing features exposed in ditch walls to the maximum advantage; and (4) opportunistic collection of additional cultural materials that might be exposed in the ditch walls.

Prior to archeological testing, additional survey and site monitorings were conducted in 1988 (see Quigg et al. 1989). Five additional prehistoric sites (41HG135 through 41HG139) were recorded along proposed realignments of the Southwest and Mercedes laterals and the Rado and West Main drains in Hidalgo County. It was recommended that all five sites be monitored after construction (Quigg et al. 1989). In addition, four previously recorded sites, including the Sardinas Resaca Site, were revisited and their current status evaluated.

The archeological testing proposed by Hall et al. (1987) was undertaken in the summer of 1989 (see Bousman et al. 1990). Five sites (41HG128, 41WY112, 41WY113, 41WY134, and 41WY140) were recommended for Phase II testing in a 1988 work plan submitted to the Hidalgo County Drainage District No. 1 and the Willacy County Drainage District No. 1.

An earlier technical proposal by Prewitt and Associates, Inc. identified four major goals for archeological investigations in the Lower Rio Grande Valley and provided a theoretical model of hunter-gatherer mobility and territorial organization. The four major goals were to develop the ethnohistorical, archeological, and paleoenvironmental records, and then, from this data base, develop a synthesis of prehistoric occupations. Past ethnohistorical research (Campbell 1988; Ruecking 1953, 1955; Salinas 1986) provides a detailed ethnohistorical record, and no further primary research was necessary. It was recommended, however, that additional archeological and paleoenvironmental data were needed.

With these goals in mind, National Register testing was carried out at the five prehistoric sites. These investigations included stable isotope analyses and radiocarbon dating to study paleoenvironments and prehistoric human diets, as well as reanalysis of artifacts from other sites. The synthesis of this information resulted in the development of testable models of hunter-gatherer land use, incorporating optimal foraging theory and assuming that territorial divisions limited access to resources.

The nine environmental zones presented in Day et al. (1981) were condensed into five zones of resource exploitation by Bousman et al. (1990: 10-17). Three models were proposed. Model I proposes an unlimited-access exploitation pattern, where the region was occupied by a single group with a low population density. Model II proposes multiple groups and group territories focused on the exploitation of resources on the Rio Grande floodplain and less-intensive use of areas north of the floodplain. Model III proposes multiple group territories focused on the coast and less-intensive use of inland areas. These models grew out of initial formulations by Hester $(1976,1981)$, which were modified in the 1986 technical proposal.

The limited stable isotope analyses and radiocarbon dating done by Bousman et al. (1990) suggested a general warming trend for the Lower Rio Grande Valley since the late Pleistocene. Other stable isotope and radiocarbon studies revealed a dominance of $\mathrm{C}_{4}$ and/or CAM plants in 
the late Pleistocene and a fluctuating but steady increase in $\mathrm{C}_{4}$ grasses in the late Holocene (Bousman et al. 1990:94-98). The collagen fraction from the human remains recovered at 41 WY50 produced a $\delta^{13} \mathrm{C}$-corrected assay of 1415 \pm 140 B.P. The collagen fraction from human bone at $41 \mathrm{WY} 113$ produced a $\delta^{13} \mathrm{C}$-corrected age of $1088 \pm 90$ B.P. (Bousman et al. 1990:99). The stable isotope data from the human remains suggested that distinct coastal and inland dietary patterns may have existed. The remains of a specimen of late Pleistocene tortoise (Gopherus hexagonatus) collected during previous work were also radiocarbon dated. A $\delta{ }^{13} \mathrm{C}$-corrected radiocarbon age of $9360 \pm 415$ B.P. on apatite was produced.

Bousman et al. (1990:37) viewed the procurement of subsistence resources and lithic raw materials as subject to the same kinds of constraints. Lithic assemblages were considered integral elements of subsistence-related activities.
Given that the paramenters of the three models affected both subsistence activities and resource procurement patterns, it was assumed that an analysis of lithic assemblages could serve as a test of best fit between the models and the archeological data. An analysis of the frequencies and distributions of 12 lithic artifact types (e.g., resharpening flakes, cores, exhausted tools, earlyreduction debitage, and manufacture failures) from the five tested sites and other documented and tested sites in the region was performed. The collected data were inconclusive, although they slightly favored Model I, the unlimited-access exploitation pattern, over Model II or Model III.

While these investigations found that none of the five sites were eligible for listing on the National Register, many important aspects of the Lower Rio Grande Valley's geomorphology and past environments were brought to light. Valuable chronometric data, which in past investigations had been elusive, also were gained. 


\section{OBJECTIVES AND METHODS OF INVESTIGATIONS}

A technical proposal by Prewitt and Associates, Inc. submitted to the Hidalgo County Drainage District No. 1 and the Willacy County Drainage District No. 1 in 1986 outlined four major goals for future archeological investigations. The four goals were to develop the ethnohistorical, archeological, and paleoenvironmental records, and then, using this data base, to develop a synthesis of prehistoric hunter-gatherer mobility and territorial organization in the Lower Rio Grande Valley. Salinas (1986), Campbell (1988), and Ruecking (1953, 1955) provide adequate ethnohistoric records for the area. Initial attempts at providing a model of hunter-gatherer land use have been hampered by minimal archeological and paleoenvironmental data (Bousman et al. 1990; Hester 1981). However, "analysis and synthesis rarely occur in a single step, and the development of a research design, models, hypotheses, and tests of hypotheses should account for new data as it is recovered and should be fine-tuned as research proceeds" (Bousman et al. 1990:45). The objective of the current investigations is to provide additional archeological and paleoenvironmental data to advance the ongoing development of the fourth goal.

The following sections describe the methods and analyses utilized to obtain data from the archeological and paleoenvironmental record during the current investigations. The methods of the faunal and pollen/phytolith analyses are discussed in Appendixes C and D. The methods of the soil micromorphological studies are discussed in Appendix E.

\section{ARCHEOLOGICAL INVESTIGATIONS}

\section{Field and Documentation Methods}

The archeological field investigations at 41 WY50 and 41 WY 60 included mapping of the sites and excavation of $1-\mathrm{x}-1-\mathrm{m}$ test units and backhoe trenches. The sites were first re-located through the use of topographic maps and site descriptions by Day et al. (1981). Once the sites were located, initial surveys of the site areas were carried out, examining erosional faces for cultural materials and looking for prime test unit locations. Baselines were laid out using a transit and $60-\mathrm{m}$ tape along the crests of the dunes. Initial test units were laid out along the baselines at various intervals at the discretion of the Project Archeologist. Ensuing test units were placed either on the grid or off the grid over selected features that were exposed in the walls of backhoe trenches. Test units were excavated in 10-cm arbitrary levels. The excavation levels were numbered sequentially (in reverse geologic order) starting with Level 1 at the the ground surface. Vertical control was maintained by a line-level datum located at the surface of either the southeast corner of the test unit or the corner with the highest surface elevation. Elevations were obtained through transit readings. Excavated matrix from each level was water screened, with $75 \%$ being passed through 1/4-inch-mesh hardware cloth; the remaining portion (the northwest quadrant of each level) was passed through 1/16-inch-window screen. Materials recovered from the 1/4-inch and 1/16-inch 
screens were bagged separately and labeled with appropriate provenience data.

Backhoe trenches were utilized to detect buried features and cultural materials, as well as to provide geomorphological data. The backhoe trenches were placed on-site at the discretion of the Project Archeologist. A few backhoe trenches were placed off-site for additional geomorphological data. Backhoe trench excavations were monitored by the Project Archeologist or a member of the field crew. Upon completion of the excavations, the trench walls were cleaned and selected walls were profiled. These profiles depict the depth, thickness, and dip of each natural zone.

A contour map of each site was produced from transit readings. The test units, backhoe trenches, line level datums, baseline datums, and general topography were mapped with the transit and metric stadia rod. Mean sea level (MSL) was used as a vertical datum. Normally, the National Geodetic Vertical Datum of 1929 (NGVD) would be used as a vertical datum because it is more accurate than MSL; however, compactional subsidence along the Texas coast has rendered the NGVD unreliable. For mapping purposes, the water levels at the sites were read with the transit, and the time of day was recorded with these transit readings. Mean hourly tidal or water level records (relative to MSL and NGVD) for Port Mansfield, Texas, were provided by the National Oceanic and Atmospheric Administration (NOAA) (1993). The NOAA records reveal that the tidal range in the area is normally less than $9 \mathrm{~cm}$, and therefore for mapping purposes, the water level readings were given the value of " 0.0 " $\mathrm{m}$ and used as a vertical control.

Documentation of the field investigations includes photographic and written records. These include 35-mm color slides and black-and-white prints, photograph logs, test unit excavation forms recorded by excavation level, feature drawings and forms, field inventories of materials recovered, backhoe trench profile sketches and detailed stratigraphic and sedimentary descriptions, transit and mapping notes, sketch maps, and a daily journal kept by the Project Archeologist.

\section{Feature Designation, Documentation, and Excavation}

Several cultural features were encountered and defined at sites 41WY50 and 41WY60. Many of these were detected and documented by their cross-section exposures in the walls of backhoe trenches. Detection and designation of features proved to be a complex task for several reasons. All but two of the features are very shallow, small, basin-shaped hearths. Feature fills consist mainly of small dispersed pieces of charcoal, ashy sediments, and some oxidized sediments. The problematic task of identifying and defining such thin, ephemeral features was compounded by the fact that many of them occurred within dark organic A soil horizons or zones throughout the clay dunes. Some of these zones are thin and discontinuous, which made them at times look very much like discrete hearth features.

A set of conservative criteria was therefore utilized for defining hearth features to separate them from natural anomalies that resemble features. Feature designation considered morphology, content, and composition. Features had to be basin shaped, regardless of their thickness, in cross section and have distinct boundaries or limits. Features, regardless of size, had to contain charcoal and ashy sediments. Oxidized sediments along the bottom of the feature also were among the criteria for feature designation. Of course, some of these criteria disclosed a stronger presence than others, varying from feature to feature. Thus, if one criterion was distinctly or profoundly present while the presence of the other two was weak or ephemeral, feature designation was assigned.

Since almost all of the features were exposed and detected in the profiles of backhoe trench walls, feature documentation included detailed profiling and photographing the feature cross section. Small blocks of feature fill and surrounding matrix were cut from the profiles of two features at 41WY50 for micromorphological analysis (see Appendix E).

Selected features were excavated by placing test units adjacent to the backhoe trenches where the features were exposed. Features excavated in test units were drawn and photographed in plan view. All feature fill was collected, bagged, and labeled with appropriate provenience information for later analyses, including radiocarbon dating and pollen/phytolith studies. Elevations of the tops and bottoms of features were noted by the line-level datum located at the corner of the test unit and were recorded on feature forms. 
Charcoal samples were submitted to Beta Analytic, Inc. for radiocarbon dating. The charcoal was obtained from feature-fill matrix by floating the fill and later hand picking the charcoal from the light and heavy fractions. Unfortunately, the box containing these samples was lost by United Parcel Service.

\section{GEOMORPHOLOGICAL AND PALEOENVIRONMENTAL INVESTIGATIONS}

Geomorphological and paleoenvironmental characteristics provide a setting for and interact with cultural systems (Butzer 1982:6), making their study an integral and necessary part of any archeological investigation. Geomorphological and paleoenvironmental processes also represent important factors of site formation. The geomorphological investigations included the documentation of backhoe trench profiles, sediment grain-size analysis, and dating of sediment/soil humate samples by radiocarbon assay. Selected backhoe trench profiles were recorded in detailed (see Appendix A). Each profile description is based on the examination of a 50-100-cm-wide column within the trench wall. The neutral term "zone" is used to allow both stratigraphic and pedogenic variation in the profile to be described under the same nomenclature. Each zone is numbered sequentially from the top (surface) down. Munsell color (moist), consistency (moist), texture, structure, type and abundancy of inclusions, and lower boundary characteristics are described for each zone according to the guidelines and criteria presented by Buol et al. (1980) and Birkeland (1984). Final soil horizon classifications were made based on the guidelines of Birkeland (1984) and Bettis (1984). Selected sediment/soil samples were submitted to Beta Analytic, Inc. for chronometric dating by radiocarbon assay and to the Soils and Physical Geography Laboratory at the University of Wisconsin-Milwaukee for sediment grainsize and soluble salts analyses (see Appendix B).

The radiocarbon assays provide the chronological framework for reconstruction of the geomorphic history of the clay dunes. The assays on sediment/soil samples are on organic materials or humates extracted from the samples. The organic matter in sediments is detrital, having been deposited with the clastic sediments. Therefore, the radiocarbon assays provide approximate ages of deposition. The humates in soils, however, represent organic matter that was produced on stable surfaces and then translocated through illuviation into the subsurface, where it is bound by clays. The assays thus represent estimates of mean residence time (MRT) and provide a reliable measure only of minimum age (see Stein 1992: 202-203). All radiocarbon age calculations are based on a 5,568-year half-life for ${ }^{14} \mathrm{C}$. All assays have been corrected for carbon isotope fractionation, and their $\delta^{13} \mathrm{C}$ values are presented. Calibration factors based on the 20-year atmospheric record of Pearson and Stuiver (1993) and Stuiver and Pearson (1993) have been applied to the corrected assays to provide calendrical dates.

The paleoenvironmental studies involved a preliminary pollen/phytolith analysis, conducted by J. Philip Dering of the Palynology Laboratory, Texas A\&M University (see Appendix D), and stable carbon isotope studies of past plant communities based on the $\delta^{13} \mathrm{C}$ values provided by Beta Analytic, Inc. on the soil humate samples. The buried organic-rich A horizons and zones throughout the clay dunes provide an excellent opportunity for reconstruction of past plant communities through stable carbon isotope analysis. Researchers have argued that increases in $\delta^{13} \mathrm{C}$ values provide a measure of change in $\mathrm{C}_{4}$ versus $\mathrm{C}_{3}$ plants in the overall plant community (Cerling 1984; Cerling and Hay 1986). Therefore, the $\delta^{13} \mathrm{C}$ values from soil humates should be able to assess changes between $\mathrm{C}_{3}$ and $\mathrm{C}_{4}$ plant production and biomass (Cerling et al. 1989; Dzurec et al. 1985; Haas et al. 1986; Natelhoffer and Fry 1988).

All trees and many shrubs and grasses are $\mathrm{C}_{3}$ plants, while some grasses and herbaceous plants are $\mathrm{C}_{4}$ plants. The photosynthetic pathway used and the chemical composition of the carbon molecules produced differ between $\mathrm{C}_{3}$ and $\mathrm{C}_{4}$ plants. Plants of the $\mathrm{C}_{3}$ group utilize the CalvinBenson photosynthetic pathway, which produces a three-carbon molecule (phosphoglycerate), while $\mathrm{C}_{4}$ plants utilize the Hatch-Slack pathway, with a four-carbon molecule (oxaloacetate, aspartate, or malate) as the first stable product of $\mathrm{CO}_{2}$ fixation. The Calvin-Benson pathway is more "primitive" (Smith and Robbin 1974), while the Hatch-Slack pathway has developed relatively recently, probably in reaction to decreasing amounts of $\mathrm{CO}_{2}$ in the atmosphere (Smith 1976). 
During photosynthesis, a plant utilizes $\mathrm{CO}_{2}$ consisting of either ${ }^{13} \mathrm{C}$ or ${ }^{12} \mathrm{C}$. Unlike ${ }^{14} \mathrm{C}$, these two isotopes of carbon are stable and do not decay, and they are readily available in the atmosphere. Because of slight weight differences in the two stable carbon isotopes, ${ }^{13} \mathrm{C}$ being heavier due to an extra neutron, the two photosynthetic pathways utilize ${ }^{13} \mathrm{C}$ and ${ }^{12} \mathrm{C}$ in slightly different ratios. The $\mathrm{C}_{3}$ and $\mathrm{C}_{4}$ pathways use the same basic photosynthetic processes; however, the $\mathrm{C}_{4}$ pathway has additional steps which allow it to efficiently use more of the available carbon (in the form of $\mathrm{CO}_{2}$ ). The $\mathrm{C}_{3}$ pathway utilizes less of the available carbon because it discriminates more against ${ }^{13} \mathrm{C}$ (Vogel 1980). This difference has two effects on $\mathrm{C}_{4}$ plants. First, $\mathrm{C}_{4}$ plants are more resistant to water stress, high temperatures, and high irradiances but less tolerant of cold temperatures, especially minimum temperatures during the growing season (Tieszen and Imbamba 1980). Consequently, $\mathrm{C}_{3} / \mathrm{C}_{4}$ plant ratios reflect past and present climatic conditions such as mean annual temperatures and precipitation (see Cerling and Hay 1986; Livingston and Clayton 1980; Teeri and Stowe 1976). Second, ${ }^{13} \mathrm{C}$ is relatively more common in $\mathrm{C}_{4}$ than in $\mathrm{C}_{3}$ plants, rendering the isotopic difference between $\mathrm{C}_{3}$ and $\mathrm{C}_{4}$ plants measurable by mass spectrometer. Plants in a third group, Crassulacean acid metabolism (CAM) plants which include most succulents, have the ability to operate as $\mathrm{C}_{3}$ or $\mathrm{C}_{4}$ plants depending on the environmental conditions. The most common CAM plants in South Texas-prickly pear and agaves - normally function as $\mathrm{C}_{4}$ plants (Eickmeier and Bender 1976). Therefore, this analysis groups CAM plants with $\mathrm{C}_{4}$ plants.

The measurement of carbon isotope ratios $\left(\delta^{13} \mathrm{C}\right)$ is calibrated from the ${ }^{13} \mathrm{C} /{ }^{12} \mathrm{C}$ ratio in a marine belemnite (Belemnitella americana) from the Cretaceous-age Peedee Formation of South Carolina (Craig 1953). Known as the PDB standard, this fossilized mollusc has a tremendous amount of ${ }^{13} \mathrm{C}$ in relation to ${ }^{12} \mathrm{C}$ and is used as the zero reference point for measurements of ${ }^{13} \mathrm{C} /{ }^{12} \mathrm{C}$ ratios. Most terresterial sources such as living plants have much less ${ }^{13} \mathrm{C}$, resulting in negative numbers compared to the PDB standard. The difference between the PDB standard and the ${ }^{13} \mathrm{C} /{ }^{12} \mathrm{C}$ ratio of a given sample is represented by $\delta^{13} \mathrm{C}$ and is expressed in parts per thousand $(\% o)$. For example, a $\delta^{13} \mathrm{C}$ value of $-10 \%$ with respect to the PDB standard indicates that the sample contains $1 \%$ less ${ }^{13} \mathrm{C}$ than the marine belemnite or PDB standard.

The preindustrial atmospheric $\delta^{13} \mathrm{C}$ value is estimated at $-6.0 \%$. Plants of the $\mathrm{C}_{3}$ group have much less ${ }^{13} \mathrm{C}$, and their average ${ }^{13} \mathrm{C}$ value is approximately $-27 \%$; $\mathrm{C}_{4}$ and CAM plants have more ${ }^{13} \mathrm{C}$, and their average $\delta{ }^{13} \mathrm{C}$ value is near $-13 \%$ (Cerling et al. 1989:138). In materials that incorporate both types of plants (i.e., soils, pedogenic carbonates, and bones), the $\delta^{13} \mathrm{C}$ value should range between -27 and $-13 \%$. Given no further chemical changes, known as fractionations, the specific value should reflect the relative biomass contribution of $\mathrm{C}_{3}$ and $\mathrm{C}_{4}$ plants. However, further fractionations do occur in most materials such as soils. All stable isotopes undergo fractionation due to different mass weights, which render them less likely (for heavier isotopes) or more likely (for lighter isotopes) to react with other elements. It is this process that allows meaningful stable isotope analysis.

The incorporation of carbon isotopes into plants through the process of photosynthesis is the first major fractionation step. Thus, $\mathrm{C}_{3}$ plants have fractionated the atmospheric source to a greater extent than $\mathrm{C}_{4}$ plants. As carbon isotopes pass from plants into soils, additional fractionations occur affecting the isotopic configuration. Besides the $\mathrm{C}_{3} / \mathrm{C}_{4}$ composition of the plant community, several other factors affect the isotope composition of soils: (1) variations in atmospheric $\delta^{13} \mathrm{C}$ values; (2) differential preservation of ${ }^{13} \mathrm{C}$ plant components such as holocellulose and lignin; (3) variations in soil organic inputs; (4) decomposition of organic materials; (5) illuviation; and (6) anthropogenic modifications (Cerling et al. 1989; Dzurec et al. 1985; Natelhoffer and Fry 1988). However, as explained below, only one of these variables is considered to have affected the soil humate samples in this analysis.

Data from coal derived from terrestrial plants and early Pliocene $\mathrm{C}_{3}$ and $\mathrm{C}_{4}$ grass cuticles suggest that atmospheric $\delta^{13} \mathrm{C}$ values have not changed by more than 1 or $2 \%$ since the Tertiary or earlier (Deines 1980; Nambudiri et al. 1978). Since the samples for this analysis are clearly late Holocene in age, effects from variations in the $\delta^{13} \mathrm{C}$ values of the atmosphere are considered negligible. Differential preservation of plant components could possibly affect the $\delta^{13} \mathrm{C}$ values in soils; however, 
this appears to be a factor for only short periods after the introduction of dead plant materials into a soil because the plants decompose rapidly (Dzurec et al. 1985:18; Natelhoffer and Fry 1988: 1637). Therefore, it is unlikely that differential preservation of various plant components or variations in soil organic inputs would pose a problem for soils more than 100 years old or soils isolated from introduced nondecomposed plant materials by burial (Bousman et al. 1990:93). Anthropogenic modifications of the plant community through agriculture are nonexistent, although overgrazing by cattle may have a slight effect on the modern surface soil. Effects of illuviation are regarded as insignificant because the samples were taken from near the top of the thin (ca. $10 \mathrm{~cm}$ ) humic-rich $\mathrm{A}$ horizons, which are separated by zones of relatively unweathered sand-clay parent material.

Only microbial decomposition of organic materials is regarded as having an effect on the $\delta{ }^{13} \mathrm{C}$ values of the soil humate samples. Microbial decomposition enriches the ${ }^{13} \mathrm{C}$ content of soils from the isotope values of the original plants (Cerling et al. 1989; Dzurec et al. 1985; Natelhoffer and Fry 1988). Generally, $\delta{ }^{13} \mathrm{C}$ values increase with depth in single soil solums as total carbon decreases, implying that a reduction of carbon reflects greater decomposition of soil organics (Natelhoffer and Fry 1988). Therefore, decomposition tends to increase the $\delta^{13} \mathrm{C}$ values, while organic inputs act to decrease the $\delta^{13} \mathrm{C}$ values with the introduction of plant material. Since decomposition has the final fractionation effect, this must be considered in paleoenvironmental reconstructions (Bousman et al. 1990:93).

Dzurec et al. (1985:18) and Natelhoffer and Fry (1988:1635) suggest that $a+3$ to $+4 \%$ enrichment in ${ }^{13} \mathrm{C}$ occurs due to the microbial decomposition of organic materials in soils. Soil humate $\delta^{13} \mathrm{C}$ values can be compensated for this fractionation effect, and the relative contribution of $\mathrm{C}_{3}$ versus $\mathrm{C}_{4} / \mathrm{CAM}$ plants can be calculated through the following formula (Bousman et al. 1990):

Estimated \% of $C_{3}$ Plant Biomass $=\frac{\left[\left(\delta^{13} C-3.5\right)+13\right]}{(-0.14)}$.

This formula assumes that the mean $\delta^{13} \mathrm{C}$ value for $\mathrm{C}_{3}$ plants is $-27 \%$ and the mean $\delta^{13} \mathrm{C}$ value for $\mathrm{C}_{4} / \mathrm{CAM}$ plants is $-13 \%$. It also assumes that ${ }^{13} \mathrm{C}$ enrichment of soils is $+3.5 \%$ (Bousman et al. 1990:94). However, it should be noted that there is disagreement on the mean $\delta^{13} \mathrm{C}$ values and the degree of fractionation used. For instance, Bender (1968) gives a mean value of -25 and $-12 \%$ oo $\mathrm{C}_{3}$ and $\mathrm{C}_{4}$ plants, respectively, and Tieszen et al. (1979) propose different means of -28.0 and $-12.5 \%$. The microbial decomposition degree of fractionation of $3.5 \%$ is slightly smaller than the $4.4 \%$ oo suggested by Cerling et al. (1989:138). These differences, however, only result in marginally different estimates of the $\mathrm{C}_{3} / \mathrm{C}_{4}$ plant biomass. 


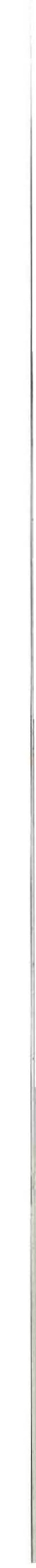




\section{RESULTS OF ARCHEOLOGICAL INVESTIGATIONS}

\section{SITE 41WY50 \\ Site Description}

Site $41 \mathrm{WY} 50$ is located on the mainland coast of the Laguna Madre on the El Sauz Ranch (Figure 6). It lies $4.4 \mathrm{~km}$ east of the drainage ditch outfall and $2.6 \mathrm{~km}$ west of Josephine Island. The elevation of the site is less than $4.5 \mathrm{~m}$ above mean sea level. It is situated on the backside remnant of a clay dune and the wave-cut or truncated windward side of the dune. Low, dense, thorny brush, including trecul yucca and prickly pear, covers the backside of the dune. Common open grassy areas are found along the erosional areas and scattered throughout the brush. The sloping, truncated, windward side of the dune is virtually barren of vegetation and is littered with drift debris. Downslope and east of this area is an active wind-tidal flat. Burned pumice, a piece of burned shell, and fish otoliths were observed eroding out of the erosional scarp of the dune and onto the truncated windward side. Site boundaries measure approximately $90-100 \mathrm{~m}$ along the northsouth axis of the dune and $20-30$ m east-west.

\section{Previous Investigations}

Site 41 WY 50 was recorded by Day et al. (1981) during a survey of the Hidalgo-Willacy Drainage Ditch outfall area. Surface cultural materials were observed along 100-125 m of the eastern erosional face of the clay dune. These consisted of the upper portion of a human cranium, five long bone fragments, two marine shell fragments (one with edge damage), seven fish otoliths, and several marine and terrestrial gastropods.
A subsurface probe measuring $150 \times 60 \mathrm{~cm}$ was placed on top of the dune over the burial at the edge of the erosional scarp. It was excavated to a depth of $180 \mathrm{~cm}$ below the ground surface. The human burial was removed from between 112 and $133 \mathrm{~cm}$, along with several modified bone fragments and canid teeth. Two shallow, basin-shaped hearths also were encountered. Both consisted of charcoal flecks, ashy sediments, and a few burned clay lumps. The excavated profile revealed 15 natural strata, consisting of brown to grayish brown clays and silts that became increasingly sandier down-profile.

A sample of the human bone was radiocarbon dated to $540 \pm 110$ B.P. (Prewitt 1981:413). However, this assay was on bone apatite, and it was not corrected for the effects of carbon isotope fractionation. A sample of collagen from the bones was later assayed and yielded a $\delta^{13} \mathrm{C}$-corrected age of $1415 \pm 140$ B.P. (Bousman et al. 1990:99).

\section{Work Accomplished}

The current investigations at site 41WY50 included hand excavation of nine $1-x-1-m$ test units; mechanical excavation of 11 backhoe trenches; collection of 82 sediment samples for radiocarbon assays, grain-size and soluble salts analyses, and pollen/phytolith analysis; and site mapping.

The depths of the test units ranged from $100 \mathrm{~cm}$ in Test Unit 9 to $150 \mathrm{~cm}$ in Test Unit 8 . The 11 backhoe trenches ranged in length from 7.6 to $21.3 \mathrm{~m}$, with the mean being $10.6 \mathrm{~m}$, and in depth from 1.3 to $2.4 \mathrm{~m}$, with the mean being $1.6 \mathrm{~m}$. Nine of the 11 trenches (Backhoe Trenches 1-9) were excavated from the erosional east face of the dune to the western backslope perpendicular 


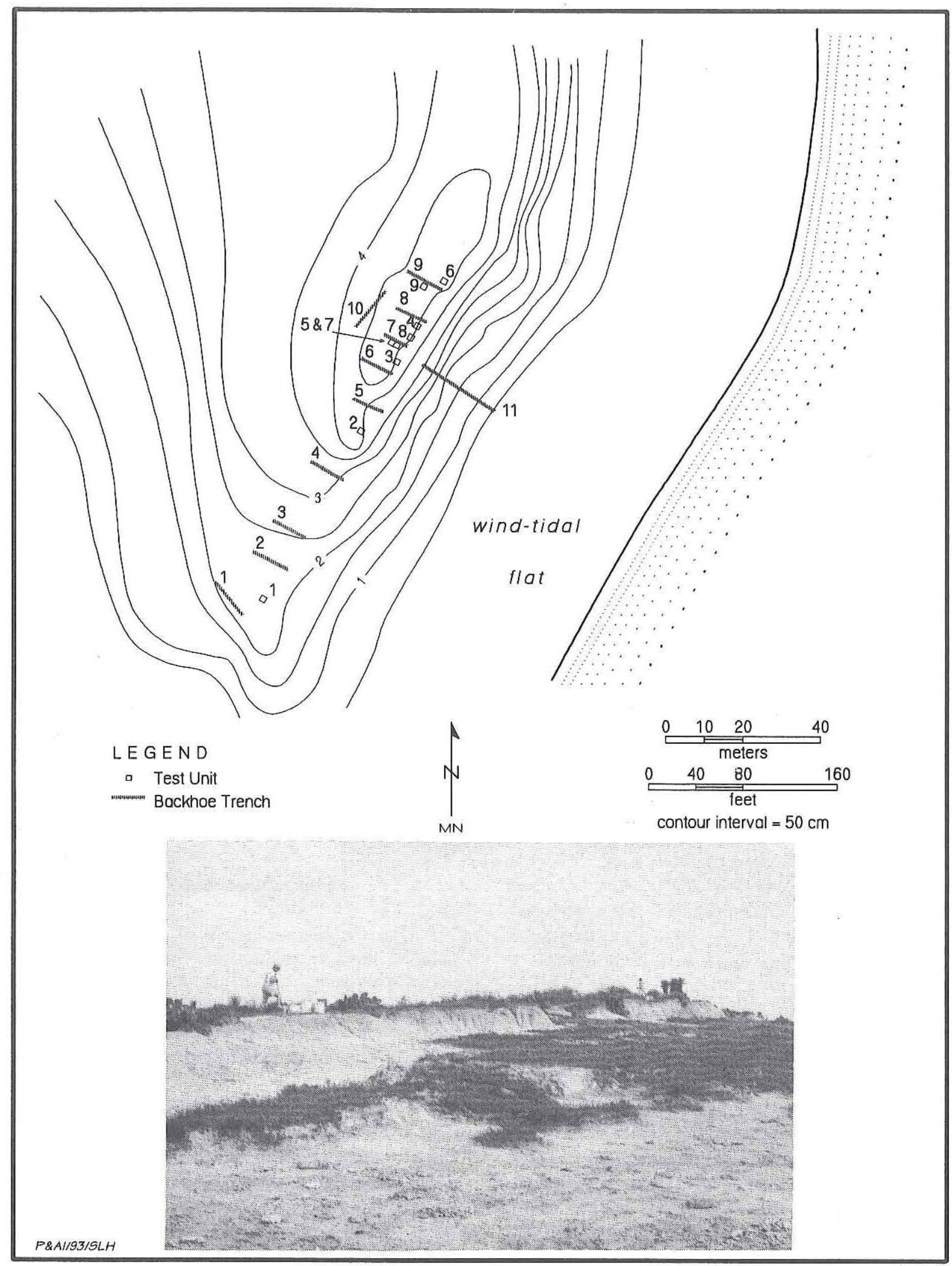

Figure 6. Site map and photograph, 41WY50; photograph is facing north along the windward side of the dune. 
to the long axis of the dune. Backhoe Trench 10 ran parallel to the long axis of the dune, west of Backhoe Trenches 7 and 8. Backhoe Trench 11 was placed on the truncated dune surface, running west to east from the erosional dune face to the wind-tidal flat. Eight localities or profiles in seven of the trenches were described in detail (see Appendix A). One wall along the length of each of five backhoe trenches (Backhoe Trenches 2, 7-9, and 11) was completely profiled.

Of the 82 sediment samples collected for various analyses, 8 were submitted for radiocarbon dating, 35 for grain-size analysis, 5 for soluble salts analysis, and 1 for pollen/phytolith analysis. The fill collected from Features 1, 3, 10, and 11 was floated, and charcoal was extracted for radiocarbon dating; unfortunately, these charcoal samples were lost en route to Beta Analytic, Inc. Two samples of feature fill from Features 3 and 10 also were analyzed for pollen and phytoliths. Two small blocks of sediment and feature fill were cut from Features 9 and 10 for micromorphological analysis (see Appendix E).

Site mapping was completed with a transit and metric stadia rod. Two permanent datums were set in concrete and stamped with the site number and date. One datum was labeled "Baseline datum," and the other was labeled "Hub A."

\section{Materials Recovered}

The cultural affiliation of the materials recovered from site 41 WY 50 is extremely tenuous. Definite artifacts such as lithics, ceramics, worked shells, or modified or burned bones were not recovered. The materials that were recovered consist of 270 faunal remains and 20 gravel- and pebble-sized pieces of pumice (Table 1). The faunal remains include elements of turtle, fish, rodents, and bird (see Appendix C). Many of the skeletal elements are small and fragmentary, but surprisingly, over $70 \%$ are identifiable. Most of the faunal remains $(n=202)$ were recovered from the upper levels (1-5) of the test units, proveniences that are well above any cultural feature. Only 18 specimens are associated with a feature (Feature 3); however, they are not burned, cut marks are not evident, and only 1 specimen is identifiable.

Most of the 20 pieces of pumice were recovered from Level 1 of the test units. Four pieces appear to be burned but are not associated with a feature, although one piece is associated with two charcoal chunks in Level 1 of Test Unit 6. Because pumice floats, it commonly is deposited by tidal storm surges on the wind-tidal flats and clay dunes of the south Texas coast.

TABLE 1

FAUNAL REMAINS AND PIECES OF PUMICE RECOVERED, 41WY50*

\begin{tabular}{|c|c|c|c|c|c|c|c|c|c|}
\hline Level $(\mathrm{cm})$ & TU 1 & TU 2 & TU 3 & TU 4 & TU 5 & TU 6 & TU 7 & TU 8 & TU 9 \\
\hline $0-10$ & - & - & $1 \mathrm{P}$ & $13 \mathrm{P}$ & - & $4 \mathrm{P}$ & - & - & $68 \mathrm{~F}$ \\
$10-20$ & $1 \mathrm{~F}$ & - & - & $1 \mathrm{P}$ & $5 \mathrm{~F}$ & - & $36 \mathrm{~F}$ & - & - \\
$20-30$ & - & - & - & - & $31 \mathrm{~F}, 1 \mathrm{P}$ & - & $8 \mathrm{~F}$ & $1 \mathrm{~F}$ & - \\
$30-40$ & $2 \mathrm{~F}$ & - & - & - & $29 \mathrm{~F}$ & - & $1 \mathrm{~F}$ & - & - \\
$40-50$ & - & - & - & - & $20 \mathrm{~F}$ & - & - & - & - \\
$50-60$ & - & - & - & $1 \mathrm{~F}$ & $1 \mathrm{~F}$ & - & $17 \mathrm{~F}$ & - & - \\
$60-70$ & - & - & - & - & $20 \mathrm{~F}$ & - & - & - & - \\
$70-80$ & $4 \mathrm{~F}$ & - & - & - & $18 \mathrm{~F}$ & - & - & - & - \\
$80-90$ & - & - & - & - & - & - & - & - & - \\
$90-100$ & - & - & - & - & - & - & - & - & - \\
$100-110$ & - & - & - & - & - & $1 \mathrm{~F}$ & - & - & $\mathrm{x}$ \\
$110-120$ & - & - & - & - & - & - & - & - & $\mathrm{x}$ \\
$120-130$ & $\mathrm{x}$ & - & - & - & $\mathrm{x}$ & - & $\mathrm{x}$ & - & $\mathrm{x}$ \\
$130-140$ & $\mathrm{x}$ & $\mathrm{x}$ & - & - & $\mathrm{x}$ & - & $\mathrm{x}$ & - & $\mathrm{x}$ \\
$140-150$ & $\mathrm{x}$ & $\mathrm{x}$ & $\mathrm{x}$ & $\mathrm{x}$ & $\mathrm{x}$ & $\mathrm{x}$ & $\mathrm{x}$ & - & $\mathrm{x}$ \\
\hline
\end{tabular}


Therefore, its occurrence cannot be associated with human activities in the area with any confidence.

\section{Features}

Ten cultural features were encountered at 41 WY50 within the backhoe trench profiles and test units. One additional feature, Feature 4, was found to be a rodent/tortoise burrow or den and therefore is not discussed further. Most of the features occur within organic-rich A horizons or lenses, making feature designation and feature boundaries difficult to define. These organic-rich zones represent old sloping surfaces or soils on the leeward side of the dune. Often the dip of the features is dictated by the slope of the old surface.

Features $1,3,10$, and 11 were completely or partially excavated. With the exception of Feature 11, all are small, shallow, basin-shaped hearths. The feature fill consists mainly of small pieces of charcoal, ashy sediments, and some oxidized sediments. Surprisingly, burned clay lumps, which are fairly common in small hearth features of the region, were absent (cf. Headrick 1991; Hester 1971; Smith 1982). Burned clay lumps are considered to be natural products of the intense heat or fire within the shallow earthen basins (Corbin 1963; Huebner 1986). The absence of burned clay lumps suggests that the fires were not intense, probably fueled by grass, and/or the utilization of the hearths was for only a very short period of time.

\section{Feature 1}

Feature 1 was exposed in the south wall of Backhoe Trench 9 and excavated by Test Unit 9 (Figure 7). The feature is a shallow, basin-shaped hearth, which when first exposed in the backhoe trench wall measured $40 \mathrm{~cm}$ east-west, but upon further excavation, the feature was found to be $47 \mathrm{~cm}$ east-west, at least $14 \mathrm{~cm}$ north-south, and $4-5 \mathrm{~cm}$ thick. The top of the feature is at 72$73 \mathrm{~cm}$ below the ground surface at Test Unit 9 . Feature 1 was probably circular to oval in plan view. The fill consists of charcoal flecks and ashy sediment. Feature boundaries range from distinct to diffuse, with clearer boundaries at the east end of the feature.

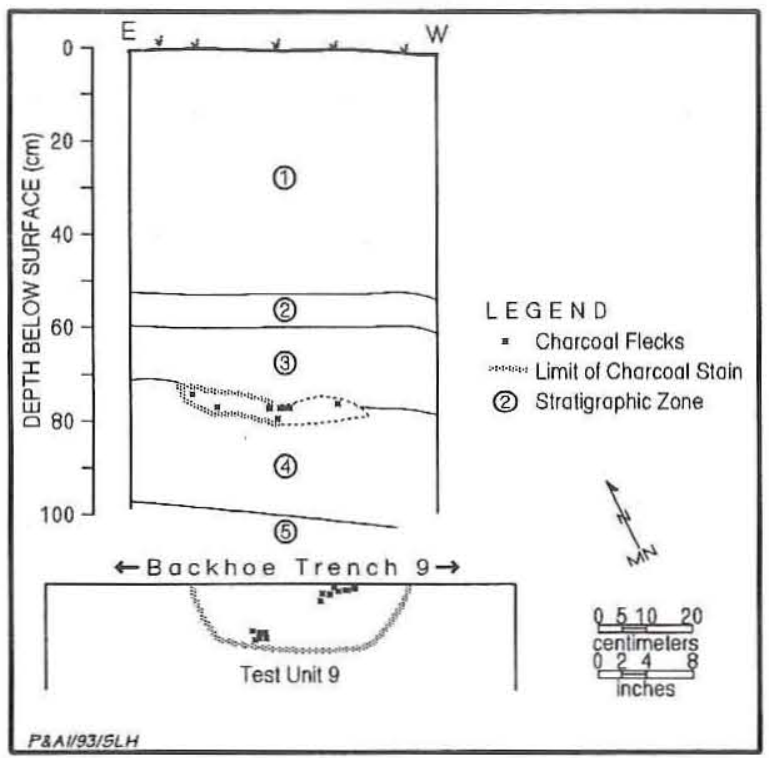

Figure 7. Profile of Feature 1 in south wall of Backhoe Trench 9 and plan of Feature 1 in Test Unit 9, 41WY50.

\section{Feature 2}

Feature 2 was exposed in the south wall of Backhoe Trench 8. It was not excavated but is documented through its cross-section exposure in the trench profile. Feature 2 is a shallow, basinshaped hearth, measuring $55 \mathrm{~cm}$ east-west and $2.0-5.5 \mathrm{~cm}$ thick. The top of the feature is at 86$94 \mathrm{~cm}$ below the ground surface. The feature fill consists of charcoal flecks and ashy sediment.

\section{Feature 3}

Feature 3 was exposed in the south wall of Backhoe Trench 7 and excavated by Test Units 5 and 7 (Figure 8). Feature 3 is a shallow, basinshaped hearth, which when first exposed in the backhoe trench wall measured $63 \mathrm{~cm}$ long; however, upon further excavation, the feature was found to be $104 \mathrm{~cm}$ long, at least $44 \mathrm{~cm}$ wide, and $3-5 \mathrm{~cm}$ thick. The top of the feature is 62 to $79 \mathrm{~cm}$ below the ground surface at Test Unit 5 . Feature 3 was probably oval shaped to amorphous in plan view. The feature fill consists of charcoal chunks and flecks, charcoal-stained sediments, and ashy sediments. The eastern half of the feature is discrete and dips to the west, while the western half is less discrete. Eighteen faunal specimens were recovered from the feature, only one of which is identifiable (cf. Texas gopher tortoise). None are burned, and they reveal several gnaw marks. 


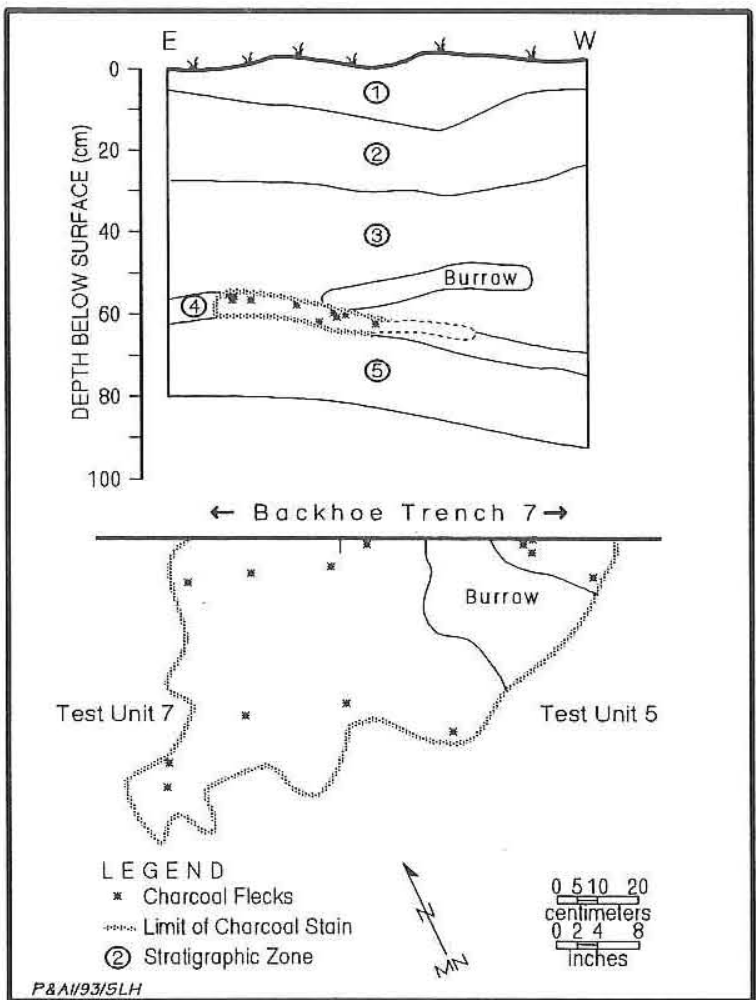

Figure 8. Profile of Feature 3 in south wall of Backhoe Trench 7 and plan of Feature 3 in Test Units 5 and 7, 41 WY50.

They are considered to be intrusive since a burrow (Feature 4) overlies and cuts across the central basin of Feature 3. Considering the large size of the burrow and the burrowing nature of the Texas gopher tortoise, the disturbance may be attributed to this reptile.

\section{Feature 5}

Feature 5 was exposed in the north wall of Backhoe Trench 6 (Figure 9). It was not excavated but is documented through its cross-section exposure in the wall of the trench. The feature is an undulating lens, $1-2 \mathrm{~cm}$ thick and $57 \mathrm{~cm}$ long, of charcoal flecks and ashy sediment covered in spots by a thin $(<1 \mathrm{~cm})$ layer of eolian sediments. The top of the feature is $67-71 \mathrm{~cm}$ below the ground surface. Heavy concentrations of charcoal flecks occur in the center of the feature and become thinly dispersed along the outer portions. The feature may represent a simple surface fire rather than a prepared-basin fire hearth.

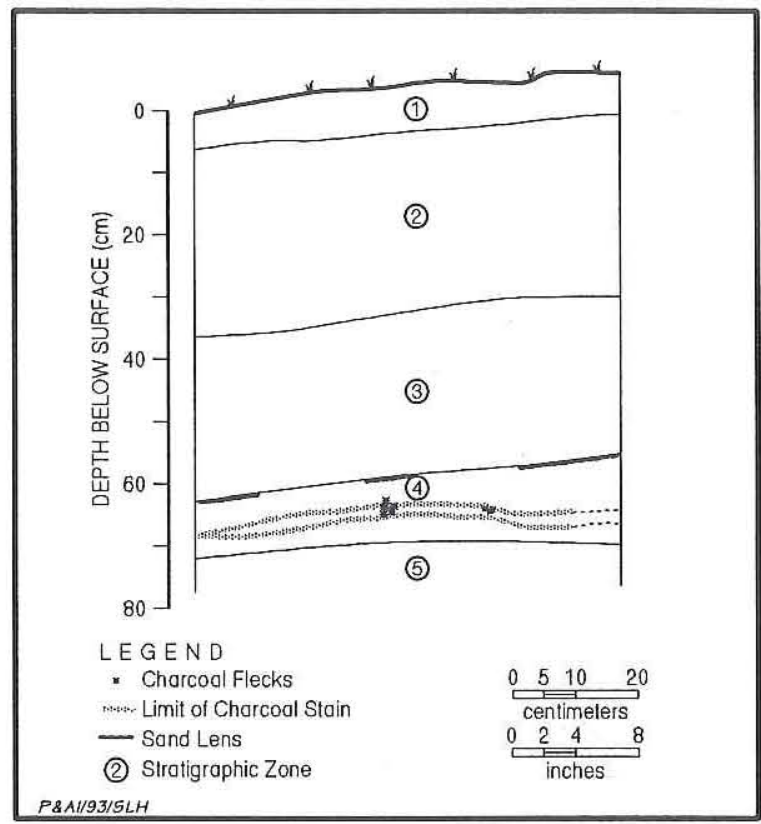

Figure 9. Profile of Feature 5 in north wall of Backhoe Trench 6, 41WY50.

\section{Feature 6}

Feature 6 was exposed in the south wall of Backhoe Trench 5. It was not excavated but is documented through its cross-section exposure in the trench wall. Feature 6 is a $28-\mathrm{cm}-$ long, 2-cm-thick lens of charcoal flecks and ashy sediment covered by a thin $(<1 \mathrm{~cm})$ layer of eolian silts and sands. The top of the feature is 81$82 \mathrm{~cm}$ below the ground surface. Its boundaries are slightly diffuse but discernible.

\section{Feature 7}

Feature 7 was exposed in the north wall of Backhoe Trench 4 (Figure 10). It was not excavated but is documented through its crosssection exposure in the wall of the trench. Feature 7 is a shallow, basin-shaped hearth $33 \mathrm{~cm}$ long and $1-4 \mathrm{~cm}$ thick. The top of the feature is 177$185 \mathrm{~cm}$ below the ground surface. Oxidized sediment forms the bottom of the basin underlying charcoal flecks and chunks and ashy sediments. Charcoal and ashy sediment also occur outside the basin to the west, possibly representing fill that was cleaned out of the basin by human or possibly other agents. 


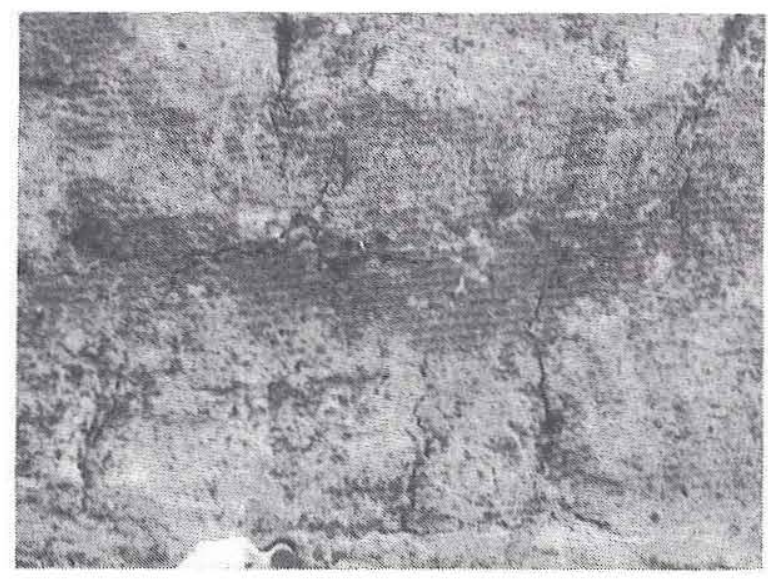

Figure 10. View of Feature 7 in north wall of Backhoe Trench 4, 41WY50.

\section{Feature 8}

Feature 8 was exposed in the north wall of Backhoe Trench 3 (Figure 11). It was not excavated but is documented through its crosssection exposure in the wall of the trench. Feature 8 is a shallow, basin-shaped hearth, 0.5 to $3.0 \mathrm{~cm}$ thick and $41 \mathrm{~cm}$ long, that gently dips to the west. The top of the feature is $102-108 \mathrm{~cm}$ below the ground surface. The feature fill consists of a concentration of charcoal, ashy sediment, and a few patches of oxidized sediment in the eastern half.

\section{Feature 9}

Feature 9 was exposed when the balk between Test Unit 3 and the erosional face of the clay dune was removed to facilitate the excavation of Test Unit 3 (Figure 12). It was not excavated but is documented through its cross-section exposure in the south wall of the removed balk. Feature 9 is a shallow, basin-shaped hearth, $3-5 \mathrm{~cm}$ thick and $45 \mathrm{~cm}$ long (east-west). The top of the feature is $96-100 \mathrm{~cm}$ below the ground surface at Test Unit 3. The feature fill consists of charcoal flecks and chunks and ashy sediment, covered by a thin layer of eolian silt and sand. A small block was cut out of the cross-section profile of the feature for micromorphological analysis (see Appendix E). Under microscopic examination, the thin-sectioned block revealed

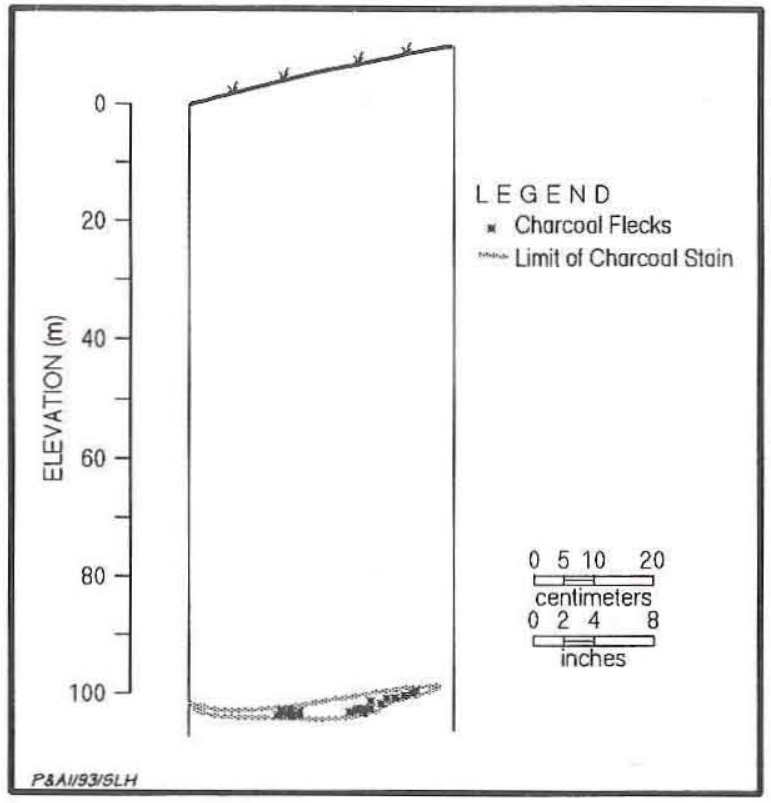

Figure 11. Profile of Feature 8 in north wall of Backhoe Trench 3, 41WY50.

wood charcoal and oxidized sediments representing in situ burning.

\section{Feature 10}

Feature 10 was encountered during the excavation of Test Unit 8 (Figure 13). The feature extends out of the south wall of Test Unit 8 and therefore was only partially exposed in plan view during excavation. Feature 10 is a shallow, basinshaped hearth which is probably circular in plan view. It measures $50 \mathrm{~cm}$ east-west and at least $12 \mathrm{~cm}$ north-south and is $1-4 \mathrm{~cm}$ thick. The top of the feature is $85-90 \mathrm{~cm}$ below the ground surface at Test Unit 8. The feature fill consists of charcoal flecks and chunks and some oxidized sediments. A small block was cut out of the cross-section profile of the feature for micromorphological analysis (see Appendix E). Under microscopic examination, the thin-sectioned block revealed a lens of grass charcoal, phytoliths, and oxidized sediments representing in situ burning.

\section{Feature 11}

Feature 11 was encountered during the excavation of Test Unit 8. (Figure 14). It extends 


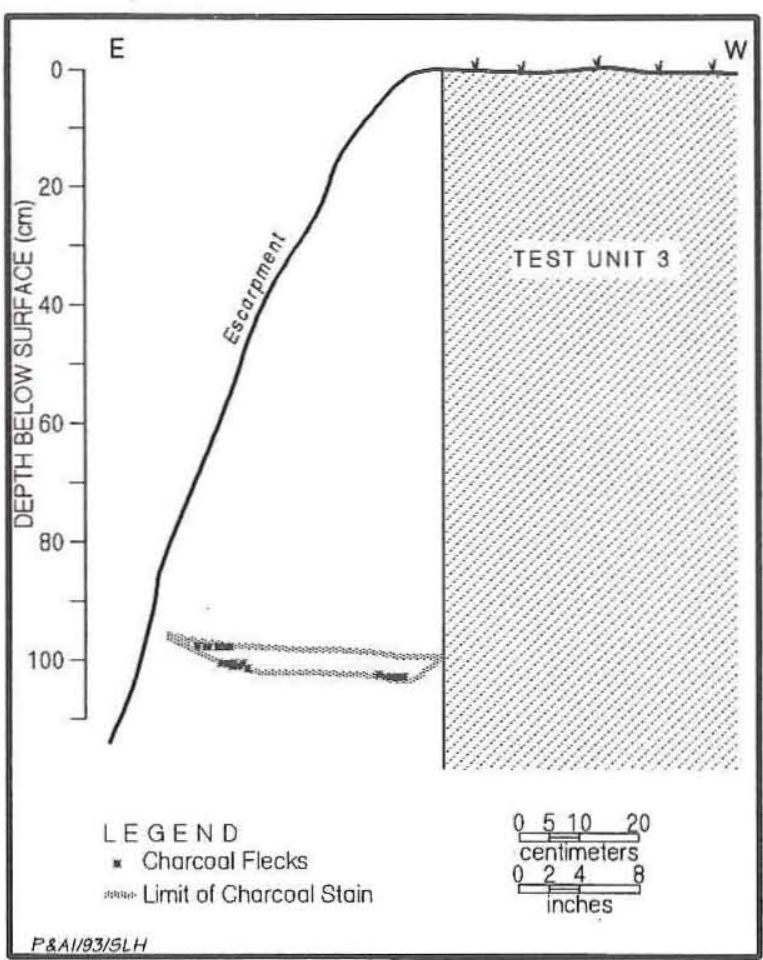

Figure 12. Profile of Feature 9, 41WY50.

out of the east wall of the unit and therefore was only partially exposed in plan view during excavation. Feature 11 appeared to be a pit feature when first encountered at $115 \mathrm{~cm}$ below the surface in the eastern half of the unit. The exposed portion was semicircular in shape, measuring $80 \mathrm{~cm}$ north-south and at least $35 \mathrm{~cm}$ east-west. Its fill was darker than the surrounding sediments and contained common pieces of charcoal. Test Unit 8 is adjacent to and west of the location of the human burial that was exhumed by Day et al. (1981). It was first believed that Feature 11 might represent the edge of the original burial pit or a separate burial pit. The semicircular feature became larger in size with depth but disappeared at approximately $122 \mathrm{~cm}$ below the surface. Excavation continued to $150 \mathrm{~cm}$ below the surface, but nothing was encountered.

\section{Sediments and Stratigraphy}

The sediments and stratigraphy at 41WY50 were observed and documented from nine localities along seven backhoe trenches. A chronological framework for the geomorphology of the site is provided by seven radiocarbon assays from sediment samples (Table 2). Observations reveal

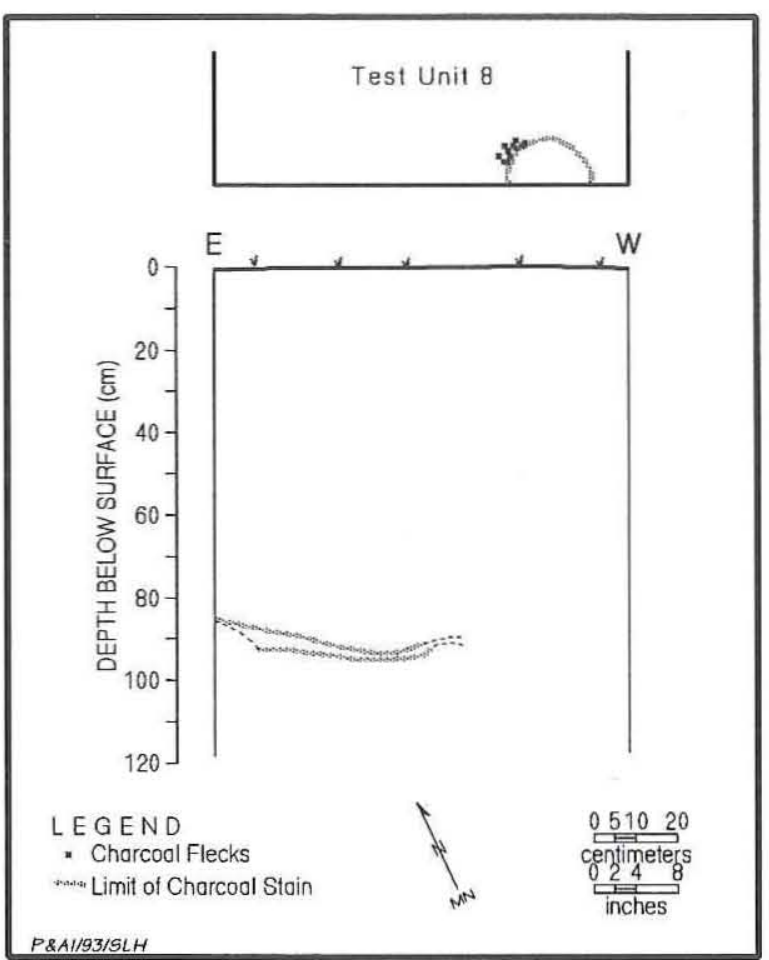

Figure 13. Plan of Feature 10 in Test Unit 8 at $90 \mathrm{~cm}$ below the ground surface and profile of Feature 10 in south wall of Test Unit 8, 41WY50.

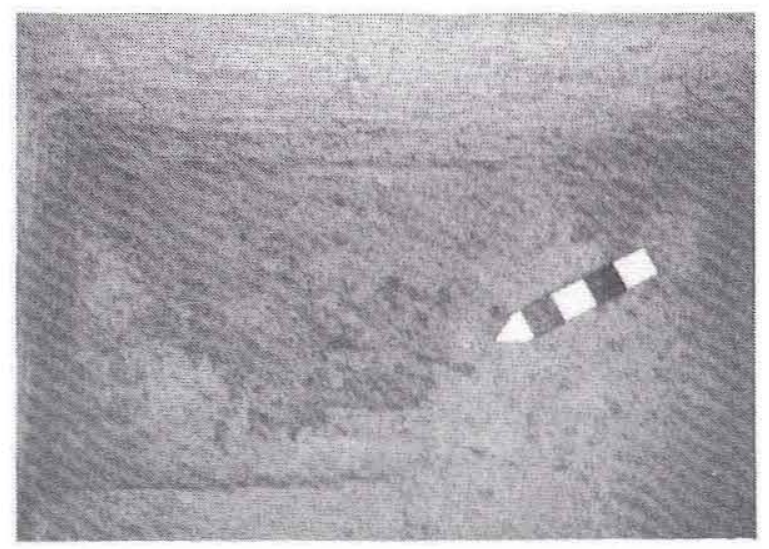

Figure 14. Plan view of Feature 11, 41 WY50.

that site $41 \mathrm{WY} 50$ sits on an eolian dune consisting mainly of sand and clay overlying the late Pleistocene Beaumont Formation. Only the leeward side of the clay dune is preserved, while the windward side has been truncated. The dune contains many buried but weakly developed soils with thin mollic epipedons. The modern surface soil is an Aridisol grading into an Ustoll (Mollisol) that belongs to the Lalinda soil series (Turner 1982). Lalinda soils are classified as Ustollic 


\begin{tabular}{|c|c|c|c|c|}
\hline \multicolumn{5}{|c|}{ TABLE 2} \\
\hline Lab No. & Provenience & $\begin{array}{l}\text { Uncorrected } \\
\text { Age B.P. }\end{array}$ & $\begin{array}{l}\text { Corrected Age } \\
\text { B.P.* }\end{array}$ & $\begin{array}{l}\text { Calibrated Age/Date (Intercepts } \\
\text { and One-Sigma Range) }{ }^{* *}\end{array}$ \\
\hline Beta-61897 & $\begin{array}{l}\text { Backhoe Trench 11c } \\
61-71 \mathrm{~cm}\end{array}$ & $2520 \pm 60$ & $2690 \pm 60(-15.0)$ & $\begin{array}{l}2847(2770) 2753 \text { B.P. } \\
897(820) 803 \text { B.C. }\end{array}$ \\
\hline Beta-61898 & $\begin{array}{l}\text { Backhoe Trench 11c } \\
23-33 \mathrm{~cm}\end{array}$ & $2150 \pm 90$ & $2320 \pm 90(-14.0)$ & $\begin{array}{l}2358(2340) 2197 \text { B.P. } \\
408 \text { (390) } 247 \text { B.C. }\end{array}$ \\
\hline Beta-61899 & $\begin{array}{l}\text { Backhoe Trench } 11 \mathrm{~b} \\
111-121 \mathrm{~cm}\end{array}$ & $2650 \pm 90$ & $2810 \pm 100(-15.0)$ & $\begin{array}{l}3062(2880) 2781 \text { B.P. } \\
1112(930) 831 \text { B.C. }\end{array}$ \\
\hline Beta-61900 & $\begin{array}{l}\text { Backhoe Trench 11a } \\
23-31 \mathrm{~cm}\end{array}$ & $1020 \pm 60$ & $1180 \pm 60(-15.4)$ & $\begin{array}{l}1168(1070) 988 \text { B.P. } \\
\text { A.D. } 782(880) 962\end{array}$ \\
\hline Beta-61901 & $\begin{array}{l}\text { Backhoe Trench } 8 \\
72-79 \mathrm{~cm}\end{array}$ & $1030 \pm 70$ & $1200 \pm 70(-14.3)$ & $\begin{array}{l}1223(1080) 994 \text { B.P. } \\
\text { A.D. } 727(870) 956\end{array}$ \\
\hline Beta-61902 & $\begin{array}{l}\text { Backhoe Trench 11c } \\
35-43 \mathrm{~cm}\end{array}$ & $1100 \pm 70$ & $1260 \pm 80(-15.4)$ & $\begin{array}{l}1280(1170) 1067 \text { B.P. } \\
\text { A.D. } 670(780) 883\end{array}$ \\
\hline Beta-61903 & $\begin{array}{l}\text { Backhoe Trench } 2 \\
24-35 \mathrm{~cm}\end{array}$ & $\begin{array}{l}101.2 \pm 0.7 \% \\
\text { modern }\end{array}$ & $80 \pm 60(-14.1)$ & $\begin{array}{l}262(0) 0 \text { B.P. } \\
\text { A.D. } 1688(1950) 1955\end{array}$ \\
\hline
\end{tabular}

Camborthids, Aridisols with cambic horizons and dry, thin mollic epipedons and/or gypsic or calcic horizons below the cambic horizon (Buol et al. 1980:253, 264). The epipedon or surface horizon is usually a dark grayish brown to grayish brown sandy clay loam to sandy loam. Subsurface horizons consist of grayish brown sandy clay loams to clays.

General descriptions and geomorphic interpretations of five of the nine localities documented in the backhoe trenches are presented here (Figure 15). More-detailed descriptions of the sediments and stratigraphy of all nine backhoe trench localities can be found in Appendix A.

Backhoe Trench 2 was excavated on the preserved leeward side of the dune from the erosional face westward. It was excavated to a depth of $189 \mathrm{~cm}$, and 10 zones were identified and described from the east end of the trench. Zone 1 $(0-7 \mathrm{~cm})$ is a massive grayish brown sandy loam and is classified as a $\mathrm{Cu}$ horizon. Zones 2 and 3 $(7-59 \mathrm{~cm})$ represent a buried soil. Zone 2 is a 39-cm-thick dark gray clay loam with moderate medium subangular blocky structure. Soil humates at $24-35 \mathrm{~cm}$ below surface in this $2 \mathrm{Ab}$ horizon yielded a $\delta^{13} \mathrm{C}$-corrected radiocarbon assay of $80 \pm 60$ B.P. Zone 3 is a $13-\mathrm{cm}$-thick grayish brown clay with moderate medium subangular blocky structure. Zone 3 is a $2 \mathrm{Bb}$ horizon. Zone $4(59-95 \mathrm{~cm})$ is a massive grayish brown clay loam and represents the parent material of the overlying soil. Filaments of $\mathrm{CaCO}_{3}$ are common and increase in number down-profile. Zone 4 is classified as a $2 \mathrm{Ck}$ horizon. Zone $5(95-103 \mathrm{~cm})$ is a massive light gray clay loam. A thin $(3 \mathrm{~cm})$ discontinuous sandy lens is present at the top of the zone. Other sandy lenses were observed in the other backhoe trenches at similar elevations and may represent storm washover fans or deposits. Zone 5 is a $2 \mathrm{Cu}$ horizon. Zone $6(103-129 \mathrm{~cm})$ is a weakly developed buried soil consisting of a light brownish gray clay with weak medium subangular blocky structure. Zone 6 is a $3 \mathrm{AC}$ horizon. Zone $7(129-147 \mathrm{~cm})$ is another weakly developed buried soil. It is a structureless grayish brown sandy clay loam. Thin sand lenses are common throughout the zone. Zone 7 is classified as a $4 \mathrm{AC}$ horizon. Zone $8(147-163 \mathrm{~cm})$ repre- 


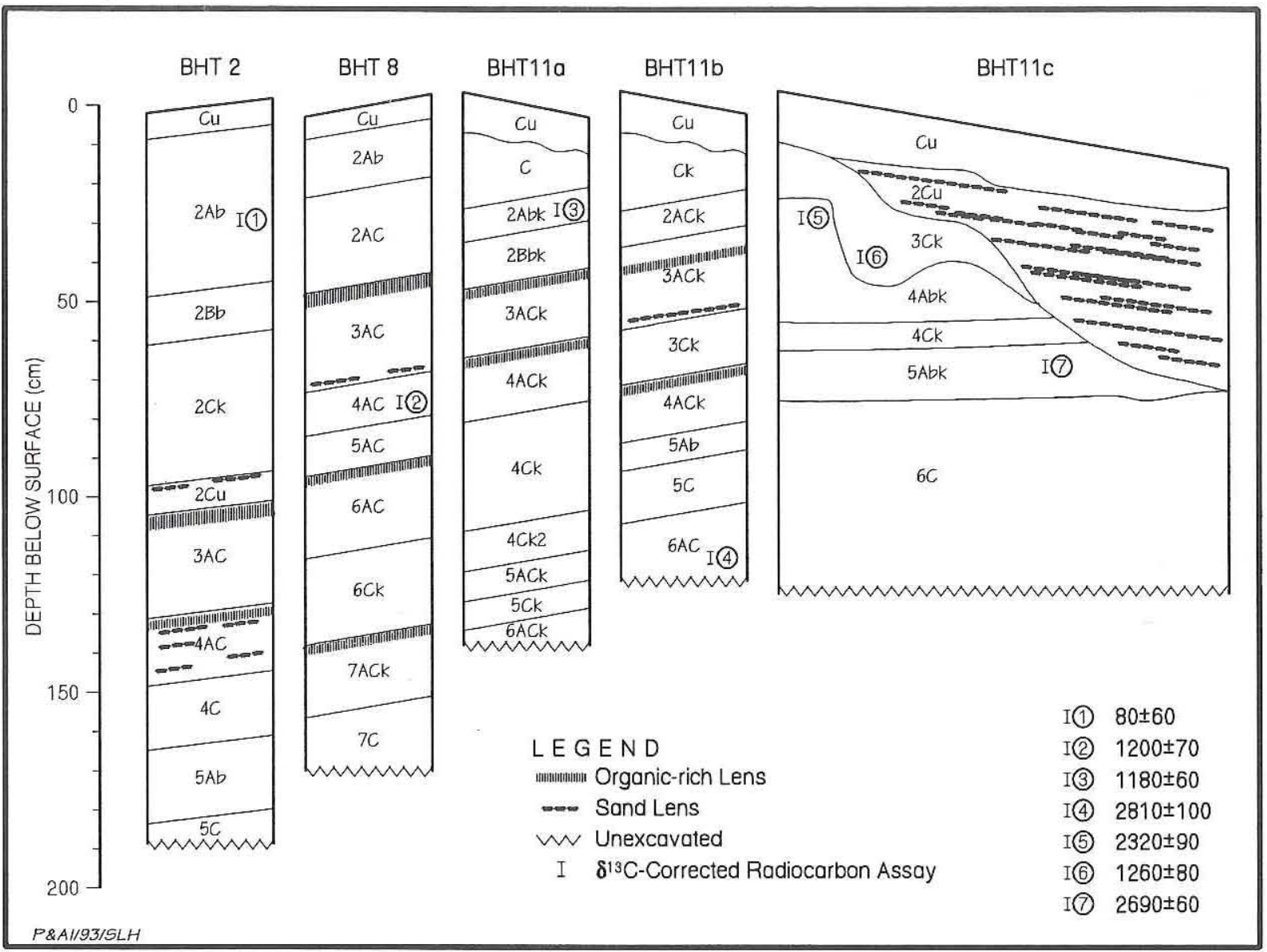

Figure 15. Profiles of Backhoe Trenches 2 and 8 and Backhoe Trench Localities 11a, 11b, and 11c, 41WY50.

sents the parent material of the overlying soil. It consists of a massive grayish brown loam and is classified as a $4 \mathrm{C}$ horizon. Zone $9(163-181 \mathrm{~cm})$ is a weakly developed buried soil (5Ab horizon). It is a dark grayish brown clay loam with weak medium subangular blocky structure. Zone 10 $(181-189+\mathrm{cm})$ is a light brownish gray to pale brown clay loam. Zone 10 is a $5 \mathrm{C}$ horizon.

Four buried soils are represented in the profile of Backhoe Trench 2. Each soil represents an interval of surface stability. The strongest developed soil is the most recent one (Zones 2 and 3 ), suggesting that earlier periods of stability were much shorter in duration.

Backhoe Trench 8 is north of Backhoe Trench 2 and was excavated on the preserved leeward side of the dune from the erosional face westward. It was excavated to a depth of $170 \mathrm{~cm}$, and 10 zones were identified and described from the east end of the trench. Zone $1(0-6 \mathrm{~cm})$ is a massive grayish brown sandy clay loam and is a $\mathrm{Cu}$ horizon. Zones 2 and $3(6-45 \mathrm{~cm})$ are a buried soil (2Ab and $2 \mathrm{AC}$ horizons). Zone 2 is a $15-\mathrm{cm}$-thick dark grayish brown clay loam with moderate medium subangular blocky structure. Zone 3 is a $24-\mathrm{cm}$-thick structureless grayish brown clay loam. Zone 4 $(45-71 \mathrm{~cm})$ is a weakly developed buried soil (3AC horizon). It is a structureless grayish brown clay loam. Three thin $(1 \mathrm{~cm})$ sandy lenses are present at the bottom of the zone. Other sandy lenses were observed in other backhoe trenches at similar elevations and may represent storm washover fans or deposits. Zones 5-7 (71$114 \mathrm{~cm})$ represent three other weakly developed buried soils. Zone 5 is a $10-\mathrm{cm}$-thick $4 \mathrm{AC}$ horizon consisting of a structureless dark gray clay loam. Feature 2 is located within this zone. Soil humates from Zone 5 yielded a $\delta{ }^{13} \mathrm{C}$-corrected radiocarbon assay of $1200 \pm 70$ B.P. Zone 6 is an $11-\mathrm{cm}$-thick grayish brown clay loam with 
moderate fine subangular blocky structure. It is classified as a $5 \mathrm{AC}$ horizon. Zone 7 is a $22-\mathrm{cm}-$ thick grayish brown clay loam with moderate medium subangular blocky structure. Zone 7 is classified as a $6 \mathrm{AC}$ horizon. Zone $8(114-135 \mathrm{~cm})$ represents the parent material of the overlying soil. It is a massive grayish brown sandy clay loam with common soft $\mathrm{CaCO}_{3}$ nodules and filaments. It is a $6 \mathrm{Ck}$ horizon. Zone $9(135-153 \mathrm{~cm})$ is another weakly developed soil (7ACk horizon). It is a structureless grayish brown to dark grayish brown sandy clay loam. The common soft $\mathrm{CaCO}_{3}$ nodules and filaments are probably a postburial occurrence. Zone $10(153-170+\mathrm{cm})$ represents the parent material of the overlying soil. It is a $7 \mathrm{C}$ horizon consisting of a massive grayish brown loam.

Six buried soils are represented in Backhoe Trench 8. The pedogenic sequence and development of these soils are similar to those in Backhoe Trench 2. The strongest developed soil is the most recent one, which corresponds to the soil radiocarbon date of $80 \pm 60$ B.P. from Backhoe Trench 2. Earlier periods of soil development apparently were short lived, since the older soils in the profile are weakly developed.

Backhoe Trench 11 is located on the truncated windward side of the dune. This truncated surface gently dips eastward to the active windtidal flat. Backhoe Trench 11 is approximately $21.3 \mathrm{~m}$ long. Three localities along Backhoe Trench 11 - one near the western end (11a), one in the center (11b), and one near the eastern end (11c) - were described due to stratigraphic and geologic variations observed in the trench wall. Clay dune deposits and associated soils are present at each locality. The dune stratigraphy dips to the west; consequently, the basal zones present in the western locality are the more-surficial zones in the central and eastern localities. The dune stratigraphy of the three localities represents a continuous $2.35-\mathrm{m}$ vertical sequence of dune deposits and associated soils from the base of the dune on the underlying Beaumont Formation. Locality 11c, the easternmost locality, revealed a complex intersection of clay dune, wind-tidal flat, and late Pleistocene Beaumont Formation deposits (Figure 16). The base of the dune's windward face is represented in the Locality $11 \mathrm{c}$ profile, as well as tidal flat sediments that lap up onto the windward side and underlying deposits of the Beaumont Formation.
Locality 11 a consists of 11 zones ( 0 $138 \mathrm{~cm})$. Zone $1(0-10 \mathrm{~cm})$ is a grayish brown fine sandy loam consisting of fine thin $(<2 \mathrm{~mm})$ small ripples and planar laminations. This zone represents recent slopewash and alluvial fan sediments and is a $\mathrm{Cu}$ horizon. Zone $2(10-23 \mathrm{~cm})$ is a light brownish gray clay loam with moderate fine subangular blocky structure. Zone 2 is a C horizon. Zones 3 and $4(23-44 \mathrm{~cm})$ represent a buried soil. Zone 3 is a $9-\mathrm{cm}$-thick structureless dark gray clay loam and is classified as a $2 \mathrm{Abk}$ horizon. Common soft $\mathrm{CaCO}_{3}$ nodules throughout the zone are most likely a postburial phenomenon. Soil humates yielded a $\delta^{13} \mathrm{C}$-corrected radiocarbon assay of $1180 \pm 60$ B.P. Zone 4 is a $12-\mathrm{cm}$-thick light brownish gray clay loam with moderate fine subangular blocky structure and many soft $\mathrm{CaCO}_{3}$ nodules. Zone 4 is a $2 \mathrm{Bbk}$ horizon. Zones 5 and $6(44-78 \mathrm{~cm})$ are weakly developed buried soils. Zone 5 is a $17-\mathrm{cm}$-thick structureless grayish brown clay loam and is classified as a $3 \mathrm{ACk}$ horizon. Zone 6 is a 17-cm-thick structureless light brownish gray clay and is a 4ACk horizon. Both soils contain many soft $\mathrm{CaCO}_{3}$ nodules, which are probably postburial phenomena. Zones 7 and $8(78-116 \mathrm{~cm})$ represent the parent material of the overlying soil horizon. Zone 7 is a $28-\mathrm{cm}$-thick massive grayish brown clay, while Zone 8 is a $10-\mathrm{cm}$-thick massive light brownish gray clay. The zones are classified as $4 \mathrm{Ck}$ and $4 \mathrm{Ck} 2$ horizons, respectively. Zone $9(116-124 \mathrm{~cm})$ is another weakly developed buried soil (5ACk horizon) consisting of structureless dark gray clay loam. Zone $10(124-131 \mathrm{~cm})$ is a massive grayish brown sandy clay loam, representing the parent material of the overlying soil. Zone 10 is a $5 \mathrm{Ck}$ horizon. Zone $11(131-138+\mathrm{cm})$ is a weakly developed soil consisting of structureless dark gray sandy clay loam. Zone 11 is a $6 \mathrm{ACk}$ horizon.

Locality $11 \mathrm{~b}$ consists of nine zones $(0-122 \mathrm{~cm})$. Zone $1(0-10 \mathrm{~cm})$ is a grayish brown fine sandy clay loam consisting of thin $(<2 \mathrm{~mm})$ ripples and swales and a few thin muddy lenses. Zone 1 is recent slopewash and alluvial fan sediments and is classified as a $\mathrm{Cu}$ horizon. Zone $2(10-24 \mathrm{~cm})$ is a massive grayish brown sandy clay loam with many soft $\mathrm{CaCO}_{3}$ nodules. Zone 2 is classified as a Ck horizon. Zone $3(24-34 \mathrm{~cm})$ is a weakly developed buried soil. It consists of a structureless grayish brown sandy clay loam and is classified as a $2 \mathrm{ACk}$ horizon. Another weakly 


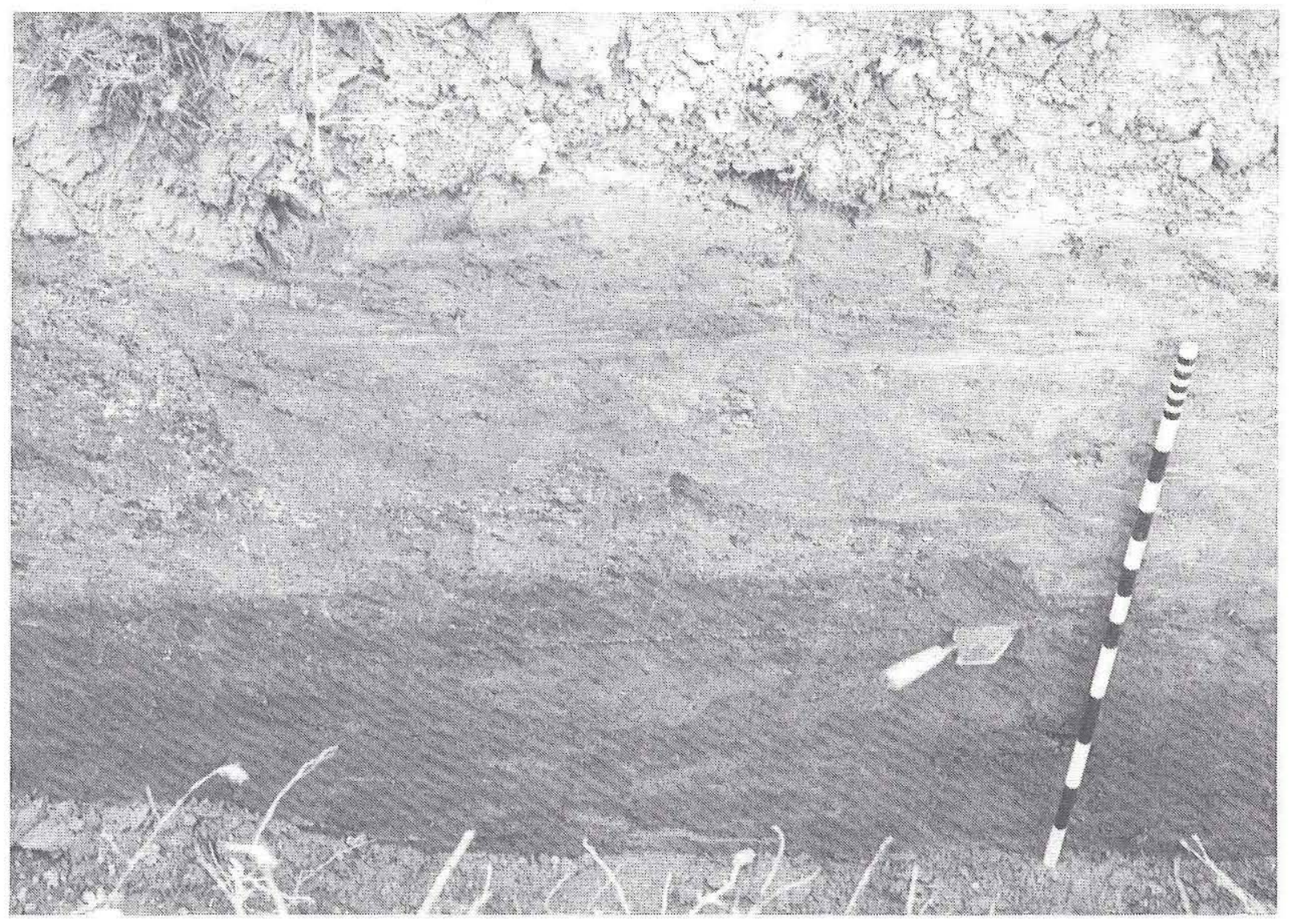

Figure 16. Backhoe Trench Locality 11c, 41WY50; note trowel at contact of the clay dune and Beaumont Formation.

developed soil (3ACk horizon) underlies Zone 3. Zone $4(34-54 \mathrm{~cm})$ is a structureless dark grayish brown sandy clay loam. A thin $(3 \mathrm{~cm})$ fine sandy lens is present at the bottom of the zone and may represent a storm washover fan. Zone 5 (54$68 \mathrm{~cm}$ ) represents the parent material of the overlying soil. It consists of a massive light brownish gray to grayish brown clay loam and is classified as a $3 \mathrm{Ck}$ horizon. Zone $6(68-83 \mathrm{~cm})$ represents another weakly developed soil, consisting of grayish brown clay loam with moderate fine subangular blocky structure. Zone 6 is a 4ACk horizon. Underlying Zone 6 is a more developed soil (5Ab horizon). Zone $7(83-90 \mathrm{~cm})$ is a dark gray clay loam with moderate fine subangular blocky structure. Zone $8(90-104 \mathrm{~cm})$ represents the parent material of the overlying soil. It is a massive grayish brown clay and is classified as a $5 \mathrm{C}$ horizon. Zone $9(104-122+\mathrm{cm})$ is a weakly developed soil consisting of a structureless dark gray clay loam. Zone 9 is a $6 \mathrm{AC}$ horizon.
Soil humates from the zone yielded a $\delta^{13} \mathrm{C}$ corrected radiocarbon assay of $2810 \pm 100$ B.P.

Locality $11 \mathrm{c}$ consists of seven zones (0$124 \mathrm{~cm})$. Zone $1(0-17 \mathrm{~cm})$ is a grayish brown fine sandy loam consisting of small ripples and swales and common thin $(<3 \mathrm{~mm})$ muddy lenses. Zone 1 is a $\mathrm{Cu}$ horizon representing recent slopewash, alluvial fan, and beach deposits. Zone $2(17-26 \mathrm{~cm})$ is a clay loam consisting of interbedded thin (1-10 $\mathrm{mm}$ ) grayish brown mud laminae and ripples and grayish brown to brown sand laminae and ripples. The sand percentages increase and the sands coarsen down-profile and basinward. Zone 2 is an inactive wind-tidal flat deposit and is classified as a $2 \mathrm{Cu}$ horizon. Zone 3 $(26-44 \mathrm{~cm})$ is a massive grayish brown clay with common to many soft $\mathrm{CaCO}_{3}$ nodules. These sediments fill an erosional cut near the base of the dune's windward face. Zone 3 is a $3 \mathrm{Ck}$ horizon. A bulk sediment sample yielded a $\delta^{13} \mathrm{C}$-corrected radiocarbon assay of $1260 \pm 80$ B.P. Underlying 
this fill is a soil (Zone 4) formed on a clay dune deposit. The soil (4Abk horizon) is an 11-cmthick dark grayish brown clay loam with weak fine subangular blocky structure. Soil humates from Zone 4 produced a $\delta^{13} \mathrm{C}$-corrected radiocarbon assay of $2320 \pm 90$ B.P. Zone $5(55-62 \mathrm{~cm})$ is a massive light brownish gray clay representing the parent material of the overlying soil. Zone 5 is classified as a $4 \mathrm{Ck}$ horizon. Zone $6(62-75 \mathrm{~cm})$ represents a basal dune deposit upon which a soil formed (5Abk horizon). The soil is a structureless dark grayish brown clay loam. Common soft $\mathrm{CaCO}_{3}$ nodules and incipient nodules are most likely postburial phenomena. Soil organics from the zone produced a $\delta^{13} \mathrm{C}$-corrected radiocarbon assay of $2690 \pm 60$ B.P. The base of the dune rests on the late Pleistocene Beaumont Formation (Zone 7). Zone $7(75-124+\mathrm{cm})$ is a brown moderate medium angular blocky structured clay loam. It is heavily turbated and contains a few $\mathrm{CaCO}_{3}$ nodules and common gypsum crystals.

Backhoe Trench Localities 11a, 11b, and 11c, along with Backhoe Trench 8 , provide a complete vertical sequence of the clay dune from the underlying Beaumont Formation to the modern surface (Figure 17). Dune aggradation apparently commenced at least by ca. 3000 B.P. based on radiocarbon assays on soil humates from basal zones. Accretion of the dune was relatively rapid, based on the presence of weakly developed soil profiles throughout the dune. Approximately 1416 soils are present in the entire preserved vertical sequence. Most of these consist only of a thin A or AC horizon. The strongest developed soil is one of the most recent, implying that aggradation of the clay dune has decreased dramatically in recent times. Decreased aggradation may be associated with the fact that the windward side of the dune has been truncated, creating an escarpment $0.5-$ $1.5 \mathrm{~m}$ high that greatly limits the amount of sediment transported by eolian processes up onto the preserved backside of the dune. Further discussions on the formation, sedimentology, and geochronology of the 41 WY 50 clay dune can be found in Chapter 6, along with their archeological implications.

\section{Summary and Conclusions}

The preservation and integrity of site $41 \mathrm{WY} 50$ were expected to be good. It was anticipated that the intact stratigraphy, recognizable features, datable materials, human remains, and shells reported by Day et al. (1981) also would be encountered during this phase of work. Intact, laterally consistent stratigraphy and recognizable

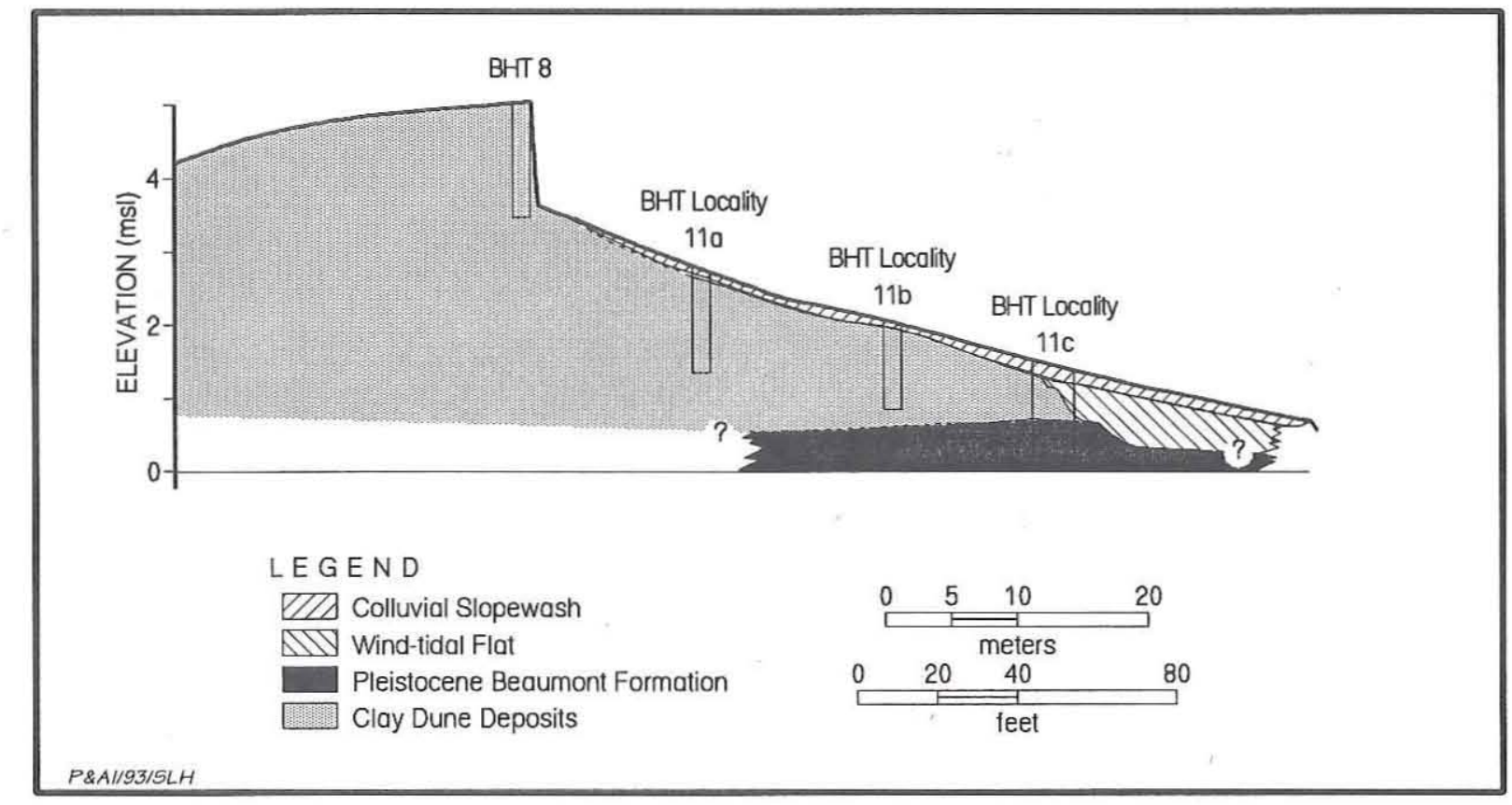

Figure 17. Sequence of deposits at $41 \mathrm{WY} 50$ as seen in the profiles of Backhoe Trench Localities 11a, 11b, and 11c and Backhoe Trench 8. 
features were encountered; however, definite cultural materials were not recovered.

A paucity of artifacts on archeological sites in the Lower Rio Grande Valley is not uncommon, but a complete absence of unquestionable cultural materials was not expected. The absence of temporally diagnostic artifacts makes it difficult to relate the occupation(s) of $41 \mathrm{WY} 50$ to others within the Lower Rio Grande Valley and adjacent regions. Furthermore, the lack of artifacts makes it extremely difficult to interpret how the site and the area were utilized. Site $41 \mathrm{WY} 50$ did yield a number of hearth features; however, their thin shallow nature, apparent lack of reuse, and lack of associated artifacts, macrobotanical remains, and faunal remains also make interpretation of feature and site utilization difficult. Several of these hearth features are at similar elevations and are probably associated with an occupation surface. It was expected that radiocarbon assays from these features would confirm this notion. However, due to the unfortunate loss of the radiocarbon samples, the ages of the features can only be estimated based on their provenience. The provenience of Feature 2 within a dated soil horizon (1200 \pm 70 B.P.) suggests that it and other features (particularly Features 1, 3, 5, 6, 9 and 10) at similar elevations are late Archaic in age. A late Archaic occupation of the site is also suggested by the radiocarbon-dated human remains previously recovered (Bousman et al. 1990:99). The late Archaic occupation of site 41WY50 was obviously short term and most likely does not represent repetitive use on a seasonal or yearly basis. A similar late Archaic occupation, consisting of few artifacts and a few small basin-shaped hearths, was documented on Loma Ochoa, a clay dune on the Rio Grande delta (Espey, Huston and Associates, Inc. 1990).

\section{SITE 41 WY 60}

\section{Site Description}

Site $41 \mathrm{WY} 60$ is located on the mainland coast of the Laguna Madre on the El Sauz Ranch (Figure 18). It lies $1.3 \mathrm{~km}$ east of the drainage ditch outfall and $5.9 \mathrm{~km}$ west of the southern end of Josephine Island. The elevation of the site is less than $5.5 \mathrm{~m}$ above mean sea level. The site is situated along the crest and windward face of the southern end of a large north-south-trending clay dune. The backside of the dune is covered by dense stands of thorny brush, including mesquite, trecul yucca, Texas ebony, and a variety of cacti. Open grassy areas are found along the crest and along the erosional face. Compared to site $41 \mathrm{WY} 50$, the clay dune at $41 \mathrm{WY} 60$ is relatively intact. The windward face is slightly eroded and gullied, but for the most part the windward side or slope is preserved right up to the active wind-tidal flat to the east. A burned clay lump and a marine shell fragment were observed on the surface. The site measures approximately $125 \mathrm{~m}$ north-south by 20-30 m east-west.

\section{Previous Investigations}

Site 41WY60 was recorded by Day et al. (1981) during a survey of the Hidalgo-Willacy Drainage Ditch outfall area. Cultural materials were observed eroding out of a 150-m-long exposed scarp face. Surface materials noted and collected included 1 modified primary flake, 4 ceramic sherds (possibly Rockport Ware), 6 marine pelecypods, 1 marine gastropod, 1 fish otolith, several terrestrial gastropods, and 31 unidentifiable bone fragments.

Two subsurface tests were placed in the southern and northern portions of the site on the crest of the dune. The southern probe measured $100 \times 100 \mathrm{~cm}$ and extended to $80 \mathrm{~cm}$ in depth. The profile revealed six natural strata consisting of brown clays and silts that became increasingly sandier down-profile. The other subsurface probe measured $100 \times 150 \mathrm{~cm}$ and involved cutting back a portion of the erosional face of the dune. It was $110 \mathrm{~cm}$ deep. The profile revealed seven natural strata, consisting mainly of light brown sands and silts, and one feature, a shallow basin-shaped hearth filled with charcoal and ashy sediment.

\section{Work Accomplished}

The current investigations included hand excavation of six $1-x-1-m$ test units; mechanical excavation of 11 backhoe trenches; collection of 56 sediment samples from backhoe trench profiles for radiocarbon assays, grain-size and soluble salts analyses, and pollen/phytolith analysis; profile cleaning; and site mapping.

The depths of the test units at 41WY60 


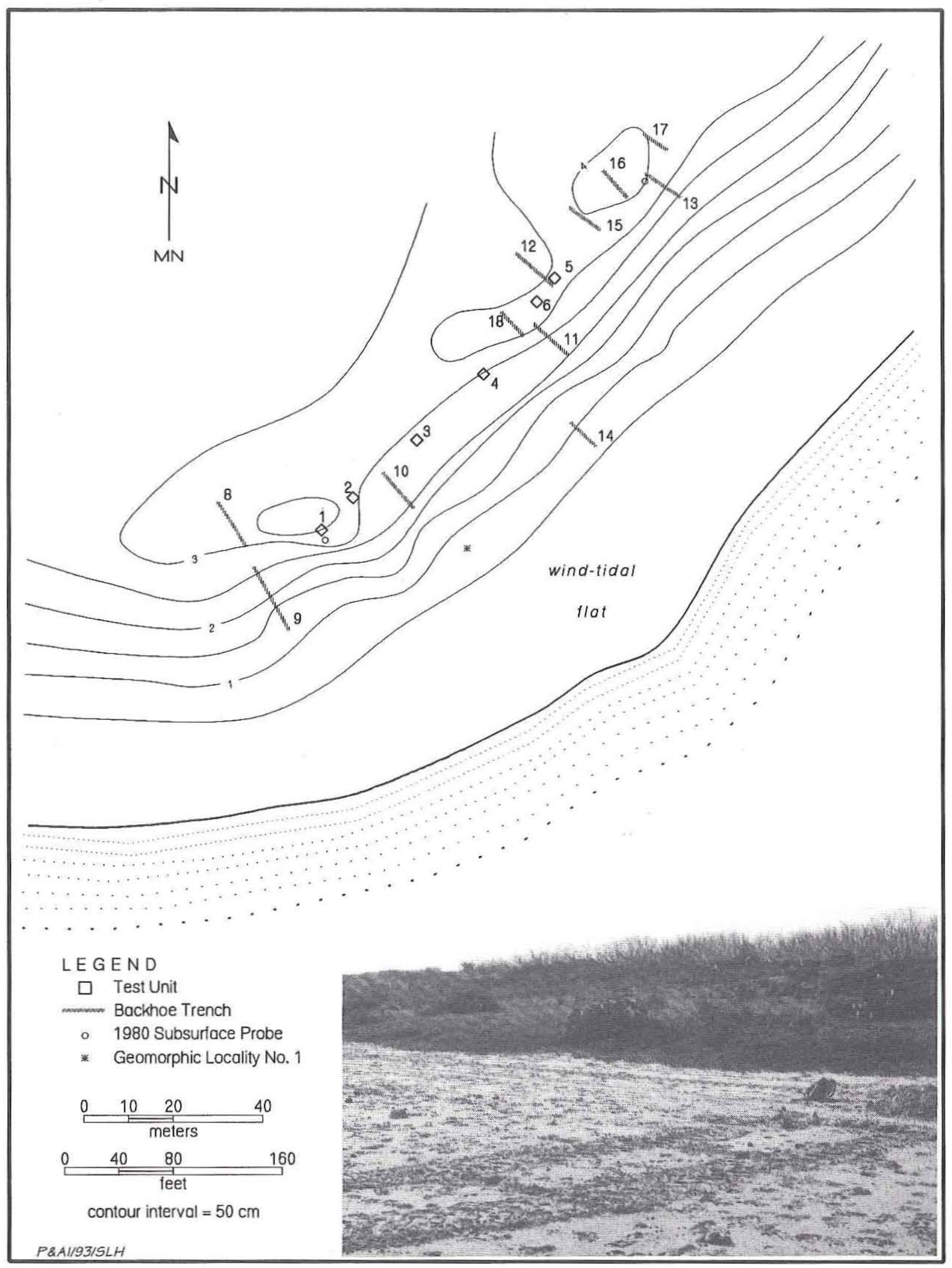

Figure 18. Site map and photograph, $41 \mathrm{WY} 60$; photograph is facing northwest toward the middle part of the site. 
ranged from $50 \mathrm{~cm}$ in Test Unit 6 to $150 \mathrm{~cm}$ in Test Unit 3. The lengths of the 11 backhoe trenches ranged from 6.8 to $16.0 \mathrm{~m}$, with the mean being $9.6 \mathrm{~m}$. The maximum depths of the trenches ranged from 0.9 to $2.1 \mathrm{~m}$, with the mean being $1.6 \mathrm{~m}$. Backhoe Trenches $9-11$ and 13 were excavated from the crest of the dune down the erosional windward face. Backhoe Trenches 8,12 , and 15-18 were excavated from the crest down the backside of the dune. Backhoe Trench 14 is a shallow trench excavated on the wind-tidal flat east of the dune. Six localities or profiles from six trenches (Backhoe Trenches 8-13) were described in detailed (see Appendix A). One wall along the long axis of each of four trenches (Backhoe Trenches 8-9 and 11-12) was completely profiled. The sediments and stratigraphy of the wind-tidal flat also were observed and documented from a 50-x-50-cm unit, known as Geomorphic Locality No. 1 (see Appendix A).

Of the 56 sediment samples collected for various analyses, two were submitted for radiocarbon dating. Because of the lack of features and artifacts, further analyses, including geomorphological and paleoenvironmental studies, were not pursued. The fill from Feature 1 was floated and charcoal obtained for radiocarbon dating. Unfortunately, this sample was lost en route to Beta Analytic, Inc.

A number of exposures and erosional faces along the crest of the dune were cut back and cleaned to detect cultural occupation zones and features. These profiles were no more than $40-$ $60 \mathrm{~cm}$ high and totaled approximately $56 \mathrm{~m}$ in length.

Site mapping was accomplished with a transit and metric stadia rod. No permanent datums were set on the site.

\section{Materials Recovered}

Few definite cultural materials were recovered from 41WY60. Lithics, ceramics, human remains, and modified shells were absent. Sixteen small bone fragments and 14 gravel- and pebblesized pieces of pumice were recovered, all from the upper levels (Levels 2-5) of the test units (Table 3). None of the faunal remains are associated with features, are burned, or appear to have cut marks (see Appendix B for species and element identification). The only definite cultural
TABLE 3

FAUNAL REMAINS AND PIECES OF PUMICE RECOVERED, 41WY60*

\begin{tabular}{|c|c|c|c|c|c|c|c|}
\hline $\begin{array}{c}\text { Level } \\
(\mathrm{cm})\end{array}$ & TU 1 & TU 2 & TU 3 & TU 4 & TU 5 & TU 6 \\
\hline $0-10$ & - & - & - & - & - & - \\
$10-20$ & - & $5 \mathrm{~F}$ & - & - & $1 \mathrm{~F}$ & - \\
$20-30$ & $1 \mathrm{~F}, 1 \mathrm{P}$ & - & $2 \mathrm{~F}$ & - & $4 \mathrm{~F}$ & $1 \mathrm{~F}$ \\
$30-40$ & - & - & - & - & $11 \mathrm{P}$ & - \\
$40-50$ & $1 \mathrm{~F}$ & - & - & - & $2 \mathrm{P}$ & $1 \mathrm{~F}$ \\
$50-60$ & - & - & - & - & - & - \\
$60-70$ & - & - & - & - & $\mathrm{x}$ & - \\
$70-80$ & - & - & - & - & $\mathrm{x}$ & - \\
$80-90$ & - & - & - & - & $\mathrm{x}$ & - \\
$90-100$ & - & - & - & - & $\mathrm{x}$ & $\mathrm{x}$ \\
$100-110$ & - & - & - & - & $\mathrm{x}$ & $\mathrm{x}$ \\
$110-120$ & $\mathrm{x}$ & - & - & - & $\mathrm{x}$ & $\mathrm{x}$ \\
$120-130$ & $\mathrm{x}$ & $\mathrm{x}$ & - & - & $\mathrm{x}$ & $\mathrm{x}$ \\
$130-140$ & $\mathrm{x}$ & $\mathrm{x}$ & - & - & $\mathrm{x}$ & $\mathrm{x}$ \\
$140-150$ & $\mathrm{x}$ & $\mathrm{x}$ & - & $\mathrm{x}$ & $\mathrm{x}$ & $\mathrm{x}$ \\
\hline
\end{tabular}

materials recovered are nine pieces of burned pumice associated with Feature 1. Like the materials recovered from $41 \mathrm{WY} 50$, most of the materials from 41 WY 60 cannot be attributed to human activities with any confidence.

\section{Feature}

One feature was documented at $41 \mathrm{WY} 60$ (Figure 19). It was exposed in the north wall at the east end of Backhoe Trench 12 and excavated by Test Unit 5 . Backhoe Trench 12 bisected the feature, but only a small portion of it remained intact in the south wall of the trench. Feature 1 is a shallow, basin-shaped hearth containing charcoal, ashy sediment, and nine pieces of burned pumice. A thin layer of white (10YR 8/2) eolian fine sand overlies the charcoal and ashy sediment. Burned clay lumps, commonly associated with small hearth features in the region, were absent. This absence is probably a testament to the intensity and duration of the fire. When first exposed in the trench wall, the feature measured $74 \mathrm{~cm}$ east-west; however, upon subsequent excavation, the feature was found to be $83 \mathrm{~cm}$ east-west by at least $124 \mathrm{~cm}$ north-south and 3-4 cm thick. The top of Feature 1 is $30-33 \mathrm{~cm}$ below the ground surface at 


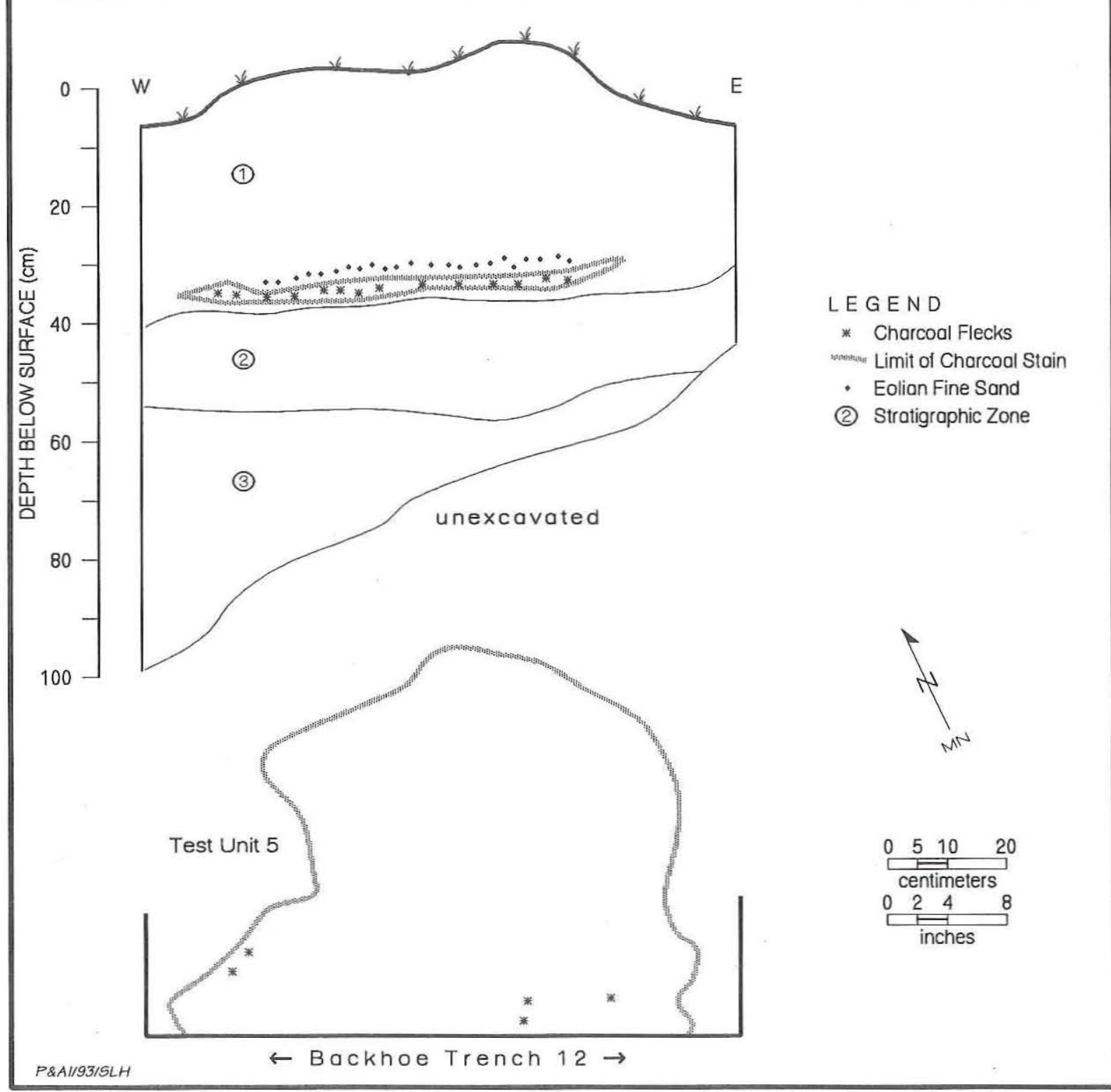

Figure 19. Profile of Feature 1 in north wall of Backhoe Trench 12 and plan of Feature 1 in Test Unit 5, 41WY60.

Test Unit 5. In plan view, it appears that the feature was probably oval shaped to amorphous.

The presence of burned pumice seems to be a very rare occurrence and poses an interesting question. The regional archeological literature does not provide any documentation of hearth features associated with pumice, but with an absence of rocks in the area, the presence of pumice in this feature suggests that it was used for stone boiling or baking pit construction. However, the use of pumice as a substitute for sandstone, limestone, or igneous rocks in stone boiling or hearth feature construction is not conclusive, especially when one considers that ceramic sherds were recovered from the site by Day et al. (1981) and that the archeological and ethnographic records suggest that stone boiling and ceramic use are mutually exclusive.

\section{Sediments and Stratigraphy}

The sediments and stratigraphy at $41 \mathrm{WY} 60$ 
were observed and documented from 6 of the 11 backhoe trenches and Geomorphic Locality No. 1. Two sediment samples were submitted for radiocarbon dating (Table 4). These observations and the results of the radiocarbon assays reveal that site 41WY60 sits on a Holocene eolian dune consisting mainly of sand and clay overlying the late Pleistocene Beaumont Formation. The clay dune contains many buried but weakly developed soils with thin mollic epipedons.

The modern surface soil is an Aridisol grading into a Ustoll (Mollisol) that belongs to the Lalinda (Turner 1982) soil series. Lalinda soils are classified as Ustollic Camborthids, Aridisols with cambic horizons and dry, thin mollic epipedons and/or gypsic or calcic horizons below the cambic horizon (Buol et al. 1980:253, 264). The epipedon or surface horizon is usually dark grayish brown to grayish brown sandy clay loam to clay loam. Subsurface horizons consist of grayish brown sandy clay loams to clays.

General descriptions and geomorphic interpretations of three of the six documented backhoe trenches and the one geomorphic locality are presented here (Figure 20). More-detailed descriptions of the sediments and stratigraphy of all six backhoe trenches and one geomorphic locality can be found in Appendix A.

Backhoe Trench 8 is located at the southern end of the site on the backside of the dune. It was excavated to a depth of $152 \mathrm{~cm}$ below the surface. Nine zones are identified and described from the west end of the trench.

Zone $1(0-35 \mathrm{~cm})$ is a grayish brown silty clay loam with moderate coarse angular blocky structure. A few very thin sandy laminae are present in the lower half of the zone. Zone 1 is an A horizon. Zone $2(35-45 \mathrm{~cm})$ is a zone of interbedded small ripples and planar laminations of brown sand and very dark grayish brown mud. The lower boundary of Zone 2 is very abrupt and smooth to wavy. Zone 2 represents a Cu horizon. Both Zones 1 and 2 represent recent deposition on the backside of the dune. A thin surface soil, represented by Zone 1, has developed on these deposits. These recent deposits buried a 9-cmthick dark gray silty clay loam soil (2Abk horizon) with moderate medium angular blocky structure represented by Zone 3. The presence of $\mathrm{CaCO}_{3}$ filaments are most likely postburial phenomena. Soil humates from Zone 3 yielded a $\delta^{13} \mathrm{C}$-corrected radiocarbon assay of $250 \pm 60$ B.P.

Zone $4(54-58 \mathrm{~cm})$ is a grayish brown clay loam with weak fine angular blocky structure. Humic materials are common. Zone 4 is classified as a $2 \mathrm{AC}$ horizon. Zones $5-6(58-81 \mathrm{~cm})$ consist of gray to dark gray and grayish brown clay loams to loams. These zones are $2 \mathrm{C}$ and $2 \mathrm{C} 2$ horizons, respectively, or parent materials of the overlying soil (Zones 3 and 4). Another buried soil (Zone 7) underlies Zone 6 . Zone $7(81-109 \mathrm{~cm})$ is a dark gray clay loam with weak medium subangular blocky structure. Zone 7 is a $3 \mathrm{Ab}$ horizon. Zone $8(109-144 \mathrm{~cm})$ is a massive grayish brown silty clay. It is a $3 \mathrm{C}$ horizon. Zone $9(144-152+\mathrm{cm})$ represents a buried soil (4Ab horizon), consisting of dark gray silty clay loam with weak fine subangular blocky structure.

The Backhoe Trench 8 profile reveals three buried soils representing intervals of surface stability. These stable intervals were probably short-lived given the weak development of the

\begin{tabular}{|l|l|l|l|l|}
\hline \multicolumn{5}{|c|}{ TABLE 4 } \\
\hline Lab No. & Provenience & $\begin{array}{l}\text { Uncorrected } \\
\text { Age B.P. }\end{array}$ & $\begin{array}{l}\text { Corrected Age } \\
\text { B.P.* }\end{array}$ & $\begin{array}{l}\text { Calibrated Age/Date (Intercepts } \\
\text { and One-Sigma Range)** }\end{array}$ \\
\hline Beta-61904 & BHT 8 & $100 \pm 60$ & $250 \pm 60(-16.0)$ & $\begin{array}{l}313(290) \text { 0 B.P. } \\
\text { A.D. 1637 (1660) 1954 }\end{array}$ \\
\hline Beta-61905 & BHT 12 & $60 \pm 70$ & $190 \pm 70(-17.2)$ & $\begin{array}{l}297(280,170,150,10,0) 0 \text { B.P. } \\
\text { A.D. 1653 (1670,1780, 1800, 1940, 1950) 1954 }\end{array}$ \\
\hline *Ages uncalibrated; $\delta^{13}$ C values in parentheses. \\
**Calibrations use 20-year atmospheric record of Stuiver and Pearson (1993).
\end{tabular}




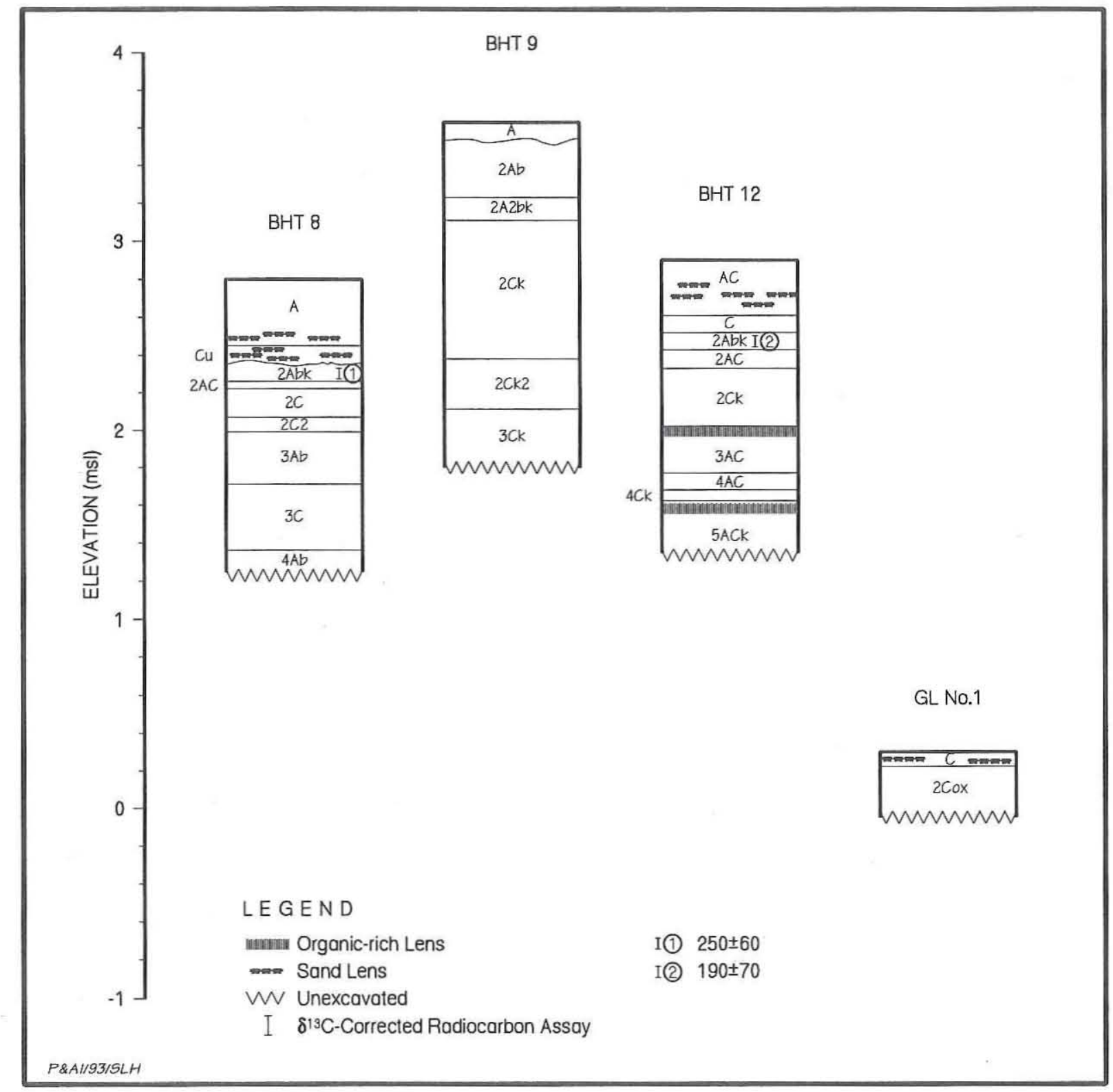

Figure 20. Profiles of Backhoe Trenches 8, 9, and 12 and Geomorphic Locality No. 1, 41WY60.

soils. This in turn suggests that the vertical accretion of the clay dune was relatively rapid, which is consistent with the age (200-300 years) of the first buried soil at $45 \mathrm{~cm}$ below the surface.

Backhoe Trench 12 is located at the northern end of the site on the backside of the dune and was excavated to a depth of $156 \mathrm{~cm}$ below the surface. Nine zones are identified and described from the west end of the trench.

Zone $1(0-30 \mathrm{~cm})$ represents the weakly developed modern surface soil (AC horizon). It is structureless grayish brown silty clay with a few thin lenticular planar-laminated sand bodies. Feature 1 is at the bottom of Zone 1, resting on top of Zone 2. Zone $2(30-38 \mathrm{~cm})$ is a dark gray massive silty clay loam. It is the parent material of the overlying soil. Zone 2 is classified as a $\mathrm{C}$ horizon. As in Backhoe Trench 8, Zones 1 and 2 of Backhoe Trench 12 are recent back-dune deposits that overlie an older soil. Zone $3(38-47 \mathrm{~cm})$ is a very dark gray clay loam soil (2Abk horizon) with moderate fine angular blocky structure. The common $\mathrm{CaCO}_{3}$ filaments throughout the zone are most likely a postburial occurrence. Soil humates 
from Zone 3 yielded a $\delta^{13} \mathrm{C}$-corrected radiocarbon assay of $190 \pm 70$ B.P. Zone 4 is a $10-\mathrm{cm}$-thick structureless dark grayish brown silty clay loam. It is classified as a $2 \mathrm{AC}$ horizon. Zone 5 (57$88 \mathrm{~cm}$ ) is a massive dark gray to grayish brown silty clay. It is a $2 \mathrm{Ck}$ horizon and represents the parent material of the overlying soil. Zones 6 and $7(88-122 \mathrm{~cm})$ are two weakly developed buried soils, 3AC and 4AC horizons, respectively. Zone $8(122-128 \mathrm{~cm})$ is a massive brown clay loam with common $\mathrm{CaCO}_{3}$ filaments and incipient nodules. It is classified as a 4Ck horizon. Zone 9 (128$156+\mathrm{cm}$ ) is another buried soil (5ACk horizon) consisting of a dark grayish brown to dark brown clay loam. Nodules and filaments of $\mathrm{CaCO}_{3}$ are common.

The Backhoe Trench 12 profile is very similar to the one documented in Backhoe Trench 8. It reveals four buried soils representing intervals of surface stability. These stable periods probably were short lived, given the weak development of the soils. This suggests that the vertical accretion of the clay dune was relatively rapid, which is supported by the age (200-300 years) of the first buried soil at $38 \mathrm{~cm}$ below the surface.

Backhoe Trench 9 was excavated on the erosional windward face of the dune. It was excavated to a depth of $182 \mathrm{~cm}$, and six zones were identified from the west end of the trench.

Zone $1(0-9 \mathrm{~cm})$ is grayish brown clay loam with weak fine subangular blocky structure. This is the A horizon of the modern surface soil. Zone 1 overlies a buried cumulic soil represented by Zones 2 and 3 . Zone $2(9-39 \mathrm{~cm})$ is grayish brown clay loam with strong medium subangular blocky structure. Zone 2 is a $2 \mathrm{Ab}$ horizon. Zone 3 is an 11-cm-thick grayish brown silty clay loam with moderate fine subangular structure. The few soft $\mathrm{CaCO}_{3}$ nodules are probably postburial phenomena. Zone 3 is classified as a $2 \mathrm{~A} 2 \mathrm{bk}$ horizon. Zone 4 $(50-124 \mathrm{~cm})$ is a massive grayish brown clay loam representing the parent material of the overlying soil. Soft nodules of $\mathrm{CaCO}_{3}$ are common, as are root casts formed of $\mathrm{CaCO}_{3}$. Zone 4 is a $2 \mathrm{Ck}$ horizon. Zone $5(124-151 \mathrm{~cm})$ is a massive pale brown silt loam with common soft $\mathrm{CaCO}_{3}$ nodules. Zone 5 is classifed as a 2Ck2 horizon. Zone 6 $(151-182+\mathrm{cm})$ is a massive yellowish brown silty clay loam with many soft $\mathrm{CaCO}_{3}$ nodules. Zone 6 is a $3 \mathrm{Ck}$ horizon. Although not chronometrically dated, the many $\mathrm{CaCO}_{3}$ nodules and the oxidized appearance of the sediments suggest that Zone 6 may be the Beaumont Formation. The top of the zone is approximately $2 \mathrm{~m}$ above the Beaumont Formation underlying the wind-tidal flat to the east (see Geomorphic Locality No. 1 below). This suggests that, if Zone 6 is a Beaumont Formation deposit, it is probably an ancient natural levee upon which clay dune formation is common. The north wall of Backhoe Trenches 10 and 11 revealed a similar deposit with oxidized sediments and an abundant amount of pedogenic carbonate nodules (Figure 21). These deposits are unlike the overlying dune deposits not only in color and degree of soil development but also in bed morphology. Although they are not chronometrically dated, they appear to be natural levee remnants of Pleistocene (Beaumont) age.

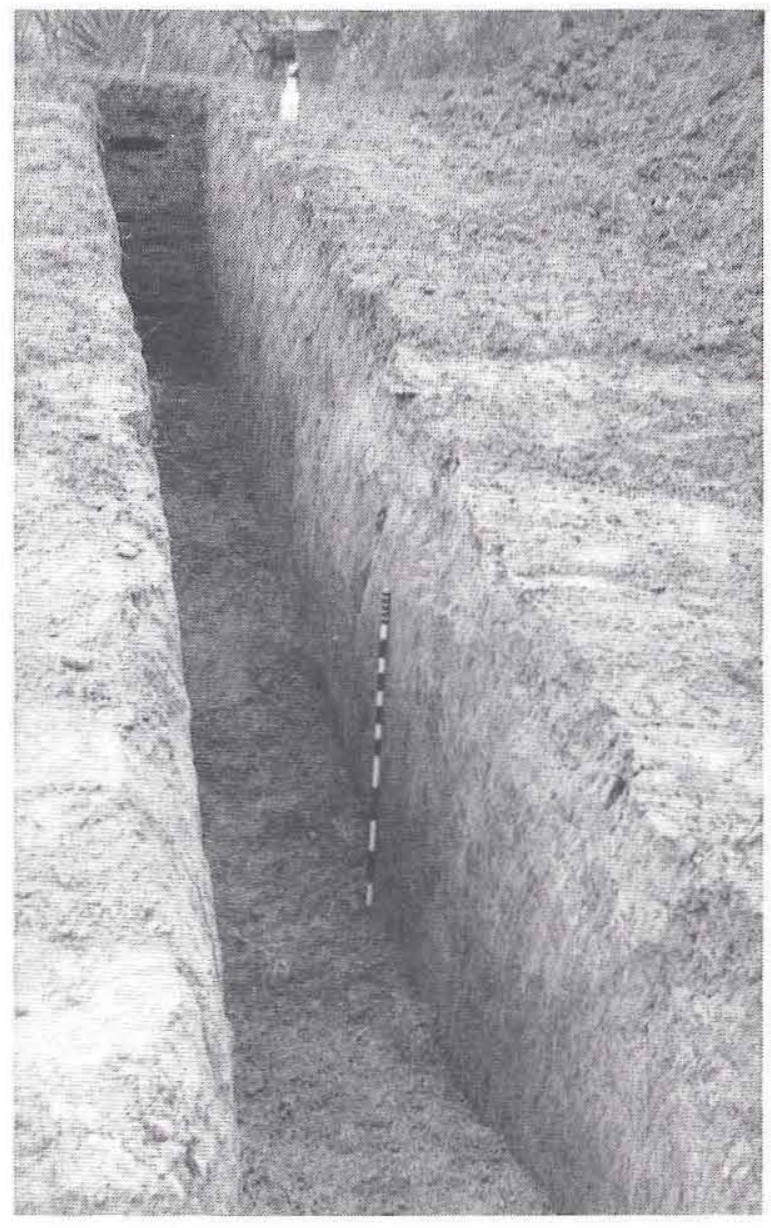

Figure 21. North wall of Backhoe Trench 10 showing Beaumont Formation natural levee (underlying darker zone), 41WY60.

Geomorphic Locality No. 1 is a $50-\mathrm{x}-50-\mathrm{cm}$ 
hand-dug unit located immediately east of the site on the wind-tidal flat. It was excavated to a depth of $32 \mathrm{~cm}$, and two zones were identified. Zone 1 $(0-7 \mathrm{~cm})$ represents recent wind-tidal flat deposits consisting of interbedded very pale brown to pale brown sand and grayish brown mud ripples. It overlies Zone $2(7-32+\mathrm{cm})$, a highly weathered strong coarse subangular blocky brown clay loam. Zone 2 represents the late Pleistocene Beaumont Formation.

The sediments and stratigraphy of site 41 WY60 reveal a clay dune that accreted rapidly and continues to do so. Pauses in dune growth or accretion are marked by buried soils. The weakly developed soils, represented by thin A and AC horizons, suggest that the intervals of stability were brief. The soils and stratigraphy are well preserved and intact on the leeward side of the dune and can be traced laterally throughout all the backhoe trenches excavated on the back side. The stratigraphy of the windward side reveals many truncated and disturbed zones due to continual cycles of erosion and deposition. Although the windward face is eroding through eolian processes, it appears that the clay dune itself is not moving laterally downwind but rather is accreting or building vertically.

Formation of the dune appears to be linked to a remnant of a late Pleistocene (Beaumont Formation) natural levee. This topographic rise served as a barrier and place of accumulation of eolian-transported sediments from the adjacent (upwind) wind-tidal flat. Evidence of an underlying late Pleistocene levee comes from basal deposits in several backhoe trenches. Although radiocarbon assays are not available from these deposits, the degree of pedogenic carbonate development, oxidized sediments, and bed morphology are indicative of a natural levee of extreme antiquity.

\section{Summary and Conclusions}

The preservation and integrity of site $41 \mathrm{WY} 60$ were expected to be good. As in the case of $41 \mathrm{WY} 50$, it was anticipated that the intact stratigraphy, features, datable materials, and ceramics reported by Day et al. (1981) also would be encountered during this phase of work. Intact, laterally consistent stratigraphy and a recognizable feature were encountered; however, definite cultural materials were not recovered.

A paucity of artifacts on archeological sites in the Lower Rio Grande Valley is not uncommon, but an absence of unquestionable cultural materials was not expected. The absence of temporally diagnostic artifacts makes it difficult to relate the occupation of 41 WY 60 to others within the Lower Rio Grande Valley and adjacent regions. Furthermore, the lack of artifacts makes it extremely difficult to interpret how the site and the area were utilized. Although 41WY60 did yield a hearth, its thin shallow nature, apparent lack of reuse, and lack of associated artifacts, macrobotanical remains, and faunal remains also make the interpretation of feature and site utilization difficult. The provenience of the feature above a radiocarbon-dated soil horizon $(190 \pm 70$ B.P. $)$ suggests that it dates to the early Historic period. The presence of possible Rockport ceramics also supports a Late Prehistoric/Historic occupation. This occupation was obviously short term and most likely does not represent repeated occupations on a seasonal or yearly basis. 


\section{RESULTS OF GEOMORPHOLOGICAL AND PALEOENVIRONMENTAL INVESTIGATIONS}

This chapter presents the results of the geomorphological and paleoenvironmental studies. First, the geomorphology of clay dunes in terms of their formation, sedimentology, and geochronology is discussed, and evidence of a Holocene high sea stand is presented. The second part presents the data and interpretations of the paleoenvironmental studies, which include stable carbon isotopic and pollen/phytolith analyses. The final parts are syntheses of the first two in terms of landscape stability, resource availability, and their geoarcheological implications. Most of the data presented below come from site 41WY50.

\section{GEOMORPHOLOGY}

\section{Clay Dune Formation and Sedimentology}

The genesis and formation of clay dunes have been documented extensively in the geologic literature (e.g., Huffman and Price 1949; Price 1958, 1963; Price and Kornicker 1961). Eolian dunes of clay are unique and peculiar in that fine particles such as clays usually are transported great distances from their source as suspended dust and deposited as massive sheets. These deposits are thickest near their source, and both grain size and bed thickness decrease downwind (Galloway and Hobday 1983:204; Waters 1992:186, 202). Generally, only sand or sand-sized particles accumulate as dunes or dune fields. Thus, the formation of clay dunes is the result of fine particles behaving like sand-sized particles. Coffey (1909) provides one of the earliest documentations of how this process works, crediting the unique climatic conditions of the south Texas coast and the eolian transport of sand-sized aggregates of clay from desiccated lagoon margins and bottoms.

Climatic and environmental conditions are important factors in the formation and geographical distribution of clay dunes (Huffman and Price 1949). Huffman and Price (1949:120) describe the distribution of clay dunes as limited to the leeward margins of saline wind-tidal flats and basins in arid to semiarid and dry subhumid zones with high potential evapotranspiration rates. Strong prevailing winds are also a key factor. All of these factors are prevalent on the south Texas coast, where clay dunes are present from Corpus Christi Bay to the Rio Grande delta and south along the Gulf coast of Tamaulipas, Mexico.

The predominant sediment source for the clay dunes along the south Texas coast is wind-tidal flats. Extensive flats are present along the western margin of the Laguna Madre, particularly along the margins of the Rio Grande delta and the area between the Cayo Atascosa and Fourmile Slough. These wind-tidal flat areas are associated with the Gavilan and the Hawk Island accretionary claysand dunes, respectively (Brown et al. 1980:88). Brown et al. (1980:75) identify four types of windtidal flats along the south Texas coast: (1) firm sand and mud flats; (2) soft mud and sand with extensive algal mats that are frequently wet; (3) sand and mud flats that are alternately emergent and submergent; and (4) firm gypsiferous mud and sand with algal-bound mud. The last two types are found in the project area. Granulometric data from wind-tidal flat deposits at 41WY50 (Backhoe Trench Locality 11d) reveal a bimodal clast size distribution. The modes are very fine to fine sands and clays finer than 9 phi, while silt-sized particles are rare (Figure 22). Log probability 

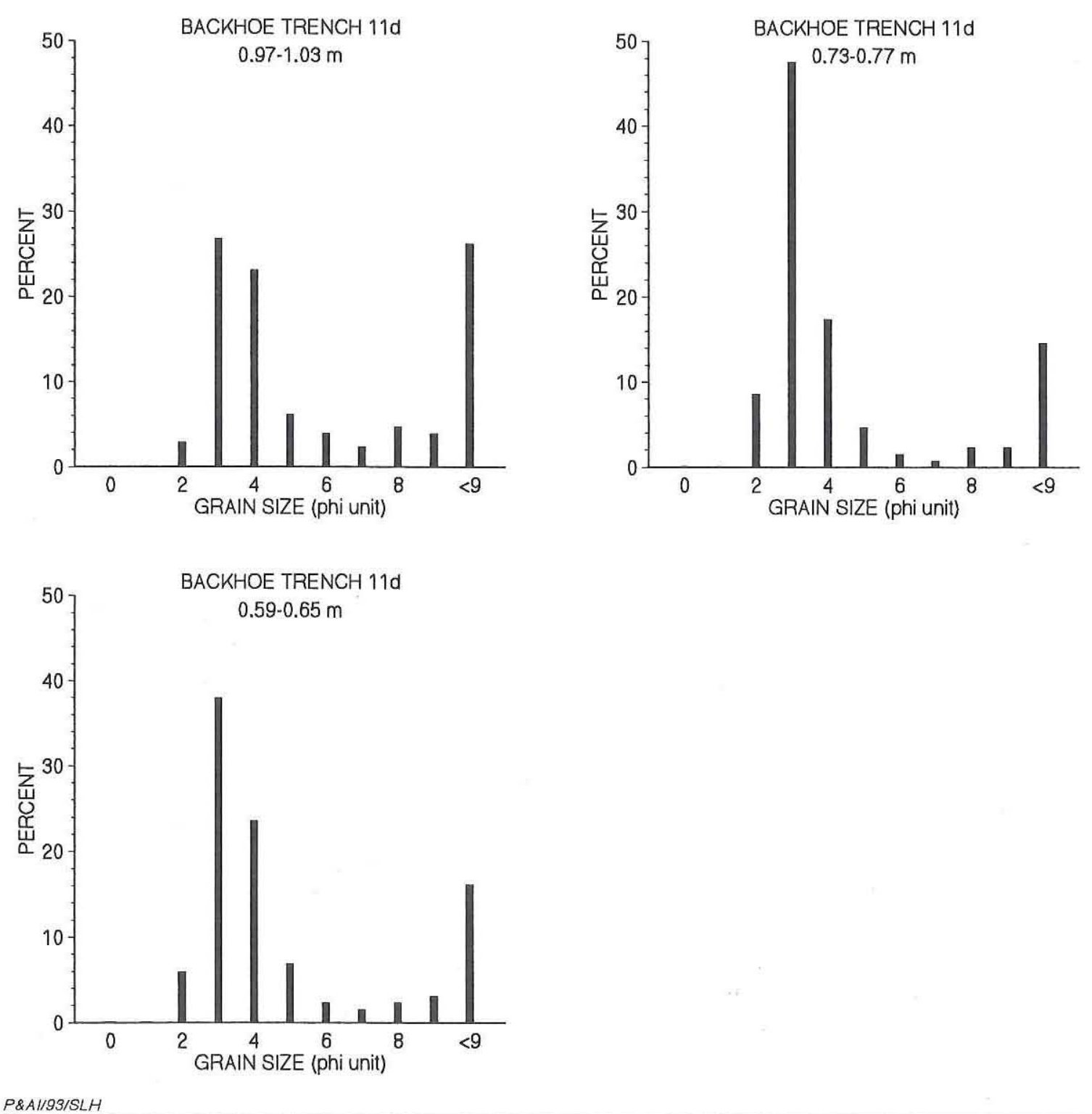

Figure 22. Grain-size distributions of wind-tidal flat sediment samples, 41 WY50.

plots of the cumulative weight percentages of the wind-tidal flat sediment samples differentiate traction, saltation, and suspension populations (Figure 23). The saltation populations represent the dominant mode of transport and are very well sorted, while the traction populations are very small and truncated at 1 phi. Clear truncations between the saltation and suspension populations do not exist, representing a mixing of saltation and suspension populations at the 3- and 4-phi intervals. This is probably the result of decreasing tidal velocities and the cyclical flooding and retreating nature of the wind tides on the flat.

The flooding of wind-tidal flats is erratic because astronomical tides are negligible along most parts of the south Texas coast (Brown et al. 1980; Fisk 1959). Submergence is caused by wind-driven waters or drops in barometric pressure (White et al. 1989). Flooding exposes the sediments, particularly the clays, to evaporite salts, which along with algal fibers bind clays into sandsized pellets or aggregates upon retreat of the 


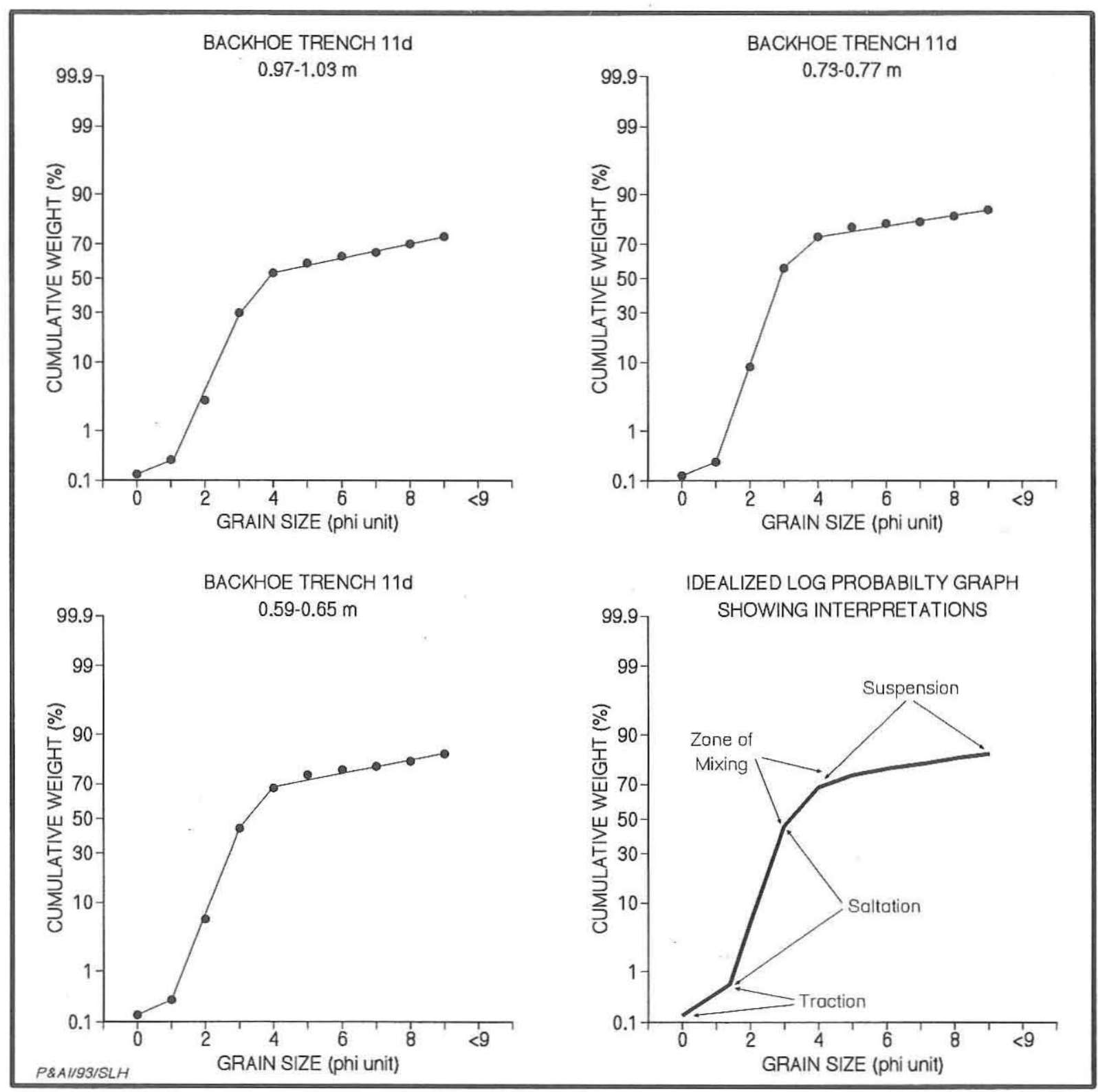

Figure 23. Log probability graphs for wind-tidal flat sediment samples, 41WY50.

water and drying. The drying out and disintegration of the wind-tidal flat surface or crust and formation of clay aggregates involves various processes (Price 1963:767), including the crystallization or growth of evaporite salts penetrating the upper layer of crust, the development of a microrelief pattern of blisters on the surface which break down with further drying, and the curling up of the thin fragile surface of sun-cracked polygons which are broken down mechanically by the wind (Figure 24). The clay pellets are transported by the wind to the leeward margins of the wind-tidal flat and accumulate wherever obstructions, such as low brushy vegetation or areas of local topographical relief (e.g., natural leeves), occur.

The presence of evaporite salts in the clay plays a very important role in clay dune formation by controlling the moisture-holding and moisturereleasing ability or "hygroscopicity" of the saline clay pellets (Price 1963:766). The gain and loss of moisture can occur with changes in atmospheric temperature and humidity, causing the clay to 


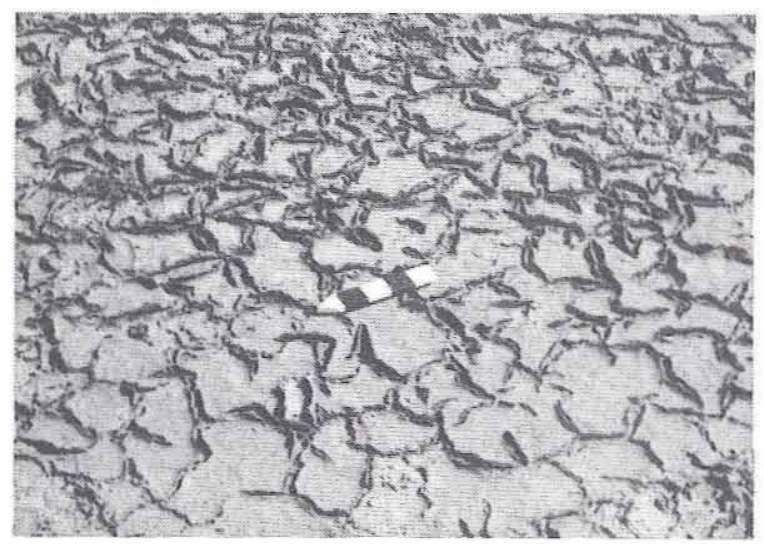

Figure 24. Desiccation cracks and polygons on windtidal flat at 41WY50.

expand or contract. Although the salts are formed by the desiccation of the wind-tidal flat surface, Price (1963) found that the salts also enable the clay pellets to retain enough moisture in their core to keep their form for the period of time it takes to transport them from the flat to the dune (Huffman and Price 1949:124). Upon deposition, the clay pellets may absorb moisture from atmospheric humidity through the incorporated evaporite salts or when the clay is wetted by rain. Once sufficient moisture is absorbed, the pellets regain some of their former plasticity, flocculate, and become fixed in the dune, stabilizing the dune and preventing lateral or downwind migration (Price 1963:766) (Figure 25). The internal bedding structures of clay dunes also suggest that migration does not occur (Price 1963:773). The formation of clay dunes, therefore, is the result of a delicate balance between drying conditions that form saline clay aggregates and the ability of the aggregates to maintain enough moisture to keep their form, for which the evaporite salts play a major role (Price 1963:766). It should be noted that active clay dunes have not been documented from nonsaline flats undergoing deflation, and there seems to be no way in which nonsaline clay will produce a large percentage of sand-sized aggregates for eolian transport and dune formation (Price 1963: 767, 772).

The sedimentology of clay dunes is difficult to interpret because of the unique processes behind their formation. Granulometric data from the clay dune at site $41 \mathrm{WY} 50$ reveal that the deposits are poorly sorted (see Appendix B), which is not surprising considering the nature of their formation.

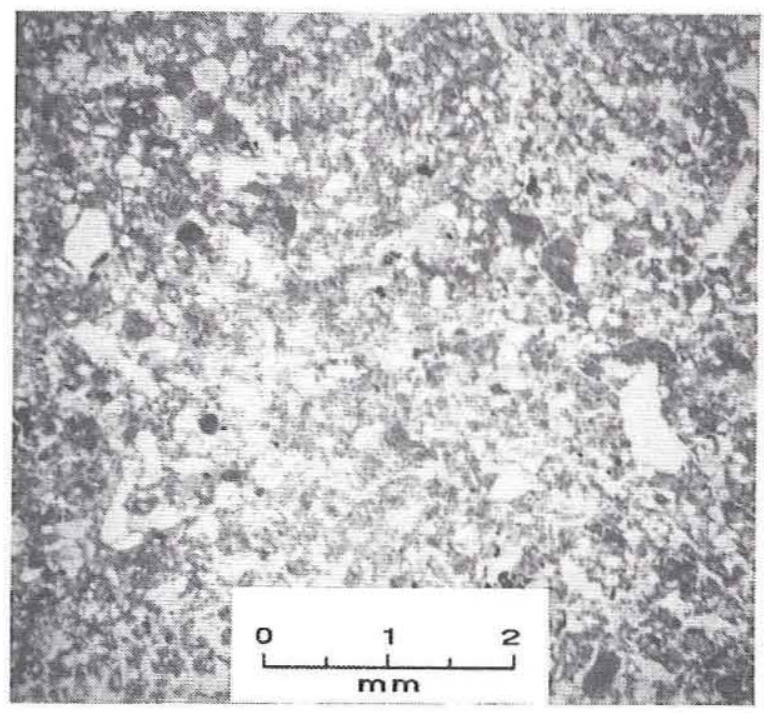

Figure 25. Clay pellets (dark circles) in thin section of sediment sample from 41WY50.

Sediment samples throughout the dune disclose a clear bimodal distribution of very fine to fine sands and clays finer than 9 phi (Figure 26). These distributions are similar to those of the wind-tidal flat samples. Silt-sized particles are uncommon, as they are in the deposits of the wind-tidal flat. Such distributions make sedimentological interpretations difficult. However, since the clays were deposited as sand-sized aggregates, a better understanding of clay dune sedimentology may be obtained from an examination of the sand populations alone, as separated by the sieve analysis (in which clay aggregates are broken down and thus excluded).

The sand populations consist of subangular and angular quartz sand that is moderately well sorted (Table 5). The sand samples have mean grain sizes ranging from 2.79 to 3.12 phi and are asymmetrically skewed with a dominant mode located at the 3- and 4-phi intervals. This suggests that the clay aggregates were deposited as fine and very fine sand-sized particles.

Log probability plots of cumulative weight percentages of the clay dune sediment samples (excluding clays in the 9-phi and $<9$-phi fractions) were graphed to infer modes of sediment transport and depositional processes. Most of the graphs produced are nonsensical, and this may be the result of more than one depositional process and/or the gross intervals (i.e., 1 phi) of the sediment data. Folk (1980:31) recommends 0.25-phi 

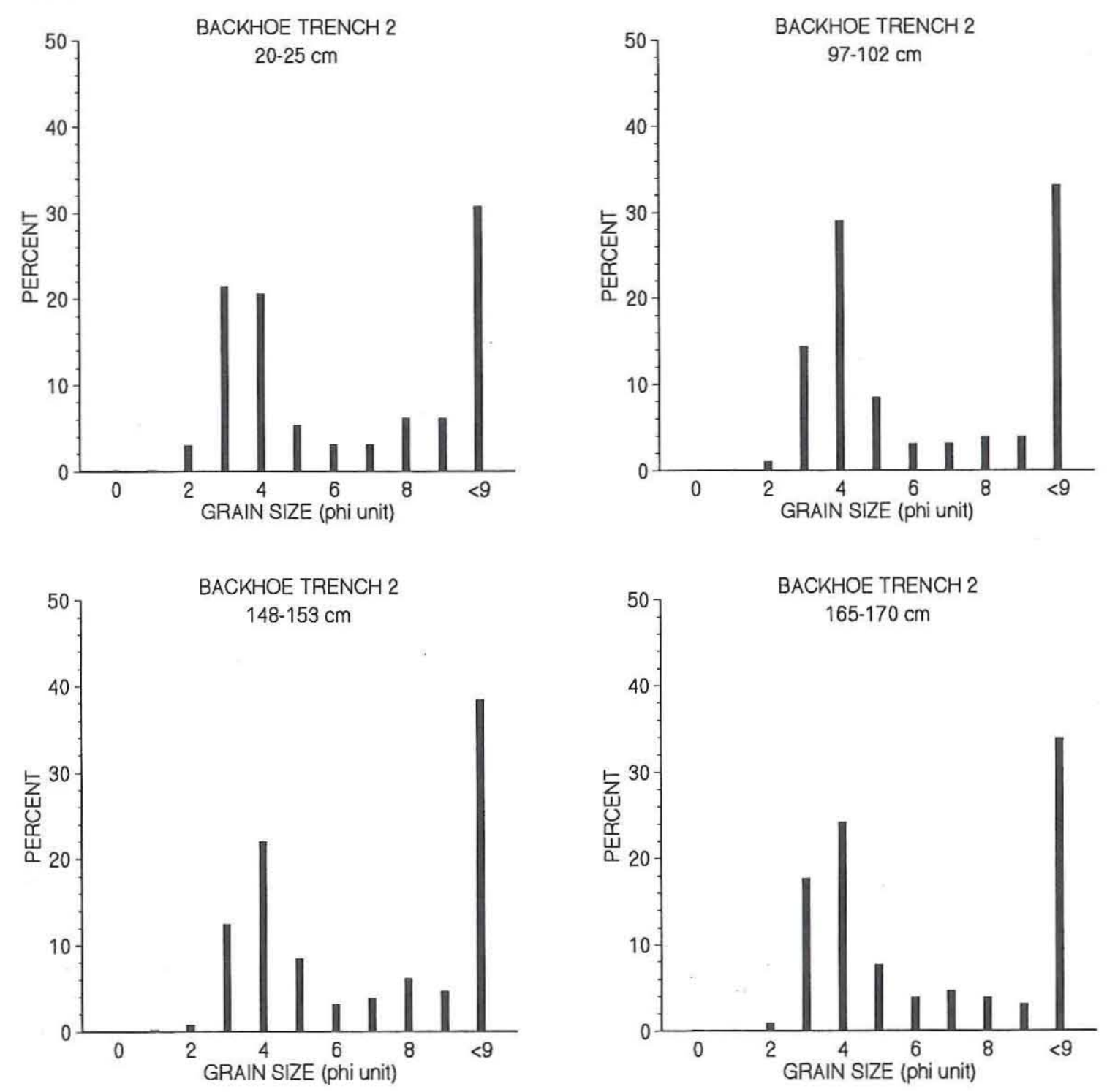

P\&AI/93/SLH

Figure 26. Grain-size distributions of selected clay dune sediment samples, 41WY50.

intervals for accurate work; however, it is speculated that the incomprehensible graphs are more the result of multiple depositional processes rather than an inappropriate analysis interval since useful data were obtained from the wind-tidal flat samples at 1 -phi intervals. The few clay dune sample graphs that are useful reveal three to four populations. Normally, eolian deposits have three distinct populations with two clear truncation points and are characterized by a very small moderately sorted traction population, a dominant
(97-99\% of the sample) very well-sorted saltation population, and a very small suspension population (Visher 1969). Some of the samples from 41 WY50 have two small traction populations, suggesting a possible mix of eolian and stormsurge deposits, the latter being represented by the coarser population. Truncation points at 2 phi consistently separate the eolian traction populations from the eolian saltation populations throughout the samples examined. The saltation populations represent the dominant mode of 
TABLE 5

SAND PERCENTAGES OF CLAY DUNE SAMPLES, 41 WY50

\begin{tabular}{|c|c|c|c|c|c|c|c|}
\hline Provenience & $0 \mathrm{phi}$ & $1 \mathrm{phi}$ & $2 \mathrm{phi}$ & 3 phi & $4 \mathrm{phi}$ & Mean Sand Size & Standard Deviation \\
\hline \multicolumn{8}{|c|}{ Backhoe Trench 2} \\
\hline $0-4 \mathrm{~cm}$ & 0.24 & 0.24 & 2.97 & 49.76 & 46.78 & 2.93 & 0.59 \\
\hline $20-25 \mathrm{~cm}$ & 0.35 & 0.35 & 6.65 & 47.30 & 45.35 & 2.87 & 0.66 \\
\hline $46-51 \mathrm{~cm}$ & 0.00 & 0.42 & 4.25 & 46.72 & 48.61 & 2.94 & 0.60 \\
\hline $82-87 \mathrm{~cm}$ & 0.00 & 0.36 & 3.18 & 38.51 & 57.96 & 3.04 & 0.59 \\
\hline $97-102 \mathrm{~cm}$ & 0.00 & 0.36 & 2.39 & 32.28 & 64.97 & 3.12 & 0.59 \\
\hline $110-116 \mathrm{~cm}$ & 0.00 & 0.39 & 6.06 & 49.37 & 44.17 & 2.87 & 0.62 \\
\hline $133-138 \mathrm{~cm}$ & 0.00 & 0.33 & 3.61 & 41.89 & 54.17 & 3.00 & 0.59 \\
\hline $148-153 \mathrm{~cm}$ & 0.00 & 0.49 & 2.16 & 35.15 & 62.20 & 3.09 & 0.58 \\
\hline $165-170 \mathrm{~cm}$ & 0.36 & 0.36 & 2.02 & 41.16 & 56.09 & 3.02 & 0.60 \\
\hline \multicolumn{8}{|c|}{ Backhoe Trench 11a } \\
\hline $17-23 \mathrm{~cm}$ & 0.33 & 0.33 & 3.34 & 49.67 & 46.33 & 2.91 & 0.61 \\
\hline $29-33 \mathrm{~cm}$ & 0.39 & 0.39 & 3.88 & 43.14 & 52.20 & 2.96 & 0.63 \\
\hline $38-43 \mathrm{~cm}$ & 0.38 & 0.38 & 3.08 & 47.69 & 48.46 & 2.93 & 0.61 \\
\hline $56-60 \mathrm{~cm}$ & 0.44 & 0.44 & 5.86 & 53.71 & 39.55 & 2.81 & 0.65 \\
\hline $73-78 \mathrm{~cm}$ & 0.52 & 0.52 & 6.98 & 53.55 & 38.42 & 2.79 & 0.68 \\
\hline $89-93 \mathrm{~cm}$ & 0.00 & 0.40 & 4.43 & 49.58 & 45.60 & 2.90 & 0.59 \\
\hline $108-113 \mathrm{~cm}$ & 0.40 & 0.44 & 1.33 & 33.20 & 64.63 & 3.11 & 0.61 \\
\hline \multicolumn{8}{|c|}{ Backhoe Trench 11b } \\
\hline $18-21 \mathrm{~cm}$ & 0.00 & 0.28 & 2.76 & 47.88 & 49.08 & 2.96 & 0.57 \\
\hline $26-30 \mathrm{~cm}$ & 0.25 & 0.25 & 6.22 & 48.62 & 44.66 & 2.87 & 0.64 \\
\hline $43-48 \mathrm{~cm}$ & 0.28 & 0.28 & 5.22 & 51.57 & 42.66 & 2.86 & 0.62 \\
\hline $57-62 \mathrm{~cm}$ & 0.39 & 0.43 & 4.31 & 38.81 & 56.06 & 3.00 & 0.64 \\
\hline $73-78 \mathrm{~cm}$ & 0.40 & 0.80 & 6.77 & 43.43 & 48.61 & 2.89 & 0.69 \\
\hline \multicolumn{8}{|c|}{ Backhoe Trench 11c } \\
\hline $30-35 \mathrm{~cm}$ & 1.14 & 1.71 & 5.71 & 37.71 & 53.71 & 2.91 & 0.77 \\
\hline $50-54 \mathrm{~cm}$ & 0.38 & 0.85 & 5.09 & 47.90 & 45.78 & 2.88 & 0.66 \\
\hline $59-63 \mathrm{~cm}$ & 0.33 & 0.37 & 4.46 & 50.58 & 44.25 & 2.88 & 0.62 \\
\hline $68-72 \mathrm{~cm}$ & 1.17 & 1.17 & 5.06 & 46.30 & 46.30 & 2.85 & 0.74 \\
\hline
\end{tabular}

transport but consist of much smaller portions of the samples than noted by Visher (1969:1104). Because the clay-sized particles are excluded from these plottings, it is assumed that large portions of the saltation populations are represented by fine to very fine sand-sized aggregates of clays. If the clays ( 9 and $<9$ phi) are grouped with the very fine ( 4 phi) and fine ( 3 phi) sands based on the relative sizes of the 3- and 4-phi intervals, more-typical distributions can be graphed (Figure 27). Rarely are the saltation populations truncated in the samples examined, but when they are truncated, it is consistently at the 4-phi interval. Instead, a zone of mixing, represented at 3 and $4 \mathrm{phi}$, is prevalent. This maybe the result of varying wind velocities or a mixing of eolian and storm-surge sediments. The suspension populations are represented by small silt fractions and tend to reveal severe mixing probably of eolian fines and slackwater deposits from tropical storm inundation.

The sedimentological analysis of the clay dune at 41 WY50 reveals a mix of sand and clay particles. Eolian deposition is the predominant process, with saltation representing the dominant mode of transport. The saltation population consists primarily of very fine to fine quartz sands 


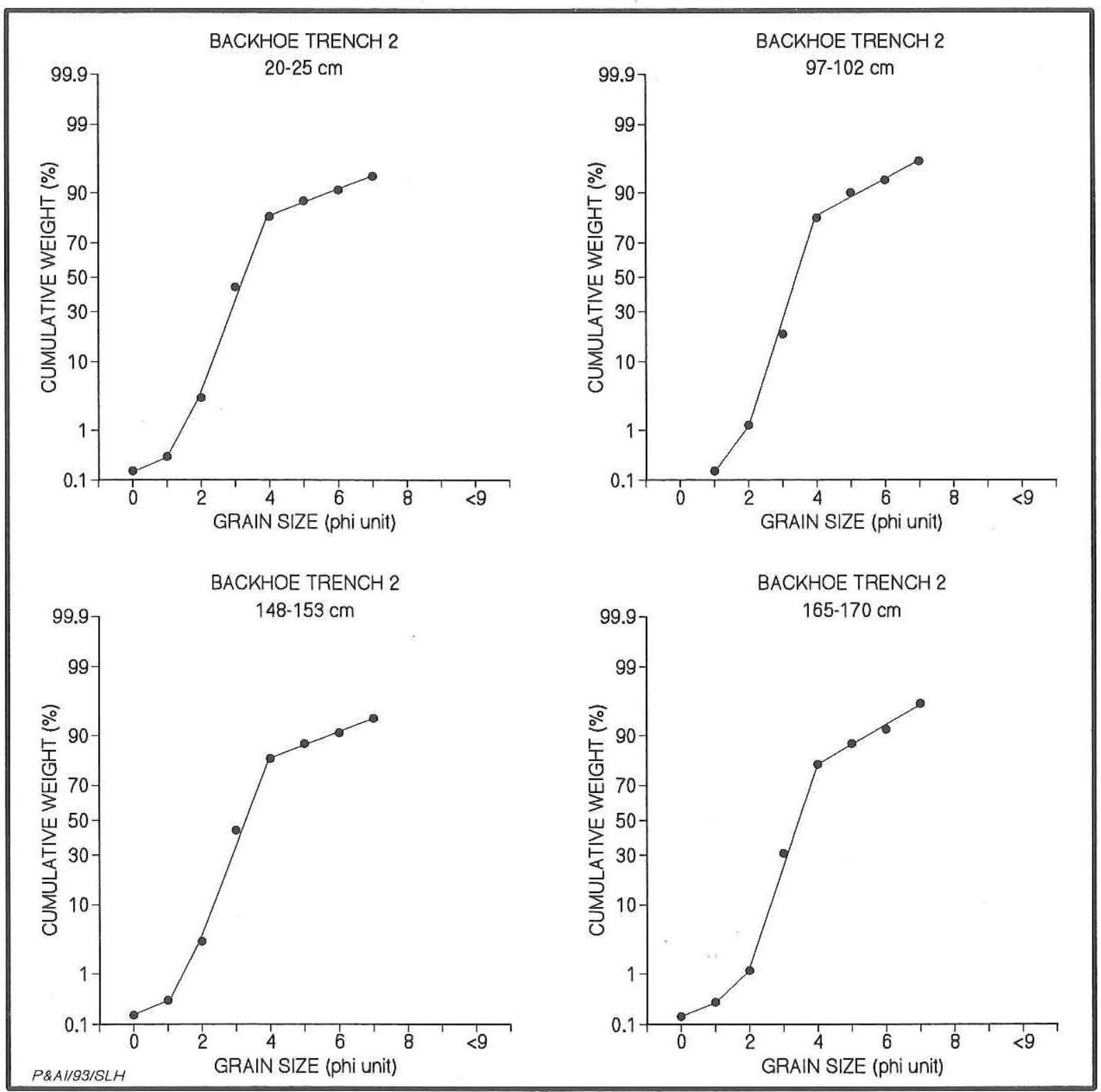

Figure 27. Log probability graphs for selected clay dune sediment samples from 41WY50; the clays have been added proportionally to the 3 - and 4 -phi intervals.

and very fine to fine sand-sized aggregates of clay. Sediments deposited by storm surges represent a secondary component of the clay dune.

The clay dunes tend to be steepest on the windward side and more gently sloping on the leeward side, which merges with the Beaumont surface (Huffman and Price 1949:124). Since clay dunes do not migrate downwind, dune growth occurs by vertical accretion and progradation toward its sediment source. Slip faces, therefore, are absent in clay dunes except under rare conditions of extreme drought and rapid accumulation (Price 1963:773). Storm surges and rains often leave the windward face intensively weathered and eroded, while the leeward slope is generally less eroded due partly to vegetation. Salt-tolerant vegetation is able to gain a foothold on the dune only after a period of leaching. However, on actively accreting dunes, the vegetation is periodically killed when new deposits of saline clays accumulate on the surface (Price 1963: 774). On relict dunes such as the backside of 
41WY50, the soil becomes permanently less saline and able to support the common vegetation of mesquite, prickly pear, trecul yucca, saltweed, and salt-resistant grasses, further stabilizing the dune (Huffman and Price 1949:127; Price 1963:774776).

The internal structure of a clay dune usually consists of leeward-dipping beds of sediment marked by intervals of stability or buried soils. These structures are particularly well preserved in the lee side of the dune. Rarely preserved 1-3-cm-thick graded beds were revealed through micromorphological analysis of bulk sediment thin sections. Other internal structures include thin sand lenses.

\section{Geochronology}

Although the windward face of the 41WY50 clay dune is truncated, a complete vertical sequence of deposits from the underlying Beaumont Formation to the modern surface can be tied together from various profiles (Figure 28). This vertical sequence, along with seven radiocarbon assays (see Table 2 in Chapter 4), provides a complete geochronological history of the dune.

Dune aggradation apparently commenced by ca. 3000 B.P., based on radiocarbon assays on soil humates from basal zones. The growth rates of the dune are estimated to have ranged from 4 to $17 \mathrm{~cm}$ per century; this is much slower than the $15-31 \mathrm{~cm}$ per century speculated for clay dune growth by Price and Kornicker (1961:248) but is comparable to the rates of 9.5 to $14.5 \mathrm{~cm}$ per century that Espey, Huston and Associates, Inc. (1990:220) documented for Loma Ochoa. Initially, deposition was slow, around $5 \mathrm{~cm} / 100$ years during the first 500 years of dune development. However, in an ensuing span of approximately $1,200-1,500$ years, depositional rates increased to $12-17 \mathrm{~cm}$ per century, only to decrease again to $4 \mathrm{~cm}$ per century in the last 1,100 years.

These varying rates of sedimentation are supported by the approximately $14-16$ soils that are preserved in the dune. Most of these soils are weakly developed and consist only of thin A or AC horizons, suggesting that dune accretion was relatively rapid. The strongest developed soil in the sequence is one of the most recent (e.g., Zones 2 and 3 of Backhoe Trenches 2, 5, 7, and 8), supporting the notion that aggradation of the clay dune has decreased dramatically in the last 1,100 years.

Decreased aggradation may be associated with truncation of the windward side of the dune, which has created a $0.5-1.5-\mathrm{m}-\mathrm{high}$ escarpment that greatly limits the amount of sand and clay aggregates transported by eolian processes up onto the preserved backside of the dune (Figure 29). This escarpment most likely was created by highly erosive marine waves related to tropical storms. The modern truncated surface of the dune is littered with large amounts of drift debris, indicating that storm surges regularly inundate at least a portion of the dune. The truncated surface also consists of slopewash and alluvial fan sediments that bury the actual truncated dune deposits. Basinward, the surface consists of beach sands deposited during intense storms.

When the erosion of the windward side of the dune occurred is unclear. A maximum date of 1420-1197 B.P. (one-sigma calibrated range of $1415 \pm 140$ B.P.) for truncation is suggested by the human burial that was eroding out of the wave-cut escarpment. This concurs with the formation of an erosional gully on the windward face of the dune (Backhoe Trench Locality 11c, Zone 3), based on the later radiocarbon-dated gully fill of ca. 1170 B.P. Both of these dates coincide with the decreased rate of sedimentation occurring in the last 1,100 years, which presumably was brought on by the formation of the escarpment. These ages also seemingly concur with the calibrated date (ca. 1070 B.P.) of the uppermost buried soil at Backhoe Trench Locality 11a. However, this date probably is too young based on the sample's provenience, and these deposits should date between ca. 10802880 B.P. (the calibrated dates of the Backhoe Trench 8 and Backhoe Trench Locality 11b radiocarbon assays). Because of the close proximity of the Backhoe Trench Locality 11a sample to the overlying reworked colluvial surface, contamination through the translocation of morerecent organics is possible.

Interestingly, much earlier storm or floodwater inundation of the clay dune prior to 1100 B.P. is represented by many thin sand lenses (e.g., Zone 6 of Backhoe Trenches 7 and 9 and Zone 7 of Backhoe Trenches 2 and 6). This interval of inundation appears to have been on a much larger scale, for the sand lenses are present throughout the backside of the dune. Based on 


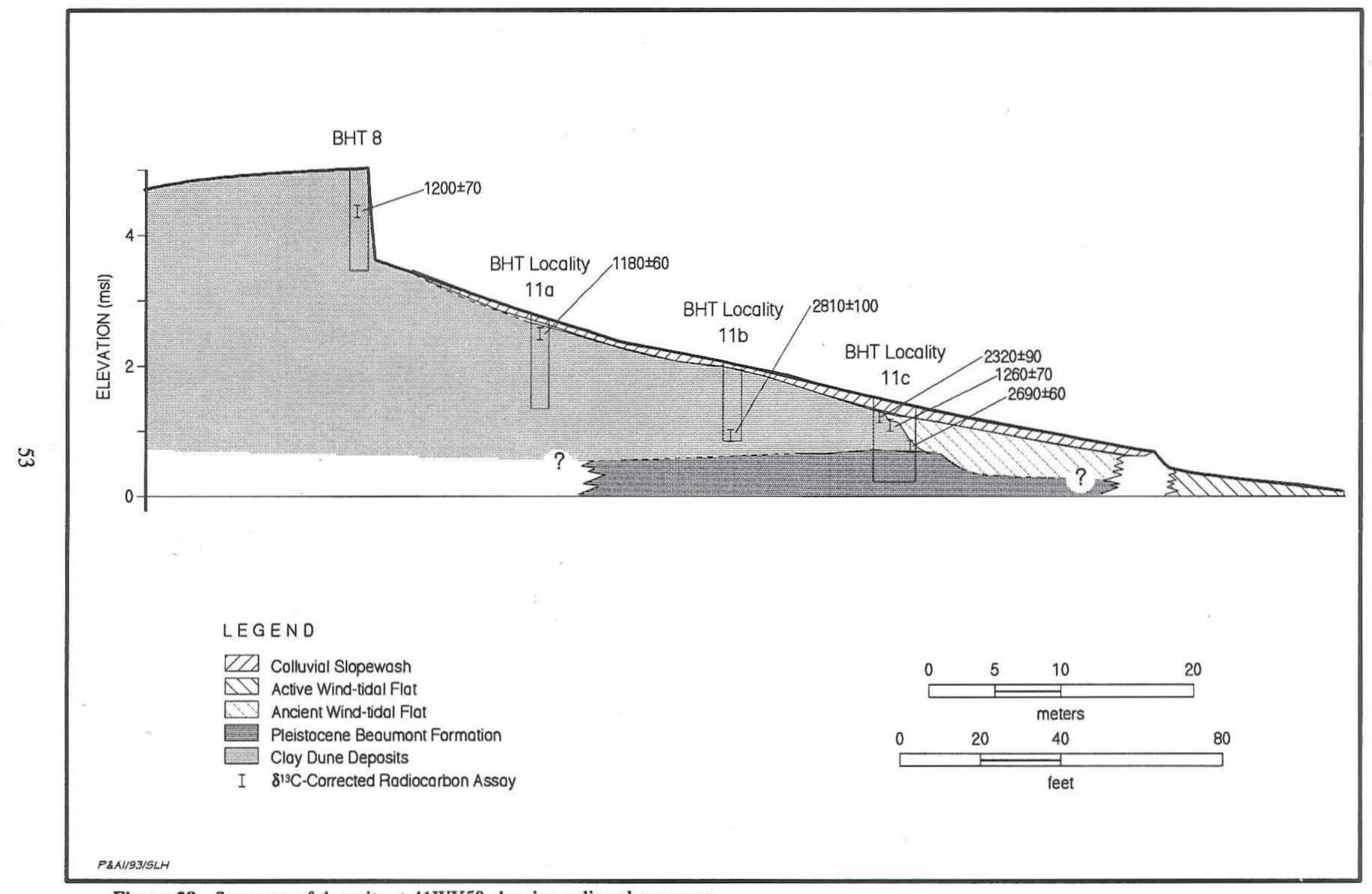

Figure 28. Sequence of deposits at 41 WY 50 showing radiocarbon assays. 


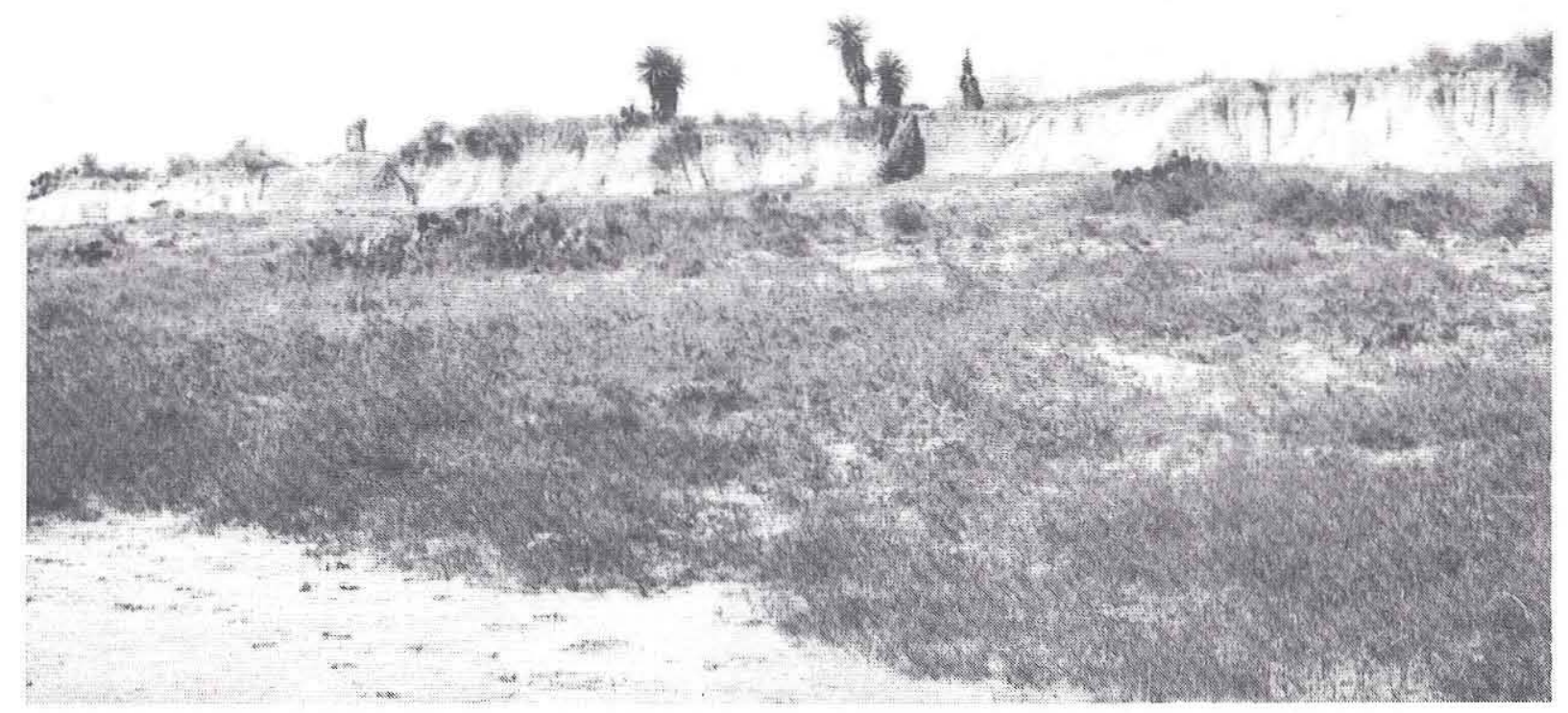

Figure 29. Truncated windward face and escarpment at the 41 WY50 clay dune.

stratigraphic position and lateral correlation of these sand lenses and radiocarbon assays, dune inundation by storm surges and floodwaters probably was frequent between 2300 and 1100 B.P. This period coincides with the interval of higher dune growth rates. The log probability graphs of sediment samples from this interval suggest severe mixing of sediments representing more than one depositional process (Figure 30). It is highly probable that the accelerated sedimentation rates were the result of wave energies providing additional sediments to the dune, suggesting that the floodwaters or surges of this period were less erosive and actually contributed sediment to the dune.

It also appears that during this period the active wind-tidal flat associated with the dune was at a higher elevation and farther landward, based on the presence of wind-tidal flat sediments that lap up onto the windward face of the dune in the profile of Backhoe Trench Locality 11c. Based on radiocarbon assays from the clay dune, the windtidal flat was deposited no earlier than 2300 B.P., and if the wind-tidal flat and the clay dune formed simultaneously, then the formation of the windtidal flat occurred between $2300-1100$ B.P. This suggests that sea level at that time may have been at least $1 \mathrm{~m}$ higher than the current mean sea level. A high sea stand could have affected the area in some important ways. One effect would have been more-frequent and more-intensive inundation of the clay dune by storm surges. The consequences of this would be similar to a storm surge occurring at high tide in a coastal area of high tidal fluctuations. At $41 \mathrm{WY} 50$, this may be represented by the many sand lenses and the increased rates of dune accretion.

\section{Evidence of a Late Holocene High Sea Stand}

Sea level curves are time-depth curves of relative land and sea level relationships derived from dates and elevations (below present mean sea level) of sensitive sea level indicators such as submerged peat deposits, beach ridges, and barriers on the continental shelf. A complete worldwide record of eustatic sea level for the late Quaternary 


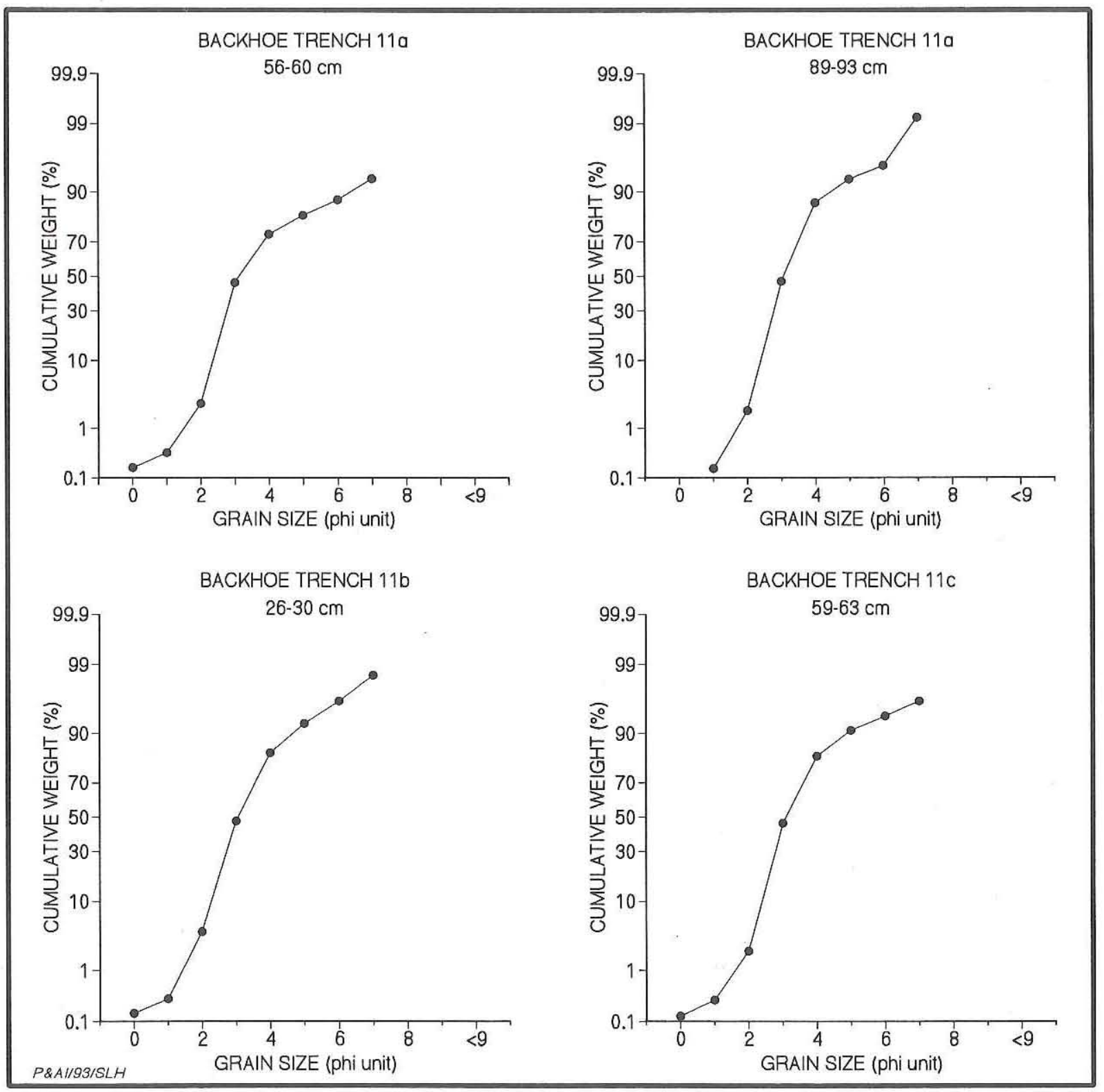

Figure 30. Log probability graph of the 41 WY50 clay dune sediment samples from 2300-1100 B.P. interval.

is difficult to obtain because of differing regional factors such as tectonism, isostatic rebound, diapirism, and compactional subsidence (Pirazolli et al. 1989). Many researchers have recommended that each coastal region develop its own independent sea level curve based on local data, rather than arbitrarily assuming a fit to a hypothetical worldwide curve (e.g., Kraft 1985; Morner 1984a).

Regardless of the eustatic sea level curve utilized, most Quaternary researchers agree that there was a noticeable and important decrease in the rate of eustatic sea level rise at ca. 7000 B.P. Around 3000-4000 B.P., another change evidently took place, but there is disagreement about what this change involved. Opinions fall into three realms of thought: (1) sea level reached its approximate present position at that time and has been rather stable since (Brown et al. 1980; Coleman and Smith 1964; Morton and Price 1987: 184); (2) sea level rise slowed markedly at ca. 3000-4000 B.P. but has steadily risen since (Kraft et al. 1987); or (3) sea level has been fluctuating 
above and below its present position since ca. $3000-4000$ B.P. The third hypothesis is undoubtedly the most controversial. Much of the evidence put forth for Holocene high stands has been proven to be the result of local uplift or the result of storm surges related to present mean sea level (Flint 1971:328). The presence or absence of evidence for a Holocene high sea stand also may be a factor of preservation. Davis and Clifton (1987) suggest that the preservation of physical evidence depicting previous sea levels is determined by sediment inputs and whether the shoreline is transgressive or progradational and wave or tidally dominated, all of which ultimately are controlled by the sea level itself.

Holocene high sea stands have been documented around the world, including western Africa (Einsele et al. 1974), Europe (Tooley 1978), Brazil (Suguio et al. 1992), and the Gulf Coast of Texas (Prewitt and Paine 1987). Some have related high sea stands to the Holocene climatic optimum, which would have triggered or accelerated the melting of continental glacial ice (Fairbridge 1961; Morner 1984b).

Prewitt and Paine (1987) document the remnants of a wind-tidal flat near Corpus Christi, Texas, the top of which lies $1.8 \mathrm{~m}$ above present mean sea level. This implies that when the windtidal flat was active mean sea level was at least 0.8 to $1.2 \mathrm{~m}$ higher than present. Remnants of a possible beach ridge composed of reworked shells also were observed at the same elevation. Radiocarbon assays on bulk sediment samples date the wind-tidal flat and high stand between 45003000 B.P. At site $41 \mathrm{WY} 50$, the remnants of an ancient wind-tidal flat were observed at the windward base of the clay dune. The sedimentary structures of this unit are identical to those of the active wind-tidal flat, which lies ca. 10-12 cm above present mean sea level. The absence of shell hash and the presence of very thin to medium beds of algal-bound mud suggest that this unit is not a storm deposit.

Because astronomical tides currently are negligible along the south Texas coast and probably have been since the formation of Padre Island, any wind-tidal flat formed after the creation of the barrier is an excellent indication of sea level at the time of its formation. The top of the abandoned wind-tidal flat is 1.1 to $1.2 \mathrm{~m}$ above present mean sea level. It is estimated that mean sea level was at least $1.0 \mathrm{~m}$ higher than present when the wind-tidal flat formed. It is interesting to note that Brown et al. (1980:76) make mention of wind-tidal flats at elevations of 1.0 to $1.5 \mathrm{~m}$ above mean sea level along the landward margin of the Laguna Madre but make no mention of their relationships to mean sea level. Radiocarbon assays on soil humates from the windward base of the clay dune suggest that the wind-tidal flat was deposited no earlier than 2300 B.P., well after the formation of Padre Island. If formation of the wind-tidal flat and the clay dune were simultaneous, then these assays suggest that a second Holocene high stand occurred along the south Texas coast between 23001100 B.P. and that a ca. 700-year low stand period may separate it from the earlier high stand proposed by Prewitt and Paine (1987).

Although the chronology of these two high stands along the south Texas coast needs to be refined through more assays directly from the elevated wind-tidal flats, it is interesting to compare them with the chronology of the three Holocene high stands documented along the coast of Brazil at 5100-3800 B.P., 3500-2700 B.P., and 2500 B.P., the last of which gradually dropped to the present-day level (Dominguez et al. 1987). It is estimated that these high stands represent rises of $3-5 \mathrm{~m}$ in sea level. These rises are immense compared to the estimated eustatic sea level rise along the south Texas coast; however, compactional subsidence may have masked the actual height of the Texas high sea stands.

Late Quaternary sea level curves for the northwestern Gulf of Mexico are derived largely from the depths and ages of geomorphic features submerged on the continental shelf (Curray 1960, 1965; Frazier 1974; Nelson and Bray 1970). None of these Gulf Coast curves support a sea level higher than that of the present day. However, the nature of the data utilized to create these curves is inherently biased against the documentation of sea levels higher than the present level because the data are derived from below present mean sea level.

While late Holocene high sea stands have been demonstrated for the south Texas coast, they may not be represented or demonstrable along other portions of the Gulf Coast due to differential preservation of key deposits. Wind-tidal flats are common along the south Texas coast because of 
compactional subsidence and lack of drainage from the mainland. These depositional environments appear to be key indicators of sea level; however, they are not present along the central and upper Texas coasts. Like the south Texas coast, most of the central and upper Texas coasts is transgressive, but the combination of both marine transgression due to compactional subsidence and increased runoff along the central and upper Texas coasts may have erased any evidence of a high sea stand. This is typical as sea level drops, the shoreline is exposed to subaerial dissection, and erosion increases (Davis and Clifton 1987:177). Subsidence and an ensuing high stand may be the reason why the earlier high stand proposed by Prewitt and Paine (1987) is not represented at 41WY50, especially since clay dune formation commenced during the intervening low stand.

\section{PALEOENVIRONMENTS}

The paleoenvironmental data are limited but clearly exhibit one dominant trend. The stable carbon isotope analysis demonstrates that the clay dune environment has been dominated by $\mathrm{C}_{4}$ and/or CAM plants throughout its history (Figure 31 ). A slight increase in $\mathrm{C}_{3}$ plants is depicted in the historic period and probably represents an infestation of mesquite related to overgrazing. The $\mathrm{C}_{4}$ plants are most likely salt-resistant grasses and CAM plants, such as prickly pear and yucca.

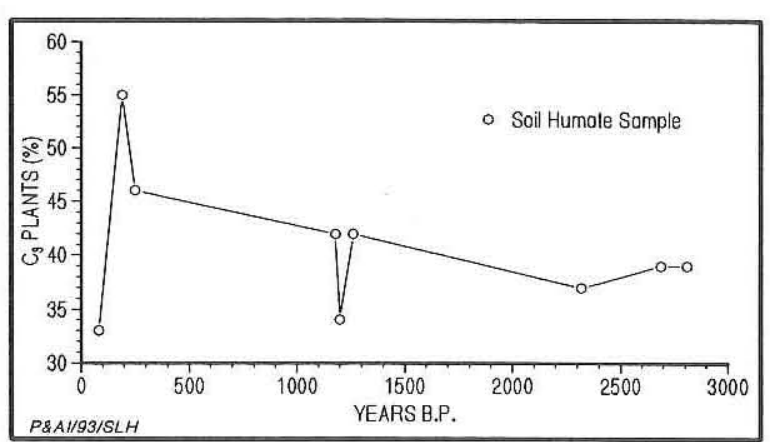

Figure 31. Estimates of $\mathrm{C}_{3}$ plant percentages from soil humate samples, 41WY50 and 41WY60.

The pollen and phytolith analyses yielded poor results (see Appendix D). Poor preservation is typical of the very alkaline sediments and high oxidation rates present in many south Texas environments.

\section{LANDSCAPE STABILITY AND RESOURCE AVAILABILITY}

The geomorphological and paleoenvironmental investigations and preliminary reconstruction of the late Holocene environment of the project area have some important implications for interpreting human utilization of the south Texas coast and the greater region of the Lower Rio Grande Valley. Most importantly, it is suggested here that environmental conditions limited utilization of much of the coastal zone during the late Holocene.

The late Holocene environment of the coastal zone underwent many dynamic changes, including the formation of Padre Island and the Laguna Madre, the transgression of the Rio Grande delta, and the extensive development of wind-tidal flats and clay dunes. These developments ultimately affected the kinds of resources available for exploitation and their distributions, which in turn influenced the organization of human subsistence strategies. Ricklis and Cox (1991) have correlated environmental changes along the central Texas coast with observed changes in human adaptation in the archeological record.

Estuaries and bays are relatively productive environments but can be short lived because they fill with sediments and become prograding terrestrial environments. The opposite is true on the south Texas coast; estuaries form due to subsidence but are quickly inundated with extremely saline water, continued subsidence transforms the estuarine environment to a hypersaline lagoonal environment, and therefore net productivity has probably decreased throughout the late Holocene for many parts of the south Texas coast.

The hypersaline environment of the Laguna Madre greatly limited the littoral resources available for utilization by hunting and gathering groups. Rangia cuneata and even Crassostrea virginica, which were dietary mainstays for prehistoric populations along the central and upper Texas coasts, are absent. Shellfish are limited to just a few hypersaline-tolerant species. Fish and waterfowl are abundant, however, and other molluscs and crustaceans are available nearshore off the barrier islands. Available plant foods probably were limited to prickly pear and yucca. However, the most limited resource and probably the key limiting factor to utilization of the coastal zone is freshwater. The semiarid climate of the area 
strongly dictates the amount and availability of potable water. Even after a rain, ponded water may become saline because of salts in the ground.

\section{THE ARCHEOLOGICAL RECORD OF THE COASTAL ZONE}

Geologic processes play an important role in the formation of the archeological record. Consideration must be given to the probability that archeological sites representing various cultural periods are not equally represented because of these processes. Coastal environments like those of the south Texas coast often create a temporal bias that favors the preservation of later occupations and discriminates against earlier occupations. The near absence of Paleoindian, early Archaic, and middle Archaic sites and materials along the south Texas coast is not an accident. This is due in large part to the eustatic sea level rise at the end of the Pleistocene and the compactional subsidence and marine transgression of the shoreline throughout the Holocene. Most of the coastal zone that was exposed and utilized by Paleoindian, early Archaic, and middle Archaic groups is now inundated by waters of the Gulf and Laguna Madre. Many highly productive environments, such as rivers, lakes, bays, and lagoons, are preserved on the wide shallow continental shelf of the western Gulf. Undoubtedly, these former terrestrial environments must have attracted human habitation during the late Pleistocene and early to middle Holocene. Submerged archeological sites from these time periods are quite common on the continental shelf (Stright 1990). The south Texas coast prior to changes during the late Holocene was probably a more hospitable place with diverse and abundant resources. Coastal bays and lagoons likely were not as saline as the Laguna Madre, since the barrier islands were not in place. It is likely that Archaic coastal adaptations like those on the central and upper Texas coasts developed on the south Texas coast during the early and middle Archaic. Evidence of these early adaptations is not preserved due to the continuing transgressive phase of the south Texas coast and earlier eustatic sea level rises.

Most of the coastal environments preserved on the south Texas coast are late-middle to late Holocene in age. These environments include clay dunes, wind-tidal flats, and barrier islands. All three are aggrading environments and should host late Archaic, Late Prehistoric, and Historic sites and materials. The presence or absence of any of these components reflects how the area was utilized prehistorically. The Holocene high sea stands probably did not affect the abundancy and diversity of resources, considering that the barrier islands and hypersaline conditions of the Laguna Madre were in place. However, access to the more basinward clay dunes may have been limited, which along with the dearth of resources limited the utilization of these environments even more. 


\section{HUMAN ADAPTATION AND THE ARCHEOLOGICAL RECORD OF THE LOWER RIO GRANDE VALLEY: A REVIEW AND ASSESSMENT FOR FUTURE INVESTIGATIONS}

This chapter reviews the results of the archeological investigations at 41WY50 and 41WY60 in light of the archeological record of the Lower Rio Grande Valley. The first part of the chapter reviews the human adaptation and land-use models proposed by Bousman et al. (1990) and discusses the implications of the 41WY50 and 41 WY 60 data. This is followed by a presentation of new interpretations, concepts, and proposals about human adaptations. The second part of the chapter consists of a review of the archeological record regarding the research potential and expectations for archeological sites and the implications for future investigations.

\section{Models of Human Adaptation and Land-Use for the Lower Rio Grande Valley}

Hester (1981) provided two of the earliest models of human adaptation for the Lower Rio Grande Valley in his overview of the cultural chronology and patterns of south Texas. His savanna adaptation reflects utilization of the interior savanna grassland and riparian zones, while his maritime pattern reflects use of the coastal bays, lagoons, and barrier islands. However, Hester (1981:122) noted that the models require adjustments with regard to temporal, spatial, and seasonal changes. Bousman et al. (1990) later elaborated on these concepts by testing three similar models of forager subsistence that incorporate optimal foraging theory and assume that territorial divisions limited access to subsistence resources. Bousman et al. (1990:37) viewed the procurement of subsistence resources and lithic raw materials as subject to the same kinds of constraints and proposed that the analysis of lithic assemblages could serve as a test of best fit between the three models of adaptation and the archeological record.
The lithic data, however, did not conclusively favor any one of the three models. The inability to confirm any of the models may be due to a number of different factors, as acknowledged by Bousman et al. (1990:130-133).

The additional data from sites $41 \mathrm{WY} 50$ and 41 WY 60 cannot clearly support or contradict any of the three models of Bousman et al. (1990), nor can a new model of human adaptation for the Lower Rio Grande Valley be properly supported at this time. However, the data do suggest that some of the concepts and assumptions used by Bousman et al. (1990) to define their models and resource zones, especially their characterization of the structure and productivity of the resources in the coastal zone, the treatment of the five zones as a single cultural region, and the use of forager-based models, need to be reevaluated. Such a reevaluation is presented below. The ideas discussed are far from complete, however, and they are synchronically limited, considering only the prehistoric record of the region since the formation of its modern environments (late Holocene), which archeologically includes only the Late Prehistoric period and possibly the late Archaic. Clearly, this discussion serves only as a springboard for future investigations, and adjustments for temporal and spatial variations will have to be made as new data are obtained.

The $41 \mathrm{WY} 50$ and $41 \mathrm{WY} 60$ data suggest that the productivity and economic resources of the coastal zone are far below the levels expected by Bousman et al. (1990), even considering that they recognized that species composition and diversity may have been affected by late Holocene environmental changes (Bousman et al. 1990:30). In general, coastal areas contain some of the most productive environments, such as estuaries or lagoons, where wave stress is 
reduced due to barriers and/or wide shallow continental shelves and freshwater discharge or run-off decreases salinity stress. Such reductions in biological stress result in increases in species diversity and productivity (Odum and Copeland 1974:36). Terrestrial game also inhabit these areas adding to the resource base. Less effort and risk could be involved in obtaining resources from these highly productive coastal ecosystems than in interior terrestrial systems, and in some coastal regions this could result in a greater degree of sedentism, higher population densities, and more-complex social organization (Perlman 1980:257). However, not all coastal zones are desirable human habitats. An important difference between the south Texas coast and the central and upper Texas coasts is the lack of freshwater drainage along the former, resulting in the development of broad wind-tidal flats and hypersaline conditions in the Laguna Madre. This greatly limits species diversity and the number of economic resources. The absence of potable water also is a critial limiting factor (Mallouf et al. 1977).

Evidence of prehistoric shellfish utilization in the Lower Rio Grande Valley is limited to one Crassostrea virginica midden, 41CF8, which is located near Brazos Santiago Pass where the exchange of waters between the Laguna Madre and the Gulf of Mexico results in decreased salinity levels. The only known oyster beds in the southern Laguna Madre occur in this area near the pass (Prewitt 1974:60). Fishing, which is noted in the ethnohistorical literature, appears to have been a more common subsistence activity but seems to have been confined to the Holocene delta of the Rio Grande (Salinas 1990). Archeological evidence of this is limited to one fish bone midden, 41CF29, which is located on a clay dune (Horse Island) at the northern margin of the Rio Grande delta (Prewitt 1974:60). However, fish otoliths are common at many sites, suggesting that the lack of fish bones may be a factor of preservation. It appears archeologically that the prehistoric utilization of the coastal zone of the Lower Rio Grande Valley was limited primarily to an area south of the Arroyo Colorado, along the lagoonal and Gulf margin of the modern Rio Grande delta. Freshwater sources are scarce north of the Arroyo Colorado, while south of it freshwater lakes and resacas are more common. It is no coincidence that the distribution of Rockport Complex sites reaches its southern limit at Baffin Bay where the salinity level of the Laguna Madre increases, drainage from the mainland ceases, and overall productivity of the coastal environments decreases markedly until the modem Rio Grande delta is reached approximately $100 \mathrm{~km}$ to the south.

The concept or treatment of the five zones as a single cultural region by Bousman et al. (1990), at least for the Late Prehistoric period, also may be inappropriate. Assuming that the Rio Grande acted as a cultural or territorial boundary between groups located south and north of the river, based on known artifact distributions from both sides of the Rio Grande, Bousman et al. (1990:36) treated the five environmental zones as a single cultural region or unit. Within this cultural region, a single group of foragers, or several groups with similar foraging subsistence strategies, may have operated, periodically utilizing dense resource patches which might have allowed for a degree of increased seasonal sedentism and/or territorial boundaries (Bousman et al. 1990:36). An alternative interpretation of the known archeological record, particularly lithic assemblages, and the resources of the five environmental zones suggests that the five zones defined by Bousman et al. (1990) may represent the margins of two cultural regions with differing subsistence and cultural patterns, separated by a vast area that was sparsely or intermittently utilized. This interpretation proposes that the lowland plain, and periodically the sand sheet, and their associated coastal boundaries were utilized on a very limited basis.

The lowland plain is where the vast majority of the archeological investigations and documented archeological sites associated with the HidalgoWillacy Drainage Ditch system are located. Only 8 of over 100 sites associated with the project have seen National Register testing, which is a testament to the poor context, limited integrity, and low artifact density of the sites in this zone. Based on this evidence from the archeological record, the utilization of this zone appears to have been greatly limited. Although game and plant food resources are available, their abundance is meager compared to the Rio Grande floodplain and delta zone to the south and areas to the north. Water sources are limited to playas, which are usually saline. The limited use of this zone may have been associated with the acquisition of salt from La Sal Vieja and El Sal del Rey, a pair of saline basins at the northern margin of the lowland plain, by groups both from the north and from the south. Historic aboriginal and Spanish use of these two lakes for salt procurement is well 
documented (Maliouf et al. 1977:49-51). Throughout the early history of south Texas, La Sal Vieja and El Sal del Rey provided the region with an endless supply of salt, and it is speculated that these historic quarrying endeavors were merely a continuation of earlier prehistoric salt-procurement activities.

North of the lowland plain and along the northern margin of the Lower Rio Grande Valley is the south Texas sand sheet, the archeological record of which is poorly known. Although very few archeological investigations have been carried out in the sand sheet, preliminary investigations have yielded sites with much higher artifact densities, particularly lithic materials, than sites in the lowland plain (see Mallouf et al. 1977:190). Bousman et al. (1990:143) note that the abundance of certain lithic artifacts, such as cores, suggests that a lithic source may be located somewhere within the sand sheet. However, much of the sand sheet is underlain by fluvio-deltaic deposits of the Lissie and Beaumont formations, which lack lithic materials. An alternative suggestion, which Bousman et al. (1990:131) also note, is that the sand sheet was utilized to a greater extent than the lowland plain by hunting and gathering groups. The sand sheet, with its oak mottes, provides a variety of economic resources, including deer, rabbits, javelina, prickly pear, and acorns. The interdunal areas, which capture rainfall and run-off, not only supply freshwater but also may have served as excellent natural traps from which hunters could have surprised or ambushed game attracted to the water sources.

Who these hunting and gathering peoples were is unclear. The spatial distribution of Toyah Horizon sites appears to reach its southern limit along the northern periphery of the sand sheet; however, the lack of Toyah sites farther to the south may be biased by the fact that the sand sheet has not been explored archeologically. Subsistence activities interpreted from Toyah sites and assemblages would be an ideal adaptation in the sand sheet, although it is doubtful that bison, an important economic resource for Toyah peoples, ever ranged this far south. Savanna-type adaptations are certainly represented in the ethnohistorical literature for groups who seasonally utilized prickly pear fields just north of the sand sheet (Campbell and Campbell 1981), and while the sand sheet does not contain dense prickly pear fields, other resources abound. Archeologically, the evidence is limited, but it does appear that the sand sheet was utilized from time to time (seasonally or during rainy periods) by foraging groups.

South of the lowland plain is the Rio Grande floodplain and delta zone of Bousman et al. (1990). The ethnohistorical record reveals that many aboriginal groups inhabited this zone and made use of its abundant resources (Salinas 1990:255), and it has been demonstrated archeologically that the coastal margin of this zone also was utilized intensively. It is within these zones that A. E. Anderson recorded a number of sites and collected artifacts. It is also within these zones that MacNeish (1947, 1958) defined and delineated the Late Prehistoric Brownsville Complex. Both the artifacts of the Anderson collection and MacNeish (1947, 1958) suggest connections between the Brownsville Complex and more-complex cultures to the south in Tamaulipas. Huastecan ceramic pottery and figurines, jadite beads, and obsidian are just some of the materials that demonstrate ties to the Huastecan peoples of northeastern Mexico. Another phenomenon that is largely restricted to these zones is the presence of cemeteries. In fact, Hester and Rodgers (1971:370) suggest that the Arroyo Colorado, which marks the northern boundary of these zones, may have held some sort of importance for the Brownsville Complex peoples since many of these cemeteries occur along this drainage.

Evidence of contact between groups north of the lowland plain and the Brownsville Complex is scant. Salinas (1990:19) suggests that the sparsely inhabited area served as a linguistic and cultural boundary. Mallouf et al. (1977:263) note two Perdiz points from a site in the lowland plain of Hidalgo County, but other than these two arrow points, evidence is lacking. Artifacts associated with the Brownsville Complex are not found in assemblages from sites to the north (MacNeish 1947:7); however, shell ornaments and artifacts have been found farther south in the Huastecan area (Ekholm 1944) and westward into the Mexican states of Coahuila and Chihuahua (Avelyra Arroyo de Anda et al. 1956; MacNeish 1958).

It appears that the Brownsville Complex may represent Huastecan (Panuco Period VI) peoples or peoples living on the frontier of Huastecan influence and operating as a periphery or semiperiphery player in a macrosystem with the Huastecan area as the core (see Baugh 1982 for macrosystem definition). This interpretation suggests that the tradition of viewing the cultural adaptations and patterns of the Lower Rio Grande Valley, particularily of the Late 
Prehistoric period, as a part of a long tradition of indigenous hunters and gatherers may be inappropriate. This concept leads to the third potential problem with the models proposed by Bousman et al. (1990).

Bousman et al. (1990:26-36) utilized the resource structure and the high effective temperature or ET value (the annual mean and seasonal distribution of solar radiation) of the Lower Rio Grande Valley to characterize human adaptations in the region in terms of forager systems (e.g., Binford 1980), although two of the models, Models II and III, allowed for increased seasonal sedentism and the development of group territories in highly productive and predictable resource patches. However, it appears that resource densities and distributions in the Lower Rio Grande Valley overall are atypical of environments with high ET values, rendering the presumption of a foraging adaptation tenuous.

Ricklis (1990:169-171) also questions the assumption that the Lower Rio Grande Valley prehistoric inhabitants were highly mobile foragers, particularily for the Rio Grande floodplain and delta zone and/or Brownsville Complex. Ricklis (1990: 171) alludes to the fact that the elaborate shell industry of the Lower Rio Grande Valley is not indicative of a highly mobile foraging population. The cemeteries also suggest that Brownsville Complex peoples had strong territorial ties, a territory whose northern boundary may have been marked by the Arroyo Colorado. The highly productive Rio Grande delta and floodplain may have led to a greater intensity of use and more-frequent reoccupation of the zone by foraging group(s), resulting in the establishment of cemeteries. However, the exclusion of habitation areas within these formal burial areas is suggestive of a more complex pattern of sedentism and social structure (Goldstein 1981).

Ricklis (1990:171-172) suggests that a model based on a less mobile collecting strategy may be more appropriate for the Lower Rio Grande Valley. Salinas (1990:216) notes that during the winter fish were dried and stored, a practice more characteristic of collectors than foragers. The connections between the Brownsville Complex and the Huasteca, the shell industry, and the formal cemeteries appear to represent a society of more complexity than small bands of foragers. From this perspective, it appears that the Brownsville Complex represents logistical collectors, or possibly simple horticulturalists, who may have supplemented their diet with fish and other marine resources during the winter months.

\section{Research Goals and Assessment of the Archeological Record for the Lower Rio Grande Valley}

The preceding review of human adaptations is temporally limited, the result of a poorly understood and biased archeological record. This is only one of many important data gaps and research needs that should be addressed in the Lower Rio Grande Valley by future investigations. Some recent archeological overviews (e.g., Black 1989; Ricklis 1990) have noted some of these research needs as part of an overall larger south Texas or coastal Texas region, but they do not single-handedly or specifically address the research needs of the Lower Rio Grande Valley. A single point is common in all the reviews, however, and that is the basic need for meaningful archeological data.

An understanding of the region's cultural chronology is an obvious point of concern. This goal is hampered by a lack of datable materials (i.e., charcoal), well-defined stratigraphy, and timediagnostic artifacts at most sites. Collins et al. (1989) recommend that radiocarbon dating of soil and sediment humates and optical luminescence dating of sediments can provide important chronological data for poorly preserved and artifact-sparse sites. These techniques may provide chronological control not only over geomorphic events but also to some extent over cultural events.

There is also a tremedous need for archeological data predating the late Archaic. An absolute chronology does not exist, and tool types and assemblages are poorly defined. This need for data, however, is hindered by the fact that late Pleistocene and early to middle Holocene landforms and surfaces are so poorly preserved. Upland Pleistocene surfaces were severely deflated during the early and middle Holocene. Pleistocene and early Holocene coastlines have subsided or have been inundated by rising sea levels. Many environments that probably attracted human habitation, such as rivers, lakes, bays, and lagoons, are preserved on the wide shallow continental shelf of the western Gulf of Mexico, and it is likely that many Paleoindian and early to middle Archaic sites are preserved within these environments. Coastal bays and lagoons probably were not as saline as the modern Laguna Madre since the barrier islands were not in place, resulting in a greater diversity of 
resources and the potential for greater utilization by humans. Therefore, even if the early archeological record of the region was preserved, the terrestrial record may be limited as populations probably would have been drawn to the resource-dense coastal areas.

The Late Prehistoric period is better known than the preceding periods; however, many questions remain. The tentatively defined Brownsville Complex lacks thoroughly excavated sites and radiocarbon assays establishing an absolute chronology. An important beginning to understanding this poorly understood complex would be a thorough analysis of the A. E. Anderson collection at the Texas Archeological Research Laboratory. It should be analyzed and compared to artifact assemblages from Tamaulipas, South Texas, and the Falcon Reservoir area. The elaborate shell industry should be compared to other shell ornament and tool industries from the Corpus Christi area and the coastal Tamaulipas (Huastecan) area. Shell species should be identified, as well as their sources or ranges. Manufacturing methods and stages need to be understood and delineated, and their presence in regions outside the Lower Rio Grande Valley needs to be studied. Source analysis of exotic materials such as ceramics and obsidian through petrography and neutron activitation or $\mathrm{x}$-ray diffraction should be carried out. Although several cemeteries and burials have been documented and attributed to the Brownsville Complex, none of the human remains have been dated by radiocarbon assay. In addition to radiocarbon dating, stable carbon and nitrogen isotopic analyses should be carried out to infer dietary patterns. It is also important that habitation sites be found and documented. Such analyses and studies could further our understanding of this cultural manifestation, including its mortuary and subsistence practices, material culture, and exchange systems, and may establish whether the Brownsville Complex is a valid concept.

In the sand sheet area to the north, very little is known about the Late Prehistoric period. Even the most modest data on sites and tool assemblages would greatly increase understanding of the archeological record in this area and could shed some light on what Late Prehistoric cultural manifestations are represented.

Lithic raw materials are rare in the Lower Rio Grande Valley. It is important to understand how this affected the procurement of raw materials and the manufacture, curation, and discard of lithic artifacts.
Micro-use-wear analyses should be included as part of these lithic studies, and the importance of shell as a lithic substitute also should be considered. An important aspect of these studies would be the manufacture, temporal variance, and function of the many small triangular bifaces that dominate assemblages in the region.

Features, primarily shallow basin-shaped hearths, are poorly understood. A better understanding of their use lives and functions may be obtained from micromorphological studies of feature block thin sections. This technique has shown great promise for identifying hearth fuel and the nature of the feature fill (see Appendix E).

Because Holocene environmental changes in the Lower Rio Grande Valley have played such an important role in site formation, a rigorous geomorphological/paleoenvironmental program should be a part of any archeological investigation. Such investigations could include, but not be limited to, detailed documentation of significant profiles, dating of soils and sediments, stable carbon isotope analysis on soil humates, micro-faunal analysis, and pollen and phytolith analyses of selected samples.

Little of the archeological data generated thus far from the previous investigations carried out in the Lower Rio Grande Valley can thoroughly address these issues. New and meaningful data are sorely needed and can be obtained only from new and different sites. It is well established that many older environments are not preserved in the Lower Rio Grande Valley and that some areas, such as the lowland plain and parts of the coast, have little potential for yielding the kinds of sites needed to address the issues discussed above. It is recommended that any future survey efforts focus intensively on limited areas of high site potential rather than on extensive areal coverage.

In the case of Paleoindian and early to middle Archaic sites, few areas in the Lower Rio Grande Valley have the potential to yield these early sites intact. The only preserved terrestrial environment where these early occupations potentially may be found is the Holocene alluvial fill of the Rio Grande Valley. Previous geomorphological studies of the Rio Grande Valley suggest that alluvial deposits predating the late Holocene are preserved (Boyd et al. 1994; Kibler and Freeman 1993). If this is the case, then the potential for preserved Paleoindian and early to middle Archaic sites is high. Survey efforts on the Rio Grande floodplain and associated 
Holocene terraces should make use of deep mechanical trenching, particularily on levees overlooking resacas. There is also a limited potential for the preservation of early occupation sites in some of the larger, more stable dunes of the sand sheet. Deep testing is recommended for these larger dunes, as well as the close inspection of adjacent interdunal areas for the presence of early time-diagnostic materials that may be eroding out at the base of the dunes.

Late Archaic and Late Prehistoric sites are much more common, as late Holocene environments are better preserved across the Lower Rio Grande Valley. Prewitt (1974) defines five topographic/ geomorphic environments where sites tend to cluster: clay dune-laguna, clay dune-lake or playa, resacalaguna, resaca, and barrier island. Another specific environment can be added to this list, that being the lower reaches of the Arroyo Colorado. Burials and cemeteries appear to be common along this drainage. Levees should be extensively tested by hand and backhoe trenches. Survey efforts should focus intensively on all six of these areas, utilizing shovel tests and backhoe trenches.

Chronological data are not the only meaningful information needed. The most productive sites are those that are well preserved and relatively artifact and ecofact dense. Sites that occur within the previously mentioned six environments often are disturbed and artifact poor. Past investigations (e.g., Hall et al. 1987) have defined sites on as little as the presence of bone fragments, unmodified shells, and burned clay lumps in combination. While this definition of a site should not be abandoned, sites like this have little research potential. Further testing and excavation efforts in the region should be reserved for sites likely to contain temporal data (e.g., projectile points, ceramics, human remains, and charcoal) and artifact- or ecofact-dense components. Testing and excavation of sites lacking these characteristics should be avoided.

To summarize these recommendations, an intensive level of effort is proposed for certain areas and environments in the Lower Rio Grande Valley where the potential for intact sites with relatively dense artifacts and/or ecofacts is high. Two areas, the Holocene valley fill of the Rio Grande and the larger stabilized sand dunes of the sand sheet, offer the best potential for the presence of sites predating the late Archaic and should be inspected through deep mechanical testing and shovel tests. Smaller environments, such as clay dunes and levees overlooking resacas, within and outside these larger areas offer the best potential for containing intact artifact-dense sites, cemeteries, and isolated burials. Efforts focusing on these areas should make extensive use of shovel testing and mechanical testing to locate and evaluate sites. The costs for such intensive efforts can be offset by the fact that the overall areal coverage is limited, as areas of low site potential and artifact-poor sites are excluded. Costs can be offset further by concentrating excavation efforts on relatively small numbers of sites with relatively high artifact or ecofact densities, intact stratigraphy, and overall high research potential. At the same time, however, large areas within these few chosen sites should be excavated to add sorely needed archeological data. 


\section{REFERENCES CITED}

Anderson, A. E.

1932 Artifacts of the Rio Grande Delta Region. Bulletin of the Texas Archeological and Paleontological Society 4:29-31.

Andrews, Jean

1981 Texas Shells: A Field Guide. University of Texas Press, Austin.

Avelyra Arroyo de Anda, Luis, M. Maldonado-Koerdell, and P. Martinez del Rio

1956 Cueva de la Candelaria. Volumen I. Memorias del Instituto Nacional de Antropologia e Historia, V. Mexico, D.F.

Barnes, Virgil E.

1976 Geologic Atlas of Texas, McAllenBrownsville Sheet. Bureau of Economic Geology, The University of Texas at Austin.

Baugh, Timothy G.

1982 Edwards I (34BK2): Southern Plains Adaptations in the Protohistoric Period. Studies in Oklahoma's Past No. 8. Oklahoma Archaeological Survey, Norman.

Bender, Margaret M.

1968 Mass Spectrometric Studies of Carbon 13 Variations in Corn and Other Grasses. Radiocarbon 10:468-472.

Bettis, E. Arthur, III

1984 New Conventions for the Designation of Soil Horizons and Layers. Plains Anthropologist 29(103):57-59.

Binford, Lewis R.

1980 Willow Smoke and Dogs' Tails: Hunter-
Gatherer Settlement Systems and Archaeological Site Formation. American Antiquity 45(1):4-20.

Birkeland, Peter W.

1984 Soils and Geomorphology. Oxford University Press, Oxford.

Black, Stephen L.

1989 South Texas Plains. In From the Gulf to the Rio Grande: Human Adaptation in Central, South, and Lower Pecos Texas, by Thomas R. Hester, Stephen L. Black, D. Gentry Steele, Ben W. Olive, Anne A. Fox, Karl J. Reinhard, and Leland C. Bement, pp. 39-62. Research Series No. 33. Arkansas Archeological Survey, Fayetteville.

Blair, W. Frank

1950 The Biotic Provinces of Texas. The Texas Journal of Science 2(1):93-117.

Bousman, C. Britt, Steve A. Tomka, and Gail L. Bailey 1990 Prehistoric Archeology and Paleoenvironments in Hidalgo and Willacy Counties, South Texas: Results of the Phase II Test Excavations. Reports of Investigations No. 76. Prewitt and Associates, Inc., Austin.

Boyd, Douglas K., Andrés Tijerina, Karl W. Kibler, Amy C. Earls, and Martha Doty Freeman

1994 Pharr-Reynosa International Bridge: Continued Archeological and Historical Research at El Capote Ranch Community, Hidalgo County, Texas. Reports of Investigations No. 97. Prewitt and Associates, Inc., Austin. 
Brown, L. F., Jr., J. L. Brewton, T. J. Evans, J. H. McGowen, W. A. White, C. G. Groat, and W. L. Fisher

1980 Environmental Geologic Atlas of the Texas CoastalZone-Brownsville-Harlingen Area. Bureau of Economic Geology, The University of Texas at Austin.

Buol, S. W., F. D. Hole, and R. J. McCracken

1980 Soil Genesis and Classification. 2nd ed. Iowa State University Press, Ames.

Butzer, Karl W.

1982 Archaeology as Human Ecology. Cambridge University Press, Cambridge.

Campbell, T. N.

1947 The Johnson Site: Type Site of the Aransas Focus of the Texas Coast. Bulletin of the Texas Archeological and Paleontological Society 18:40-75.

1988 Indians of Southern Texas and Northeastern Mexico: Selected Writings of Thomas Nolan Campbell. Texas Archeological Research Laboratory with the cooperation of the Department of Anthropology, the College of Liberal Arts, and the Institute of Latin American Studies, The University of Texas at Austin.

Campbell, T. N., and T. J. Campbell

1981 Historic Indian Groups of the Choke Canyon Reservoir and Surrounding Area, Southern Texas. Choke Canyon Series 1. Center for Archaeological Research, The University of Texas at San Antonio.

Cerling, Thure E.

1984 The Stable Isotopic Composition of Modern Soil Carbonate and Its Relationship to Climate. Earth and Planetary Science Letters 71:229-240.

Cerling, Thure E., and Richard L. Hay

1986 An Isotopic Study of Paleosol Carbonates from Olduvai Gorge. Quaternary Research 25:63-78.

Cerling, T. E., J. Quade, Y. Wang, and J. R. Bowman 1989 Carbon Isotopes in Soils and Palaeosols as Ecology and Palaeoecology Indicators. Nature 341:138-139.
Coffey, George N.

1909 Clay Dunes. Journal of Geology 17:754755 .

Coleman, James M., and William G. Smith

1964 Late Recent Rise of Sea Level. Geological Society of America Bulletin 75:833-840.

Collins, $\mathrm{K}$.

1984 Status and Management of Native South Texas Brushlands. U.S. Fish and Wildlife Service, Ecological Service, Corpus Christi, Texas.

Collins, Michael B., Grant D. Hall, and C. Britt Bousman 1989 Archaeological Applications of Geochronological Techniques in Southern Texas. La Tierra 16(1):14-27.

Collins, Michael B., Thomas R. Hester, and Frank A. Weir

1969 The Floyd Morris Site (41CF2), a Prehistoric Cemetery Site in Cameron County, Texas. Part I in Two Prehistoric Cemetery Sites in the Lower Rio Grande Valley of Texas, by Thomas Roy Hester, Michael B. Collins, Frank A. Weir, and Frederick Ruecking, Jr. Bulletin of the Texas Archeological Society 40:119-146.

Corbin, James E.

1963 Archeological Materials from the Northern Shore of Corpus Christi Bay, Texas. Bulletin of the Texas Archeological Society 34:5-30.

Craig, $\mathrm{H}$.

1953 The Geochemistry of the Stable Carbon Isotopes. Geochimica et Cosmochimica Acta 3:53-92.

Curray, Joseph R.

1960 Sediments and History of Holocene Transgression, Continental Shelf, Northwest Gulf of Mexico. In Recent Sediments, Northwest Gulf of Mexico, edited by F. P. Shepard, F. B. Phleger, and T. H. van Andel, pp. 221266. American Association of Petroleum Geologists, Tulsa.

1965 Late Quaternary History, Continental Shelves of the United States. In The Quaternary of the United States, edited by H. E. Wright, Jr., and David G. Frey, pp. 723-735. 
Princeton University Press, Princeton, New Jersey.

Davis, Richard A., Jr., and H. Edward Clifton

1987 Sea-Level Change and the Preservation Potential of Wave-Dominated and TideDominated Coastal Sequences. In Sea-Level Fluctuation and Coastal Evolution, edited by D. Nummedal, O. H. Pilkey, and J. D. Howard, pp. 167-178. Special Publication No. 41. Society of Economic Paleontologists and Mineralogists, Tulsa.

Day, D. William

1981 An Assessment of Archeological Sites $41 W Y 71$ and 41WY72, Willacy County, Texas. Reports of Investigations No. 17. Prewitt and Associates, Inc., Austin.

Day, D. William, Jane Laurens-Day, and Elton R. Prewitt 1981 Cultural Resources Survey and Assessments in Portions of Hidalgo and Willacy Counties, Texas. Reports of Investigations No. 15. Prewitt and Associates, Inc., Austin.

Deines, P.

1980 The Isotopic Composition of Reduced Organic Carbon. In Handbook of Environmental Geochemistry, Vol 1: The Terrestrial Environment, edited by P. Fritz and J. C. Fontes, pp. 329-406. Elsevier, Amsterdam.

Dominguez, J. M. L., Louis Martin, and Abilio C. S. P. Bittencourt

1987 Sea-level History and Quaternary Evolution of River Mouth-Associated Beach-Ridge Plains Along the East-Southeast Brazilian Coast: A Summary. In Sea-Level Fluctuation and Coastal Evolution, edited by D. Nummedal, O. H. Pilkey, and J. D. Howard, pp. 115-127. Special Publication No. 41. Society of Economic Paleontologists and Mineralogists, Tulsa.

Dzurec, R. S., T. W. Boutton, M. M. Caldwell, and B. N. Smith

1985 Carbon Isotope Ratios of Soil Organic Matter and Their Use in Assessing Community Composition Changes in Curlew Valley, Utah. Oecologia 66:17-24.
Eickmeier, William G., and Margaret M. Bender

1976 Carbon Isotope Ratios of Crassulacean Acid Metabolism Species in Relation to Climate and Phytosociology. Oecologia 25:341-347.

Einsele, G., D. Herm, and H. U. Schwarz

1974 Sea Level Fluctuation During the Past 6,000 Years of the Coast of Mauritania. Quaternary Research 4:282-289.

Ekholm, G. F.

1944 Excavations at Tampico and Panuco in the Huasteca, Mexico. Anthropological Papers of the American Museum of Natural History 38, Part 5.

Espey, Huston and Associates, Inc.

1990 Remote-Sensing Survey, Diver Verification and Archaeological Testing, Brownsville Ship Channel Entrance and Vicinity, Cameron County, Texas. Document No. 900161. Espey, Huston and Associates, Inc., Austin.

Fairbridge, Rhodes W.

1961 Eustatic Changes in Sea-Level. In Physics and Chemistry of the Earth, Vol. 4, edited by L. H. Ahrends, Frank Press, Kalervo Rankama, and S. K. Runcorn, pp. 99-195. Pergamon Press, New York.

Fisk, H. N.

1959 Padre Island and the Laguna Madre Flats, Coastal South Texas. Proceedings of the Second Coastal Geography Conference, pp. 103-151. Louisiana State University, Baton Rouge.

Flint, Richard Foster

1971 Glacial and Quaternary Geology. John Wiley and Sons, Inc., New York.

Folk, Robert L.

1980 Petrology of Sedimentary Rocks. Hemphill Publishing Co., Austin.

Frazier, David E.

1974 Depositional-Episodes: Their Relationship to the Quaternary Stratigraphic Framework in the Northwestern Portion of the Gulf Basin. Geological Circular 74-1. Bureau of 
Economic Geology, The University of Texas at Austin.

Galloway, W. E., and David K. Hobday

1983 Terrigenous Clastic Depositional Systems: Applications to Petroleum, Coal, and Uranium Exploration. Springer-Verlag, New York.

Goldstein, Lynne Gail

1981 One Dimensional Archaeology and MultiDimensional People: Spatial Organization and Mortuary Practices. In The Archaeology of Death, edited by R. Chapman, I. Kinnes, and K. Randsborg, pp. 53-69. Cambridge University Press, Cambridge.

Haas, Herbert, Vance Holliday, and Robert Stuckenrath 1986 Dating of Holocene Stratigraphy with Soluble and Insoluble Organic Fractions at the Lubbock Lake Archaeological Site, Texas: An Ideal Case Study, Radiocarbon 28(2A): 473-485.

Hall, Grant D., Michael B. Collins, and Elton R. Prewitt 1987 Cultural Resources Investigations Along Drainage Improvements, Hidalgo and Willacy Counties, Texas: 1986 Investigations. Reports of Investigations No. 59. Prewitt and Associates, Inc., Austin.

Hall, Grant D., and Kerry A. Grombacher

1974 An Assessment of the Archeological and Historical Resources to be Affected by the Brazos Island Harbor Waterway Project, Texas. Research Report No. 30. Texas Archeological Survey, The University of Texas at Austin.

Headrick, Pamela J.

1991 The Archeology of 41NU11, The Kirchmeyer Site, Nueces County, Texas: Long-Term Utilization of a Coastal Clay Dune. Unpublished Master's thesis, The University of Texas at Austin.

Hester, Thomas R.

1971 Notes on Baked Clay Objects from the Texas Coast. University of South Carolina, Institute of Archeology and Anthropology Notebook 3(1):15-17.
1976 Hunters and Gatherers of the Rio Grande Plain and Lower Coast of Texas. Center for Archaeological Research, The University of Texas at San Antonio.

1981 Tradition and Diversity Among the Prehistoric Hunters and Gatherers of Southern Texas. Plains Anthropologist 26(92):119128.

1993 Letter from Thomas R. Hester dated August 10,1993 , providing results of obsidian trace element analysis for Texas Obsidian Project (TOP) specimens 166 and 167. On file, Prewitt and Associates, Inc., Austin.

Hester, Thomas R., and R. W. Rodgers

1971 Additional Data on the Burial Practices of the Brownsville Complex. The Texas Journal of Science 22(4):367-372.

Hester, Thomas R., and Frederick Ruecking, Jr.

1969 Additional Materials from the Ayala Site, a Prehistoric Cemetery Site in Hidalgo County, Texas. Part II in Two Prehistoric Cemetery Sites in the Lower Rio Grande Valley of Texas, by Thomas Roy Hester, Michael B. Collins, Frank A. Weir, and Frederick Ruecking, Jr. Bulletin of the Texas Archeological Society 40:119-146.

Huebner, Jeffery A.

1986 Texas Coastal Clay Objects: Hypotheses Testing by Archaeological Experimentation. La Tierra 13(2):32-37.

Huffman, George G., and W. Armstrong Price

1949 Clay Dune Formation Near Corpus Christi, Texas. Journal of Sedimentary Petrology 19(3):118-127.

Hunt, C. B.

1974 Natural Regions of the United States and Canada. W. H. Freeman and Co., San Francisco.

Jahrsdoerfer, Sonja E., and David M. Leslie, Jr.

1988 Tamaulipan Brushland of the Lower Rio Grande Valley of South Texas: Description, Human Impacts, and Management Options. Biological Report 88(36). U.S. Fish and 
Wildlife Service, Washington, D.C.

Jelks, Edward B.

1978 Diablo Range. In Chronologies in New World Archaeology, edited by R. E. Taylor and Clement W. Meighan, pp. 71-112. Academic Press, New York.

Johnston, Marshall Conring

1955 Vegetation of the Eolian Plain and Associated Coastal Features of Southern Texas. Unpublished Ph.D. dissertation, The University of Texas at Austin.

Kelley, J. Charles

1947 The Cultural Affiliations and Chronological Position of the Clear Fork Focus. American Antiquity 13(2):97-109.

Kibler, Karl W., and Martha Doty Freeman

1993 Preliminary Cultural Resources Investigations for the Pharr-Reynosa International Bridge, Hidalgo County, Texas. Reports of Investigations No. 90. Prewitt and Associates, Inc., Austin.

Kraft, John C.

1985 Marine Environments: Paleogeographic Reconstructions in the Littoral Region. In Archaeological Sediments in Context, edited by Julie K. Stein and William R. Farrand, pp. 111-125. Center for the Study of Early Man, Institute for Quaternary Studies, University of Maine at Orono.

Kraft, John C., Michael J. Chrzastowski, Daniel F. Belknap, Marguerita A. Toscano, and Charles H. Fletcher III

1987 The Transgressive Barrier-Lagoon Coast of Delaware: Morphostratigraphy, Sedimentary Sequences and Responses to Relative Rise in Sea Level. In Sea-Level Fluctuation and Coastal Evolution, edited by D. Nummedal, O. H. Pilkey, and J. D. Howard, pp. 129143. Special Publication No. 41. Society of Economic Paleontologists and Mineralogists, Tulsa.

Livingston, D. A., and W. D. Clayton

1980 An Altitudinal Cline in Tropical African Grass Floras and Its Paleoecological Significance. Quaternary Research 13:392-402.
MacNeish, Richard S.

1947 A Preliminary Report on Coastal Tamaulipas, Mexico. American Antiquity 13(1):1-15.

1958 Preliminary Archaeological Investigations in the Sierra de Tamaulipas, Mexico. Transactions of the American Philosophical Society 48:6.

Mallouf, Robert J., Barbara J. Baskin, and Kay Killen 1977 A Predictive Assessment of Cultural Resources in Hidalgo and Willacy Counties, Texas. Survey Report 23. Office of the State Archeologist, Texas Historical Commission, Austin.

Mallouf, Robert J., and Anthony N. Zavaleta

1979 The Unland Site: A Prehistoric Group Burial from Laguna Atascosa National Wildlife Refuge, Cameron County, Texas. Special Report 25. Office of the State Archeologist, Texas Historical Commission, Austin.

Mason, J. Alden

1935 The Place of Texas in Pre-Columbian Relationships Between the United States and Mexico. Bulletin of the Texas Archeological and Paleontological Society 7.

Mercado-Allinger, Patricia A.

1983 Survey, Testing, and Assessment of Cultural Resources in Portions of Willacy County Drainage District No. 1, Willacy County, Texas. Reports of Investigations No. 20. Prewitt and Associates, Inc., Austin.

Morner, N. A.

1984a Eustasy, Geoid Changes, and Multiple Geophysical Interaction. In Catastrophes and Earth History, edited by W. A. Berggren and J. A. Van Couvering, pp. 395-415. Princeton University Press, Princeton, New Jersey.

1984b Planetary, Solar, Atmospheric, Hydrospheric and Endogene Processes as Origin of Climatic Changes on the Earth. In Climatic Changes on a Yearly to Millenial Basis, edited by N. A. Morner and W. Karlen, pp. 483-507. Reidel Publishing Co., Dordrecht, Holland. 
Morton, Robert A., and W. Armstrong Price

1987 Late Quaternary Sea-Level Fluctuations and Sedimentary Phases of the Texas Coastal Plain and Shelf. In Sea-Level Fluctuation and Coastal Evolution, edited by D. Nummendal, O. H. Pilkey, and J. D. Howard, pp. 181-198. Special Publication No. 41. Society of Economic Paleontologists and Mineralogists, Tulsa.

Nambudiri, E. M. V., W. D. Tidwell, B. N. Smith, and N. P. Hebbert

$1978 \mathrm{~A} \mathrm{C}_{4}$ Plant from the Pliocene. Nature 276: 816-817.

Natelhoffer, K. J., and B. Fry

1988 Controls on Natural Nitrogen-15 and Carbon13 Abundances in Forest Soil Organic Matter. Soil Science Society of America Journal 52: 1633-1640.

National Oceanic and Atmospheric Administration

1993 Tide and Water Levels Records for Port Mansfield, Texas, Station No. 6778490, Jan.March 1993. NOAA/National Ocean Service, U.S. Department of Commerce, Rockville, Maryland.

Natural Fibers Information Center

1987 The Climates of Texas Counties. Bureau of Business Research in cooperation with the Office of the State Climatologist, Texas A\&M University, The University of Texas at Austin.

Nelson, H. F., and E. E. Bray

1970 Stratigraphy and History of the Holocene Sediments in the Sabine-High Island Area, Gulf of Mexico. In Deltaic Sedimentation, Modern and Ancient, edited by J. P. Morgan and R. H. Shaver, pp. 48-77. Special Publication 15. Society of Economic Paleontologists and Mineralogists, Tulsa.

Norwine, Jim, and Ralph Bingham

1986 Frequency and Severity of Droughts in South Texas: 1900-1983. In Livestock and Wildlife Management During Drought, edited by R. D. Brown, pp. 1-17. Caesar Kleberg Wildlife Research Institute, Kingsville, Texas.
Odum, H. T., and B. J. Copeland

1974 A Functional Classification of the Coastal Systems of the United States. In Coastal Ecological Systems of the United States, Vol. l, edited by H. T. Odum, B. J. Copeland, and E. A. McMahan, pp. 5-84. The Conservation Foundation, Washington, D.C., in cooperation with the National Oceanic and Atmospheric Administration, Office of Coastal Environment, Washington, D.C.

Pearson, G. W., and M. Stuiver

1993 High-Precision Bidecadal Calibration of the Radiocarbon Time Scale 500-2500 B.C. Radiocarbon 35:25-33.

Perlman, Stephen M.

1980 An Optimum Diet Model, Coastal Variability and Hunter-Gatherer Behavior. In Advances in Archaeological Method and Theory, Vol. 3, edited by Michael B. Schiffer, pp. 257310. Academic Press, New York.

Pirazolli, P. A., D. R. Grant, and P. L. Woodworth

1989 Trends of Relative Sea Level Change: Past, Present and Future. Quaternary International 2:63-71.

Prewitt, Elton R.

1974 Preliminary Archeological Investigations in the Rio Grande Delta Area of Texas. Bulletin of the Texas Archeological Society 45: 55-65.

1981 Radiocarbon Dating. Appendix VIII in Cultural Resources Surveys and Assessments in Portions of Hidalgo and Willacy Counties, Texas, by D. William Day, Jane Laurens-Day, and Elton R. Prewitt, pp. 411415. Reports of Investigations No. 15. Prewitt and Associates, Inc., Austin.

Prewitt, Elton R., and Jeffrey G. Paine

1987 The Swan Lake Site (41AS16) on Copano Bay, Aransas County, Texas: Settlement, Subsistence, and Sea Level. Bulletin of the Texas Archeological Society 58:147-174.

Price, W. Armstrong

1958 Sedimentology and Quaternary Geomorphology of South Texas. Gulf Coast Association 
of Geological Societies Transactions 8:4175.

1963 Physicochemical and Environmental Factors in Clay Dune Genesis. Journal of Sedimentary Petrology 33(3):766-778.

Price, W. Armstrong, and Louis S. Kornicker

1961 Marine and Lagoonal Deposits in Clay Dunes, Gulf Coast, Texas. Journal of Sedimentary Petrology 31(2):245-255.

Quigg, J. Michael, Douglas K. Boyd, and Elton R. Prewitt

1989 An Archeological Survey of Proposed Drainage Ditch Realignments, Hidalgo County, Texas. Technical Reports No. 2. Prewitt and Associates, Inc., Austin.

Ricklis, Robert A.

1990 Changes in Prehistoric Hunter-Gatherer Economic Strategies and Mobility Patterns in the Southern Coastal Corridor. Department of Archeological Planning and Review, Texas Historical Commission, Austin.

Ricklis, Robert A., and Kim A. Cox

1991 Toward a Chronology of Adaptive Change During the Archaic of the Texas Coastal Bend Area. La Tierra 18(2):13-31.

Ruecking, Frederick, Jr.

1953 The Economic System of the Coahuiltecan Indians of Southern Texas and Northeastern New Mexico. The Texas Journal of Science 5(4):480-497.

1955 The Coahuiltecan Indians of Southern Texas and Northeastern Mexico. Unpublished Master's thesis, The University of Texas at Austin.

Salinas, Martin

1986 Historic Indian Populations of the Rio Grande Delta and Vicinity: An Approach to Definition of Basic Ethnic Units. Unpublished Master's thesis, Department of Anthropology, The University of Texas at Austin.

1990 Indians of the Rio Grande Delta: Their Role in the History of Southern Texas and Northeastern Mexico. The University of Texas Press, Austin.
Sayles, E. B.

1935 An Archaeological Survey of Texas. Medallion Papers 17. Gila Pueblo, Globe, Arizona.

Smith, B. N.

1976 Evolution of $\mathrm{C}_{4}$ Photosynthesis in Response to Changes in Carbon and Oxygen Concentrations in the Atmosphere Through Time. Biosystems 8:24-32.

Smith, B. N., and M. J. Robbins

1974 Evolution of $\mathrm{C}_{4}$ Photosynthesis: An Assessment Based on ${ }^{13} \mathrm{C} /{ }^{12} \mathrm{C}$ Ratios and Kranz Anatomy. In Proceedings of the Third International Congress on Photosynthesis, edited by M. Avron, pp. 1579-1587. Elsevier Scientific Publishing Co., Amsterdam.

Smith, Herman A.

1982 Burned Clay Objects in Southern Texas Archaeological Sites: A Reevaluation. $L a$ Tierra 9(4):34-36.

Stein, Julie K.

1992 Organic Matter in Archaeological Contexts. In Soils in Archaeology: Landscape Evolution and Human Occupation, edited by Vance T. Holliday, pp. 193-216. Smithsonian Institution Press, Washington, D.C.

Stright, Melanie J.

1990 Archaeological Sites on the North America Continental Shelf. In Archaeological Geology of North America, edited by Norman P. Lasca and Jack Donahue, pp. 439465. Centennial Special Volume 4. Geological Society of America, Boulder, Colorado.

Stuiver, M., and G. W. Pearson

1993 High-Precision Bidecadal Calibration of the Radiocarbon Time Scale, AD 1950-500 BC and 2500-6000 BC. Radiocarbon 35:1-23.

Suguio, Kenitiro, Louis Martin, and Jean-Marie Flexor 1992 Paleoshorelines and the Sambaquis of Brazil. In Paleoshorelines and Prehistory: An Investigation of Method, edited by Lucille Lewis Johnson and Melanie Stright, pp. 8399. CRC Press, Boca Raton. 
Teeri, J. A., and L. G. Stowe

1976 Climatic Patterns and the Distribution of $\mathrm{C}_{4}$ Grasses in North America. Oecologia 23:112.

Tieszen, L. L., and S. K. Imbamba

1980 Photosynthetic Systems, Carbon Isotope Discrimination and Herbivore Selectivity in Kenya. African Journal of Ecology 18:237242.

Tieszen, L. L., M. M. Senyimba, S. K. Imbamba, and J. H. Troughton

1979 The Distribution of $\mathrm{C}_{3}$ and $\mathrm{C}_{4}$ Grasses and Carbon Isotope Discrimination Along an Altitudinal and Moisture Gradient in Kenya. Oecologia 37:337-350.

Tooley, M. J.

1978 Sea Level Changes: North-West England During the Flandrian Stage. Clarendon Press, Oxford, England.

Turner, August J.

1982 Soil Survey of Willacy County, Texas. Soil Conservation Service, United States Department of Agriculture in cooperation with the Texas Agricultural Experiment Station.

U.S. Fish and Wildlife Service

1980 Department of the Interior Habitat Preservation Plan-Preservation of Areas of Important Fish and Wildlife Habitat: Cameron, Hidalgo, Starr, and Willacy Counties, Texas. U.S. Fish and Wildlife Service, Region 2, Albuquerque.

Visher, Glenn S.

1969 Grain Size Distributions and Depositional Processes. Journal of Sedimentary Petrology 39(3):1074-1106.

Vogel, J. C.

1980 Fractionation of the Carbon Isotopes During Photosynthesis. Springer, Berlin.
Waters, Michael R.

1992 Principles of Geoarchaeology: A North American Perspective. The University of Arizona Press, Tucson.

Weir, Frank A.

1956 Surface Artifacts from La Perdida, Starr County, Texas. Bulletin of the Texas Archeological Society 27:59-78.

Westgate, James E.

1987 A Preliminary Report on a Large Concentration of the Remains of the Giant Gopher Tortoise, Gopherus hexagonatus, in the Late Pleistocene Beaumont Formation of Willacy County, Texas. Appendix 4 in Cultural Resources Investigations Along Drainage Improvements, Hidalgo and Willacy Counties, Texas: 1986 Investigations, by Grant D. Hall, Michael B. Collins, and Elton R. Prewitt, pp. 199-219. Reports of Investigations No. 59. Prewitt and Associates, Inc., Austin.

White, W. A., T. R. Calnan, R. A. Morton, R. S. Kimble, T. G. Littleton, J. H. McGowen, and H. S. Nance

1989 Submerged Lands of Texas, Kingsville Area: Sediments, Geochemistry, Benthic Macroinvertebrates, and Associated Wetlands. Bureau of Economic Geology, The University of Texas at Austin.

Willey, Gordon R., and Philip Phillips

1958 Method and Theory in American Archaeology. University of Chicago Press, Chicago.

Winckler, S.

1976 Birds of Falcon, Starr County, Texas. In Rio Grande-Falcon Thorn Woodland, edited by D. Kennard, pp. 57-76. Natural Area Survey No. 13. Lyndon B. Johnson School of Public Affairs, The University of Texas at Austin. 
APPENDIX A: Geomorphic Profile Descriptions

Karl W. Kibler 

The geomorphic profiles are described and classified according to the procedures and criteria presented by Buol et al. (1980:21-43), Birkeland (1984), and Bettis (1984). The color (Munsell Soil Color Chart) and consistency (loose, very friable, friable, firm, very firm, and extremely firm) of a zone or sediment are recorded from a moist condition. Field definitions of texture consist of: (1) sand (loose, single-grained, moist cast will crumble); (2) sandy loam (mostly sand with enough silt and clay to be somewhat coherent, individual sand grains are visible, moist cast bears careful handling); (3) loam (even mixture of sand, silt, and clay, gritty yet fairly smooth and slightly plastic, moist cast handles freely); (4) silt loam (predominantly silt with small amounts of fine sand and clay, moist cast bears heavy handling but will not ribbon); (5) clay loam (predominately clay with small amounts of fine sand and silt, moist ribbon breaks easily, moist cast bears heavy handling, slightly plastic, kneaded heavy compact mass will not crumble); and (6) clay (very plastic and sticky when wet, flexible ribbon). The terms sandy clay, sandy clay loam, loamy sand, silty clay, silty clay loam, and silt are used when the texture of a zone could not be confidently placed into one of the above categories. The structure or soil aggregation of a zone or horizon is described by grade, size, and type. The grade is shown as weak, moderate, or strong. The size of the peds is shown as fine, medium, or coarse, depending on ped morphology or type. The type, referring to the shape of the peds, is identified as blocky (subangular and angular), platy, prismatic, columnar, or granular. Soil horizons not containing these characteristics are considered structureless. Final soil horizon classifications were made based on the terminology and criteria presented by Birkeland (1984) and Bettis (1984).

In the absence of soil formation, the sedimentary structures of a zone are presented. Types of sedimentary structures include, but are not limited to, planar laminations, graded beds, cross-stratifications, trough cross-stratifications, ripples, climbing ripples, and massive structures.

Mottles are described by color, abundance, contrast, and size. Abundance is shown as few $(<2 \%)$, common $(2-20 \%)$, and many $(>20 \%)$, while contrast is described as faint, distinct, or prominent. Size ranges are given as fine $(<0.5 \mathrm{~cm})$, medium $(0.5-1.5 \mathrm{~cm})$, or coarse $(>1.5 \mathrm{~cm})$. Terms pertaining to abundance are also used to describe the occurrence of inclusions or intrusive objects, such as gravels and charcoal. The lower boundary of each zone or horizon is described in terms of distinctiveness - very abrupt $(<0.1 \mathrm{~cm})$, abrupt $(0.1$ $2.5 \mathrm{~cm})$, clear $(2.5-6.4 \mathrm{~cm})$, gradual $(6.4-12.7 \mathrm{~cm})$, and diffused $(>12.7 \mathrm{~cm})$ — and topography — smooth, wavy, irregular, and broken. 
Zone

Depth (cm)

41 WY50

Backhoe Trench 2

1

$0-7$

2

3

$46-59$

4

$59-95$

5

$95-103$

6

$103-129$

7

$129-147$

8

$147-163$

9

$163-181$

10

$181-189$
Description

Grayish brown (10YR 5/2) sandy loam, friable, massive, many roots and rootlets, common humic materials, common insect burrows, abrupt smooth lower boundary, $\mathrm{Cu}$ horizon.

Dark gray (10YR 4/1) clay loam, firm, moderate medium subangular blocky structure, many humic materials, many roots and rootlets, common insect burrows, few $\mathrm{CaCO}_{3}$ flecks and filaments, abrupt smooth lower boundary, $2 \mathrm{Ab}$ horizon.

Grayish brown (2.5Y 5/2) clay, firm, moderate medium subangular blocky structure, many rootlets, common insect burrows, common humic materials, few $\mathrm{CaCO}_{3}$ flecks and filaments, abrupt smooth lower boundary, $2 \mathrm{Bb}$ horizon.

Grayish brown (2.5Y 5/2) clay loam, firm, massive, common rootlets, common humic materials, common insect burrows, common $\mathrm{CaCO}_{3}$ filaments that increase in number down-profile, abrupt smooth lower boundary, $2 \mathrm{Ck}$ horizon.

Light gray (2.5Y 7/2) clay loam, friable, massive, few insect burrows, thin $(3 \mathrm{~cm})$ discontinuous sandy lens at top of zone, few rootlets, abrupt smooth lower boundary, $2 \mathrm{Cu}$ horizon.

Light brownish gray $(2.5 \mathrm{Y} 6 / 2)$ clay, firm, weak medium subangular blocky structure, common rootlets, common humic materials in top $3 \mathrm{~cm}$ of zone, many insect burrows, few filled with organic debris and clay, very abrupt smooth lower boundary, 3AC horizon.

Grayish brown (2.5Y 5/2) sandy clay loam, firm, structureless, few planar laminations exist throughout the zone, many humic materials in top 5-8 cm of zone, few rootlets, common insect burrows, common thin $(<3 \mathrm{~mm})$ sandy lenses throughout the zone, abrupt smooth lower boundary, $4 \mathrm{AC}$ horizon.

Grayish brown (2.5Y 5/2) loam, firm, massive, few rootlets, common insect burrows, few humic materials, abrupt smooth lower boundary, $4 \mathrm{C}$ horizon.

Dark grayish brown $(2.5 \mathrm{Y} 4 / 2)$ clay loam, friable to firm, weak medium subangular blocky structure, many humic materials, common insect burrows, few incipient $\mathrm{CaCO}_{3}$ nodules, abrupt smooth lower boundary, $5 \mathrm{Ab}$ horizon.

Light brownish gray (10YR 6/2) to pale brown (10YR 6/3) clay loam, firm, weak medium subangular blocky structure, few humic materials, few rootlets, few insect burrows, lower boundary not observed, $5 \mathrm{C}$ horizon. 
Zone

Depth (cm)

Backhoe Trench 5

1

2

$8-36$

$3 \quad 36-68$

$4 \quad 68-112$

$5 \quad 112-128$

$6 \quad 128-140$

$7 \quad 140-155+$

\section{Backhoe Trench 6}

$1 \quad 0-5$

$2 \quad 5-37$

$3 \quad 37-65$
Description

Grayish brown (2.5Y 5/2) sandy loam, friable to firm, structureless, many roots and rootlets, many humic materials, common insect burrows, clear smooth lower boundary, AC horizon.

Grayish brown (2.5Y 5/2) clay loam, firm, moderate medium subangular blocky structure, common $\mathrm{CaCO}_{3}$ filaments, many roots and rootlets, common humic materials, common insect burrows, many filled with organic debris and brown (10YR 5/3) clay, clear smooth lower boundary, 2Abk horizon.

Light brownish gray $(2.5 \mathrm{Y} 6 / 2)$ clay, firm, weak fine subangular blocky structure, common roots and rootlets, common humic materials, few $\mathrm{CaCO}_{3}$ filaments, common insect burrows, few snail shell fragments, clear smooth lower boundary, $2 \mathrm{Bb}$ horizon.

Light brownish gray (10YR 6/2) sandy clay loam, firm, massive, common humic materials, common roots and rootlets, few insect burrows, thin $(2 \mathrm{~cm})$ discontinuous sandy lens at top of zone, common $\mathrm{CaCO}_{3}$ formed on roots and forming root casts, abrupt smooth lower boundary, $2 \mathrm{Ck}$ horizon.

Light brownish gray $(2.5 \mathrm{Y} 6 / 2)$ clay loam, firm, moderate medium subangular blocky structure, common to many humic materials, common rootlets few insect burrows, common sand-filled insect burrows and root casts, abrupt smooth lower boundary, $3 \mathrm{Ab}$ horizon.

Light gray $(2.5 \mathrm{Y} 7 / 2)$ to light brownish gray $(2.5 \mathrm{Y} 6 / 2)$ clay loam, firm, moderate to strong medium subangular blocky structure, many humic materials in the top $4 \mathrm{~cm}$ of zone, common rootlets, few insect burrows, common sand-filled voids, sand-covered ped faces, abrupt smooth lower boundary, 4AC horizon.

Light brownish gray $(2.5 \mathrm{Y} 6 / 2)$ clay loam, firm, massive, few roots and rootlets, few humic materials, few insect burrows, lower boundary not observed, $4 \mathrm{C}$ horizon.

Dark grayish brown (2.5Y 4/2) sandy clay loam, friable to firm, structureless, many roots and rootlets, common humic materials, common insect burrows, abrupt smooth lower boundary, AC horizon.

Grayish brown (10YR 5/2) clay loam, firm, moderate medium subangular blocky structure, many roots and rootlets, common humic materials, common insect burrows and burrow casts, clear smooth lower boundary, $2 \mathrm{Ab}$ horizon.

Grayish brown (2.5Y 5/2) sandy clay loam, firm, massive, common rootlets, common insect burrows and burrow casts, common humic materials, few $\mathrm{CaCO}_{3}$ filaments in lower half of zone, thin $(1-2 \mathrm{~cm})$ discontinuous sandy lens at top of zone, abrupt smooth lower boundary, $2 \mathrm{C}$ horizon. 


$\begin{array}{cc}\text { Zone } & \text { Depth (cm) } \\ 4 & 65-72 \\ 5 & 72-87 \\ 6 & 87-92 \\ & \\ 7 & 92-123 \\ 7 & \\ 8 & 123-140+\end{array}$

$\underline{\text { Backhoe Trench } 7}$

$1 \quad 0-8$

2

8-39

3

$39-45$

4

$45-68$

$5 \quad 68-88$

\section{Description}

Grayish brown (2.5Y 5/2) clay loam, friable, massive, common insect burrows and burrow casts, few $\mathrm{CaCO}_{3}$ flecks and filaments, common rootlets, few humic materials, abrupt smooth lower boundary, $2 \mathrm{C} 2$ horizon.

Grayish brown (2.5Y 5/2) clay loam, firm, moderate medium subangular blocky structure, common insect burrows, common humic materials, common roots and rootlets, few $\mathrm{CaCO}_{3}$ filaments, abrupt smooth lower boundary, $3 \mathrm{Ab}$ horizon.

Dark grayish brown (2.5Y 4/2) clay loam to loam, friable to firm, structureless, many humic materials, common rootlets, few $\mathrm{CaCO}_{3}$ filaments, common insect burrows, few pieces of charcoal, abrupt smooth lower boundary, 4AC horizon.

Light brownish gray $(2.5 \mathrm{Y} 6 / 2)$ to grayish brown $(2.5 \mathrm{Y} 5 / 2)$ clay loam, friable to firm, moderate medium subangular blocky structure, common rootlets, common insect burrows and burrow casts, few humic materials, thin $(2 \mathrm{~cm})$ discontinuous sandy lens across bottom of zone, abrupt smooth lower boundary, $4 \mathrm{C}$ horizon.

Light brownish gray (2.5Y 6/2) clay loam, firm, structureless, many humic materials in top $3 \mathrm{~cm}$ of zone, common rootlets, common insect burrows, few small incipient $\mathrm{CaCO}_{3}$ nodules, lower boundary not observed, $5 \mathrm{AC}$ horizon.

Light brownish gray (2.5Y 6/2) sandy loam, friable, structureless, many rootlets, many humic materials, many insect burrows, clear smooth lower boundary, AC horizon.

Grayish brown (2.5Y 5/2) clay loam, friable to firm, weak fine subangular blocky structure, common humic materials, many roots and rootlets, few vertical drying cracks, common insect burrows, abrupt smooth lower boundary, $2 \mathrm{Ab}$ horizon.

Dark gray (10YR 4/1) clay loam, friable to firm, structureless, many humic materials, common rootlets, common insect burrows, abrupt smooth lower boundary, 2AC horizon.

Grayish brown (10YR 5/2) clay, firm, moderate fine subangular blocky structure, many insect burrows and burrow casts, common rootlets, few sand-filled insect burrows, few $\mathrm{CaCO}_{3}$ filaments, common humic materials, clear smooth lower boundary, $3 \mathrm{Ab}$ horizon.

Grayish brown (2.5Y 5/2) clay loam, firm, structureless, many humic materials in top $3 \mathrm{~cm}$ of zone, common insect burrows, common rootlets, clear smooth lower boundary, 3AC horizon. 
Zone

Depth (cm)

6

$88-108$

7

$108-132$

8

$132-152+$

Backhoe Trench 8

1

0-6

2

$6-21$

3

$21-45$

4

$45-71$

5

$71-81$

6

$81-92$

7

$92-114$

8

\section{Description}

Grayish brown (2.5Y 5/2) clay loam, firm, moderate medium angular blocky structure, many humic materials in top $5 \mathrm{~cm}$ of zone, common rootlets, common insect burrows, few pieces of charcoal, thin $(4 \mathrm{~cm})$ sandy lens interbedded with thin mud laminae at bottom of zone that pinches out laterally, clear smooth lower boundary, 4AC horizon.

Grayish brown (2.5Y 5/2) clay loam, firm, moderate medium subangular blocky structure, common humic materials in top $5 \mathrm{~cm}$ of zone, common insect burrows, abrupt smooth lower boundary, 5AC horizon.

Light brownish gray $(2.5 \mathrm{Y} 6 / 2)$ to grayish brown $(2.5 \mathrm{Y} 5 / 2)$ loam, firm, massive, common $\mathrm{CaCO}_{3}$ flecks, few humic materials, few insect burrows, lower boundary not observed, $5 \mathrm{Ck}$ horizon.

Grayish brown (2.5Y 5/2) sandy clay loam, friable, massive, many roots and rootlets, common humic materials, abrupt smooth lower boundary, $\mathrm{Cu}$ horizon.

Dark grayish brown (2.5Y 4/2) clay loam, friable to firm, moderate medium subangular blocky structure, many roots and rootlets, many humic materials, common insect burrows, few snail shell fragments, clear smooth lower boundary, 2Ab horizon.

Grayish brown (2.5Y 5/2) clay loam, firm, structureless, many insect burrows and burrow casts, many rootlets, common humic materials, abrupt smooth lower boundary, $2 \mathrm{AC}$ horizon.

Grayish brown (2.5Y 5/2) clay loam, firm, structureless, many humic materials in top $5 \mathrm{~cm}$ of zone, few $\mathrm{CaCO}_{3}$ filaments, common insect burrows and burrow casts, three thin $(1 \mathrm{~cm})$ light brownish gray $(10 \mathrm{YR} 6 / 2)$ sandy lenses at bottom of zone, abrupt wavy lower boundary, $3 \mathrm{AC}$ horizon.

Dark gray (10YR 4/1) clay loam, firm, structureless, few $\mathrm{CaCO}_{3}$ filaments, common insect burrows, many humic materials, abrupt wavy lower boundary, $4 \mathrm{AC}$ horizon.

Grayish brown (2.5Y 5/2) clay loam, firm, moderate fine subangular blocky structure, few $\mathrm{CaCO}_{3}$ filaments, common humic materials, common insect burrows, few filled with sand, abrupt smooth lower boundary, 5AC horizon.

Grayish brown (2.5Y 5/2) clay loam, firm, moderate medium subangular blocky structure, few $\mathrm{CaCO}_{3}$ filaments, few brown (10YR 5/3) sand-filled voids, common insect burrows, many humic materials in top $3 \mathrm{~cm}$ of zone, common rootlets, abrupt smooth lower boundary, $6 \mathrm{AC}$ horizon.

Grayish brown (2.5Y 5/2) sandy clay loam, friable to firm, massive, common insect burrows, common soft $\mathrm{CaCO}_{3}$ nodules and filaments, few rootlets, few humic materials, abrupt smooth lower boundary, $6 \mathrm{Ck}$ horizon. 


\section{Zone} Depth (cm)

$9 \quad 135-153$

$10 \quad 153-170+$

\section{Backhoe Trench 9}

$1 \quad 0-6$

$2 \quad 6-36$

$3 \quad 36-61$

$4 \quad 61-98$

$5 \quad 98-121$

$6 \quad 121-137$

$7 \quad 137-146$

$8 \quad 146-155+$

\section{Description}

Grayish brown (2.5Y 5/2) to dark grayish brown (2.5Y 4/2) sandy clay loam, firm, structureless, many humic materials in top $4 \mathrm{~cm}$ of zone, common soft $\mathrm{CaCO}_{3}$ nodules and filaments, common incipient $\mathrm{CaCO}_{3}$ nodules, common insect burrows, clear smooth lower boundary, 7ACk horizon.

Grayish brown (2.5Y 5/2) sandy loam, friable to firm, massive, few soft $\mathrm{CaCO}_{3}$ nodules, common insect burrows, common humic materials in upper half of observable zone, lower boundary not observed, 7C horizon.

Dark grayish brown (2.5Y 4/2) sandy loam, firm, structureless, many roots and rootlets, common insect burrows, common humic materials, abrupt smooth lower boundary, AC horizon.

Grayish brown (2.5Y 5/2) clay loam, friable, moderate medium subangular blocky structure, common insect burrows, common humic materials, common roots and rootlets, few soft $\mathrm{CaCO}_{3}$ nodules, few insect burrows filled with organic debris, abrupt smooth lower boundary, $2 \mathrm{Ab}$ horizon.

Grayish brown (2.5Y 5/2) clay loam, firm, structureless, common to many humic materials in top $3 \mathrm{~cm}$ of zone, common rootlets, common insect burrows, few filled with brown (10YR 5/3) clay, few pieces of charoal, abrupt smooth lower boundary, 2AC horizon.

Light brownish gray (2.5Y 6/2) clay loam, firm, moderate fine subangular blocky structure, few $\mathrm{CaCO}_{3}$ filaments, common insect burrows, common humic materials in top $2 \mathrm{~cm}$ of zone, common rootlets, a few insect burrows filled with organic debris and brown (10YR 5/3) clay, abrupt smooth lower boundary, 3AC horizon.

Grayish brown (2.5Y 5/2) clay loam, firm, weak fine angular blocky structure, many humic materials in top $2 \mathrm{~cm}$ of zone, thin $(2 \mathrm{~cm})$ discontinuous sandy lens at $101 \mathrm{~cm}$ below surface, common rootlets, common insect burrows, few incipient $\mathrm{CaCO}_{3}$ nodules, abrupt smooth to wavy lower boundary, 4AC horizon.

Grayish brown (2.5Y 5/2) sandy clay loam, firm, structureless, few planar laminations in top $5 \mathrm{~cm}$ of zone, many humic materials in top $4 \mathrm{~cm}$ of zone, few incipient $\mathrm{CaCO}_{3}$ nodules, few rootlets, abrupt smooth lower boundary, $5 \mathrm{AC}$ horizon.

Grayish brown (2.5Y 5/2) clay loam, friable to firm, massive, few humic materials, few rootlets, few insect burrows, abrupt smooth lower boundary, $5 \mathrm{C}$ horizon.

Gray (10YR 5/1) to dark gray (10YR 4/1) clay loam, firm, structureless, common to many humic materials, lower boundary not observed, 6AC horizon. 
Zone

Depth $(\mathbf{c m})$

Backhoe Trench 11

Locality $11 a$

1

$0-10$

2

$10-23$

3

$23-32$

4

$32-44$

5

$44-61$

6

$61-78$

7

$78-106$

8

106-116

9

$116-124$

$10 \quad 124-131$

\section{Description}

Grayish brown (2.5Y 5/2) friable to firm fine sandy loam consisting of fine thin $(<2 \mathrm{~mm})$ small ripples and planar laminations, common humic materials, many roots and rootlets, common insect burrows, few thin $(1 \mathrm{~cm})$ discontinuous bands of organic-rich sediments, abrupt wavy lower boundary, $\mathrm{Cu}$ horizon.

Light brownish gray $(2.5 \mathrm{Y} 6 / 2)$ clay loam, firm, moderate fine subangular blocky structure, common roots and rootlets, common insect burrows, few soft $\mathrm{CaCO}_{3}$ nodules, common humic materials, abrupt smooth lower boundary, $\mathrm{C}$ horizon.

Dark gray (10YR 4/1) clay loam, firm, structureless, common soft $\mathrm{CaCO}_{3}$ nodules, many humic materials, common roots and rootlets, common insect burrows, few pieces of charcoal, clear smooth lower boundary, 2Abk horizon.

Light brownish gray (2.5 Y 6/2) clay loam, firm, moderate fine subangular blocky structure, few humic materials, many soft $\mathrm{CaCO}_{3}$ nodules, few rootlets, common insect burrows, abrupt smooth lower boundary, 2Bbk horizon.

Grayish brown (2.5Y 5/2) clay loam, firm, structureless, thin $(1 \mathrm{~cm})$ organicrich lens across top of zone, many soft $\mathrm{CaCO}_{3}$ nodules, common humic materials, common insect burrows, few snail shell fragments, few rootlets, abrupt smooth lower boundary, $3 \mathrm{ACk}$ horizon.

Light brownish gray (10YR 6/2) clay, firm, structureless, many soft $\mathrm{CaCO}_{3}$ nodules, common humic materials, thin $(1 \mathrm{~cm})$ organic-rich lens at top of zone, few rootlets, common insect burrows, gradual smooth lower boundary, 4ACk horizon.

Grayish brown (2.5Y 5/2) clay, firm, massive, common soft $\mathrm{CaCO}_{3}$ nodules, common insect burrows, few are sand filled, common humic materials, abrupt smooth lower boundary, $4 \mathrm{Ck}$ horizon.

Light brownish gray (10YR 6/2) clay, friable to firm, massive, common soft $\mathrm{CaCO}_{3}$ nodules and filaments, common insect burrows, common humic materials, very abrupt smooth lower boundary, $4 \mathrm{Ck} 2$ horizon.

Dark gray (10YR 4/1) clay loam, friable, structureless, common soft $\mathrm{CaCO}_{3}$ nodules and filaments, many humic materials, abrupt smooth lower boundary, 5ACk horizon.

Grayish brown (2.5Y 5/2) sandy clay loam, friable to firm, massive, common soft $\mathrm{CaCO}_{3}$ nodules, abrupt smooth lower boundary, $5 \mathrm{Ck}$ horizon. 
Zone

11 131-138+

Locality $11 b$

$1 \quad 0-10$

2

10-24

3

24-34

4

34-54

5

54-68

6

68-83

7

$83-90$

$890-104$

9 104-122+

\section{Description}

Dark gray (10YR 4/1) sandy clay loam, friable to firm, structureless, many humic materials, common $\mathrm{CaCO}_{3}$ nodules and filaments, lower boundary not observed, 6ACk horizon.

Grayish brown (2.5Y 5/2) friable fine sandy clay loam consisting of thin $(<2 \mathrm{~mm})$ ripples and swales and a few thin muddy lenses, many roots and rootlets, many insect burrows, common humic materials, abrupt wavy lower boundary, $\mathrm{Cu}$ horizon.

Grayish brown (10YR 5/2) sandy clay loam, firm, massive, many soft $\mathrm{CaCO}_{3}$ nodules, many roots and rootlets, common insect burrows, common humic materials, abrupt smooth lower boundary, Ck horizon.

Grayish brown (2.5Y 5/2) sandy clay loam, firm, structureless, common soft $\mathrm{CaCO}_{3}$ nodules, common humic materials, common insect burrows, common rootlets, clear smooth lower boundary, $2 \mathrm{ACk}$ horizon.

Dark grayish brown (10YR 4/2) sandy clay loam, firm, structureless, thin $(2 \mathrm{~cm})$ organic-rich lens at $44 \mathrm{~cm}$ below surface, thin $(3 \mathrm{~cm})$ fine sandy lens (10YR 5/3) across the bottom of the zone, common soft $\mathrm{CaCO}_{3}$ nodules, few roots and rootlets, common insect burrows, common humic materials, clear smooth lower boundary, 3ACk horizon.

Light brownish gray (10YR 6/2) to grayish brown (2.5Y 5/2) clay loam, firm, massive, common soft $\mathrm{CaCO}_{3}$ nodules, common insect burrows, few rootlets, few humic materials, abrupt smooth lower boundary, $3 \mathrm{Ck}$ horizon.

Grayish brown (2.5Y 5/2) clay loam, firm, moderate fine subangular blocky structure, thin $(2 \mathrm{~cm})$ organic-rich lens at top of zone, common soft $\mathrm{CaCO}_{3}$ nodules, few insect burrows, few snail shell fragments, common humic materials, common sand-filled insect burrows and root casts, abrupt smooth lower boundary, $4 \mathrm{ACk}$ horizon.

Dark gray (10YR 4/1) clay loam, friable to firm, moderate fine subangular blocky structure, few soft $\mathrm{CaCO}_{3}$ nodules, many humic materials, few insect burrows, abrupt smooth lower boundary, $5 \mathrm{Ab}$ horizon.

Grayish brown (2.5Y 5/2) clay, firm, massive, few soft $\mathrm{CaCO}_{3}$ nodules, few insect burrows, abrupt smooth lower boundary, $5 \mathrm{C}$ horizon.

Dark gray (10YR 4/1) clay loam, firm, structureless, many humic materials, few soft $\mathrm{CaCO}_{3}$ nodules and filaments, common incipient $\mathrm{CaCO}_{3}$ nodules, lower boundary not observed, 6AC horizon. 
Zone Depth $(\mathrm{cm})$

Locality $11 c$

1

$0-7$

2

$17-26$

3

$26-44$

4

$44-55$

5

$55-62$

6

$62-75$

7

$75-124+$

\section{Description}

Grayish brown (2.5Y 5/2) friable to firm fine sandy loam consisting of small ripples and swales, common thin $(<3 \mathrm{~mm})$ muddy lenses, many humic materials, many insect burrows, many roots and rootlets, abrupt wavy lower boundary, $\mathrm{Cu}$ horizon.

Clay loam consisting of interbedded thin (1-10 mm) grayish brown $(2.5 \mathrm{Y}$ $5 / 2$ ) mud laminae and ripples and grayish brown (10YR 5/2) to brown (10YR $5 / 3$ ) sand laminae and ripples, sand percentages increase and coarsen down profile and basinward, few soft $\mathrm{CaCO}_{3}$ nodules, common rootlets, many humic materials, common insect burrows, very abrupt wavy lower boundary, $2 \mathrm{Cu}$ horizon.

Grayish brown (2.5Y 5/2) clay, firm, massive, common to many soft $\mathrm{CaCO}_{3}$ nodules, few charcoal flecks, few humic materials, common rootlets, few insect burrows, few are sand filled, very abrupt wavy lower boundary, $3 \mathrm{Ck}$ horizon.

Dark grayish brown (2.5Y 4/2) clay loam, firm, weak fine subangular blocky structure, many soft $\mathrm{CaCO}_{3}$ nodules, few rootlets, common humic materials, few insect burrows, abrupt smooth lower boundary, 4Abk horizon.

Light brownish gray (10YR 6/2) clay, firm, massive, common soft $\mathrm{CaCO}_{3}$ nodules, common incipient $\mathrm{CaCO}_{3}$ nodules, few rootlets, few insect burrows, few to common humic materials, abrupt smooth lower boundary, $4 \mathrm{Ck}$ horizon.

Dark grayish brown (2.5Y 4/2) clay loam, firm, structureless, common soft $\mathrm{CaCO}_{3}$ nodules, common incipient $\mathrm{CaCO}_{3}$ nodules, many humic materials, few insect burrows, few rootlets, abrupt smooth lower boundary, 5Abk horizon.

Brown (7.5YR 5/2) clay loam, firm, moderate medium angular blocky structure, few $\mathrm{CaCO}_{3}$ nodules, common krotovina filled with mud (10YR $5 / 1$ ), common humic materials in upper $10 \mathrm{~cm}$ of zone, common gypsum crystals, few vesicular sand patterns, lower boundary not observed, $6 \mathrm{C}$ horizon.

\section{WY 60}

Backhoe Trench 8

$1 \quad 0-35$

Grayish brown (2.5Y 5/2) silty clay loam, firm, moderate coarse angular blocky structure, few very thin sandy laminae in lower half of zone, common roots and rootlets, common humic materials, common insect burrows, abrupt smooth lower boundary, A horizon. 
Zone

2

Depth (cm)

$35-45$

3

$45-54$

4

$54-58$

5

$58-73$

6

$73-81$

7

81-109

$8 \quad 109-144$

9

$144-152+$

\section{Backhoe Trench 9}

$1 \quad 0-9$

$2 \quad 9-39$

$3 \quad 39-50$

\section{Description}

Interbedded small ripples and few planar laminations of brown (10YR 5/3) sand and very dark grayish brown (10YR 3/2) mud, common roots and rootlets, common insect burrows, common humic materials, very abrupt smooth to wavy lower boundary, $\mathrm{Cu}$ horizon.

Dark gray (10YR 4/1) silty clay loam, friable, moderate medium angular blocky structure, many distinct fine mottles (10YR 5/3), common rootlets, common $\mathrm{CaCO}_{3}$ filaments, few insect burrows, few charcoal flecks, common humic materials, clear smooth lower boundary, 2Abk horizon.

Grayish brown (2.5Y 5/2) clay loam, friable, weak fine angular blocky structure, many brown (10YR 5/3) distinct fine mottles, common rootlets, common insect burrows, common humic materials, clear smooth lower boundary, $2 \mathrm{AC}$ horizon.

Gray to dark gray (10YR 5/1 to 4/1) clay loam, firm, moderate medium subangular blocky structure, few rootlets, few insect burrows, few snail shell fragments, few charcoal chunks, abrupt smooth lower boundary, $2 \mathrm{C}$ horizon.

Grayish brown (2.5Y 5/2) clay loam to loam, firm, massive, common dark gray (10YR 4/1) distinct medium mottles, few rootlets, few humic materials, abrupt smooth lower boundary, $2 \mathrm{C} 2$ horizon.

Dark gray (10YR 4/1) clay loam, firm, weak medium subangular blocky structure, common grayish brown ( $2.5 \mathrm{Y} 5 / 2)$ distinct fine mottles, few $\mathrm{CaCO}_{3}$ filaments, few rootlets, common humic materials, few insect burrows, abrupt wavy lower boundary, 3Ab horizon.

Grayish brown (2.5Y 5/2) silty clay, firm, massive, few $\mathrm{CaCO}_{3}$ filaments, few rootlets, abrupt smooth lower boundary, $3 \mathrm{C}$ horizon.

Dark gray (10YR 4/1) silty clay loam, firm, weak fine subangular blocky structure, few $\mathrm{CaCO}_{3}$ filaments, few rootlets, lower boundary not observed, $4 \mathrm{Ab}$ horizon.

Grayish brown (2.5Y 5/2) clay loam, firm, weak fine subangular blocky structure, many rootlets, common insect burrows, many humic materials, clear smooth to wavy lower boundary, A horizon.

Grayish brown (2.5Y 5/2) clay loam, firm, strong medium subangular blocky structure, few $\mathrm{CaCO}_{3}$ filaments, many rootlets, many insect burrows, many humic materials, clear smooth lower boundary, $2 \mathrm{Ab}$ horizon.

Grayish brown (10YR 5/2) silty clay loam, firm, moderate fine angular blocky structure, few soft $\mathrm{CaCO}_{3}$ nodules, many rootlets, common insect burrows, common humic materials, clear smooth lower boundary, $2 \mathrm{~A} 2 \mathrm{bk}$ horizon. 


$\begin{array}{cr}\text { Zone } & \text { Depth (cm) } \\ 4 & 50-124 \\ 5 & 124-151 \\ & \\ 6 & 151-182+\end{array}$

Backhoe Trench 10

$1 \quad 0-7$

2 $7-31$

3 $31-61$

4 $61-75$

5 $75-84$

6 84-91

$7 \quad 91-102$

\section{Description}

Grayish brown (10YR 5/2) clay loam, firm, massive, common soft $\mathrm{CaCO}_{3}$ nodules, common rootlets, common insect burrows, $\mathrm{CaCO}_{3}$ formed around rootlets and forming root casts, few humic materials, clear smooth lower boundary, 2Ck horizon.

Pale brown (10YR 6/3) silt loam, firm, massive, common soft $\mathrm{CaCO}_{3}$ nodules, few to common humic materials, abrupt smooth lower boundary, $2 \mathrm{Ck} 2$ horizon.

Yellowish brown (10YR 5/4) silty clay loam, friable, massive, few humic materials, many soft $\mathrm{CaCO}_{3}$ nodules, lower boundary not observed, $3 \mathrm{Ck}$ horizon.

Dark grayish brown $(2.5 \mathrm{Y} 4 / 2)$ loam, firm, structureless, few very thin $(<5 \mathrm{~mm})$ fine sand to silt laminae, many roots and rootlets, common insect burrows, many humic materials, clear wavy lower boundary, AC horizon.

Dark grayish brown (2.5Y 4/2) clay loam, firm, moderate fine subangular blocky structure, many roots and rootlets, many insect burrows, many humic materials, common $\mathrm{CaCO}_{3}$ filaments filling root voids, few snail shell fragments, clear wavy lower boundary, $2 \mathrm{Ab}$ horizon.

Grayish brown (2.5Y 5/2) clay loam, firm, moderate fine subangular blocky structure, many rootlets, many humic materials, many insect burrows, common $\mathrm{CaCO}_{3}$ filaments and soft nodules, commmon sand-filled cracks, voids, and insect burrows, two dark organic-rich lenses at 32 and $47 \mathrm{~cm}$, thin sand lens at $48 \mathrm{~cm}$, abrupt smooth lower boundary, $2 \mathrm{AC}$ horizon.

Grayish brown (10YR 5/2) silty clay loam, friable, structureless, few insect burrows, few soft $\mathrm{CaCO}_{3}$ nodules, few rootlets, many humic materials, thin $(1 \mathrm{~cm})$ organic-rich lens at top of zone, abrupt smooth lower boundary, 3AC horizon.

Dark grayish brown $(2.5 \mathrm{Y} 4 / 2)$ silty clay loam, friable, moderate fine subangular blocky structure, few rootlets, few insect burrows, common humic materials, few soft $\mathrm{CaCO}_{3}$ nodules, thin $(<1 \mathrm{~cm})$ organic-rich lens at top of zone, abrupt wavy lower boundary, 4AC horizon.

Grayish brown (10YR 5/2) clay loam, firm, structureless, few brown to dark brown (10YR 4/3) prominent medium sandy silt mottles, few rootlets, few insect burrows, common humic materials, few soft $\mathrm{CaCO}_{3}$ nodules, abrupt smooth lower boundary, 5AC horizon.

Dark grayish brown (2.5Y 4/2) clay loam, firm, structureless, few rootlets, few insect burrows, common soft $\mathrm{CaCO}_{3}$ nodules, thin $(1 \mathrm{~cm})$ organic-rich lens at top of zone, abrupt smooth lower boundary, $6 \mathrm{ACk}$ horizon. 
Zone

8

9

10

$126-129$

11

$129-141$

$12 \quad 141-152$

$13 \quad 152-169+$

\section{Backhoe Trench 11}

$1 \quad 0-2$

$2 \quad 2-25$

$3 \quad 25-36$

$4 \quad 36-58$

$5 \quad 58-69$

\section{Description}

Grayish brown (10YR 5/2) silty clay, friable, structureless, common humic materials, few rootlets, few $\mathrm{CaCO}_{3}$ nodules, common $\mathrm{CaCO}_{3}$ filling old root voids, two thin $(1 \mathrm{~cm})$ organic-rich lens at 102 and $109 \mathrm{~cm}$, abrupt wavy lower boundary, 7ACk horizon.

Brown (10YR 5/3) silty clay, friable, structureless, few soft $\mathrm{CaCO}_{3}$ nodules, few rootlets, many humic materials, thin $(2 \mathrm{~cm})$ organic-rich lens at top of zone, abrupt smooth lower boundary, $8 \mathrm{AC}$ horizon.

Grayish brown to brown (10YR $5 / 2$ to $5 / 3$ ) silty clay, friable, massive, few faint fine mottles (10YR 5/3), few soft $\mathrm{CaCO}_{3}$ nodules, common humic materials, clear smooth lower boundary, $8 \mathrm{C}$ horizon.

Dark grayish brown (10YR 4/2) silty clay, friable, structureless, many humic materials, few soft $\mathrm{CaCO}_{3}$ nodules, abrupt smooth lower boundary, $9 \mathrm{AC}$ horizon.

Grayish brown (10YR 5/2) silty clay, friable, massive, common humic materials, common soft $\mathrm{CaCO}_{3}$ nodules, clear smooth lower boundary, $9 \mathrm{Ck}$ horizon.

Brown to dark brown (10YR 4/3) silty clay, friable, massive, common soft $\mathrm{CaCO}_{3}$ nodules, few humic materials, lower boundary not observed, $9 \mathrm{Ck} 2$ horizon.

Grayish brown (2.5Y 5/2) friable silty clay loam consisting of fine thin sand and silt laminae, many roots and rootlets, many insect burrows, common humic materials, clear smooth lower boundary, Cu horizon.

Grayish brown (10YR 5/2) silty clay loam, friable, moderate fine angular blocky structure, many rootlets, many insect burrows, many humic materials, few sand-filled voids and cracks, clear wavy lower boundary, 2Ab horizon.

Dark grayish brown (2.5Y 4/2) clay loam, firm, moderate fine angular blocky structure, few yellowish brown (10YR 5/4) prominent medium mottles, many roots and rootlets, common insect burrows, many humic materials, few $\mathrm{CaCO}_{3}$ filaments, thin $(<1 \mathrm{~cm})$ organic-rich lens at top of zone, clear smooth lower boundary, $2 \mathrm{~A} 2 \mathrm{~b}$ horizon.

Grayish brown (2.5Y 5/2) clay loam, firm, moderate medium subangular blocky structure, few yellowish brown (10YR 5/4) prominent medium mottles, many rootlets, common insect burrows, few charcoal flecks, few soft $\mathrm{CaCO}_{3}$ nodules, abrupt smooth lower boundary, $2 \mathrm{Bb}$ horizon.

Dark gray (10YR 4/1) silty clay loam, friable to firm, moderate fine subangular blocky structure, many humic materials, common rootlets, common insect burrows, few $\mathrm{CaCO}_{3}$ flecks, abrupt smooth lower boundary, $3 \mathrm{Ab}$ horizon. 


$\begin{array}{cc}\text { Zone } & \text { Depth (cm) } \\ 6 & 69-94 \\ 7 & 94-102 \\ & \\ 8 & 102-108 \\ 9 & 108-138\end{array}$

$10 \quad 138-154$

$11 \quad 154-163$

$12 \quad 163-185$

$13 \quad 185-201+$

\section{Backhoe Trench 12}

$1 \quad 0-30$

$2 \quad 30-38$

\section{Description}

Dark grayish brown (10YR 4/2) silty clay loam, firm, structureless, common humic materials, common insect burrows, common $\mathrm{CaCO}_{3}$ filaments and soft nodules, $\mathrm{CaCO}_{3}$-filled root voids and insect burrows, few sand-filled insect burrows, abrupt smooth lower boundary, $3 \mathrm{ACk}$ horizon.

Grayish brown (2.5Y 5/2) silty clay, firm, massive, few rootlets, few sand-filled insect burrows, common soft $\mathrm{CaCO}_{3}$ nodules, thin $(2 \mathrm{~cm})$ organic-rich lens at $95 \mathrm{~cm}$, abrupt smooth to wavy lower boundary, $3 \mathrm{Ck}$ horizon.

Dark grayish brown (2.5Y 4/2) clay loam, firm, structureless, few insect burrows, common humic materials in upper half of zone, common soft $\mathrm{CaCO}_{3}$ nodules, few rootlets, clear smooth lower boundary, $4 \mathrm{ACk}$ horizon.

Dark grayish brown (2.5Y 4/2) silty clay, friable, massive, few distinct medium mottles (10YR $5 / 2$ to $5 / 3$ ), common humic materials, few insect burrows filled with sand, $\mathrm{CaCO}_{3}$, or organic debris, common $\mathrm{CaCO}_{3}$ filaments and nodules, abrupt smooth lower boundary, $4 \mathrm{Ck}$ horizon.

Grayish brown (2.5Y 5/2) silty clay, firm, structureless, many humic materials in upper half of zone, few soft $\mathrm{CaCO}_{3}$ nodules, few rootlets, thin $(2 \mathrm{~cm})$ organic-rich lens at top of zone, very abrupt smooth lower boundary, $5 \mathrm{AC}$ horizon.

Grayish brown (2.5Y 5/2) clay loam, firm, structureless, few distinct coarse silty sand lenses (10YR $5 / 2$ to $5 / 3$ ), few insect burrows, many humic materials, common $\mathrm{CaCO}_{3}$ flecks, thin $(2 \mathrm{~cm})$ organic-rich lens at top of zone, abrupt smooth lower boundary, 6AC horizon.

Grayish brown (2.5Y 5/2) silty clay, friable to firm, structureless, common distinct coarse mottles (10YR 4/3) in upper half of zone, many humic materials in upper half of zone, few soft $\mathrm{CaCO}_{3}$ nodules, common organicstained sediments, abrupt smooth lower boundary, 7AC horizon.

Dark grayish brown (10YR 4/2) silty clay, friable to firm, structureless, few $\mathrm{CaCO}_{3}$ nodules, many humic materials in upper half of zone, lower boundary not observed, 8AC horizon.

Grayish brown (2.5Y 5/2) silty clay, friable, structureless with few thin $(<1 \mathrm{~cm})$ lenticular planar-laminated sand bodies, many roots and rootlets, many insect burrows, common humic materials, abrupt smooth lower boundary, AC horizon.

Dark gray (10YR 4/1) silty clay loam, friable, massive, many roots and rootlets, many insect burrows, common humic materials, common snail shell fragments, abrupt smooth lower boundary, $\mathrm{C}$ horizon. 
Zone

3

Depth (cm)

$38-47$

4

$47-57$

$5 \quad 57-88$

6

88-113

7

113-122

$8 \quad 122-128$

9

128-156+

\section{Backhoe Trench 13}

$1 \quad 0-22$

2

3

\section{Description}

Very dark gray (10YR 3/1) clay loam, friable to firm, moderate fine angular blocky structure, common roots and rootlets, many insect burrows, many humic materials, common $\mathrm{CaCO}_{3}$ filaments, common silty sand-filled voids and insect burrows, abrupt smooth lower boundary, 2Abk horizon.

Dark grayish brown (2.5Y 4/2) silty clay loam, friable, structureless, many rootlets, many insect burrows, many humic materials, many sand- and organic debris-filled voids, clear smooth lower boundary, 2AC horizon.

Dark gray (10YR 4/1) grading down-profile to grayish brown (2.5Y 5/2) silty clay, firm, massive, common rootlets, common insect burrows, many humic materials, common $\mathrm{CaCO}_{3}$ filaments that fill root voids, abrupt smooth lower boundary, $2 \mathrm{Ck}$ horizon.

Grayish brown (2.5Y 5/2) silty clay, friable to firm, structureless, common rootlets, common insect burrows, few $\mathrm{CaCO}_{3}$ filaments, many humic materials in upper one-third of zone, abrupt smooth lower boundary, 3AC horizon.

Dark grayish brown (2.5Y 4/2) clay loam, friable to firm, structureless, many humic materials, common rootlets, common insect burrows, few $\mathrm{CaCO}_{3}$ filaments, abrupt smooth lower boundary, 4AC horizon.

Brown (10YR 5/3) clay loam, firm, massive, common rootlets, few humic materials, few insect burrows, common $\mathrm{CaCO}_{3}$ filaments and incipient nodules, abrupt smooth lower boundary, $4 \mathrm{Ck}$ horizon.

Dark grayish brown (10YR 4/2) to dark brown (10YR 4/3) clay loam, firm, structureless, few rootlets, common insect burrows, many humic materials, common $\mathrm{CaCO}_{3}$ filaments and nodules, thin $(5 \mathrm{~cm})$ organic-rich lens at top of zone, lower boundary not observed, 5ACk horizon.

Grayish brown (2.5Y 5/2) silty clay loam, firm, structureless, many roots and rootlets, many humic materials, many insect burrows, very abrupt smooth lower boundary, $\mathrm{AC}$ horizon.

Gray (10YR 5/1) clay loam, firm, moderate medium angular blocky structure, many rootlets, many humic materials, common $\mathrm{CaCO}_{3}$ filaments and soft nodules, common insect burrows, abrupt smooth lower boundary, 2Abk horizon.

Grayish brown (2.5Y 5/2) clay loam, firm, structureless, common sand-filled insect burrows, many humic materials, common rootlets, few charcoal flecks, common $\mathrm{CaCO}_{3}$ filaments and nodules, clear smooth lower boundary, $2 \mathrm{ACk}$ horizon. 


$\begin{array}{cr}\text { Zone } & \text { Depth (cm) } \\ 4 & 81-113 \\ 5 & 113-120 \\ & \\ 6 & 120-156 \\ 7 & 156-169 \\ 7 & \\ 8 & 169-222 \\ 9 & 222-225+\end{array}$

Geomorphic Locality No. 1

$1 \quad 0-7$

2

$7-32+$

\section{Description}

Light grayish brown (2.5Y 6/2) silty clay, friable, massive, common distinct medium mottles (10YR 3/3), common $\mathrm{CaCO}_{3}$ nodules and filaments, few rootlets, common humic materials, common insect burrows, few sand-filled voids, abrupt smooth lower boundary, $2 \mathrm{Ck}$ horizon.

Grayish brown (2.5Y 5/2) silty clay loam, friable, structureless, few $\mathrm{CaCO}_{3}$ nodules, many humic materials, few insect burrows, thin $(1 \mathrm{~cm})$ organic-rich lens at top of zone, thin $(<1 \mathrm{~cm})$ sand lens at bottom of zone, very abrupt smooth lower boundary, 3AC horizon.

Grayish brown (2.5Y 5/2) silty clay loam, friable, structureless, common $\mathrm{CaCO}_{3}$ nodules, many humic materials, common insect burrows, thin $(2 \mathrm{~cm})$ organic-rich lens at $133 \mathrm{~cm}$, abrupt smooth lower boundary, 4ACk horizon.

Light brownish gray (2.5Y 6/2) silty clay loam, friable, structureless, common insect burrows, many humic materials in upper half of zone, common $\mathrm{CaCO}_{3}$ nodules, abrupt smooth lower boundary, $5 \mathrm{ACk}$ horizon.

Light brownish gray (10YR 6/2) silty clay loam, friable, structureless with common thin sandy lenses, many humic materials, few $\mathrm{CaCO}_{3}$ nodules, few rootlets, few insect burrows, clear smooth lower boundary, $6 \mathrm{AC}$ horizon.

Dark grayish brown (2.5Y 4/2) silty clay, friable, massive, common $\mathrm{CaCO}_{3}$ nodules, common humic materials, lower boundary not observed, $6 \mathrm{Ck}$ horizon.

Interbedded very pale brown (10YR 7/3) to pale brown (10YR 6/3) sand and grayish brown (2.5Y 5/2) mud ripples, very abrupt smooth to wavy lower boundary, $\mathrm{C}$ horizon.

Brown (7.5YR 5/4) clay loam, firm, strong coarse subangular blocky structure, few slickensides, common grayish brown (10YR 5/2) distinct coarse sandy mud mottles, common krotovina, common incipient soft $\mathrm{CaCO}_{3}$ nodules, few $\mathrm{CaCO}_{3}$ filaments, few humic materials, common gypsum crystals $(<2 \mathrm{~cm})$, lower boundary not observed, 2 Cox horizon. 


\section{REFERENCES CITED}

Bettis, E. Arthur, III

1984 New Conventions for the Designation of Soil Horizons and Layers. Plains Anthropologist 29(103):57-59.

Birkeland, Peter W.

1984 Soils and Geomorphology. Oxford University Press, Oxford.
Buol, S. W., F. D. Hole, and R. J. McCracken

1980 Soil Genesis and Classification. 2nd edition. Iowa State University Press, Ames. 
APPENDIX B: Textural and Chemical Analyses

of Sediment Samples, 41WY50

Karl W. Kibler 
Thirty-five sediment samples from site 41 WY50 were submitted to the Soils and Physical Geography Laboratory, Department of Geography, University of Wisconsin-Milwaukee, for grain-size analysis. Grain sizes were measured by hydrometer and sieve analysis at 1-phi intervals. Five of the 35 samples also were analyzed for soluble salts (Table 6). The numbers in Table 6 express a measure of electrical conductivity (millisiemens) per centimeter - the higher the number the higher the soluble salt content of the sample.

The determination of clastic sediment sizes is based on the Wentworth scale (Wentworth 1922). This scale uses millimeters to determine class size and divisions; for example, the lower size limit of sand is $0.0625 \mathrm{~mm}$ (fine sand), while the upper size limit is $2 \mathrm{~mm}$ (very coarse sand). This scale can be converted to a logarithmic scale (e.g., Krumbein 1934), which is known as the phi scale. Thus, a phi value of zero equals $1 \mathrm{~mm},-1$ phi equals $2 \mathrm{~mm}, 1$ phi equals $0.5 \mathrm{~mm}$, and so on. The use of the logarithmic ratio scales for grain sizes results in more-normally distributed sediment populations.

The results of the hydrometer and sieve

\begin{tabular}{|l|c|}
\hline \multicolumn{2}{|c|}{ TABLE 6 } \\
RESULTS OF SOLUBLE SALTS \\
ANALYSIS, 41WY50 \\
\hline \multicolumn{2}{|c|}{} \\
Provenience & $\begin{array}{c}\text { Soluble Salts } \\
\text { (millisiemens/cm) }\end{array}$ \\
\hline Backhoe Trench 2, & 1.70 \\
$46-51 \mathrm{~cm}$ & 0.62 \\
$165-170 \mathrm{~cm}$ & 0.97 \\
Backhoe Trench 11 & 0.45 \\
Locality 11a, 38-43 cm & 0.77 \\
Locality 11b, 26-30 cm & Locality 11c, 50-54 cm \\
\hline
\end{tabular}

analyses produced two sets of data that have been combined in Table 7. The hydrometer analysis separated grain sizes smaller than sand (4 phi) at 1phi intervals, while the sieve analysis separated the sand fraction (particles coarser than 4 phi) at the same interval. The textural boundaries utilized in this analysis in terms of the phi scale are given in Table 7. The textural phi values are percentages based on weight.

\section{REFERENCES}

Krumbien, W. C.

1934 Size Frequency Distributions of Sediments. Journal of Sedimentary Petrology 4:65-77.
Wentworth, C. K.

1922 A Scale of Grade and Class Terms for Clastic Sediments. Journal of Geology 30:377-392. 


\begin{tabular}{|c|c|c|c|c|c|c|c|c|c|c|c|}
\hline \multirow{2}{*}{ Sample Provenience } & \multicolumn{9}{|c|}{$\begin{array}{c}\text { TABLE } 7 \\
\text { RESULTS OF SEDIMENT GRAIN-SIZE ANALYSIS, 41WY50 }\end{array}$} & & \\
\hline & \multicolumn{5}{|c|}{ Sand } & \multicolumn{4}{|c|}{ Silt } & \multicolumn{2}{|c|}{ Clay } \\
\hline $\begin{array}{l}\text { Backhoe Trench } 2 \\
\text { Clay dune, } 0-4 \mathrm{~cm} \\
\text { Clay dune, } 20-25 \mathrm{~cm} \\
\text { Clay dune, } 46-51 \mathrm{~cm} \\
\text { Clay dune, } 82-87 \mathrm{~cm} \\
\text { Clay dune, } 97-102 \mathrm{~cm} \\
\text { Clay dune, } 110-116 \mathrm{~cm} \\
\text { Clay dune, } 133-138 \mathrm{~cm} \\
\text { Clay dune, } 148-153 \mathrm{~cm} \\
\text { Clay dune, } 165-170 \mathrm{~cm}\end{array}$ & $\begin{array}{l}0.14 \\
0.16 \\
0.00 \\
0.00 \\
0.00 \\
0.00 \\
0.00 \\
0.00 \\
0.15\end{array}$ & $\begin{array}{l}0.14 \\
0.16 \\
0.15 \\
0.16 \\
0.16 \\
0.17 \\
0.18 \\
0.17 \\
0.15 \\
\end{array}$ & $\begin{array}{l}1.80 \\
3.01 \\
1.57 \\
1.44 \\
1.06 \\
2.61 \\
2.00 \\
0.76 \\
0.87\end{array}$ & $\begin{array}{l}30.24 \\
21.46 \\
17.25 \\
17.47 \\
14.40 \\
21.26 \\
23.20 \\
12.44 \\
17.73 \\
\end{array}$ & $\begin{array}{l}28.43 \\
20.58 \\
17.94 \\
26.30 \\
28.99 \\
19.03 \\
30.00 \\
22.00 \\
24.16 \\
\end{array}$ & $\begin{array}{l}8.46 \\
5.38 \\
4.62 \\
5.38 \\
8.46 \\
3.85 \\
0.00 \\
8.46 \\
7.69 \\
\end{array}$ & $\begin{array}{r}4.62 \\
3.08 \\
3.08 \\
10.00 \\
3.08 \\
1.54 \\
3.08 \\
3.08 \\
3.85 \\
\end{array}$ & $\begin{array}{l}3.08 \\
3.08 \\
3.08 \\
1.54 \\
3.08 \\
3.08 \\
3.08 \\
3.85 \\
4.62 \\
\end{array}$ & $\begin{array}{l}4.62 \\
6.15 \\
5.38 \\
0.77 \\
3.85 \\
4.62 \\
5.38 \\
6.15 \\
3.85 \\
\end{array}$ & $\begin{array}{l}3.08 \\
6.15 \\
4.62 \\
1.54 \\
3.85 \\
5.38 \\
3.08 \\
4.62 \\
3.08 \\
\end{array}$ & $\begin{array}{l}15.38 \\
30.77 \\
42.31 \\
35.38 \\
33.08 \\
38.46 \\
30.00 \\
38.46 \\
33.85\end{array}$ \\
\hline $\begin{array}{l}\text { Backhoe Trench Locality 11a } \\
\text { Slopewash, } 0-4 \mathrm{~cm} \\
\text { Clay dune, } 17-23 \mathrm{~cm} \\
\text { Clay dune, } 29-33 \mathrm{~cm} \\
\text { Clay dune, } 38-43 \mathrm{~cm} \\
\text { Clay dune, } 56-60 \mathrm{~cm} \\
\text { Clay dune, } 73-78 \mathrm{~cm} \\
\text { Clay dune, } 89-93 \mathrm{~cm} \\
\text { Clay dune, } 108-113 \mathrm{~cm} \\
\end{array}$ & $\begin{array}{l}0.16 \\
0.14 \\
0.17 \\
0.17 \\
0.17 \\
0.17 \\
0.00 \\
0.16 \\
\end{array}$ & $\begin{array}{l}0.16 \\
0.14 \\
0.17 \\
0.17 \\
0.17 \\
0.17 \\
0.16 \\
0.18 \\
\end{array}$ & $\begin{array}{l}2.29 \\
1.41 \\
1.73 \\
1.42 \\
2.25 \\
2.30 \\
1.84 \\
0.55 \\
\end{array}$ & $\begin{array}{l}26.56 \\
21.01 \\
19.25 \\
22.01 \\
20.65 \\
17.71 \\
20.59 \\
13.79 \\
\end{array}$ & $\begin{array}{l}32.37 \\
19.60 \\
23.30 \\
22.36 \\
15.21 \\
12.71 \\
18.94 \\
26.84 \\
\end{array}$ & $\begin{array}{r}10.77 \\
10.00 \\
7.69 \\
7.69 \\
8.46 \\
6.15 \\
6.15 \\
7.69 \\
\end{array}$ & $\begin{array}{l}5.38 \\
4.62 \\
3.08 \\
2.31 \\
5.38 \\
4.62 \\
2.31 \\
3.08 \\
\end{array}$ & $\begin{array}{l}3.85 \\
4.62 \\
4.62 \\
3.85 \\
5.38 \\
3.85 \\
3.85 \\
5.38 \\
\end{array}$ & $\begin{array}{l}3.08 \\
4.62 \\
2.31 \\
3.85 \\
6.92 \\
1.54 \\
0.77 \\
1.54\end{array}$ & $\begin{array}{r}2.31 \\
4.62 \\
6.92 \\
4.62 \\
6.15 \\
10.77 \\
7.69 \\
26.92\end{array}$ & $\begin{array}{l}13.08 \\
29.23 \\
30.77 \\
31.54 \\
29.23 \\
40.00 \\
37.69 \\
13.85\end{array}$ \\
\hline $\begin{array}{l}\text { Backhoe Trench Locality 11b } \\
\text { Slopewash, } 8-13 \mathrm{~cm} \\
\text { Clay dune, } 18-21 \mathrm{~cm} \\
\text { Clay dune, } 26-30 \mathrm{~cm} \\
\text { Clay dune, } 43-48 \mathrm{~cm} \\
\text { Clay dune, } 57-62 \mathrm{~cm} \\
\text { Clay dune, } 73-78 \mathrm{~cm}\end{array}$ & $\begin{array}{l}0.17 \\
0.00 \\
0.15 \\
0.14 \\
0.17 \\
0.17\end{array}$ & $\begin{array}{l}0.17 \\
0.15 \\
0.15 \\
0.14 \\
0.19 \\
0.34\end{array}$ & $\begin{array}{l}3.42 \\
1.53 \\
3.82 \\
2.73 \\
1.92 \\
2.91\end{array}$ & $\begin{array}{l}26.78 \\
26.51 \\
29.92 \\
26.97 \\
17.31 \\
18.71\end{array}$ & $\begin{array}{l}27.92 \\
27.18 \\
27.48 \\
22.31 \\
25.01 \\
20.94\end{array}$ & $\begin{array}{r}7.69 \\
6.92 \\
8.46 \\
10.77 \\
10.77 \\
15.38\end{array}$ & $\begin{array}{l}3.08 \\
2.31 \\
3.85 \\
3.08 \\
3.85 \\
6.15\end{array}$ & $\begin{array}{l}3.08 \\
2.31 \\
2.31 \\
3.08 \\
2.31 \\
3.85\end{array}$ & $\begin{array}{l}3.08 \\
2.31 \\
1.54 \\
3.08 \\
6.15 \\
4.62\end{array}$ & $\begin{array}{l}3.08 \\
5.38 \\
1.54 \\
3.08 \\
6.15 \\
4.62\end{array}$ & $\begin{array}{l}21.54 \\
25.38 \\
20.77 \\
24.62 \\
26.15 \\
22.31\end{array}$ \\
\hline
\end{tabular}




\begin{tabular}{|c|c|c|c|c|c|c|c|c|c|c|c|}
\hline \multicolumn{12}{|l|}{ Table 7, continued } \\
\hline \multirow[b]{2}{*}{ Sample Provenience } & \multicolumn{5}{|c|}{ Sand } & \multicolumn{4}{|c|}{ Silt } & \multicolumn{2}{|c|}{ Clay } \\
\hline & 0 phi & 1 phi & 2 phi & 3 phi & 4 phi & 5 phi & 6 phi & $7 \mathrm{phi}$ & $8 \mathrm{phi}$ & 9 phi & $<9$ phi \\
\hline $\begin{array}{l}\text { Backhoe Trench Locality 11c } \\
\text { Slopewash, } 11-15 \mathrm{~cm} \\
\text { Wind-tidal flat, } 21-26 \mathrm{~cm} \\
\text { Clay dune, } 30-35 \mathrm{~cm} \\
\text { Clay dune, } 50-54 \mathrm{~cm} \\
\text { Clay dune, } 59-63 \mathrm{~cm} \\
\text { Clay dune, } 68-72 \mathrm{~cm} \\
\text { Beaumont Formation, } 76-81 \mathrm{~cm}\end{array}$ & $\begin{array}{l}0.14 \\
0.21 \\
0.38 \\
0.15 \\
0.13 \\
0.53 \\
0.29\end{array}$ & $\begin{array}{l}0.31 \\
0.42 \\
0.57 \\
0.35 \\
0.15 \\
0.53 \\
0.59\end{array}$ & $\begin{array}{l}4.70 \\
2.31 \\
1.93 \\
2.11 \\
1.81 \\
2.29 \\
2.08\end{array}$ & $\begin{array}{l}31.38 \\
14.08 \\
12.76 \\
19.89 \\
20.62 \\
21.01 \\
18.77\end{array}$ & $\begin{array}{l}18.82 \\
16.82 \\
18.18 \\
19.01 \\
18.04 \\
21.01 \\
15.94\end{array}$ & $\begin{array}{r}8.46 \\
13.08 \\
9.23 \\
8.46 \\
8.46 \\
10.00 \\
14.62\end{array}$ & $\begin{array}{l}2.31 \\
6.15 \\
4.62 \\
4.62 \\
3.08 \\
6.15 \\
6.15\end{array}$ & $\begin{array}{l}3.08 \\
5.38 \\
3.85 \\
2.31 \\
2.31 \\
2.31 \\
3.08\end{array}$ & $\begin{array}{l}3.08 \\
5.38 \\
6.15 \\
4.62 \\
3.85 \\
4.62 \\
4.62\end{array}$ & $\begin{array}{r}4.62 \\
20.00 \\
13.08 \\
9.23 \\
6.15 \\
3.85 \\
3.85\end{array}$ & $\begin{array}{l}23.08 \\
16.15 \\
29.23 \\
29.23 \\
35.38 \\
27.69 \\
30.00\end{array}$ \\
\hline $\begin{array}{l}\text { Backhoe Trench Locality } 11 \mathrm{~d} \\
\text { Wind-tidal flat, } 0.97-1.03 \mathrm{~m} \\
\text { Wind-tidal flat, } 0.73-0.77 \mathrm{~m} \\
\text { Wind-tidal flat, } 0.59-0.65 \mathrm{~m} \\
\text { Wind-tidal flat, } 0.44-0.48 \mathrm{~m} \\
\text { Wind-tidal flat, } 0.28-0.34 \mathrm{~m}\end{array}$ & $\begin{array}{l}0.14 \\
0.13 \\
0.14 \\
0.15 \\
0.31\end{array}$ & $\begin{array}{l}0.14 \\
0.13 \\
0.15 \\
0.91 \\
0.78\end{array}$ & $\begin{array}{r}2.85 \\
8.63 \\
5.89 \\
24.49 \\
4.54\end{array}$ & $\begin{array}{l}26.81 \\
47.53 \\
37.96 \\
49.59 \\
30.37\end{array}$ & $\begin{array}{r}23.12 \\
17.41 \\
23.54 \\
6.39 \\
17.84\end{array}$ & $\begin{array}{l}6.15 \\
4.62 \\
6.92 \\
1.54 \\
7.69\end{array}$ & $\begin{array}{l}3.85 \\
1.54 \\
2.31 \\
1.54 \\
4.62\end{array}$ & $\begin{array}{l}2.31 \\
0.77 \\
1.54 \\
1.54 \\
3.08\end{array}$ & $\begin{array}{l}4.62 \\
2.31 \\
2.31 \\
1.54 \\
3.08\end{array}$ & $\begin{array}{l}3.85 \\
2.31 \\
3.08 \\
1.54 \\
3.08\end{array}$ & $\begin{array}{l}26.15 \\
14.62 \\
16.15 \\
10.77 \\
24.62\end{array}$ \\
\hline
\end{tabular}



APPENDIX C: Analysis of Vertebrate Remains from 41 WY50 and 41 WY60

James W. Westgate

Department of Geology

Lamar University

Beaumont, Texas 



\section{INTRODUCTION}

The archeological excavations at two Willacy County clay dune sites, 41WY50 and 41WY60, yielded 286 vertebrate specimens. Approximately $27 \%(\mathrm{n}=77)$ are not identifiable beyond their recognition as vertebrate remains. The other $73 \%$ are identified at least to the level of Class. The specimens were identified in the Paleontology Laboratory of the Department of Geology at Lamar University using comparative materials from the recent vertebrate collections of the Departments of Geology and Biology. All of the remains appear to represent species currently inhabiting Willacy County. A possible exception is the phalanx from a bovid which does not allow differentiation between that of a bison or a domestic form of cattle.

\section{RESULTS}

Table 8 is a composite faunal list which includes scientific and common names and the prefer- red Texas habitats of the species whose remains were collected from the two sites. The aquatic species prefer estuarine or freshwater habitats such as the nearby Laguna Madre and its tributaries. Terrestrial forms identified at the species level include the Texas gopher tortoise, the southern plains woodrat, and the hispid pocket mouse. Coastal populations of the first two species are restricted today to south Texas, while the hispid pocket mouse range extends southward from Galveston Bay (Pritchard 1979; Schmidly 1983).

Tables 9 and 10 are itemized lists of the vertebrate remains recovered from each site presented by test unit and level. The specimens are identified to taxon, element, number, side, and minimum number of individuals. Several mammalian specimens are identified as being from small (mouse to rabbit) or medium (fox to deer) sized species. Most of the remains identified as chelonian are probably from the Texas gopher tortoise. There is no obvious indication of seasonality represented by the faunal remains, although thin sections of the three otoliths could provide additional information. 
TABLE 8

COMPOSITE FAUNAL LIST AND PREFERRED TEXAS HABITATS

\begin{tabular}{|c|c|c|}
\hline Scientific Name & Common Name & Preferred Habitats \\
\hline Osteichthyes & bony fishes & \\
\hline Holostei & gar, bowfin & \\
\hline Lepisosteus sp. & gar & freshwater, estuarine, nearshore \\
\hline Teleostei & advanced rayfin fishes & \\
\hline Ariidae & sea catfishes & \\
\hline Arius felis & hardhead catfish & estuarine, nearshore \\
\hline Sparidae & porgies & \\
\hline Archosargus probatocephalus & sheepshead & estuarine, nearshore \\
\hline Scianidae & croakers & \\
\hline Cynoscion sp. & seatrout & estuarine, inner shelf \\
\hline Pogonias cromis & black drum & estuarine \\
\hline Amphibia & frogs, salamanders & \\
\hline Anura & frogs, toads & freshwater, terrestrial arboreal \\
\hline Reptilia & reptiles & \\
\hline Chelonia & turtles & \\
\hline Gopherus berlandieri & Texas gopher tortoise & south Texas brushy semidesert \\
\hline Ophidia & snakes & \\
\hline Colubridae & common snakes & cosmopolitan \\
\hline Aves & birds & \\
\hline Mammalia & mammals & \\
\hline Bovidae & cattle, bison & \\
\hline Rodentia & rodents & \\
\hline Perognathus hispidus & hispid pocket mouse & open sandy fields with scattered trees \\
\hline Neotoma micropus & southem plains woodrat & semiarid-xeric, mesquite and cacti thickets \\
\hline
\end{tabular}




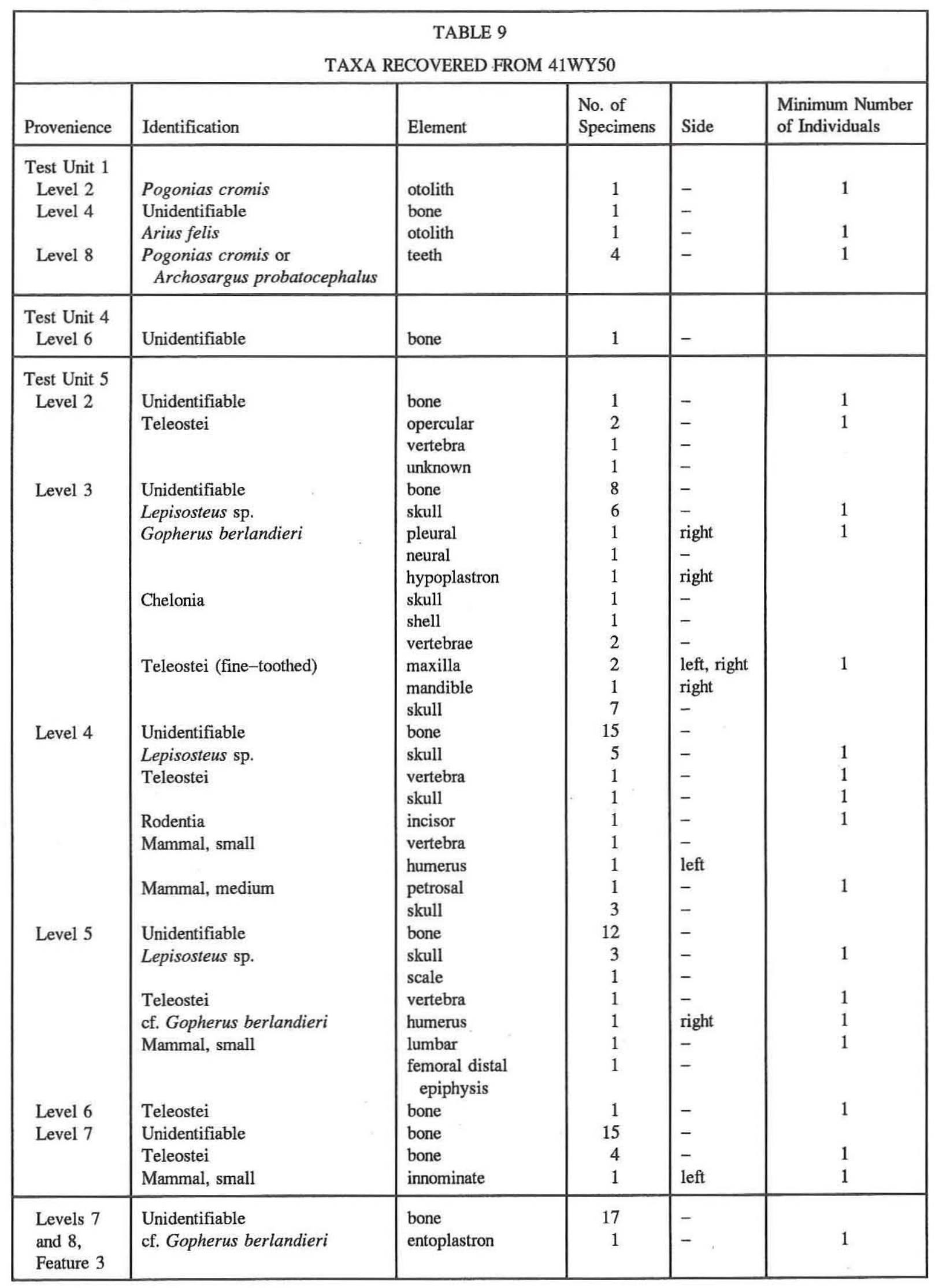




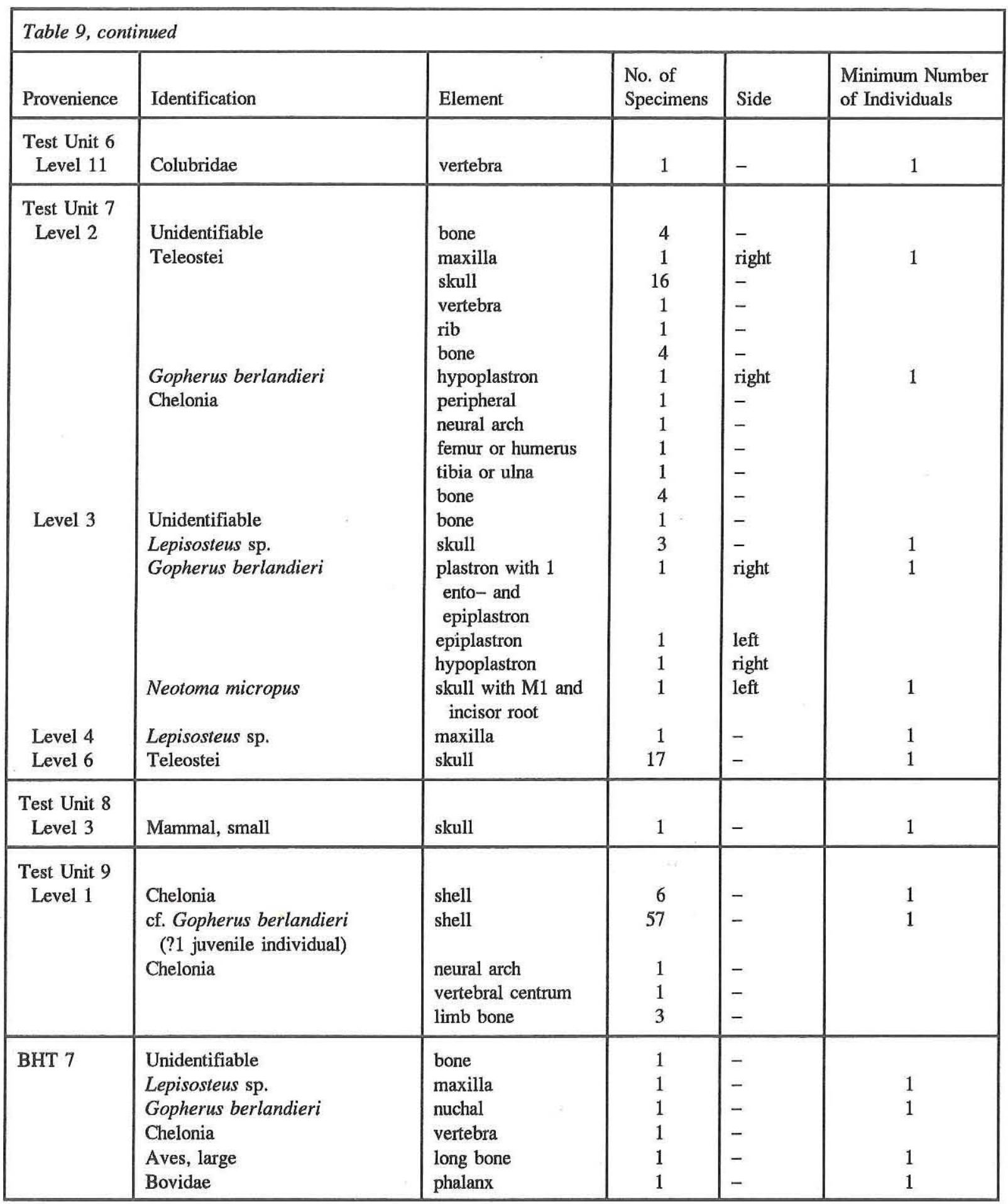


Appendix C: Analysis of Vertebrate Remains from 41 WY50 and 41 WY60

\begin{tabular}{|c|c|c|c|c|c|}
\hline \multicolumn{6}{|c|}{$\begin{array}{c}\text { TABLE } 10 \\
\text { TAXA RECOVERED FROM } 41 \text { WY } 60\end{array}$} \\
\hline Provenience & Identification & Element & $\begin{array}{l}\text { No. of } \\
\text { Specimens }\end{array}$ & Side & $\begin{array}{l}\text { Minimum Number } \\
\text { of Individuals }\end{array}$ \\
\hline $\begin{array}{l}\text { Test Unit } 1 \\
\text { Level } 3 \\
\text { Level } 5\end{array}$ & $\begin{array}{l}\text { Cynoscion } \text { sp. } \\
\text { Mollusca, bivalvia }\end{array}$ & $\begin{array}{l}\text { otolith } \\
\text { shell }\end{array}$ & $\begin{array}{l}1 \\
1\end{array}$ & - & $\begin{array}{l}1 \\
1\end{array}$ \\
\hline $\begin{array}{l}\text { Test Unit } 2 \\
\text { Level } 2\end{array}$ & $\begin{array}{l}\text { Unidentifiable } \\
\text { Neotoma micropus } \\
\text { Anura } \\
\text { Aves, small } \\
\text { Rodentia }\end{array}$ & $\begin{array}{l}\text { bone } \\
\text { mandible with M2 } \\
\text { lumbar } \\
\text { carpo-metacarpal } \\
\text { incisor }\end{array}$ & $\begin{array}{l}1 \\
1 \\
1 \\
1 \\
1\end{array}$ & $\begin{array}{l}\text { - } \\
\text { right } \\
- \\
- \\
-\end{array}$ & $\begin{array}{l}1 \\
1 \\
1 \\
1\end{array}$ \\
\hline $\begin{array}{l}\text { Test Unit } 3 \\
\text { Level } 3\end{array}$ & Crustacea, Decapoda & claw & 2 & - & 1 \\
\hline $\begin{array}{l}\text { Test Unit } 5 \\
\text { Level } 2 \\
\text { Level } 3\end{array}$ & $\begin{array}{l}\text { Teleostei } \\
\text { Teleostei }\end{array}$ & $\begin{array}{l}\text { vertebra } \\
\text { skull } \\
\text { vertebra } \\
\text { opercular }\end{array}$ & $\begin{array}{l}1 \\
2 \\
1 \\
1\end{array}$ & $\begin{array}{l}- \\
\overline{-} \\
\overline{\text { left }}\end{array}$ & $\begin{array}{l}1 \\
1 \\
1\end{array}$ \\
\hline $\begin{array}{l}\text { Test Unit } 6 \\
\text { Level } 3 \\
\text { Level } 5\end{array}$ & $\begin{array}{l}\text { Anura } \\
\text { Perognathus hispidus }\end{array}$ & $\begin{array}{l}\text { lumbar } \\
\text { mandible with incisor and } \mathrm{P} 4\end{array}$ & $\begin{array}{l}1 \\
1\end{array}$ & $\overline{\text { left }}$ & $\begin{array}{l}1 \\
1\end{array}$ \\
\hline
\end{tabular}

\section{REFERENCES CITED}

Pritchard, Peter C. H.

1979 Encyclopedia of Turtles. T.F.H. Publishing Co., Neptune, New Jersey.
Schmidly, D. J.

1983 Texas Mammals East of the Balcones Fault Zone. Texas A\&M University Press, College Station. 



\title{
APPENDIX D: Pollen and Phytolith Analyses
}

\author{
J. Philip Dering
}

\author{
Palynology Laboratory \\ Department of Anthropology \\ Texas A\&M University \\ College Station, Texas
}





\section{INTRODUCTION}

Three samples of sediment and feature fill (Features 3 and 10) from site 41WY50 were processed and analyzed for their pollen and phytolith content. The following presents the methods and results of the analysis, and recommendations for future palynological research in the region.

\section{METHODS}

The samples were processed according to standard palynological procedures as follows: (1) $25 \mathrm{ml}$ of each sample was measured into a $600-\mathrm{ml}$ beaker; (2) two Lycopodium tablets $(11,300 \pm 500$ spores each) were added to each sample; (3) each sample was treated with $10 \% \mathrm{HCl}$ to dissolve carbonates; (4) the samples were passed through a 150-micron mesh to remove larger objects; (5) a swirl-and-pour technique was utilized to remove other large sediments; (6) the samples were acetylated to remove organic materials; (7) a heavy-density method, using $\mathrm{ZNBr}^{2}$ at a specific gravity of 2.35 , was utilized to separate the lighter pollen and phytoliths from heavier sediments, completing the processing; and finally, (8) the samples were transferred to glycerine and stored in 1 -dram vials.

The Lycopodium tablets were added to monitor the extraction process for losses and to determine the concentration of fossil palynomorphs in the sediments. The samples were observed using a JENA binocular microscope.

\section{RESULTS AND DISCUSSION}

Examination of the three samples indicated that no fossil pollen is present in the sediments or feature fill. A few club-shaped phytoliths were observed, but there is not enough material to warrant further analysis.

The poor preservation is typical of the very alkaline sediments and high oxidation rates present in south Texas. High temperatures and repeated wet-dry cycles that occur in the region also contribute to the destruction of palynomorphs. Each time the soil hydration-dehydration process occurs, the pollen trapped in the soil is subjected to two potentially destructive processes: (1) the expansion-contraction process caused by being wetted and dried; and (2) the pressure phenomenon described by Burstyn and Bartlett (1975). The more frequently this cycle occurs in a soil, the greater the potential for fossil pollen to be destroyed or deteriorated, first by developing stress cracks in the exine and next by further breakdown of the pollen wall by mechanical processes.

These conditions combine to destroy pollen grains which are normally highly durable in many sedimentary samples (Hall 1981; Havinga 1964). As a result, paleobotanical research in the south Texas region has produced few significant records of Quaternary-age vegetation and has contributed little to the paleoenvironmental reconstruction of that area (Dering and Bryant 1993).

\section{RECOMMENDATIONS FOR FUTURE INVESTIGATIONS}

The results of the analysis of pollen samples from 41WY50, combined with the results of many other attempts to extract pollen from sediments in south Texas (Dering and Bryant 1994), indicate that pollen preservation in the south Texas region is very poor. This does not rule out the possibility that fossil pollen can be recovered from archeological sites in south Texas. Continued testing for the presence of pollen would be recommended in specific cases where microenvironments would be favorable for the preservation of pollen. For example, King et al. (1975) found excellent preservation in specific microenvironments at the Rhoades Site in eastern North America, even though the general preservational environment was poor. Excellent pollen recovery was obtained from archeological features, especially in association with copper artifacts and tree bark. King et al. (1975) recommended that there is a need for a strategy that includes sampling areas of a site that may be best for pollen preservation. If adequate pollen preservation is present at south Texas sites, it probably will be a specific microenvironment, most likely an archeological feature with a comparatively sealed context such as the remnants of a structure or a cooking or temporary storage area. If one of these favorable environments is not found, it is doubtful that adequate pollen recovery can be obtained from other samples at the site. 


\section{REFERENCES CITED}

Burstyn, H. P., and A. A. Bartlett

1975 Critical Point Drying: Application of the Physics of the PVT Surface to Electron Microscopy. American Journal of Physics 43:414-419.

Dering, J. Phil, and Vaughn M. Bryant, Jr.

1994 Plant Remains from the Applewhite Terrace: Implications for Holocene Climatic Change in South-Central Texas. Occasional Papers. The Museum, Texas Tech University, Lubbock.

Hall, Stephen A.

1981 Deteriorated Pollen Grains and the Interpreta- tion of Quaternary Pollen Diagrams. Review of Paleobotany and Palynology 32:193-206.

Havinga, A. J.

1964 Investigations into the Differential Corrosion Susceptibility of Pollen and Spores. Pollen et Spores 6:621-635.

King, James E., Walter E. Klippel, and Rose Duffield 1975 Pollen Preservation and Archeology in Eastern North America. American Antiquity 40(2):180190. 


\title{
APPENDIX E: Micromorphological Analysis of Features, 41 WY50
}

\author{
Karl W. Kibler
}

and

Paul Goldberg

Texas Archeological Research Laboratory

The University of Texas at Austin 

Micromorphology involves the study of undisturbed soils and sediments at a microscopic scale. It is a technique to aid in the identification and interpretation of the geomorphic and anthropogenic processes affecting archeological site formation. Commonly this technique involves the use of thin sections - a 25-30-micron-thick slice of soil and sediment mounted on a glass slide. The procedures for collecting the samples, impregnating them, cutting them into thin sections, and mounting them are discussed in detail by Courty et al. (1989).

Two block samples of sediments and hearth features were collected from the profiles of test units or existing cross-section exposures for micromorphological analysis. The two samples were collected from Features 9 and 10 at site 41WY50. Both samples included feature fill (charcoal) and underlying and overlying sediments.

The Feature 9 sample revealed a thin $(1-2 \mathrm{~cm})$ layer of wood charcoal atop a zone of oxidized sediments, which clearly represents in situ burning (Figure 32). The sediments above and below the feature depict the poorly sorted deposits of very fine to fine quartz sand and clay pellets or aggregates. Bioturbation is limited throughout the

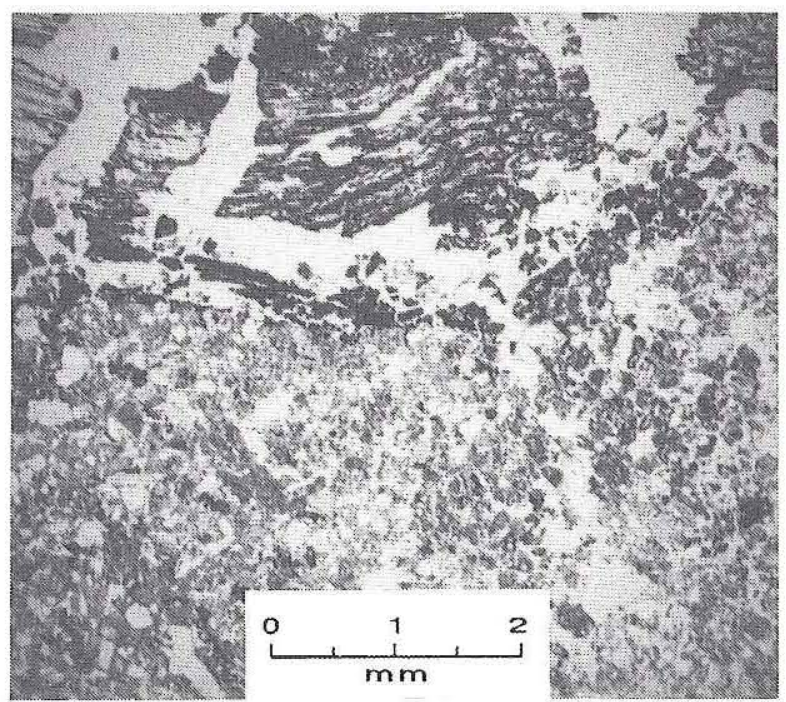

Figure 32. Thin section of Feature 9 sediments showing wood charcoal and underlying oxidized sediments. sample. Micro bedding structures, depicting the incremental accretion of the dune, consist of graded parallel laminations (3-6 mm thick). Weathering or surface stability is marked by zones of flocculated clay pellets, whereas zones of distinct pellets and quartz sand represent more-rapid depositional episodes.

The sample from Feature 10 revealed a thin (less than $1 \mathrm{~cm}$ ) layer of grass charcoal atop a zone of oxidized sediments (Figure 33). Grass silicas or phytoliths are abundantly revealed throughout the feature fill under polarized light. Tiny bone fragments are present in the overlying sediments but are not burned and probably are not associated with the feature. Micro bedding structures, similar to those observed in the Feature 9 sample, also were observed in the Feature 10 sample.

The identification of the oxidized sediments conclusively shows that the features represent in situ burning and not the decomposition of organic materials. The identification of grass used as a fuel in Feature 10 suggests that woody plant species made up a small percentage of the dune's plant community.

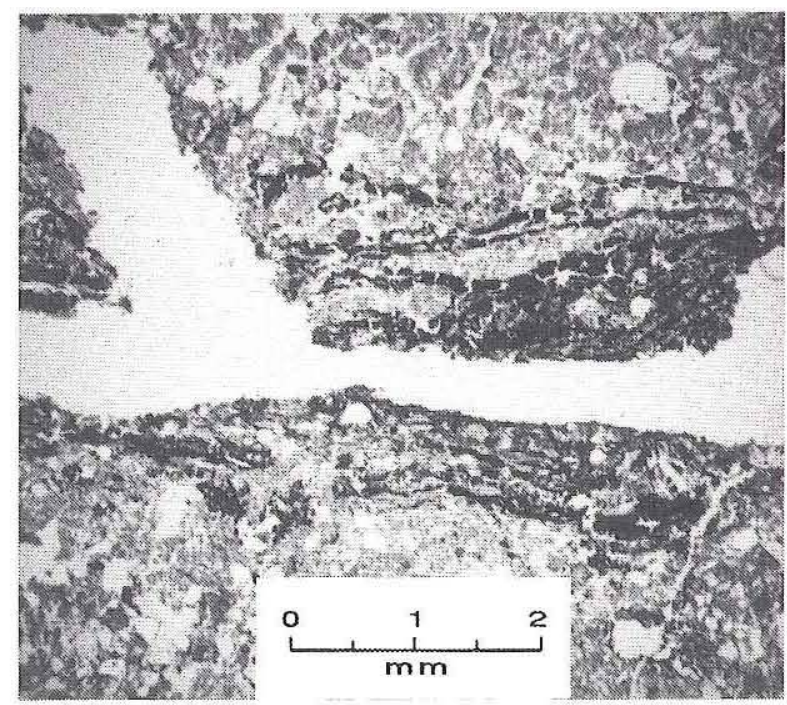

Figure 33. Thin section of Feature 10 sediments showing grass charcoal and underlying oxidized sediments.

\section{REFERENCE CITED}

Courty, Marie Agnes, Paul Goldberg, and Richard MacPhail

1989 Soils and Micromorphology in Archaeology. Cambridge University Press, Cambridge. 



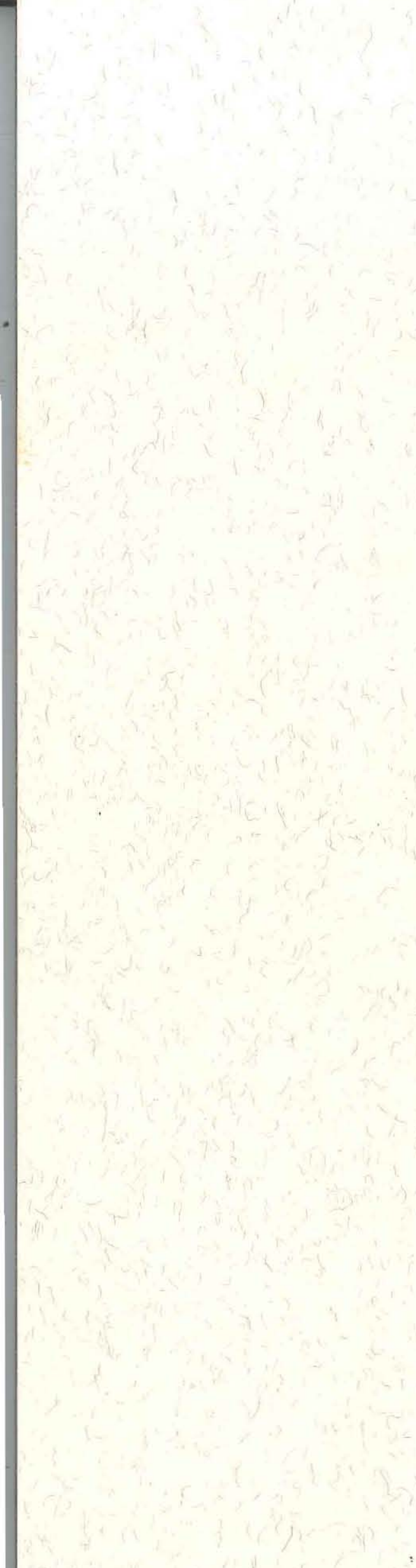

